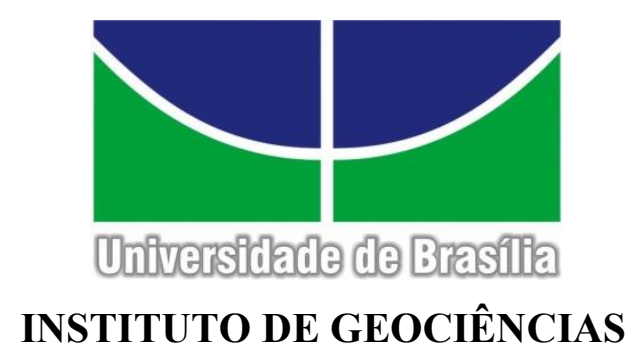

\title{
Sistema granítico - pegmatítico Mata Azul: Caracterização e Gênese
}

\author{
Tese de Doutorado
}

$\mathbf{N}^{0} 132$

Hudson de Almeida Queiroz

Orientador: Prof. Dr. Nilson Francisquini Botelho 


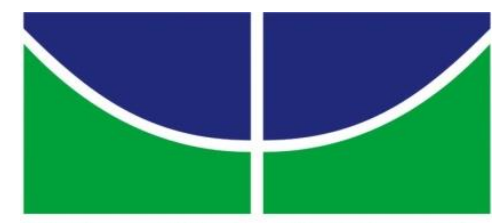 \\ Tonfuersidade do Brasilla \\ INSTITUTO DE GEOCIÊNCIAS}

\section{Sistema granítico - pegmatítico Mata Azul: \\ Caracterização e Gênese}

\section{Hudson de Almeida Queiroz}

Tese de doutorado elaborada junto ao Programa de Pós-Graduação em Geologia (Área de concentração Mineralogia e Petrologia), do Instituto de Geociências (IG) da Universidade de Brasília (UnB) para obtenção do Título de Doutor em geologia 


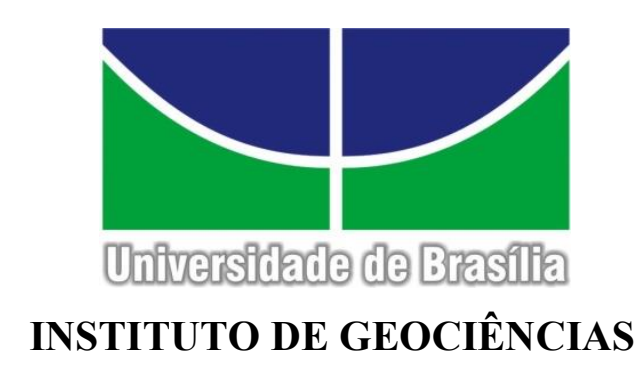

\title{
Sistema granítico - pegmatítico Mata Azul: Caracterização e Gênese
}

\section{Tese de Doutorado}

$\mathbf{N}^{\mathbf{0}} \mathbf{1 3 2}$

\author{
Hudson de Almeida Queiroz \\ Orientador: Prof. Dr. Nilson F. Botelho \\ Banca Examinadora: Prof ${ }^{a}$. Dr ${ }^{\mathrm{a}}$ Catarina L.B.Toledo (UnB) \\ Prof. Dr. Elton L. Dantas (UnB) \\ Prof. Dr. Hartmurt Beurlen (UFPE) \\ Prof. Dr. Ricardo A. Scholz Cipriano (UFOP)
}

Brasília, agosto de 2016 
Não há lugar para sabedoria onde não há paciência.

Santo Agostinho 
Agradecimentos

Agradeço a Deus.

Agradeço a orientação do professor Nilson, sempre disposto a dedicar parte do seu tempo para discutir e sanar dúvidas.

A minha família pelo apoio a esta escolha profissional.

Ao instituto de Geociências da UnB pela utilização dos laboratórios e auxílio dos técnicos dos laboratórios de microssonda, laminação e geocronologia. Aos colegas de pós-graduação pela idéias e discussões, assim como os professores José Oswaldo, Catarina, Valmir, Edí, Claudinei e Elton.

A CAPES pelo auxílio da bolsa de doutorado.

A professora Rúbia Viana por ter me introduzido aos pegmatitos de Tocantins.

Aos garimpeiros e ex-garimpeiros "João Preto", Domingos, Vivaldo e Cláudio pelo auxílio nos trabalhos de campo, sem o qual não seria possível conhecer todas as ocorrências estudadas nesta tese. 


\section{SUMÁRIO}

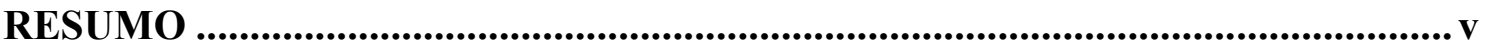

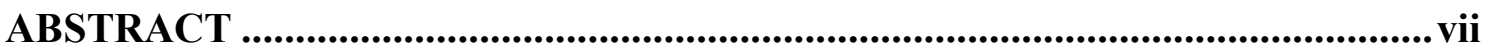

CAPÍTULO 1 - INTRODUÇÃO........................................................................2

1.1 APRESENTAÇÃO ...................................................................... 2

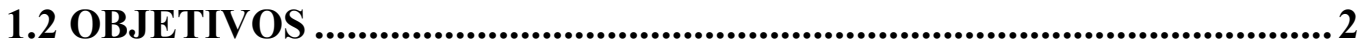

1.3 LOCALIZAÇÃO E VIAS DE ACESSO .................................................. 3

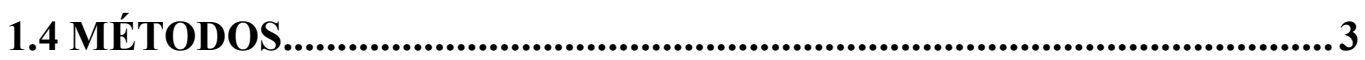

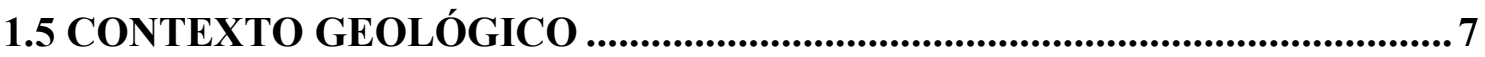

CAPÍTUlO 2 - The Mata Azul Pegmatitic Field, Tocantins/Goiás, central Brazil: geology, Genesis and mineralization. ..................................................................11

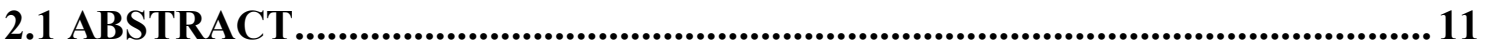

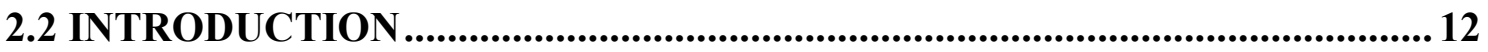

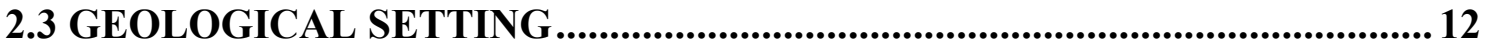

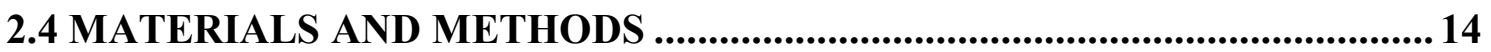

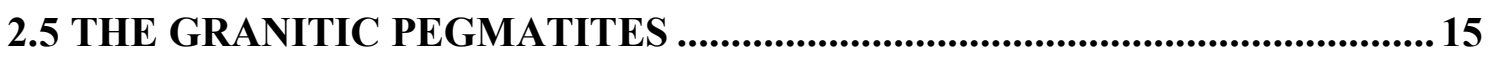

2.6 THE MATA AZUL SUITE AT LEVANTINA QUARRY .............................38

2.7 DISCUSSION AND THE MATA AZUL PEGMATITIC FIELD ....................43

CAPÍTULO 3 - Fosfatos de Fe-Mn primários e secundários em pegmatitos graníticos do campo pegmatítico mata azul, região central do brasil .....................52

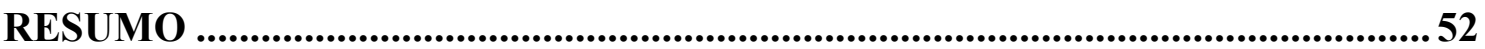

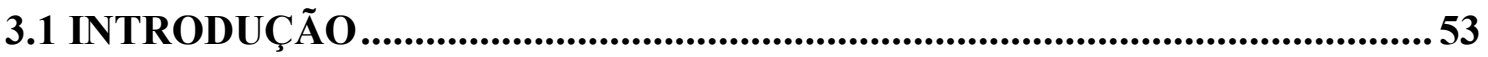

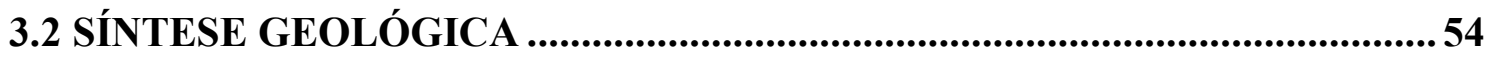

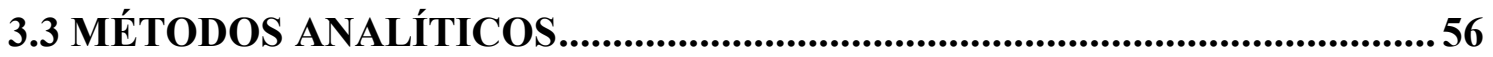

3.4 OS PEGMATITOS DO SUBTIPO BERILO-COLUMBITA-FOSFATO ........56

3.5 PETROGRAFIA DOS FOSFATOS ..............................................................58

3.6 DISCUSSÕES E SEQUENCIA DE ALTERAÇÃO ...................................... 64 


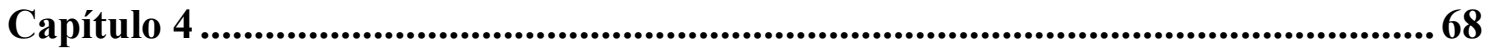

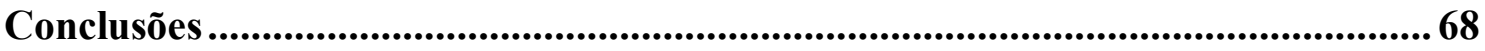

Referências Bibliográficas ..................................................................................... 72

ANEXOS 


\section{Lista de Figura e Tabelas}

\section{Capítulo 1}

Figura 1. 1: Mapa de localização ............................................................................ 4

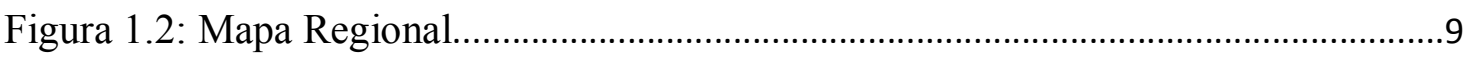

\section{Capítulo 2}

Figure 2. 1: Simplified map of the Tocantins Structural Province. .............................. 13

Figure 2. 2: Geological map with the studied points. ............................................... 17

Table 2. 1: List of minerals identified in pegmatites explored for beryl ...................... 19

Table 2. 2: Chemistry composition of minerals found in pegmatites explored for beryl19

Figure 2.3: Pegmatites explored for beryl............................................................ 20

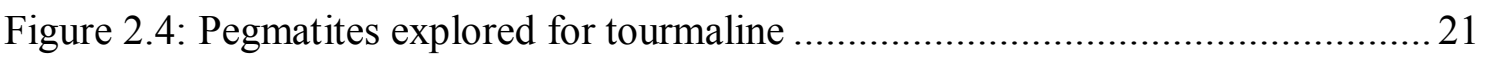

Figure 2. 5: Mica and tourmaline classification diagrams. ...................................... 23

Table 2. 3: Representative composition of tourmaline crystals...................................2 24

Table 2. 4: Representative composition of selected minerals from the pegmatites

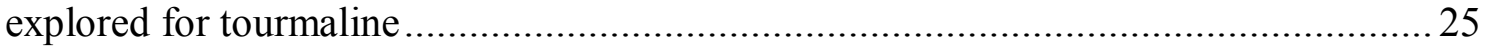

Table 2. 5: List of minerals found in the pegmatites explored for tourmaline...............2 25

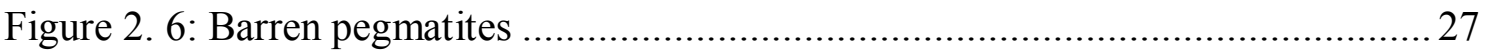

Figure 2. 7: Photomicrograph of dravite-bearing schist. ........................................ 29

Figure 2. 9: Element distribution (in apfu) in metasomatic phases............................. 31

Table 2. 6: Representative composition of metasomatic oxides. ................................ 32

Figure 2. 10: Chemical composition of garnet crystals ................................................ 33

Table 2. 7: Representative composition of some metasomatic minerals. ..................... 34

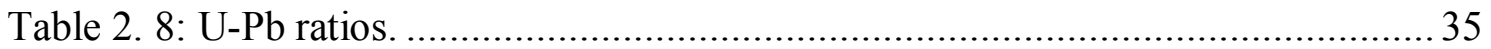

Figure 2. 11: U-Pb Concordia diagram of monazite.................................................. 36

Table 2. 9: $\mathrm{U}-\mathrm{Pb}$ values and the calculated age by the chemical dating. ........................ 37

Figure 2. 12: Frequency histogram of the calculated uraninite ages. ........................ 38

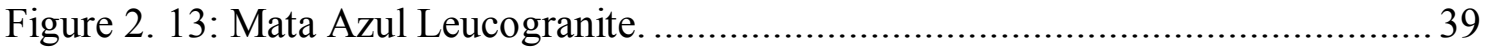

Table 2. 10: Chemical composition of coarse grain leucogranites. ............................. 40

Figure 2. 14: Tectonic setting of Mata Azul leucogranite ....................................... 42

Figure 2. 15: Chondrite-normalized REE patterns. ................................................. 42

Figure 2. 16: Schematic representation of pegmatite regional zoning and evolution .... 44

Figure 2. 17: Roof of a leucogranitic intrusion of the Mata Azul Suite ....................... 45

Table 2. 11: Representative composition of garnet crystals..................................... 46

Figure 2. 18: Negative correlation of garnet crystals.............................................. 47 
Table 2. 12: Representative composition of beryl crystals .......................................... 48

Figure 2. 19: Current área of the Mata Azul Pegmatitic Field ...................................50

Capítulo 3

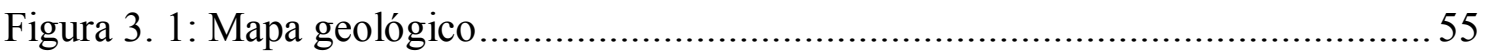

Tabela 3. 1: Composição química de alguns silicatos ..............................................5 57

Figura 3. 2: Classificação do fosfato primário zwieselita ...........................................59

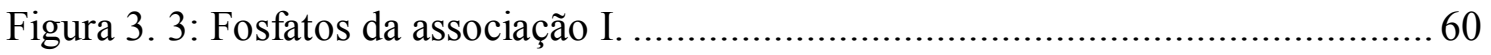

Figura 3. 4: Fotomicrografias e imagens por MEV da associação II. ............................ 62

Tabela 3. 2: Composição representativa de fosfatos das associações I e II. ...................63

Figura 3. 5: Espectro Raman de uma amostra de cavidade ..........................................64

Figura 3. 6: Esquema de alteração para as associações de fosfatos............................... 66 


\section{RESUMO}

No Brazil central, entre os estados de Goiás e Tocantins, vários pegmatitos graníticos foram caracterizados e agrupados pela primeira vez. Estes pegmatitos foram intensamente explorados em busca de gemas no passado, em especial, várias espécies do supergrupo da turmalina e berilo. Pegmatitos simples, portadores de berilo e portadores de turmalina ocorrem em uma área de $200 \mathrm{~km}^{2}$, intrudindo rochas metassedimentares da formação Ticunzal e Grupo Serra da Mesa, rochas graníticas da Suíte Aurumina e leucogranitos da Suíte Mata Azul. Os minerais essenciais destes pegmatitos são: feldspato potássico, que em grande parte está alterado para caulim; quartzo e mica, principalmente muscovita. Os principais minerais acessórios dos pegmatitos portadores de berilo são: berilo, schorlita, granada, albita e agregados de fosfatos de Fe-Mn compostos zwieselita, sarcopsídeo, F-apatita, rockbridgeíta, hagendorfita, heterosita, fosfosiderita e strengita. Estes agregados de fosfatos estão associados com óxidos e hidróxidos de $\mathrm{Fe}$ e $\mathrm{Mn}$, bem como raros cristais de gahnita, uraninita e Fe-columbita. Os principais minerais acessórios nos pegmatitos portadores de turmalina são: turmalina, albita, berilo e trilitionita. $O$ supergrupo da turmalina é representado nestes pegmatitos por cristais pretos de dravita e schorlita, cristais de elbaíta, rossmanita e liddicoatita nas cores verde, azul ou rosa, com algumas amostras mostrando zonas de cores diferentes. Cristais de dravita também são encontrados nas rochas encaixantes, próximo ao contato com o pegmatito. O paragnaisse encaixante de alguns dos pegmatitos simples é afetado pelo metamorfismo de contato e alteração hidrotermal, produzindo primeiramente uma paragênese com diopsídio-hedenbergita, Ca-anfibólio, titanita, allanita e granada, com formação secundária de fluorita e carbonato a partir da allanita e dos inossilicatos. Diques enriquecidos em albitas associados com pegmatitos simples produzem pequenos halos de alteração na rocha encaixante, contendo rutilo, ilmenorutilo e policrásio (Y). Leucogranitos da Suíte Mata Azul são peraluminosos, syn a pós-orogênico com características geoquímicas do grupo pegmatítico-granítico LCT. Análises geocronológicas pelo método U-Pb LA-ICPMS em monazita do pegmatito Boanerges geraram uma idade de $519 \pm 2,8 \mathrm{Ma}$, enquanto a datação química U-Th- $\mathrm{Pb}$ em uraninitas do pegmatito São Júlio revelaram idades entre 500 e $560 \mathrm{Ma}$, que são próximas ou sobrepõe a idade de $560 \mathrm{Ma}$ atribuída aos leucogranitos da Suíte Mata Azul que consta na literatura. Estas idades, as relações de 
campo, a mineralogia e os dados geoquímicos sugerem que a Suíte Mata Azul é a provável fonte para os pegmatitos estudados. A associação mineral dos pegmatitos e a química da granada e berilo foram usados para definir o grau de fracionamento dos pegmatitos e a distância de alojamento dos corpos pegmatitos em relação aos corpos graníticos fonte. É proposto que estes pegmatitos estudados representem um campo pegmatito, nomeado como Campo Pegmatítico da Suíte Mata Azul. É também proposto que as intrusões graníticas da Suíte Mata Azul podem ser usadas como guia prospector para os pegmatitos que produzem gemas, em especial água-marinha e turmalina.

Palavras chave: Pegmatitos graníticos; Suíte Mata Azul; Fosfatos de Fe e Mn 


\section{ABSTRACT}

In central Brazil, specifically in Goiás and Tocantins states, nineteen granitic pegmatites were characterized and grouped for the first time. These pegmatites were intensely explored by hand in the past, producing mainly gemstones varieties of tourmaline and beryl. Simple, beryl- and tourmaline-bearing pegmatites occur in a $200 \mathrm{~km}^{2}$ area where they intrude into regional metassedimentary rocks and leucogranites of the Mata Azul Suite. Potassic feldspar mostly altered to kaolin; quartz and mica, mainly muscovite, are the essential minerals. The main accessory minerals in the berylbearing pegmatites are: beryl, schorl, garnet, albite and Fe-Mn phosphates aggregates which are composed by zwieselite, sarcopside, F-apatite, rockbridgeite, hagendorfite, heterosite, phosphosiderite and strengite. Aggregates of $\mathrm{Fe}$ and $\mathrm{Mn}$ oxides and hydroxides are common and associated with the phosphates concentrations, as well as rare crystals of gahnite, uraninite and Fe-columbite. The major accessory minerals in the tourmaline-bearing pegmatites are: tourmaline, albite, beryl, and trilitionite. The tourmaline supergroup is represented in these pegmatites by black crystals of dravite and schorl, green, blue and pink elbaite, rossmanite and liddicoatite, with many zoned samples. Dravite crystals are also found in the country rocks, near their contact with the pegmatite. The paragneiss around simple pegmatites is affected by thermal metamorphism and hydrothermal alteration, producing an early paragenesis formed by diopside-hedenbergite, Ca-amphiboles, titanite, allanite and garnet, with secondary formation of fluorite and carbonate by the replacement of allanite and the inosilicates. Albite-rich dykes associated with the simple pegmatites produce small alteration halos in the host rock, containing rutile, ilmenorutile and Y-polycrase. Leucogranites of the Mata Azul Suite are peraluminous, syn- to post-orogenic with geochemical characteristics of the LCT granite-pegmatite group. LA-ICPMS U-Pb geocronology in monazite from the Boanerges Pegmatite yielded an age of 519 $\pm 2,8 \mathrm{Ma}$ while U-Th-Pb chemical dating of uraninite from the São Júlio revealed ages between 500 and $560 \mathrm{Ma}$, which are near or overlap the age of $560 \mathrm{Ma}$ attributed to the leucogranites of the Mata Azul Suite in the literature. These ages, the field relationships, the mineralogy and the geochemical data suggest the Mata Azul Suite as the probable source for the studied pegmatites. Mineral association and mineral chemistry of garnet and beryl were used to 
define the degree of fractionation of the pegmatites and their distance of emplacement in relation to the granite source. It is proposed that the group of studied pegmatites perform a pegmatitic field, called Mata Azul Suite Pegmatitic Field. It is also proposed that the Mata Azul granitic intrusions could be used as prospecting guide for the pegmatites that have proven profitable for gemstones exploration, especially aquamarine and tourmaline.

Keywords: Granitic pegmatites; Mata Azul Suite; Fe-Mn phosphates 
INTRODUÇÃO 


\section{CAPÍTULO 1 - INTRODUÇÃO}

\subsection{APRESENTAÇÃO}

A associação que se faz sempre que o termo pegmatito é mencionado diz respeito principalmente ao tamanho gigante que parte de seus cristais pode alcançar. Secundariamente, a mineralogia exótica também é lembrada, pode-se dizer que o pegmatito seja um dos principais alvos na "busca" de fases minerais novas, incomuns ou raras, incluindo-se aí os minerais com qualidade gemológica.

O estudo de pegmatitos, em especial aqueles de composição granítica, bem como de seus plútons parentais, há várias décadas fornece informações de agrupamentos de corpos com importância econômica e/ou científica. Esses agrupamentos que podem se espalhar por dezenas até milhares de quilômetros quadrados são reunidos em campos, distritos e províncias, dos quais o Brasil apresenta vários descritos, a Província Pegmatítica Oriental na região sudeste e a Província Pegmatítica Borborema no nordeste. A região central do Brasil, mais especificamente Goiás e Tocantins possui ocorrências de vários corpos pegmatíticos, no entanto, ainda pouco estudados.

A tese aqui apresentada dedica-se ao estudo de grupos de pegmatíticos graníticos na parte central do Brasil que foram estudados e apresentados sob a forma de dois artigos, um com abrangência maior, tratando do campo pegmatítico e outro caracterizando uma associação mineral composta de fosfatos, muito peculiar a alguns dos pegmatitos estudados.

\subsection{OBJETIVOS}

Os objetivos gerais desta tese foram:

- A caracterização de diferentes pegmatitos graníticos na região de estudo e sua separação por grupos relacionados

- A indicação de provável granito parental com base em dados petrográficos, geoquímicos e isotópicos.

- A proposição de um sistema evolutivo do granito parental ao pegmatito mais evoluído 
- O agrupamento dos corpos cogenéticos em um campo pegmatítico específico.

\subsection{LOCALIZAÇÃO E VIAS DE ACESSO}

A área de estudo (figura 1.1) está situada entre os estados de Góias e Tocantins, abrangendo ao todo quatro municípios, para se chegar a esta região a partir de Brasília, toma-se a BR-080 até o entroncamento com a Belém-Brasília, seguindo-se então para norte até a cidade de Santa Tereza de Goiás, onde se deve seguir pela GO-142 até o município de Montividiu do Norte onde começa a área de estudo, próximo ao distrito de Mata Azul. A continuidade ao norte da GO-142 é a TO-498, já no estado de Tocantins, esta extensão rodoviária é a principal via de acesso no local, a partir dela, inúmeras estradas vicinais e trilhas levam a diferentes ocorrências pegmatíticas.

\subsection{MÉTODOS}

Inicialmente e durante todo o desenvolvimento da tese, extensa bibliografia sobre o tema foi consultada, sobretudo de artigos de revistas científicas especializadas. O desenvolvimento de outros trabalhos precursores na região por pesquisadores e alunos do IG-UnB que também foram de grande valia para o entendimento e consulta de dados da geologia local.

Etapas de campo:

Quatro etapas de campo foram realizadas à região com duração de dois a quatro dias cada uma, com o intuito de encontrar e descrever os corpos pegmatíticos e graníticos dentro das possibilidades apresentadas por cada afloramento, visto que, muitos dos garimpos foram abandonados há muito tempo e tiveram suas áreas de exposição encobertas por vegetação, inundadas ou entupidas com rejeitos. Nas etapas de campo foram coletadas todas as amostras utilizadas no trabalho, cerca de $80 \%$ delas retiradas de pilhas de rejeito nos garimpos, as amostras foram catalogadas e fotografadas em sua maior parte. 


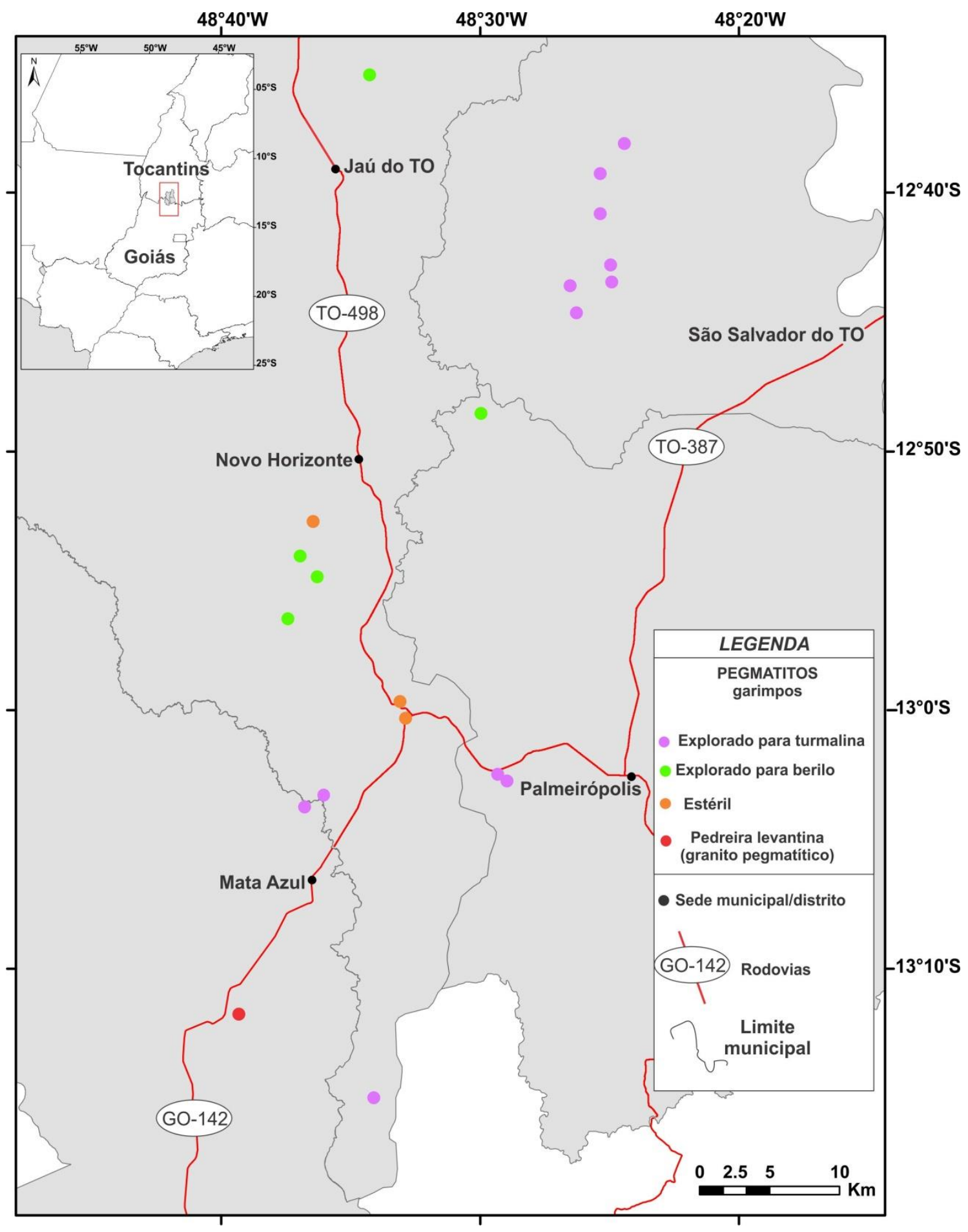

Figura 1. 1: Mapa de localização mostrando várias ocorrências pegmatíticas

Produção de lâminas e seções polidas:

Cerca de 90 lâminas e 20 seções polidas foram confeccionadas no Laboratório de Laminação do Instituto de Geociências da UnB. As lâminas e seções foram utilizadas em variados métodos para identificação, classificação e/ou descrição da amostra nas quais estas representam. 
Microscopia e análise em lupas:

A descrição microscópica de rochas graníticas, encaixantes, associações de fosfatos e alguns outros minerais de pegmatitos foram feitas em microscópio petrográfico modelo Olympus BX60. Foi utilizada ainda uma lupa binocular Zeiss, modelo Discovery V20 para observação de minerais e fotografia, no IG-UnB.

\section{Microssonda Eletrônica:}

Análises químicas pontuais em turmalinas, micas, granadas, fosfatos e outros minerais foram realizados em uma sonda eletrônica $J E O L$, modelo superprobe $J X A$ 8230 , utilizando voltagem de $15 \mathrm{Kv}$ e corrente de $10 \mu \mathrm{A}$, os padrões de elementos empregados para fosfatos foram: albita $(\mathrm{Na})$, microclínio $(\mathrm{K}, \mathrm{Al}), \mathrm{ZnO}$ vidro $(\mathrm{Zn})$, forsterita $(\mathrm{Mg})$, andradita $(\mathrm{Si}, \mathrm{Ca}, \mathrm{Fe})$, topázio $(\mathrm{F})$, pirofanita $(\mathrm{Mn})$ e apatita $(\mathrm{P})$. Para os demais minerais utilizou-se: Albita $(\mathrm{Na})$, Microclínio (K), Wollastonita ( $\mathrm{Si}$ e $\mathrm{Ca}$ ), Topázio (F), Vanadinita (V e Cl), $\mathrm{TiMnO}_{3}$ ( $\mathrm{Ti}$ e Mn), $\mathrm{Fe}_{2} \mathrm{O}_{3}$ (Fe), Olivina (Mg), Barita $(\mathrm{Ba})$, Selestita (Sr), Pollucita (Cs), Tantalita (Ta), Columbita ( $\mathrm{Nb})$, Vidros artificiais com 3,5\% de óxidos variados (ETR), Uraninita (U) e Galena (Pb). As análises foram realizadas no Laboratório de Microssonda Eletrônica no IG-UnB.

\section{Microscopia eletrônica de varredura (MEV):}

Imagens de micro-cristais de fosfatos foram feitas no Laboratório de Microscopia Eletrônica de Varredura do IG-UnB, em um aparelho FEI Quanta 450 - EDS EDAX.

Análise química de rochas:

Inicialmente as amostras separadas para esta etapa foram previamente fragmentadas, britadas e pulverizadas no laboratório de preparação de amostras do IGUnB, na pulverização foi utilizado um moinho de panela com revestimento de ágata para evitar contaminação de determinados metais. Os resultados químicos de amostras de granito pegmatítico, rocha encaixante e alguns blocos de zonas diferenciadas de pegmatitos foram obtidos através dos laboratórios Acme Analytical ltd., utilizando ICPAES e ICP-MS para quantificação dos elementos, os óxidos maiores e traços foram preparados por meio da fusão de $0.2 \mathrm{~g}$ de amostra com tetraborato de lítio e digestão nítrica diluída. Metais base e metais preciosos foram analisados em $0,5 \mathrm{~g}$ de amostra digerida em água-régia quente à $95^{\circ} \mathrm{C}$. 


\section{Difração de raios X:}

A identificação de fases por meio da difração de raios $\mathrm{X}$ foi realizada em laboratório do IG-UnB, em um difratômetro Rigaku modelo Ultima IV, com tubo de cobre, filtro de níquel de $35 \mathrm{kV}$ e $15 \mathrm{~mA}$, a varredura das amostras foi feita em $5^{\circ}$ por minuto no intervalo $2 \theta$ de 3 a $80^{\circ}$.

\section{Espectroscopia Raman:}

A utilização de micro Raman teve como intuito, o auxílio na identificação de fases minerais presentes nas massas de fosfatos e como inclusões em cristais de muscovita, no primeiro caso, foi utilizado um aparelho Jobin Yvonspex Hoiba modelo T64000, com objetiva de 50x, detector CCD refrigerado a nitrogênio líquido, o espectro Raman foi excitado por um feixe de argônio de comprimento de onda de $514.5 \mathrm{~nm}$ e tempo de aquisição de 10 segundos com integração de $3 \mathrm{x}$, este equipamento está instalado no Instituto de Física da UnB. Nas inclusões em muscovita foi utilizado aparelho Renishaw $R L 633$, com laser de comprimento de onda de $632,8 \mathrm{~nm}$, referência de silício e, objetivas de 5 e 50x de aumento, este aparelho está localizado no Instituto de Química da UnB. Para as medidas por Raman foram utilizadas lâminas polidas de fosfatos e finas "placas" de mica. O banco de dados utilizado para comparação de espectros está hospedado no site rruff.info.

\section{Datações}

Para a obtenção das idades de dois pegmatitos foram utilizados dois métodos diferentes. No primeiro foram datados (U-Pb) cristais de monazita por LA-MC-ICP-MS em padrão de monazita (44069) com spot de $25 \mu \mathrm{m}$ e freqüência de $10 \mathrm{~Hz}$. O segundo método geocronológico utilizado foi a datação química de uraninita em microssonda eletrônica, com os resultados de $\mathrm{U}$ e $\mathrm{Pb}$ em \% peso aplicados na equação simplificada (3) de Bowles (1990), onde, $t=\lambda_{1}{ }^{-1} \ln \left(\frac{1.104 P b}{U+1}\right)$. Tentativas de datação por U-Pb em zircão foram realizadas em vários corpos pegmatíticos e em granito evoluído, no entanto, a escassez de cristais e a qualidade dos zircões, muito metamíticos, em valores altos de $\mathrm{Pb}$ comum não possibilitaram a obtenção de idades razoáveis. $\mathrm{O}$ método isotópico foi realizado no laboratório de geocronologia da Universidade de Brasília. 


\subsection{CONTEXTO GEOLÓGICO}

A área de estudo está inserida na Província Estrutural do Tocantins, que pode ser entendida como um sistema orogênico formado por extensas faixas de dobramentos (Araguaia, Paraguai e Brasília) suturando áreas cratônicas, representadas pelos crátons Amazônico, do São Francisco e Paranapanema, este último encoberto pelas rochas da Bacia do Paraná (figura 2.1).

Toda a evolução geológica desta região se deve a processos de ruptura e aglutinação continental iniciados ainda no ciclo transamazônico, quando o supercontinente Atlântica foi formado (Dardenne 2000). Os resquícios deste antigo continente podem ser considerados as unidades mais antigas que formam os Blocos Cavalcante-Natividade e o Maciço de Goiás que abrange diversos ambientes geológicos/tecnônicos (Pimentel et al. 2000, Fuck et al. 2014) com idades de eventos paleoproterozóicos até o neoproterozóico no ciclo Brasiliano.

Na região de estudo, centro da Província Tocantins, a Formação Ticunzal e Suíte Aurumina compõem um embasamento intensamente deformado num domínio rúptildúctil (Alvarenga et al. 2007). A Formação Ticunzal é formada por rochas metassedimentares que englobam xistos variados e paragnaisses, localmente grafitosos, metaconglomerados e quartzitos, afetados por condições metamórficas de fácies anfibolito média (Fuck et al. 1988, Alvarenga et al. 2007). A Suíte Aurumina é intrusiva na Formação Ticunzal e é constituída por granitóides peraluminosos, na maior parte sin-tectônicos, contendo nódulos ou aglomerados de grafita (Botelho et al. 1999), cujas idades variam entre 2,0 e 2,2Ga (Sparrenberger \& Tassinari 1999, Alvarenga et al. 2007;).

Este embasamento experimentou ao redor de 1,8 Ga. um processo de rifteamento, evidenciado por volta de $1.77 \mathrm{Ga}$ por intenso vulcanismo bimodal intraplaca e pela colocação dos primeiros granitos do tipo A da Província Estanífera de Goiás (Pimentel et al. 1991). Estes granitos férteis apresentam importante mineralização de estanho e índio, associada a processos de albitização e greisenização, além de intrusões pegmatíticas (Botelho 1992; Botelho \& Moura 1998). Araújo Filho et al. (2007) correlacionam certos gnaisses e granito foliado da Suíte Rio das Almas a Suíte Serra Dourada, que faz parte da Província Estanífera. 
O preenchimento do rift por rochas do Grupo Araí avança com a ocorrência de uma transgressão marinha que extrapola a sedimentação dentro dos limites do rift. As litologias sílico-carbonáticas relacionadas ao estágio pós-rift do Grupo Araí fazem parte do Grupo Serra da Mesa, e têm a época de deposição estimada entre 1.57 e 1.47 Ga (Dardenne 2000; Marques 2009), posteriormente esses metassedimentos foram bastante afetados pela Orogenia Brasiliana, que formou o domínio conhecido como Faixa Brasília. Também, nesta época, em torno de 1,6 Ga, ocorre a formação dos granitos mais jovens da Província Estanífera, como Serra Dourada e Serra da Mesa.

Rossi et al.(1996) e Kitajima (2001) datam em 1.5 Ga até $1.47 \mathrm{Ga}$ o corpo alcalino da Suíte do Peixe que é intrusiva nas rochas metassedimentares do Grupo Serra da Mesa. O complexo é constituído predominantemente por metasienitos afetados tardiamente pela Orogenia Brasiliana de forma moderada. Importantes concentrações de zircão, allanita, monazita e coríndon ocorrem neste corpo, em parte associadas à fácies pegmatíticas (Kitajima 2001).

Ao redor de $950 \mathrm{Ma}$ existia uma crosta oceânica oriunda da fragmentação do Rodínia que após certa desestabilização formou sucessivos arcos de ilhas acrescionários entre os Crátons Amazônico e do São Francisco, denominado de Arco Magmático de Goiás (Pimentel et al. 2005). Sequências Metavulcanossedimentares, ortognaisses e granitóides compõem as rochas destes arcos que foram sendo acrescionados aos terrenos mais antigos do embasamento da Província Tocantins Central e dos crátons sucessivamente durante eventos colisionais do Brasiliano até cerca de $600 \mathrm{Ma}$ (Dardenne 2000), além de alguns corpos ígneos pós evento colisional. Entre os corpos tardios e posteriores a orogenia, destaca-se a Suíte Mata Azul, constituída por rochas graníticas evoluídas e pegmatitos com idade de 560Ma (Polo \& Diener 2013).

Em outras áreas do Tocantins, ocorrem pegmatitos de afiliação saturada e insaturada em sílica, na região central, nas proximidades dos municípios de Monte Santo e Paraíso do Tocantins; Lamarão \& Kotschoubey (1996) descrevem veios pegmatíticos contendo berilo dentro de granitos peraluminosos do tipo "S" da Suíte Santa Luzia, já Iwanuch (1991) e Viana et al. (2009) mostram a ocorrência de grandes bolsões pegmatíticos constituídos basicamente por feldspatos, nefelina, cancrinita, sodalita e biotita em rochas sieníticas do Complexo Alcalino Monte Santo. 


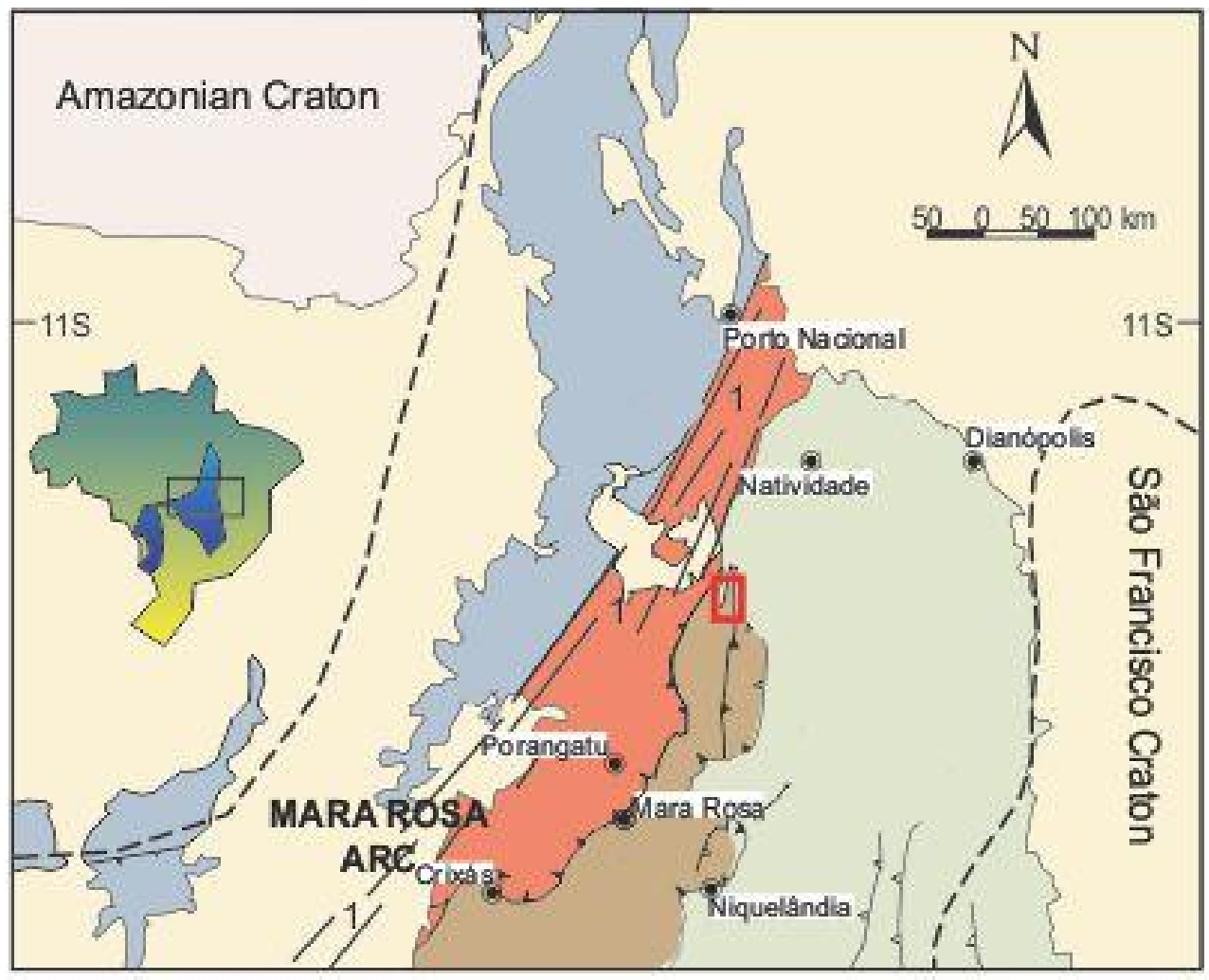

LEGEND

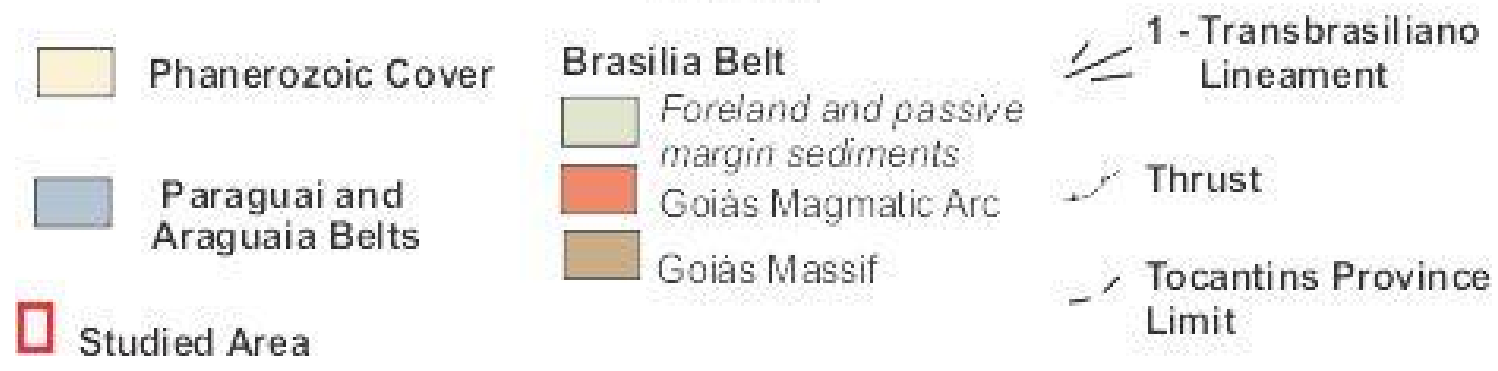

Figura 1. 2 :Mapa simplificado da Província Estrutural Tocantins. 
Capítulo enviado como artigo para a Journal of South American Earth Science

THE MATA AZUL PEGMATITIC FIELD, TOCANTINS/GOIÁS, CENTRAL BRAZIL: GEOLOGY, GENESIS AND MINERALIZATION. 


\section{CAPÍTULO 2}

The Mata Azul Pegmatitic Field, Tocantins/Goiás, central Brazil: geology, Genesis and mineralization.

\subsection{ABSTRACT}

In central Brazil, specifically in Goiás and Tocantins states, several granitic pegmatites were characterized and grouped for the first time. These pegmatites were intensely explored by hand in the past, producing mainly gemstone varieties of tourmaline and beryl. Simple, beryl- and tourmaline-bearing pegmatites occur across a $200-\mathrm{km}^{2}$ area where they intrude into regional metassedimentary rocks and into peraluminous granites. K-feldspar (mostly altered to kaolin), quartz and mica (mainly muscovite) are the major minerals. The main accessory minerals in the beryl-bearing pegmatites are beryl, schorl, garnet, albite and Fe-Mn phosphate aggregates. The main accessory minerals in the tourmaline-bearing pegmatites are tourmaline, albite, beryl, and trilithionite. The paragneiss surrounding the simple pegmatites was affected by thermal metamorphism and later hydrothermal alteration, producing $\mathrm{Ca}$-silicates, $\mathrm{Ti}-\mathrm{Nb}$ Y oxides and sulfides. Leucogranites of the Mata Azul Suite are peraluminous and synto post-orogenic with geochemical characteristics of the LCT granite-pegmatite group. LA-ICP-MS U-Pb geochronology in monazite yielded an age of $519 \pm 2.8$ Ma. Additionally, U-Th-Pb chemical dating of uraninite revealed a maximum age between 500 and $560 \mathrm{Ma}$, which is similar to the age of $560 \mathrm{Ma}$ attributed to the leucogranites of the Mata Azul Suite in the literature. These ages, the field relationships, the mineralogy and the geochemical data suggest that the Mata Azul Suite is the probable source of the studied pegmatites. The mineral associations and mineral chemistry were used to define the degree of fractionation of the pegmatites and their distance of emplacement in relation to the granite source. It is proposed that the group of studied pegmatites represent a pegmatitic field, called the Mata Azul Suite Pegmatitic Field. 


\subsection{INTRODUCTION}

Pegmatite is a singular group of igneous rocks that usually exhibits exotic mineralogy and geochemistry. One of their main characteristics is that their genesis can be either from an evolved magma or from the anatexis of a protolith. Among the great number of pegmatite compositions, those with a granitic origin are the most studied, either because of their more common genesis or because of their economic potential. It even became common to associate the word "pegmatite" with the ones with a granitic composition. Although this type of rock has small dimensions compared to other types, pegmatites are considered to be economically important because of their industrial minerals, rare metals and especially for their gems. In the north of Goiás and in the south of Tocantins, pegmatites were found and mined by hand for decades but have never been properly studied. This study, for the first time, characterizes groups of pegmatites, assembling them into a pegmatitic field, and proposes a source for the pegmatite magma. The delimitation of a pegmatitic field with a probable parental rock can help to identify new occurrences of mineral resources from granitic pegmatites. The study of this pegmatitic field and known occurrences of pegmatites associated with other older suites in Tocantins and Goiás states could result in new districts and a pegmatitic province in central Brazil.

\subsection{GEOLOGICAL SETTING}

The studied area lies in the Tocantins Structural Province, classified as a Neoproterozoic orogenic system composed of extensive fold belts (Araguaia, Paraguai and Brasília) connecting three continental blocks: the Amazon craton, the São Francisco craton and the Paranapanema block (Almeida et al., 1981) (figure 2.1). The Mata Azul granites and pegmatites crop out in the Brasília Fold Belt, a large Brasiliano/PanAfrican orogenic belt in central Brazil. The geological framework of the Brasília Belt basement, known as the Goiás Massif in figure 1, is represented by i) Archean granitegreenstone terranes; ii) Paleoproterozoic metasedimentary, metavolcanic and metaplutonic rocks related to the Campinorte Magmatic Arc; iii) Mesoproterozoic rift to post-rift sequences constituted by A-type tin-bearing granites of the Goiás Tin Province and metasedimentary rocks of the Serra da Mesa Group; and iv) Meso- to 
Neoproterozoic metavolcano-sedimentary sequences and layered mafic-ultramafic complexes. In a recent mapping program, Araújo et al. (2016) added granitic rocks of the Aurumina Suite and metasedimentary rocks of the Ticunzal Formation to the geological context of the studied region (figure 2.2). Until now, these Paleoproterozoic units were only described in the external zone of the Brasília Fold Belt (Botelho et al. 2006). An important component of the Brasília Belt is the Goiás Magmatic Arc, a Neoproterozoic juvenile volcanic/plutonic association, extending N-S for approximately 800 km (Pimentel and Fuck, 1992, Pimentel et al., 2011; Cordeiro et al., 2014). The Goiás Magmatic Arc is divided into the Arenópolis arc to the south, and the Mara Rosa arc to the north. The latter is composed of metavolcano-sedimentary sequences, tonalitic-granodioritic orthogneisses, and post-orogenic intrusions represented by gabbro-diorite and granite plutons. The Mata Azul granites and pegmatites are related to the evolution of the Mara Rosa Arc and are represented by a small number of $560 \mathrm{Ma}$ post-collisional intrusions Polo \& Diener (2013).

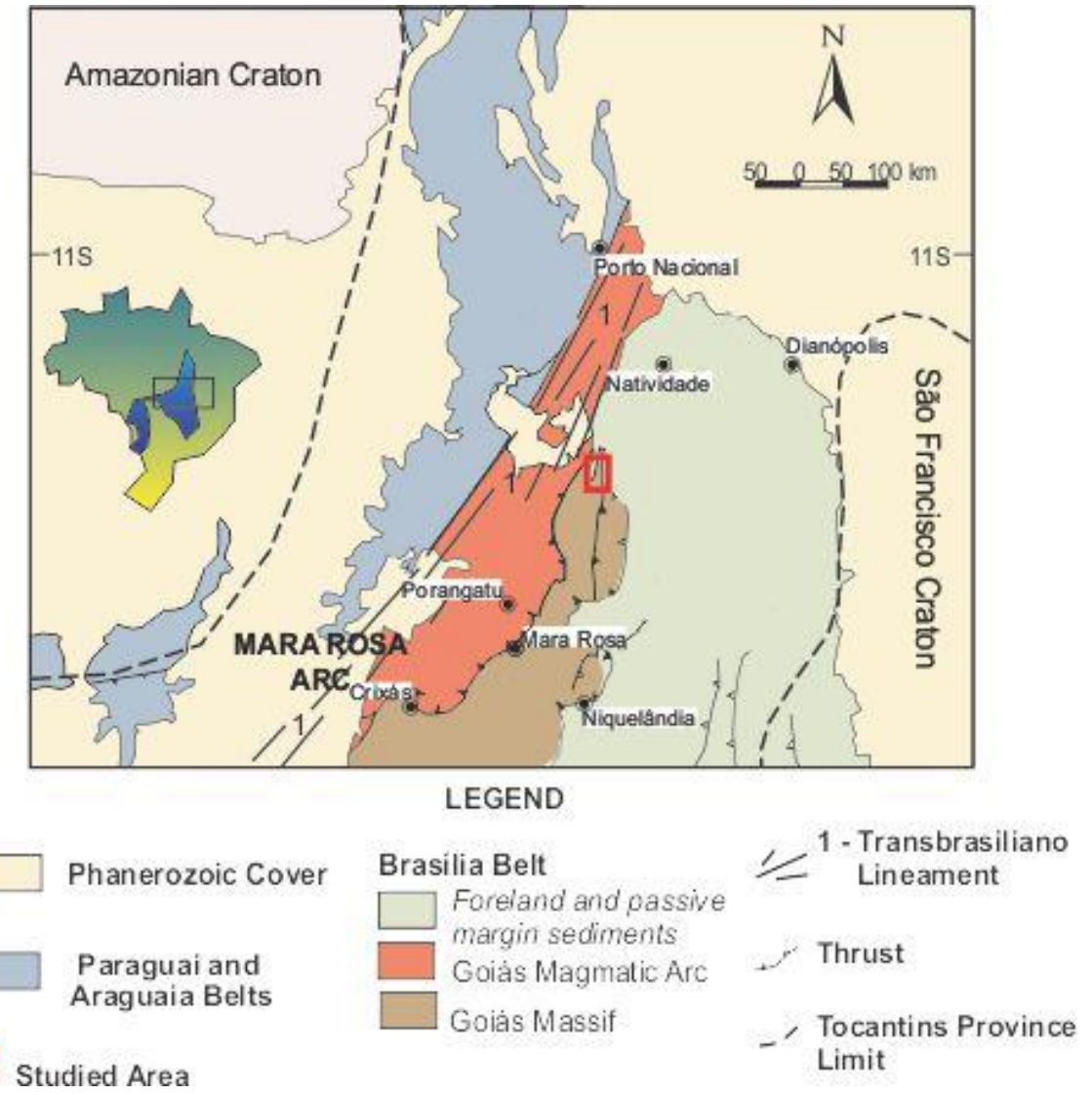

Figure 2. 1: Simplified map of the Tocantins Structural Province with the studied área in red. Fuck et al. 2014. 


\subsection{MATERIALS AND METHODS}

Field and Sampling:

At this stage, all of the samples analyzed in this study were collected, $80 \%$ of them from mining tailings, rests of ancient artisanal mining. Since many of the mining sites were abandoned, vegetation, water and tailings had been taking over their area. The samples were catalogued and photographed.

\section{Method of Analysis:}

Identification and chemical analysis of the minerals in pegmatites were performed following different techniques. X-ray diffraction, by powder method, was obtained in a of Rigaku ULTIMA IV unit, operated with a copper tube in $35 \mathrm{kV}$ and $15 \mathrm{~mA}$ with a scan rate of five degrees per minute in the range of $2 \theta$ of three to eighty degrees. Mineral compositions were determined in a electron probe microanalyser (EPMA) JEOL JXA-8230 superprobe with five spectrometers using a voltage of $15 \mathrm{kV}$ and a current of 10nA. The patterns used were: albite $(\mathrm{Na})$, microcline $(\mathrm{K})$, Wollastonite ( $\mathrm{Si}$ and $\mathrm{Ca}$ ), Topaz (F), vanadinite (V, and $\mathrm{Cl}$ ), $\mathrm{TiMnO}_{3}$ ( Ti and $\left.\mathrm{Mn}\right), \mathrm{Fe}_{2} \mathrm{O}_{3}(\mathrm{Fe})$, forsterite $(\mathrm{Mg})$, barite $(\mathrm{Ba})$, Celestite $(\mathrm{Sr})$, pollucite $(\mathrm{Cs})$, tantalite, Columbite $(\mathrm{Ta})(\mathrm{Nb})$, artificial glass with 3.5 percent of various oxides (ETR), uraninite $(\mathrm{U})$ and galena $(\mathrm{Pb})$. The identification of certain oxides included in muscovite lamellae was made with the aid of Raman Spectroscopy with the Renishaw RL633 machine using a laser with a wavelength of $632,8 \mathrm{~nm}$, silicon reference and an objective lens of five and fifty times magnification. SEM and EDS analyses were also performed to identify mineral inclusions. Whole rock geochemical analyses were obtained in the Acme Analytical Laboratories, using ICP-AES for major elements and ICP-MS for trace elements. Major, rare earth and refractory elements were determined following a lithium tetraborate fusion and nitric acid digestion of a $0.2 \mathrm{~g}$ sample. A separate $0,5 \mathrm{~g}$ split was digested in aqua regia for base and precious metals analysis.

Two different methods were used for dating the pegmatites. The first monazite crystals were dated by LA-MC-ICP-MS in a monazite standard (44069) with a spot of $25 \mu \mathrm{m}$ and a frequency of $10 \mathrm{~Hz}$. The second geochronological method used was 
chemical dating of uraninite in the electron microprobe, with the results of $\mathrm{U}$ and $\mathrm{Pb}$ in percentage weight applied in equation (3) of Bowles (1990).

\subsection{THE GRANITIC PEGMATITES}

The acknowledgement of the pegmatite intrusions in Goiás and Tocantins states, from both miners and literature, dates back many years. Macambira (1983), Marini \& Botelho (1986), Botelho \& Moura (1998), Sparrenberger \& Tassinari (1999), Pereira (2002), and Araújo Filho et al. (2016) mention pegmatite intrusions associated with the Goiás Tin Province and granitic rocks of the Aurumina Suite. In the south of Tocantins state, the municipalities of Palmeirópolis, São Salvador and Jaú do Tocantins hold the majority of pegmatite and granite pegmatite intrusions. Some of those intrusions have never been described in the specialized literature; among them, at least ten are mineralized and had been mined (Queiroz, 2010).

Marimbondo, also known as Marimbondão, was the first pegmatite body found in the region in the 1970s, leading to the discovery of numerous other pegmatite intrusions, as reported by local artisanal miners. The 1970s and 1980s were the peak time of beryl (gem and industrial) and tourmaline mining in the area. During the 1990s, the mineral extraction declined, leading to mine abandonment and consequently to an obstruction of access. Some of the mining workers returned sporadically to old and easily accessed mining sites in order to extract aquamarine to sell. Because of the abandonment, the mining sites became covered by water, vegetation and tailings, leading to great difficulty in describing the details of the pegmatite bodies.

During the development of this study, twenty-five occurrences of pegmatites and granites were visited (figure 2.2). Most of them were located in the state of Tocantins (near the cities of Palmeirópolis, São Salvador and Jaú do Tocantins). Some of the occurrences were located in Goiás state, more specifically in the region of Montividiu do Norte. This study has focused on pegmatite intrusions with beryl and tourmaline mineralization and on smaller non-mineralized pegmatite bodies.

The mineralized pegmatites can be divided into two main groups, pegmatites explored for beryl and pegmatites explored for tourmaline. Based on current 
descriptions, the pegmatite bodies were named in this study as follows: Onça, Pichorra, São Júlio, Fazenda Mesquita, Jóia da Mata, outcrops "4", "5" and "6", Córrego das Pedras, Marimbondo, Marimbondinho, Zé do Fole, Boanerges, Índio, Marta Rocha and Berilão. Despite the abundance of barren pegmatite dykes in the studied area, most of them are strongly altered; only three fresh barren granite-pegmatite and pegmatite outcrops were well described: Levantina quarry and outcrops "16" and "17" (figure 2.2). 


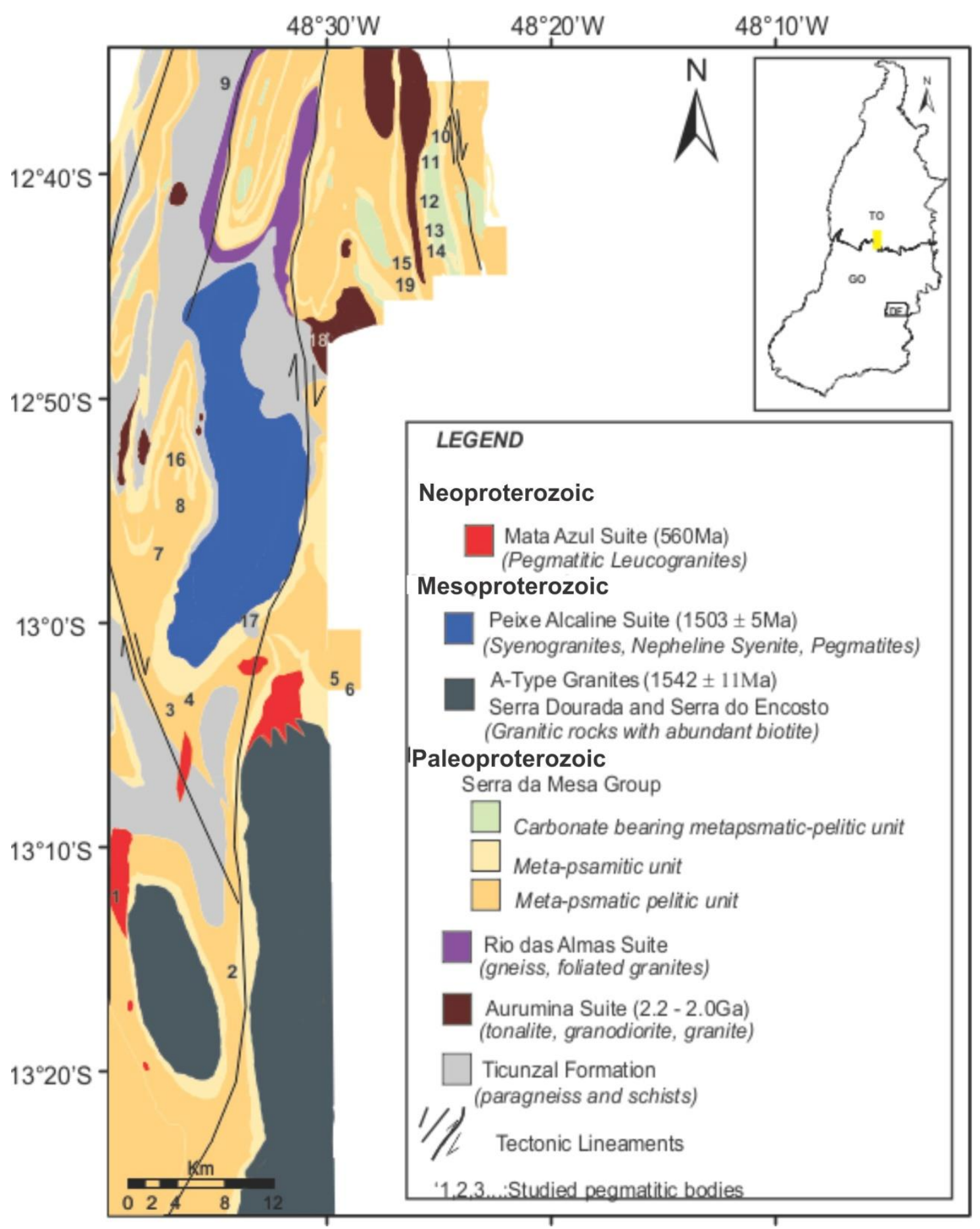

Figure 2. 2: Geological map with the studied points represented by the numbers. 1: Levantina quarry, 2: Córrego das Pedras, 3: Jóia da Mata, 4: “4”, 5: "5”, 6: “6”, 7: São Júlio, 8: Pichorra, 9: Fazenda Mesquita, 10: Berilão, 11: Marta Rocha, 12: Zé do Fole, 13: Índio, 14: Boanerges, 15: Marimbondo, 16: “16”, 17: “17”, 18: Onça, 19: Marimbondinho. Map based in Polo \& Diener (2013) and Araújo Filho et al. (2017). 


\subsubsection{Pegmatites explored for beryl}

There are four beryl-bearing pegmatites: Onça, Pichorra, São Júlio and Fazenda Mesquita (figures 2.2 and 2.3). All of them have limited accessible areas, due to either submergence or blocking of the access tunnels. Nevertheless, the observations and mineralogical characterizations (table 2.1) indicate a possible textural and mineralogical zoning in the pegmatites explored for beryl.

Quartz and kaolin from potassic feldspar alteration are the main materials found in tailing samples and they form a decompose wall zone. The K-feldspar crystals have a centimetric scale and show high-grade hydrolysis alteration. Large blocks of quartz with muscovite aggregates can also be found. They often contain green, centimetric beryl crystals, and rare biotite. The muscovite has a silver color, usually with iron oxide inclusions, and it can form millimeter-scale yellow aggregates when in association with blocks of large quartz or K-feldspar crystals. Many schorl crystal fragments were found in the Onça and São Júlio pegmatites. Albite crystals are more common in the Onça pegmatite, where plagioclase crystal sizes are up to ten centimeters and host smaller millimeter-scale crystals of almandine (figure 2.3) and schorl. Although there is a lack of beryl crystals in the tailing samples, two transparent crystal fragments from São Júlio pegmatite were found, one light blue (figure 2.3) and another light green, that could represent the chemical composition of aquamarine crystals previously mined from this igneous body. Fragments of bright yellow beryl are the heliodore variety. Table 2 shows the chemical compositions of the main minerals found in beryl-bearing pegmatite bodies.

In addition to this basic mineral assemblage from a typical beryl-bearing pegmatite, some nodules and aggregates of $\mathrm{Fe}$ and $\mathrm{Mn}$ phosphates (figure 3 ) are found with exotic disposition. These include triplite - $\left(\mathrm{Mn}^{2+}, \mathrm{Fe}^{2+}, \mathrm{Mg}, \mathrm{Ca}\right)_{2}\left(\mathrm{PO}_{4}\right)(\mathrm{F}, \mathrm{OH})$; heterosite $-\left(\mathrm{Fe}^{3+}, \mathrm{Mn}^{3+}\right) \mathrm{PO}_{4}$, frondelite $-\left(\mathrm{Mn}^{2+}, \mathrm{Fe}^{2+}\right) \mathrm{Fe}^{3+}{ }_{4}\left(\mathrm{PO}_{4}\right)_{3}(\mathrm{OH})_{5}$; rockbridgeite - $\left(\mathrm{Fe}^{2+}, \mathrm{Mn}^{2+}\right) \mathrm{Fe}^{3+}{ }_{4}\left(\mathrm{PO}_{4}\right)_{3}(\mathrm{OH})_{5} ;$ phosphosiderite - $\mathrm{Fe}^{3+} \mathrm{PO}_{4} 2 \mathrm{H}_{2} \mathrm{O} ;$ sarcopside $\left(\mathrm{Fe}^{2+}, \mathrm{Mn}^{2+}, \mathrm{Mg}\right)_{3}\left(\mathrm{PO}_{4}\right)_{2}$; strengite $-\mathrm{Fe}^{3+} \mathrm{PO}_{4} 2 \mathrm{H}_{2} \mathrm{O}$; and common phosphates, such as apatite. The complete characterization of these phosphates can be found in Queiroz et al. (in preparation). In association with the phosphates, there were also traces of Fe and Mn oxides and hydroxides, phosphate alteration products, spessartine garnet, Fecolumbite, gahnite and uraninite. 
Table 2. 1: List of minerals identified in beryl-bearing pegmatites

\begin{tabular}{cccc}
\hline & \multicolumn{2}{c}{ Beryl-bearing pegmatites } & \\
\cline { 2 - 3 } Quartz & microcline & Albite & Kaolin \\
Biotite & Muscovite & Schorl & Almandine \\
Spessartine & Green beryl & Aquamarine & Heliodor \\
Fe oxides & Mn oxide & Gahnite & Uraninite \\
Fe-columbite & Triplite & Ferrisicklerite & Heterosite \\
Frondelite & Sarcopside & Rockbridgeite & Fosfosiderite \\
Strengite & Apatite & & \\
\hline
\end{tabular}

Table 2. 2: Chemistry composition of minerals found in beryl-bearing pegmatites

\begin{tabular}{|c|c|c|c|c|c|}
\hline & Light blue beryl & Light Green beryl & Muscovite & Almandine & Schorl \\
\hline $\mathrm{SiO}_{2}$ & 65.45 & 65.44 & 45.54 & 35.19 & 34.69 \\
\hline $\mathrm{TiO}_{2}$ & & & & 0.12 & 0.37 \\
\hline $\mathrm{B}_{2} \mathrm{O}_{3}$ & & & & & 10.25 \\
\hline $\mathrm{Al}_{2} \mathrm{O}_{3}$ & 18.5 & 18.38 & 34.57 & 22.55 & 30.84 \\
\hline $\mathrm{FeO}$ & 0.73 & 0.68 & 3.85 & 29.16 & 16.45 \\
\hline $\mathrm{MgO}$ & & & 0.27 & 0.72 & 2.30 \\
\hline $\mathrm{MnO}$ & 0.03 & & 0.09 & 12.04 & 0.14 \\
\hline $\mathrm{CaO}$ & & & & 0.28 & 0.01 \\
\hline $\mathrm{Li}_{2} \mathrm{O}^{*}$ & & & 0.40 & & \\
\hline $\mathrm{Na}_{2} \mathrm{O}$ & 0.30 & 0.38 & 0.56 & & 2.74 \\
\hline $\mathrm{K}_{2} \mathrm{O}$ & 0.03 & 0.03 & 10.24 & & 0.02 \\
\hline $\mathrm{Rb}_{2} \mathrm{O}$ & 0.05 & 0.04 & & & \\
\hline $\mathrm{Cs}_{2} \mathrm{O}$ & 0.05 & 0.11 & & & \\
\hline $\mathrm{F}$ & & & 1.52 & & 0.71 \\
\hline $\mathrm{H}_{2} \mathrm{O}^{*}$ & & & 3.74 & & 3.20 \\
\hline $\mathrm{O}=\mathrm{F}$ & & & 0.64 & & \\
\hline \multirow[t]{2}{*}{ Total } & 99.93 & 99.89 & 100.1 & 100.05 & 101.72 \\
\hline & & \multicolumn{2}{|c|}{ Formula contents } & & \\
\hline $\mathrm{Si}$ & 5.965 & 5.972 & 6.117 & 2.868 & 5.88 \\
\hline $\mathrm{Ti}$ & & & & 0.007 & 0.047 \\
\hline B & & & & & $3^{\#}$ \\
\hline $\mathrm{Al}$ & 1.987 & 1.977 & 5.475 & 2.179 & 6.165 \\
\hline $\mathrm{Fe}$ & 0.056 & 0.052 & 0.432 & 2.058 & 2.33 \\
\hline $\mathrm{Mg}$ & & & 0.053 & 0.087 & 0.58 \\
\hline $\mathrm{Mn}$ & 0.002 & & 0.010 & 0.831 & 0.02 \\
\hline $\mathrm{Ca}$ & & & & 0.024 & 0.002 \\
\hline $\mathrm{Li}$ & & & 0.214 & & 0 \\
\hline $\mathrm{Na}$ & 0.053 & 0.067 & 0.147 & & 0.901 \\
\hline $\mathrm{K}$ & 0.001 & 0.001 & 1.755 & & 0.004 \\
\hline $\mathrm{Rb}$ & 0.001 & 0.001 & & & \\
\hline Cs & & 0.001 & & & \\
\hline $\mathrm{F}$ & & & 0.645 & & 0.381 \\
\hline $\mathrm{OH}$ & & & 3.355 & & 3.619 \\
\hline
\end{tabular}



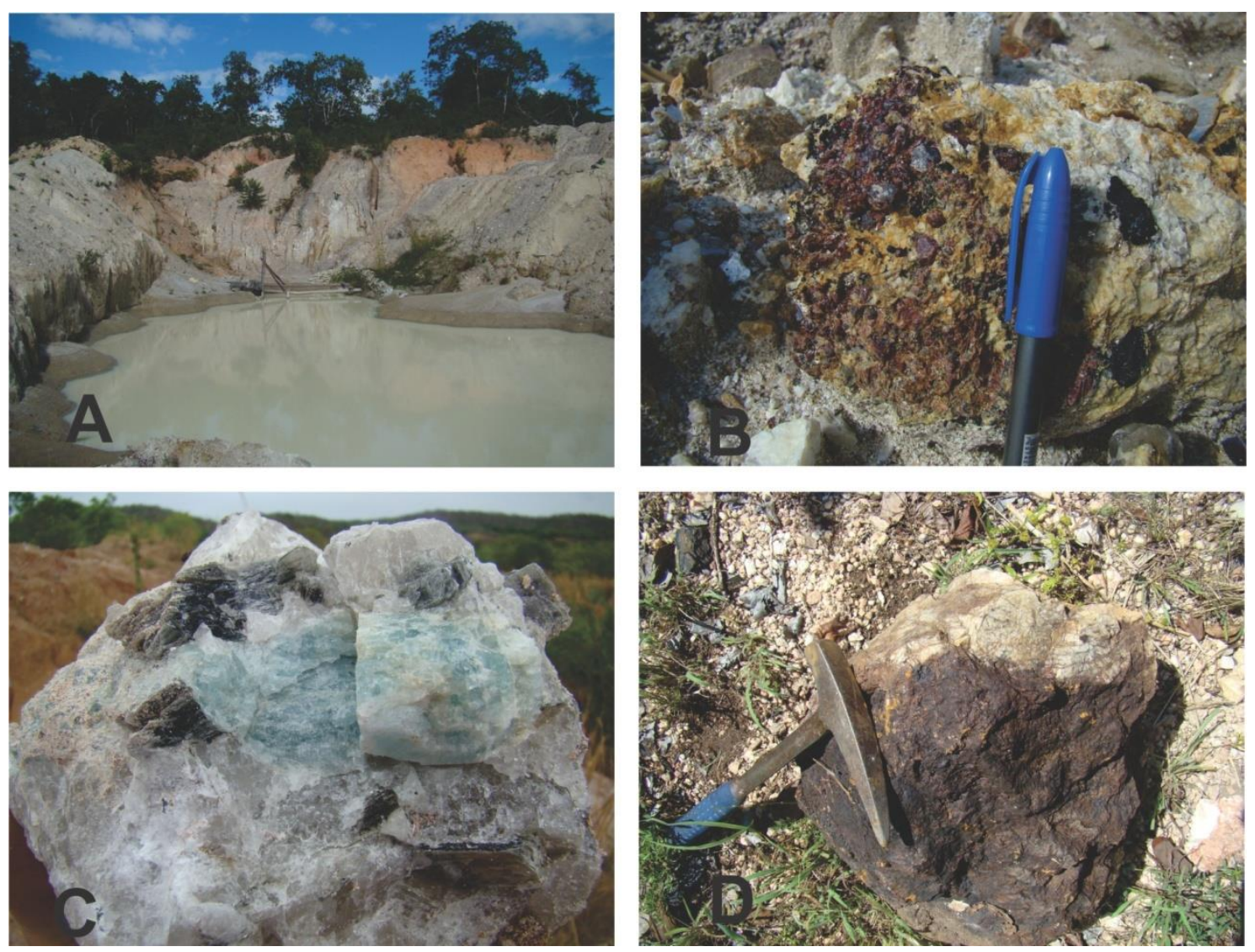

Figure 2.3: Pegmatites explored for beryl (A): Submerged area in the Onça pegmatite. (B): Red almandine crystals from the Onça pegmatite. (C): Sample with blue beryl crystal found in the São Júlio pegmatite. (D): Aggregate of FeMn phosphates from the Fazenda Mesquita pegmatite.

\subsubsection{Pegmatites explored for tourmaline}

The pegmatites explored for tourmaline in Goiás and Tocantins occur in different landscapes, such as in flat to considerably wavy terrain, on the tops and slopes of hills, and on the slopes of the Serra Dourada mountain range. The pegmatite bodies have round to elongated shapes in NE-SW, with dimensions ranging from tens to hundreds of meters, as exemplified by the 200-m-long Marimbondo pegmatite. The tourmalinebearing pegmatites can be separated into two different groups: the southern group, which is composed of the Jóia da Mata, Córrego das Pedras, "4", "5" and "6" pegmatite bodies, and the Northern group, which contains the Marimbondo (figure 2.4), Marimbondinho, Zé do Fole, Índio, Boanerges, Marta Rocha and the Berilão (figure 2.2) pegmatite bodies. Only a altered wall zone is observed in situ in all this pegmatites.

Both groups show a similar mineralogy in both essential and accessory minerals. Kaolin from potassic feldspar alteration is the main component for these rocks in the wall zone, which accounts for almost all of their exposed area. Only a small number of 
pegmatite bodies, such as Maribondo, feature exposures of a considerably fresh part of the intrusion. Quartz crystals are commonly surrounded by kaolin, and intergrowth with potassic feldspar which usually indicates a graphic texture. Preserved K-feldspar crystals were identified as microcline under the microscope due to their characteristic cross-hatched twinning and albite exsolution.
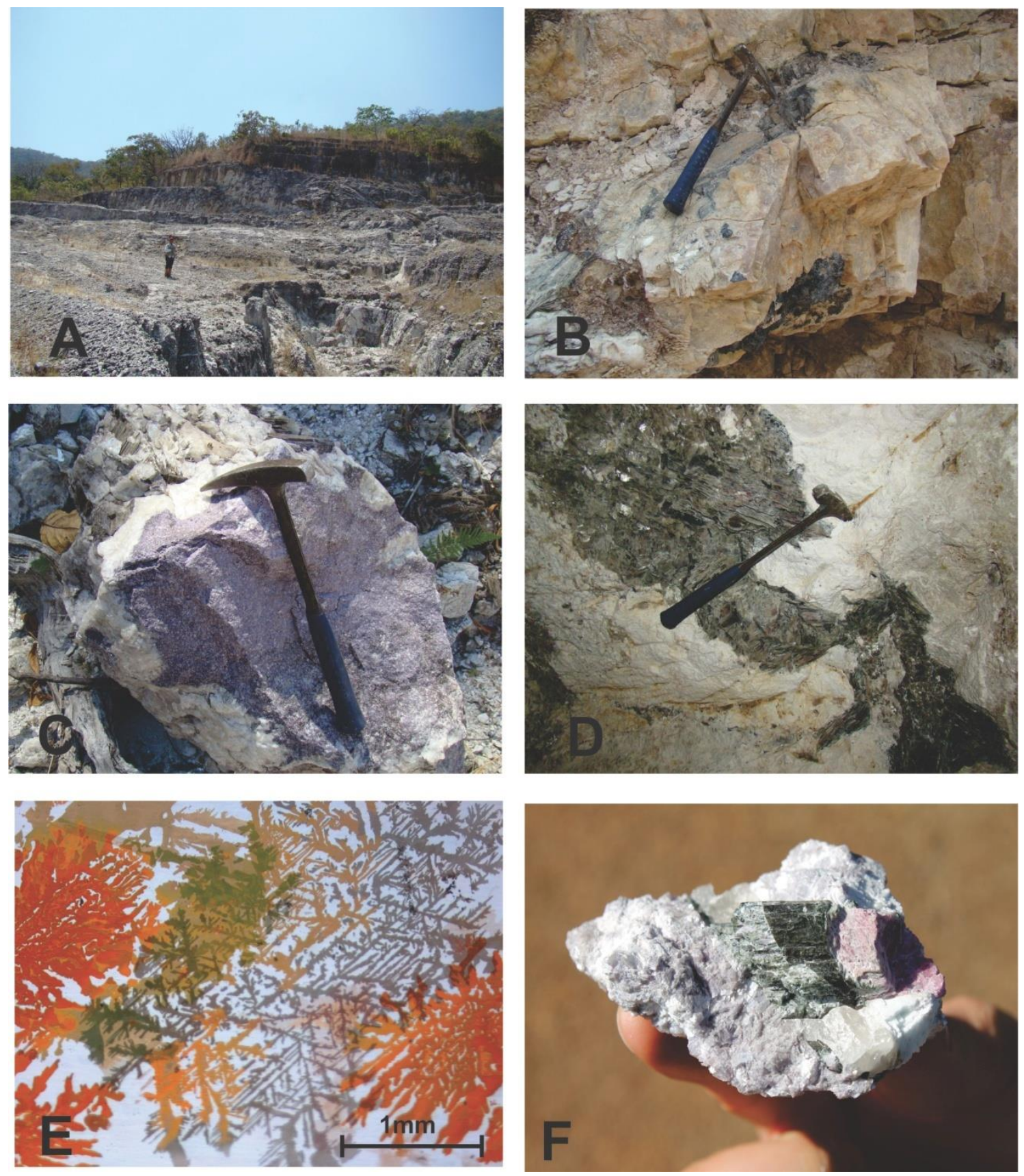

Figure 2.4: Pegmatites explored for tourmaline. (A): Exposed area of the Marimbondo pegmatite. (B): Quartz block with centimetric crystals of schorl in the Berilão pegmatite. (C): Aggregate of lepidolites in block of quartz. (D): "Books" of muscovite surrounded by kaolin in the Zé do Fole pegmatite. (E): Iron oxides as inclusions in muscovite. (F): Elbaite known as "watermelon tourmaline" associated with purple lepidolite and white albite. 
Muscovite is another common mineral in the tourmaline-bearing pegmatites, occurring as silver aggregates of centimetric size in the external wall zone or as megacrystal plates up to thirty centimeters in diameter (figure 2.4). This muscovite plates contain many inclusions of hematite, tourmaline and diaspore (figure 2.4). The muscovite plates are yellow in color when in contact with minerals from the internal zone.

Black tourmaline is usually present in the wall zones as isolated crystals or in agglomerates, especially in the Berilão pegmatite, where this mineral occurs as abundant large crystals (up to $40 \mathrm{~cm}$ ) from the wall zone to the quartz core (figure 2.4). Tourmaline becomes more colorful and zoned in the northern pegmatites, featuring a wide range of colors, including black, dark or light green, and varied shades of pink. Some rare millimetric, colorless to light green crystals were also observed. In the southern bodies, the tourmaline crystals are mainly black, dark green and dark blue, with a small number of light green and blue samples. Zoned tourmaline crystals are more common in the northern bodies. This zonation can feature either a black core and a pink or green edge or a pink core and a green edge, known as "watermelon tourmaline". Tantalite and Mn oxides were identified as inclusions or as tiny grains on the surface of some elbaite crystals.

According to the classification of Henry et al. (2011) (figure 2.5), the chemistry of the tourmaline crystals (table 2.3) can be divided into three primary groups: alkali, calcic and x-vacant. The black tourmaline was classified mainly as schorlite, and a small number of crystals, which are in contact with the country rock, were classified as dravite. The colorful tourmaline crystals are divided into three types: elbaite (the most common colorful tourmaline in the study area), rossmanite and liddicoatite (rare occurrence in the northern group). Frequently, a great number of tourmalines contain the prefix "fluor", due to their high fluorine content in the W crystallographic site.

Lepidolite was found in both pegmatite groups, but it was more prominent in the northern group. This type of mica often forms large blocks of millimeter-scale crystals (figure 2.4), with a purple-grey to light purple color. Relatively large lepidolite blocks are found in the Córrego das Pedras pegmatite. This mineral is almost always associated with blocks of quartz, albite and colorful tourmaline, and this assemblage represents a typical external zone mineral association. Zoned crystals, with a muscovite core and a lepidolite edge, were found in the Boanerges, Marimbondo and Zé do Fole pegmatites. Chemical data from different lepidolite crystals from different pegmatites indicate a 
trilithionite composition, according to the Tischendorf (1997) classification (table 2.4, figure 5).

Albite is common only in the northern pegmatite group and occurs as a white or slightly blue mass or as cleavelandite-type tabular crystals. In the southern group, albite was only found in the Jóia da Mata pegmatite, close to a green tourmaline and quartz contact.

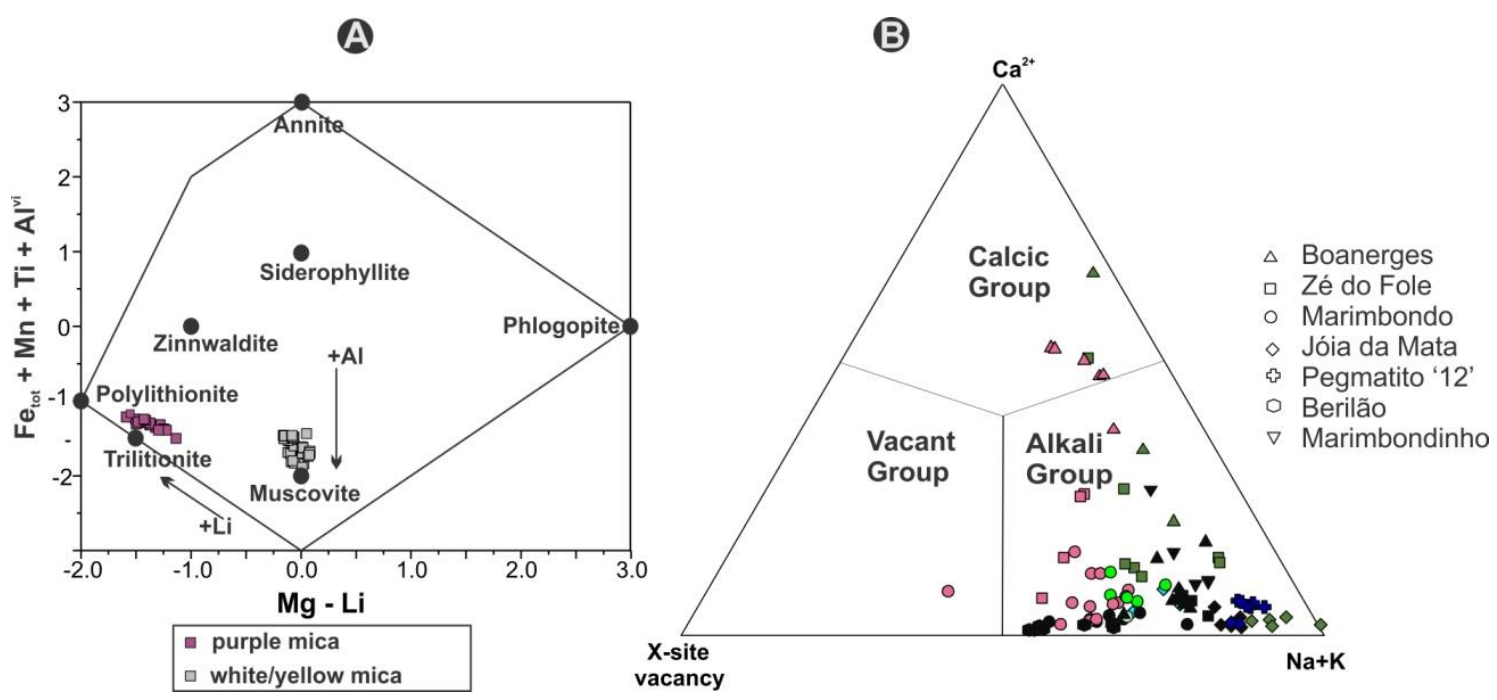

Figure 2. 5: Mica and tourmaline classification diagrams. (A) Simplified diagram from Tischendorf (1997), the black circles correspond to final members of mica group, values in apfu. (B): Tourmaline groups from Henry et al. (2011). The colors of the symbols are representative of the color of the crystals.

Spessartite crystals of millimetric size are strongly present in heavy grains concentrates separated from samples of the external zone of the Boanerges pegmatite. This type of garnet indicates a higher Mn content compared to the almandine crystals in beryl-bearing pegmatites.

Milky and white-green beryl crystals, up to $20 \mathrm{~cm}$ long, were collected from the Boanerges and Marimbondo pegmatites. In the Marimbondo pegmatite, some beryl fragments show a slightly pink color. Beryl crystals from bodies with aquamarine mineralization show lower Fe and higher alkalis contents (table 2.4).

Two fragments of white spodumene were collected in contact with albite and pink tourmaline in the Zé do Fole pegmatite. Pink montmorillonite, called "soap" by the artisanal miners, was collected in small isolated nodules from Marimbondo, most likely related to more differentiated zones. Similar relationships were described by Foord et al. (1986) in the Pala pegmatite district in California and by Dill et al. (2011) in the Alto dos Quintos mine in the state of Rio Grande do Norte. Prismatic smoky quartz with one 
of the ends preserved was collected from the Marimbondo mining site. Several of these smoky quartz crystals contain a great number of small translucent pink tourmaline crystals on their surfaces. Brown quartz was found in a small crevasse in the Zé do Fole pegmatite at in contact with albite, colorful zoned tourmaline and lepidolite.

Table 2. 3: Representative composition of tourmaline crystals.

\begin{tabular}{cccccccc}
\hline & Dravite & Schorl & $\begin{array}{c}\text { F-Elbaite } \\
\text { (blue) }\end{array}$ & $\begin{array}{c}\text { Pink } \\
\text { elbaite }\end{array}$ & $\begin{array}{c}\text { F-Elbaite } \\
\text { (Green) }\end{array}$ & $\begin{array}{c}\text { F- } \\
\text { Liddicoatite } \\
\text { (Pink) }\end{array}$ & $\begin{array}{c}\text { Pink } \\
\text { rossmanite }\end{array}$ \\
\hline $\mathrm{SiO}_{2}$ & 38.64 & 34.57 & 36.74 & 37.94 & 37.63 & 37.24 & 37.94 \\
$\mathrm{TiO}_{2}$ & 0.38 & 0.38 & 0 & 0.02 & 0.06 & 0 & 0.00 \\
$\mathrm{Al}_{2} \mathrm{O}_{3}$ & 31.19 & 33.49 & 40.18 & 41.64 & 40.82 & 41.5 & 40.83 \\
$\mathrm{FeO}^{\ddagger}$ & 4.42 & 12.46 & 2.19 & 0.01 & 1.39 & 0 & 0.09 \\
$\mathrm{MnO}$ & 0.00 & 0.36 & 1.39 & 0.10 & 0.47 & 0.18 & 0.98 \\
$\mathrm{MgO}$ & 8.51 & 2.52 & 0.02 & 0.01 & 0.01 & 0.02 & 0.06 \\
$\mathrm{CaO}$ & 0.54 & 0.37 & 0.22 & 0.28 & 0.70 & 3.11 & 0.44 \\
$\mathrm{Na} 2 \mathrm{O}$ & 2.45 & 2.26 & 2.18 & 2.00 & 2.10 & 1.02 & 1.19 \\
$\mathrm{~K} 2 \mathrm{O}$ & 0.08 & 0.05 & 0.03 & 0.02 & 0.02 & 0.02 & 0.06 \\
$\mathrm{~F}$ & 0.48 & 0.28 & 1.12 & 0.98 & 1.00 & 1.1 & 0.84 \\
$\mathrm{H}_{2} \mathrm{O}^{*}$ & 3.54 & 3.45 & 3.22 & 3.36 & 3.34 & 3.33 & 3.39 \\
$\mathrm{~B}_{2} \mathrm{O}_{3} *$ & 10.92 & 10.39 & 10.87 & 11.08 & 11.07 & 11.17 & 10.99 \\
$\mathrm{Li}_{2} \mathrm{O}^{*}$ & 0.78 & 0.22 & 1.67 & 2.10 & 2.02 & 2.5 & 2.05 \\
$\mathrm{Total}$ & 101.93 & 100.8 & 99.83 & 99.05 & 100.7 & 101.19 & 98.87 \\
$\mathrm{O}^{2} \mathrm{~F}$ & -0.20 & -0.12 & -0.47 & -0.41 & -0.50 & -0.55 & -0.42 \\
\hline
\end{tabular}

Formula contents

\begin{tabular}{|c|c|c|c|c|c|c|c|}
\hline $\mathrm{Ca}$ & 0.09 & 0.07 & 0.04 & 0.05 & 0.12 & 0.52 & 0.08 \\
\hline $\mathrm{Na}$ & 0.76 & 0.73 & 0.68 & 0.61 & 0.64 & 0.31 & 0.37 \\
\hline $\mathrm{K}$ & 0.02 & 0.01 & 0.01 & 0.00 & 0.00 & 0.00 & 0.01 \\
\hline$\square$ & 0.14 & 0.19 & 0.28 & 0.34 & 0.24 & 0.16 & 0.55 \\
\hline$\sum X$ & 1.00 & 1.00 & 1.00 & 1.00 & 1.00 & 0.99 & 1.00 \\
\hline $\mathrm{Al}$ & 0.00 & 0.38 & 1.44 & 1.66 & 1.47 & 1.41 & 1.63 \\
\hline $\mathrm{Ti}$ & 0.05 & 0.05 & 0.00 & 0.00 & 0.00 & 0.00 & 0.00 \\
\hline $\mathrm{Mg}$ & 1.87 & 0.63 & 0.01 & 0.00 & 0.00 & 0.00 & 0.01 \\
\hline $\mathrm{Mn}$ & 0.00 & 0.05 & 0.19 & 0.01 & 0.06 & 0.02 & 0.13 \\
\hline $\mathrm{Fe}$ & 0.59 & 1.74 & 0.29 & 0.00 & 0.18 & 0.00 & 0.01 \\
\hline $\mathrm{Li}$ & 0.50 & 0.15 & 1.07 & 1.32 & 1.28 & 1.56 & 1.21 \\
\hline$\sum \mathrm{Y}$ & 3.00 & 3.00 & 3.00 & 2.99 & 2.99 & 2.99 & 3.00 \\
\hline $\mathrm{Al}$ & 5.85 & 6 & 6 & 6 & 6 & 6 & 6 \\
\hline $\mathrm{Mg}$ & 0.15 & - & - & - & - & - & - \\
\hline $\mathrm{Si}$ & 6.15 & 5.78 & 5.87 & 5.95 & 5.91 & 5.80 & 6.01 \\
\hline $\mathrm{Al}$ & - & 0.22 & 0.13 & 0.05 & 0.09 & 0.21 & - \\
\hline$B$ & 3 & 3 & 3 & 3 & 3 & 3 & 3 \\
\hline $\mathrm{F}$ & 0.24 & 0.15 & 0.57 & 0.49 & 0.50 & 0.54 & 0.42 \\
\hline $\mathrm{OH}$ & 3.76 & 3.85 & 3.43 & 3.51 & 3.50 & 3.46 & 3.58 \\
\hline
\end{tabular}


Table 2. 4: Representative composition of selected minerals from the tourmaline-bearing pegmatites.

\begin{tabular}{|c|c|c|c|}
\hline & Trilitionite & Spessartite & White beryl \\
\hline $\mathrm{SiO}_{2}$ & 51.58 & 37.62 & 64.01 \\
\hline $\mathrm{TiO}_{2}$ & 0 & 0.02 & \\
\hline $\mathrm{Al}_{2} \mathrm{O}_{3}$ & 23.82 & 19.95 & 19.87 \\
\hline $\mathrm{FeO}$ & 0 & 15.01 & 0.17 \\
\hline $\mathrm{MgO}$ & 0 & 0.04 & \\
\hline $\mathrm{MnO}$ & 0.84 & 27.57 & 0.02 \\
\hline $\mathrm{CaO}$ & 0.02 & 0.52 & \\
\hline $\mathrm{Li}_{2} \mathrm{O}^{*}$ & 5.25 & & \\
\hline $\mathrm{Na}_{2} \mathrm{O}$ & 0.32 & & 0.93 \\
\hline $\mathrm{K}_{2} \mathrm{O}$ & 11.56 & & 0.02 \\
\hline $\mathrm{Rb}_{2} \mathrm{O}$ & 0.56 & & 0 \\
\hline $\mathrm{Cs}_{2} \mathrm{O}$ & 0.15 & & 0.17 \\
\hline F & 7.74 & & \\
\hline $\mathrm{H} 2 \mathrm{O}^{*}$ & 0.81 & & \\
\hline $\mathrm{O}=\mathrm{F}$ & 3.26 & & \\
\hline \multirow[t]{2}{*}{ total } & 99.51 & 100.75 & 85.19 \\
\hline & \multicolumn{2}{|c|}{ Formula contents } & \\
\hline $\mathrm{Si}$ & 6.898 & 3.068 & 5.845 \\
\hline $\mathrm{Ti}$ & 0 & 0 & \\
\hline $\mathrm{Al}$ & 3.755 & 1.919 & 2.138 \\
\hline $\mathrm{Fe}$ & 0 & 1.023 & 0.013 \\
\hline $\mathrm{Mg}$ & 0 & 0.005 & \\
\hline $\mathrm{Mn}$ & 0.095 & 1.905 & 0.002 \\
\hline $\mathrm{Ca}$ & 0.003 & 0.045 & \\
\hline $\mathrm{Li}$ & 2.825 & & \\
\hline $\mathrm{Na}$ & 0.084 & & 0.165 \\
\hline $\mathrm{K}$ & 1.972 & & 0.001 \\
\hline $\mathrm{Rb}$ & 0.048 & & 0 \\
\hline Cs & 0.009 & & 0.002 \\
\hline $\mathrm{F}$ & 3.273 & & \\
\hline $\mathrm{OH}$ & 0.727 & & \\
\hline
\end{tabular}

Table 2. 5: List of minerals found in the tourmaline-bearing pegmatites.

\begin{tabular}{|c|c|c|c|c|}
\hline \multicolumn{5}{|c|}{ Tourmaline-bearing pegmatites } \\
\hline \multirow{4}{*}{$\begin{array}{c}\text { Quartz } \\
\text { Schorl } \\
\text { Mn oxide }\end{array}$} & \multirow{4}{*}{$\begin{array}{c}\text { Microcline } \\
\text { Blue elbaite } \\
\text { Hematite }\end{array}$} & Southern group & \multirow{4}{*}{$\begin{array}{c}\text { Kaolin } \\
\text { Muscovite }\end{array}$} & \multirow{4}{*}{$\begin{array}{l}\text { Dravite } \\
\text { Trilitionite }\end{array}$} \\
\hline & & Albite & & \\
\hline & & Green elbaite & & \\
\hline & & & & \\
\hline \multirow{3}{*}{ Quartz } & \multirow{3}{*}{ Microcline } & Northern group & \multirow{3}{*}{ Kaolin } & \\
\hline & & Albite & & Pink \\
\hline & & & & montmorillonite \\
\hline Dravite & Schorl & Green elbaite & Pink elbaite & Pink liddicoatite \\
\hline Green liddicoatite & Pink rossmanite & Muscovite & Trilitionite & Mn oxide \\
\hline Hematite & Tantalite & Spodumene & Spessartite & White beryl \\
\hline Pink Beryl & Diaspore & & & \\
\hline
\end{tabular}




\subsubsection{Barren pegmatites}

Dykes of barren pegmatites with an exposed area of tens of meters and a NE-SW orientation are scattered throughout a wide area in the studied region. Although a large portion of these bodies is totally kaolinized, some of them are well exposed and have a well-preserved association of minerals. A special outcrop is located just over twenty kilometers northeast of the Levantina Quarry (figure 2.2) in a cut of the highway TO498 (figure 2.6), where several dykes of granitic composition crosscut a paragneiss over an extent of tens of meters. These intrusions, whose thickness varies from a few centimeters to more than four meters, comprise three facies: mica-poor and mica-rich leucogranites and pegmatite (figure 2.6). The thicker pegmatite dykes are not concordant and have a pink color with some white shades. The essential minerals are quartz, microcline and albite $\left(\mathrm{An}_{3-7}\right)$, approximately in the same proportion. The potassic feldspar commonly displays cross-hatched twinning and graphic texture evident in thin section (figure 2.6) and in hand samples. Mica is rare, in some cases forming clusters of muscovite and rare biotite. The most common accessory minerals are almandine, which can form some crystals with well-preserved faces, and more rarely green-colored fluorapatite as isolated euhedral crystals. Iron oxides are widespread in the surface of microcline and sometimes in biotite, which can account for the rock color. The main alteration phase found is sericite, which can be very noticeable in specific occurrences. With the help of EDS analysis by electron microprobe, crystals of zircon and Fe-columbite were identified. In some places, centimetric miarolitic cavities host a large amount of euhedral crystals of muscovite and quartz.

The smaller dykes, up to one meter thick, are discordant or concordant, have a predominately white color, with localized pink shades when in contact with the larger granitic mass (figure 2.6). The basic mineralogy of the smaller dikes is more than $90 \%$ quartz and plagioclase (albite/oligoclase), with K-feldspar and micas in minor proportions. In some dykes, typical pegmatite zoning is formed by K-feldspar with graphic intergrowth in the external zone, larger feldspars, quartz and muscovite in the intermediate zone, and massif quartz in the core. Some quartz veinlets cut the dykes and the largest granitic white masses.

The intrusions described above form a complex network of concordant to discordant dykes of granite/pegmatite containing many paragneiss enclaves. The contact 
between the intrusions and the country-rock is always sharp, with the edges of the intrusions exposing a rectilinear, sometimes meandering, contact line. Some aspects of digestion of the country-rock were observed in the enclaves and near the contact line (figure 2.6).
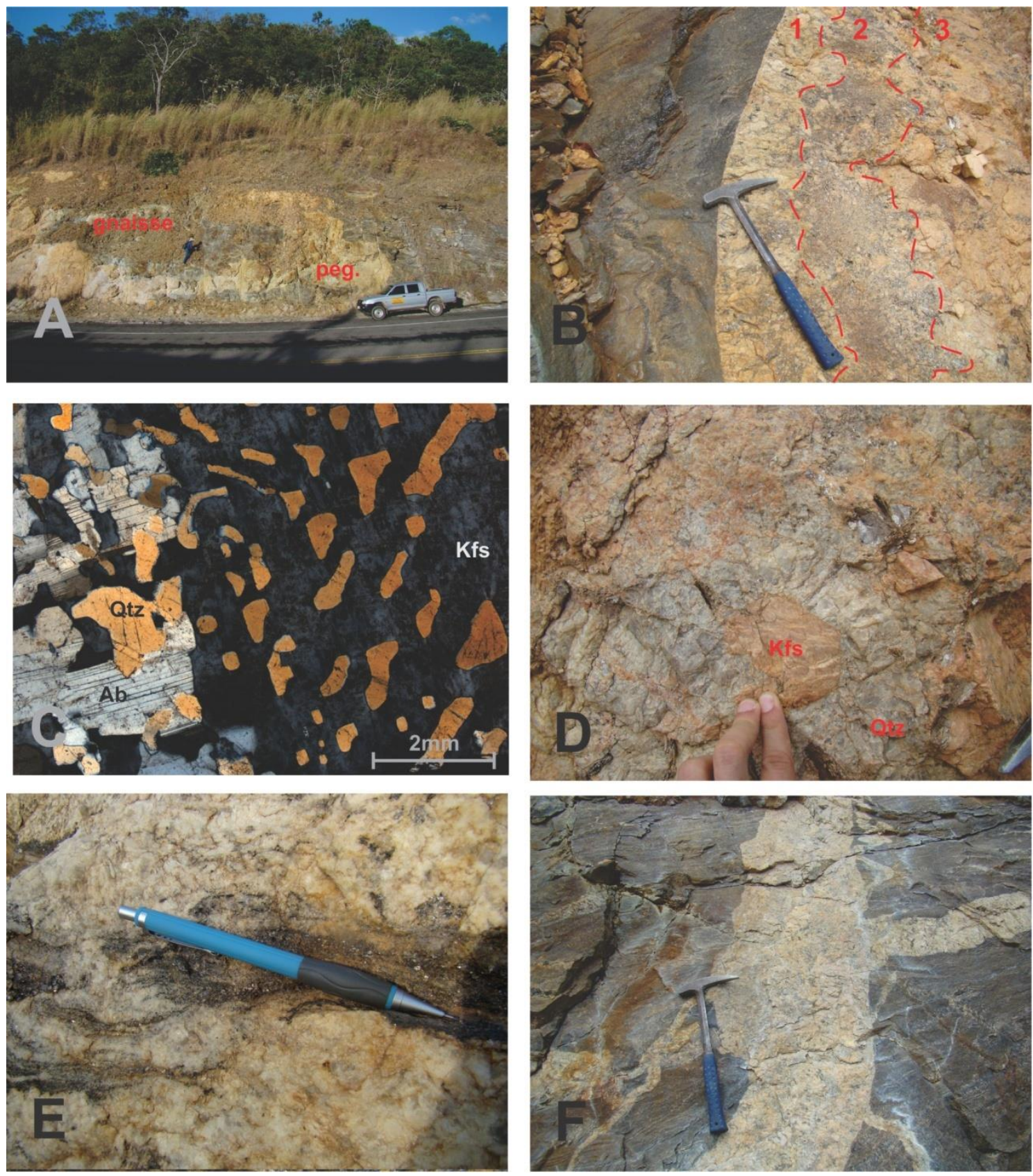

Figure 2. 6: Simple pegmatites. (A): Outcrop showing light pegmatite intrusion in dark paragneiss country rock. (B): Detail of the contact paragneiss-pegmatite and the three facies of the simple pegmatite, 1: coarse-grain leucogranite, 2: coarse-grain leucogranite with abundant mica, 3: pegmatitic facies. (C): Photomicrograph of graphic texture. (D) Pegmatitic texture with K-feldspar and quartz. (E): Evidences of digestion in paragneiss. (F): Concordant and discordant minor dykes. 


\subsubsection{Country rock of the pegmatites and alterations}

\section{MINERALIZED PEGMATITES}

Due to the lack of good-quality outcrops and limited exposure of rocks, the contact relationships between the mineralized pegmatites and the country rocks were not clearly observed. In the Marimbondinho pit, part of a pegmatite dike is in discordant contact with an altered and red-colored quartz-biotite-muscovite schist with a strong crenulation cleavage. The country rock of this pegmatite body contains a large amount of fine dravite grains near the contact, indicating metasomatic reactions between these rocks (figure 2.7), whereas only a few centimeters away from the pegmatite, no dravite crystals are formed. In the Onça mine pit, the wall zone of the pegmatite is in contact with an extreme altered granitic rock, consistent with regional granitic rocks described in the area by Araújo-Filho et al. (2017). Although it is not possible to visually examine the contact between the pegmatite and the country rock, blocks and scattered outcrops of different lithotypes were observed near several pegmatite bodies. Fragments of strongly weathered mica schists were found in the tailing area of Córregos das Pedras and Jóia da Mata pegmatites. In the northern group region, tourmaline-bearing pegmatites, mica schists, quartzite and calc-siliciclastic rocks are the components of the pegmatite-hosting valleys and hills. Schist and quartzite are found on slopes close to the Marimbondo, Marimbondinho and Berilão pegmatites.

The calc-siliciclastic rocks are the main country rocks and are found close to the other pegmatite bodies. According to Araújo Filho et al. (2017), these calc-silicicatic rocks are related to the Serra da Mesa Group, while other metasedimentary rocks could be associated with the Ticunzal Formation. The Onça pegmatite is most likely intrusive in peraluminous granites of the Aurumina Suite. In literature, the metasedimentary units (Ticunzal and Serra da Mesa formations) are metamorphozed in amphibolites grade. 


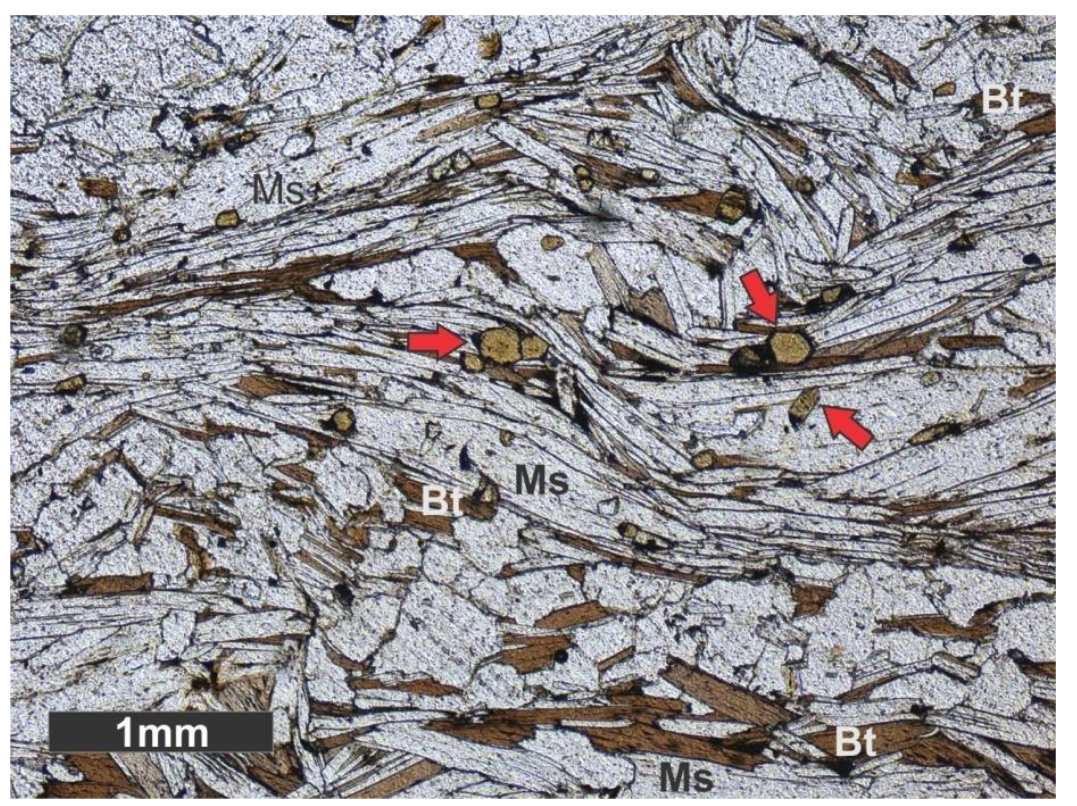

Figure 2. 7: Photomicrograph of dravite-bearing schist. The metasomatic tourmaline crystals at the pegmatite contact are indicative by red arrows. Bt: biotite, Ms: muscovite.

\section{BARREN DYKES}

The country rocks of the barren dykes are the metasedimentary units Ticunzal and Serra da Mesa. Only in the "17" pegmatite is possible visualize a good contact between country rock and pegmatite. In " 17 ” pegmatite the country rock is probably the Ticunzal Formation (Araújo Filho et al. 2017), containing quartz, biotite, strongly sericitized plagioclase $\left(\mathrm{An}_{20-22}\right)$ and potassium feldspar. The accessory minerals include muscovite, apatite, zircon, monazite, and ilmenite. The emplacement of this pegmatite dykes described above produced contact metamorphism limited by the size of the intrusions, forming alteration halos just over a few tens of centimeters. The exception is the completely altered enclaves occurring as meter-scale blocks immersed in the intrusions. Later hydrothermal alteration affected the intrusion and the country rock.

There are four zones $-1,1 \mathrm{~A}, 2$ and 3 - that can be described as the result of thermal metamorphism (figure 2.8). The zones 1 and $1 \mathrm{~A}$ are the closest to the intrusion and consequently were affected by a higher thermal gradient in relation to the unchanged rock. These two zones are composed mainly of Fe- and K-rich hornblende and clinopyroxene (figure 2.9), followed by minor titanite and allanite. Fluorite and carbonates are secondary minerals, products of allanite and amphibole alteration. 
Amphibole and pyroxene co-exist mostly in zone 1. The pyroxene hedenbergite in zone 1 changes to diopside in zone $1 \mathrm{~A}$, indicating an increase in $\mathrm{Mg}$ (figure 2.9). The concentration of pyroxene, which is above $70 \%$ by volume in zone $1 \mathrm{~A}$, and the scarcity of amphibole suggest there were portions in the protolith with higher concentrations of iron-magnesium minerals. To a lesser extent, aggregates of euhedral and subhedral titanite rich in fluorine formed, most likely at the expense of former ilmenite. Allanite crystals with shades of yellow and brown are distributed in zones 1 and $1 \mathrm{~A}$ in contact mainly with plagioclase, which in this area contains significantly more calcium $\left(\mathrm{An}_{34-}\right.$ 47). Due to the expansion of the crystalline structure caused by metamictization and hydration, allanite produces a visible halo of radiation, as well as radial fracture patterns around the crystal.

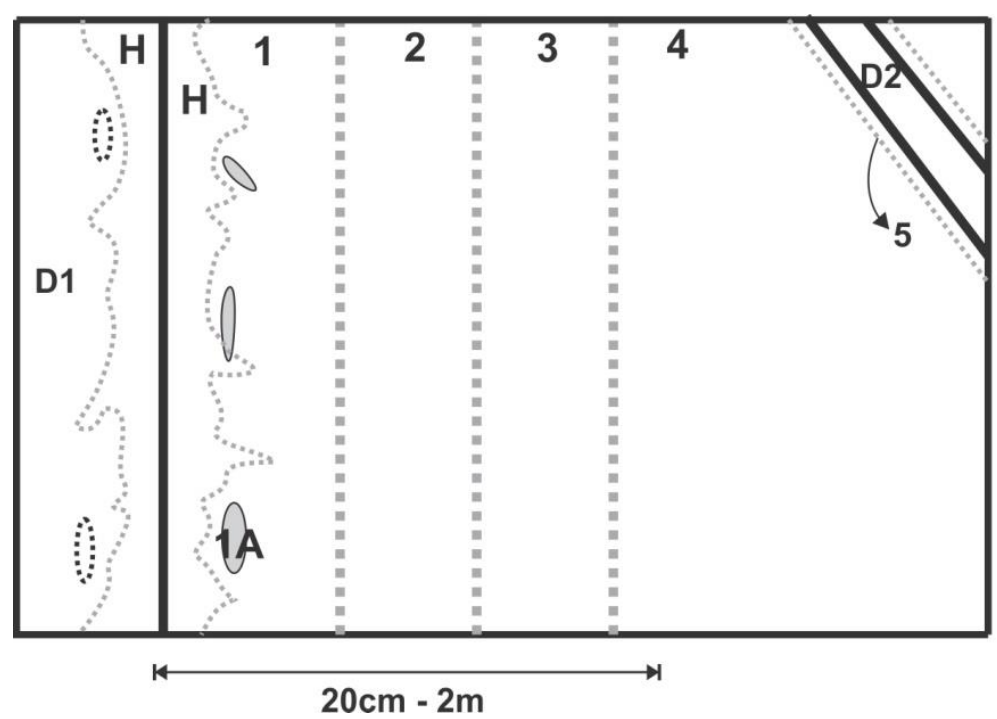

H: Hydrothermal alteration

Alteration zones

$(1,1 \mathrm{~A}, 2,3)$

4: Unaltered coutry-rock

5: Zone with $\mathrm{Nb}-\mathrm{Ti}-\mathrm{Ta}$ oxides

Simple Pegmatite Intrusions (D1 e D2)

Miarolitic cavities

Lithologic contact

Limit of alterations

Figure 2. 8: Scheme showing the relationship between the pegmatitic intrusion and the associated alteration halo.

Zones 2 and 3 are farther from the pegmatite than zones 1 and 1A. Pyroxene is absent in zones 2 and 3 because these zones received less heat from the intrusion. Thus, there was not enough heat to alter the amphibole, which in turn occurs in a small number of magnesian hornblende crystals only in zone 2. Biotite occurs as the main Fe and $\mathrm{Mg}$ silicate in zone 3 and co-exists in a smaller proportion of approximately one percent with hornblende in zone 2. Titanite occurs as scattered grains in zones 2 and 3 and presents more marked pleochroism than the crystals from zones 1 and 1A. Because of the replacement, $(\mathrm{Al}, \mathrm{Fe})^{3+}+(\mathrm{F}, \mathrm{OH})-=\mathrm{Ti}^{4+}+\mathrm{O}^{2-}$, the contents of $\mathrm{Al}$ and $\mathrm{F}$ are noticeably lower, whereas the content of titanium (figure 2.9) is the highest (Nesse 
2000). In the zone 3, the association between biotite and a Mn-rich almandine is very common.

Zone 5 occurs in the area of contact between the country rock and the previously described small dykes rich in albite. This zone is approximately two centimeters wide and shows concentrations of polycrase-( $\mathrm{Y}$ ) and rutile enriched in $\mathrm{Nb}$ and $\mathrm{Ta}$, called ilmenorutile and formed by a metasomatic process characteristic of this type of dyke (table 2.6). The enrichment of $\mathrm{Nb}$ and $\mathrm{Ta}$ in the rutile increases with the proximity of the intrusion. These two elements of high charge replace titanium in the mineral according to the equation $2 \mathrm{Ti}^{4+}=(\mathrm{Ta}, \mathrm{Nb})^{5+}+\mathrm{Fe}^{3+}$ (Beurlen et al. 2008). The $\mathrm{TiO}_{2}$ values of the rutile crystals more distant from the intrusion are higher than $90 \%$. As described earlier, the smaller dykes contain isolated crystals of Fe-columbite, which reinforces the saturation in $\mathrm{Nb}$ and $\mathrm{Ta}$ on this evolved rock, while the source of $\mathrm{Ti}$ is probably related to the destabilization of biotite and/or ilmenite in the paragneiss.
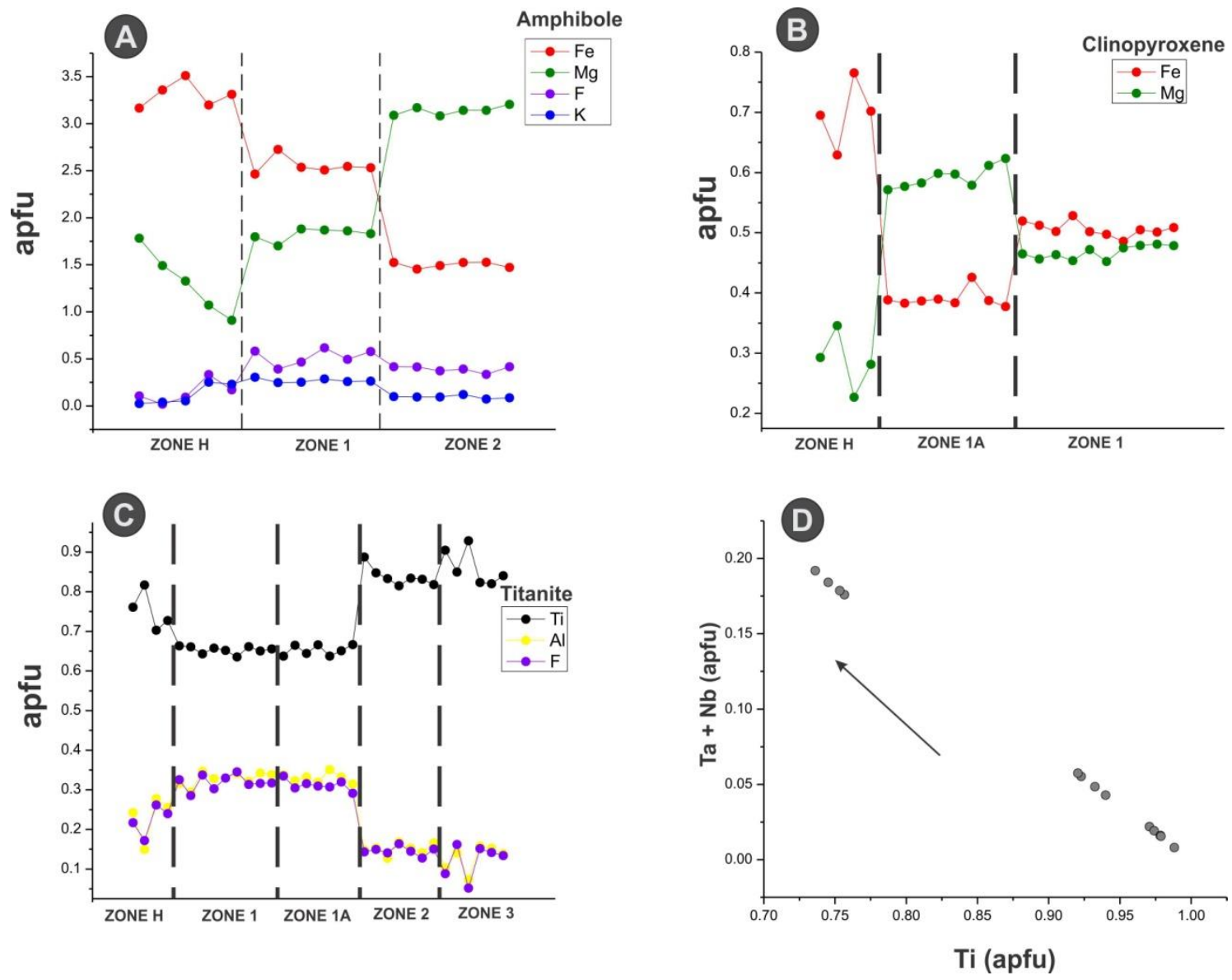

Figure 2. 9: Element distribution (in apfu) in metasomatic phases. (A, B, C): Amphibole, clinopyroxene and titanite. (D): Negative correlation between $\mathrm{Ta}+\mathrm{Nb} v \mathrm{si}$ in rutile and ilmenorutile; the arrow indicates the direction of paragneiss-pegmatite contact. 
After the contact metamorphism caused by the intrusions of the simple pegmatite dykes, a hydrothermal phase affected both the pegmatite and the country rock. The hydrothermal process caused silicification in both rocks and filled fractures with the major mineral phases of this event, which are quartz and sulphides. The main sulphide is a late-formed pyrrhotite, present as anhedral crystals that are present in fractures and become dispersed in zone 1. Small amounts (no more than one percent) of chalcopyrite crystals were identified. Garnet crystals, in concentrations between 5 and 30\%, are also common in the samples from the hydrothermalized area and have higher Ca contents in relation to the garnet crystals from zone 3 (figure 2.10). In the hydrothermal garnet, the concentration of molecules of almandine and grossular is almost the same (28 to $40 \%$ ), with a significant content of spessartine (20 to $24 \%$ ).

Table 2. 6: Representative composition of metasomatic oxides in the paragneiss-pegmatite contact.

\begin{tabular}{|c|c|c|c|c|}
\hline & Rutile I & Ilmenorutile & Ilmenorutile II & Y-Polycrase \\
\hline $\mathrm{Ta} 2 \mathrm{O} 5$ & 0.23 & 6.03 & 14.21 & 9.99 \\
\hline $\mathrm{Nb} 2 \mathrm{O} 5$ & 1.25 & 5.35 & 16.44 & 21.21 \\
\hline $\mathrm{TiO} 2$ & 97.56 & 85.57 & 61.34 & 21.14 \\
\hline $\mathrm{U} 3 \mathrm{O} 8$ & & & & 9.67 \\
\hline $\mathrm{ThO} 2$ & & & & 3.27 \\
\hline $\mathrm{Y} 2 \mathrm{O} 3$ & & & & 11.35 \\
\hline $\mathrm{Gd} 2 \mathrm{O} 3$ & & & & 1.30 \\
\hline Dy2O3 & & & & 2.98 \\
\hline Er2O3 & & & & 1.88 \\
\hline $\mathrm{MnO}$ & & & & 0.20 \\
\hline $\mathrm{Fe}_{2} \mathrm{O}_{3}$ & 0.86 & 3.5 & 8.89 & 2.88 \\
\hline $\mathrm{CaO}$ & & & & 2.49 \\
\hline \multirow[t]{2}{*}{ Total } & 99.81 & 100.1 & 99.98 & 86.89 \\
\hline & & Formula contents & & \\
\hline $\mathrm{Ta}$ & 0 & 0.022 & 0.060 & 0.167 \\
\hline $\mathrm{Nb}$ & 0.007 & 0.033 & 0.116 & 0.589 \\
\hline $\mathrm{Ti}$ & 0.988 & 0.923 & 0.757 & 0.977 \\
\hline $\mathrm{U}$ & & & & 0.126 \\
\hline $\mathrm{Th}$ & & & & 0.046 \\
\hline $\mathrm{Y}$ & & & & 0.612 \\
\hline $\mathrm{Gd}$ & & & & 0.107 \\
\hline Dy & & & & 0.104 \\
\hline $\mathrm{Er}$ & & & & 0.065 \\
\hline $\mathrm{Mn}$ & & & & 0.011 \\
\hline $\mathrm{Fe}^{3}$ & 0.004 & 0.018 & 0.052 & 0.140 \\
\hline $\mathrm{Ca}$ & & & & 0.163 \\
\hline
\end{tabular}

Number of cations on the basis of 2 Ofor rutile and ilmenorutile and 6 O for polycrase (Y).

The decrease in the volume of pyroxenes in the hydrothermalized area, when this overlaps portions of the country rock, can be explained by the action of hydrothermal fluids that hydrate the hedenbergitic pyroxene, giving rise to Fe-rich hornblende and Feactinolite in the form of acicular crystals. The hydrothermal process caused intense 
oxidation in crystals of garnet and amphibole. This is evident by the large amount of iron oxides on the edges and fractures of the minerals. The titanate crystals from this area exhibit higher $\mathrm{Ti}$ and lower $\mathrm{Al}$ and $\mathrm{F}$ contents (figure 2.9).

The last stage of alteration present in the minor intrusions and the country rock is the formation of sulfates. With the meteoric water percolation in fractures present in the intrusion and in the paragneiss, the pre-existing sulphides were hydrated, producing minerals such as pickeringite $-\mathrm{Mg} \mathrm{Al} 2\left(\mathrm{SO}_{4}\right)_{4} \cdot 22 \mathrm{H}_{2} \mathrm{O}$ and alunogen $-\mathrm{Al}_{2}\left(\mathrm{SO}_{4}\right)_{3} \cdot 17 \mathrm{H}_{2} \mathrm{O}$.

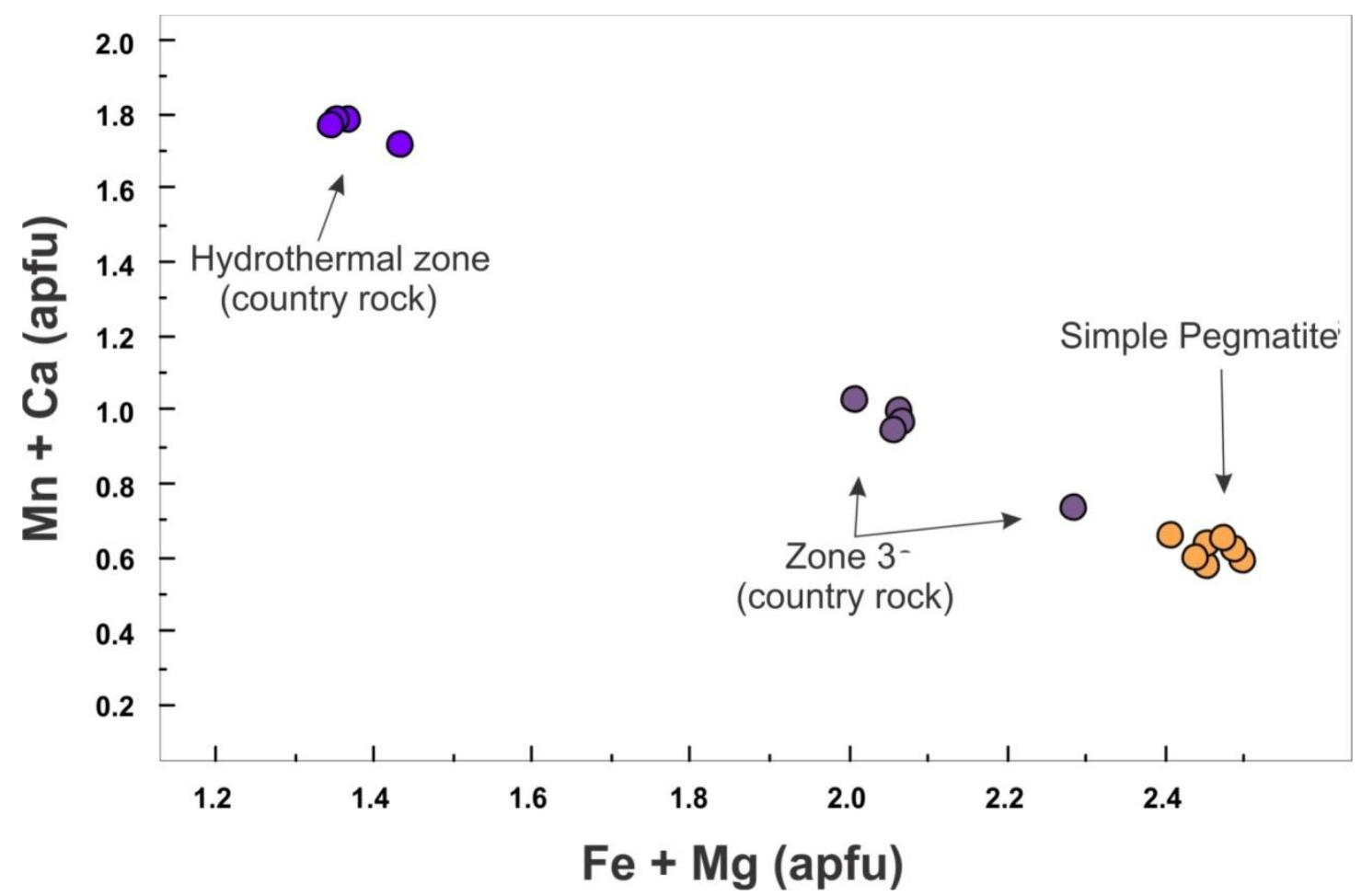

Figure 2. 10: Chemical composition of garnet crystals showing the difference between the country rock metasomatic garnet and the pegmatite garnet.

A possible origin for the calc paragenesis is related to calcsilicate rocks from Serra da Mesa Group, outcropping near (30-50 meters) this location. The thermal metamorphism generated a mass transference by fluid circulation in a small scale; the Ticunzal formation and Serra da Mesa Group are stratigraphically in contact in many locations of the regional area, so, after the intrusion, the $\mathrm{Ca}$ component removed from Serra da Mesa rocks can be re-mobilized to the contact with Ticunzal formation. 
Table 2. 7: Representative composition of some metasomatic minerals.

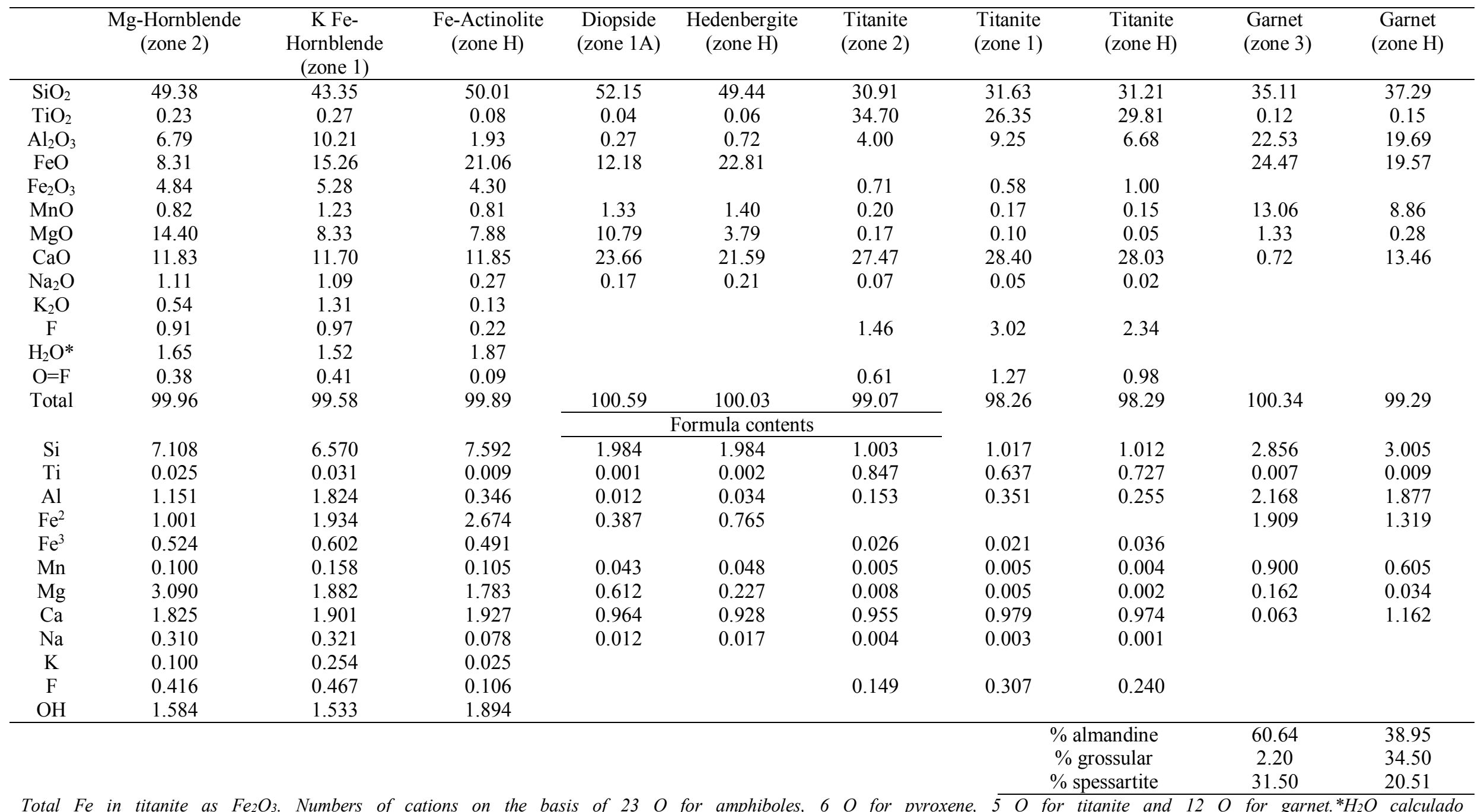




\subsubsection{Geochronological data}

Geochronological information on the pegmatites in this study is scarce, and all attempts to date them have failed using the zircon $\mathrm{U}-\mathrm{Pb}$ method because of the scarcity of this mineral and metamict crystals. However, knowledge of the age of the pegmatites is very important for comparison with the age of the probable parental granite. An option for $\mathrm{U}-\mathrm{Pb}$ dating is the use of the monazite that was identified in the Boanerges pegmatite. Brown greenish crystals of monazite of the kaolinized wall zone of the body were dated to $519.9 \pm 2.8 \mathrm{Ma}$ (table 2.8, figure 2.11 ).

Table 2. 8: U-Pb values and the calculated age by the chemical dating.

\begin{tabular}{cccccccc}
\hline & ${ }^{206} \mathrm{~Pb} /{ }^{204} \mathrm{~Pb}$ & ${ }^{207} \mathrm{~Pb} /{ }^{235} \mathrm{U}$ & $1 \sigma \%$ & ${ }^{206} \mathrm{~Pb} /{ }^{238} \mathrm{U}$ & $1 \sigma \%$ & $\mathrm{Rho}$ & $\begin{array}{c}\text { Idade } \\
{ }^{207} \mathrm{~Pb} /{ }^{235} \mathrm{U}\end{array}$ \\
\hline MZ20 & 411 & 1.662 & 2.58 & 0.0785 & 1.26 & 0.49 & 994 \\
$\mathrm{MZ18}$ & 437 & 1.106 & 1.35 & 0.0948 & 0.86 & 0.64 & 756 \\
$\mathrm{MZ17}$ & 308 & 3.810 & 3.29 & 0.1675 & 2.57 & 0.78 & 1595 \\
$\mathrm{MZ3}$ & 2965 & 0.783 & 0.90 & 0.0937 & 0.71 & 0.79 & 587 \\
$\mathrm{MZ32}$ & 365225 & 0.638 & 1.07 & 0.0821 & 0.57 & 0.54 & 501 \\
$\mathrm{MZ29}$ & 36150 & 0.617 & 1.43 & 0.0827 & 0.94 & 0.66 & 488 \\
$\mathrm{MZ28}$ & 78488 & 0.623 & 0.83 & 0.0808 & 0.56 & 0.67 & 492 \\
$\mathrm{MZ27}$ & 4760 & 0.651 & 0.92 & 0.0782 & 0.63 & 0.68 & 509 \\
$\mathrm{MZ26}$ & 4869 & 0.642 & 1.16 & 0.0790 & 0.80 & 0.68 & 504 \\
$\mathrm{MZ25}$ & 4059 & 0.625 & 1.16 & 0.0764 & 0.82 & 0.71 & 493 \\
$\mathrm{MZ24}$ & 25051 & 0.569 & 1.47 & 0.0724 & 1.01 & 0.68 & 457 \\
$\mathrm{MZ23}$ & 2008 & 0.645 & 1.61 & 0.0783 & 0.94 & 0.59 & 505 \\
$\mathrm{MZ22}$ & 2732 & 0.561 & 2.09 & 0.0749 & 0.79 & 0.38 & 452 \\
$\mathrm{MZ21}$ & 24094 & 0.600 & 1.25 & 0.0835 & 0.87 & 0.69 & 477 \\
$\mathrm{MZ19}$ & 168798 & 0.632 & 0.90 & 0.0811 & 0.64 & 0.71 & 498 \\
$\mathrm{MZ16}$ & 10229 & 0.613 & 1.27 & 0.0777 & 0.89 & 0.70 & 486 \\
$\mathrm{MZ8}$ & 28341 & 0.694 & 1.41 & 0.0880 & 0.92 & 0.65 & 535 \\
$\mathrm{MZ6}$ & 23456 & 0.696 & 1.42 & 0.0882 & 0.92 & 0.65 & 537 \\
$\mathrm{MZ5}$ & 23831 & 0.685 & 1.29 & 0.0867 & 0.94 & 0.73 & 530 \\
$\mathrm{MZ4}$ & 35301 & 0.704 & 1.22 & 0.0894 & 0.83 & 0.68 & 541 \\
$\mathrm{MZ2}$ & 148937 & 0.706 & 0.95 & 0.0899 & 0.77 & 0.81 & 542 \\
$\mathrm{MZ1}$ & 115607 & 0.716 & 1.18 & 0.0918 & 0.95 & 0.81 & 548 \\
$\mathrm{MZ30}$ & 152456 & 0.650 & 0.91 & 0.0831 & 0.56 & 0.61 & 508 \\
$\mathrm{MZ14}$ & 34481 & 0.656 & 1.10 & 0.0842 & 0.68 & 0.62 & 512 \\
$\mathrm{MZ12}$ & 8306 & 0.660 & 2.17 & 0.0847 & 2.06 & 0.95 & 515 \\
$\mathrm{MZ31}$ & 10983 & 0.675 & 0.97 & 0.0839 & 0.58 & 0.60 & 524 \\
$\mathrm{MZ15}$ & 4670 & 0.665 & 1.44 & 0.0838 & 1.07 & 0.74 & 518 \\
$\mathrm{MZ13}$ & 13640 & 0.659 & 1.15 & 0.0834 & 0.77 & 0.67 & 514 \\
$\mathrm{MZ11}$ & 7526 & 0.668 & 0.87 & 0.0842 & 0.53 & 0.61 & 519 \\
$\mathrm{MZ10}$ & 10574 & 0.663 & 1.02 & 0.0843 & 0.75 & 0.73 & 517 \\
$\mathrm{MZ9}$ & 21056 & 0.673 & 2.06 & 0.0848 & 1.37 & 0.67 & 523 \\
$\mathrm{MZ7}$ & 5412 & 0.678 & 1.31 & 0.0841 & 0.87 & 0.67 & 525 \\
\hline & & & & & & &
\end{tabular}




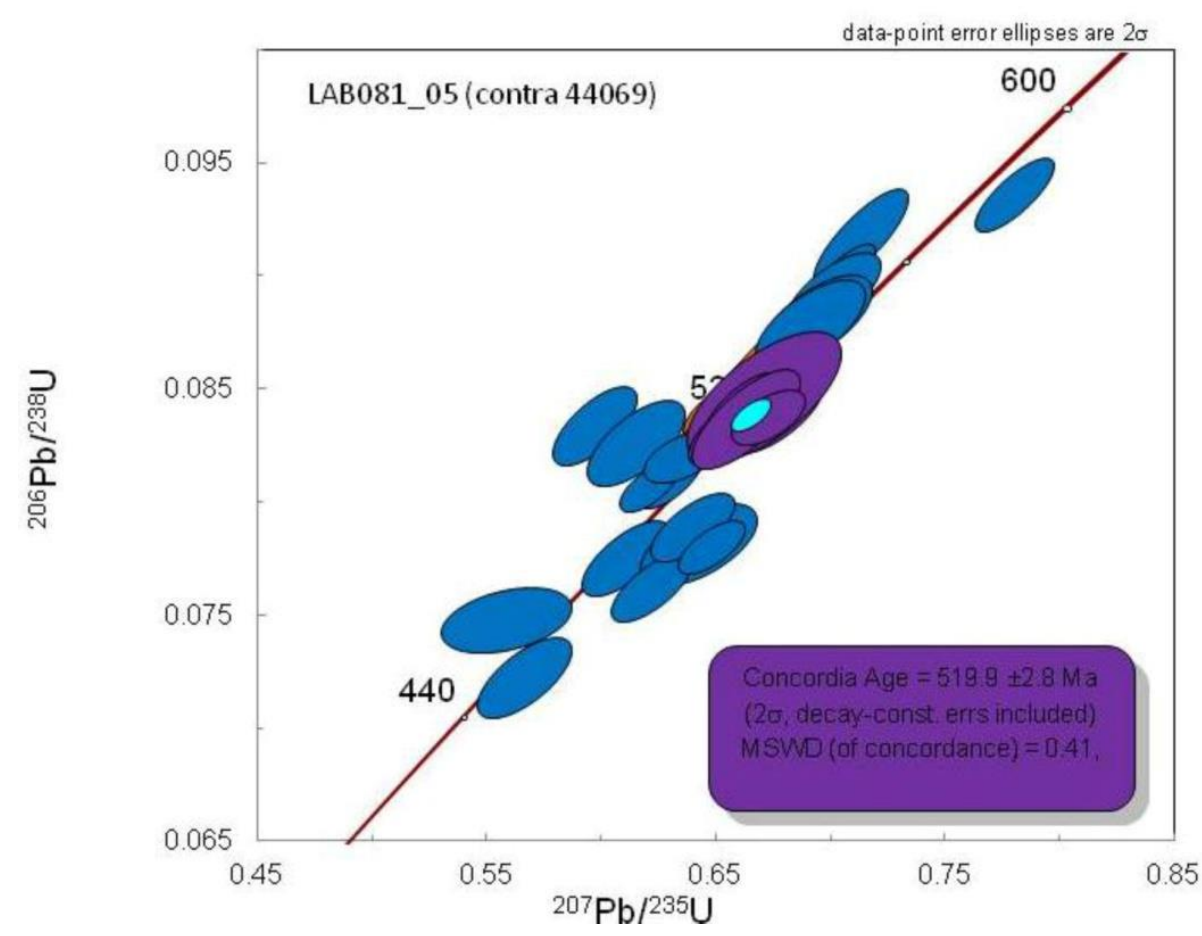

Figure 2. 11: U-Pb Concordia diagram of monazite from the Boanerges pegmatite. The purple ellipses were used to calculate the concordia age.

An alternative method for dating rocks is the analysis of Th- and U-bearing minerals, such as monazite, xenotime and uraninite, using an electron microprobe, a non-destructive, in situ, and high-resolution method. This method was used on $0.05-1$ $\mathrm{mm}$ euhedral to subhedral crystals of uraninite from the São Júlio pegmatite. In this method, it is assumed that all of the $\mathrm{Pb}$ in the sample has a radiogenic origin from the decay of $U$ and Th. Thus, as suggested by Kempe (2003), well-preserved crystals with little or no alteration visible in backscattered images were analyzed.

The $\mathrm{U}$ and $\mathrm{Pb}$ results were used in equation (3) of Bowles (1990) to produce calculated chemical ages between 411 and $560 \mathrm{Ma}$, which correspond to the minimum age interval of uraninite crystallization (table 2.9). The uraninite from the São Júlio pegmatite can be chronologically linked to the 519 Ma Boanerges pegmatite. Considering that the uraninite crystals are included in a phosphate mass and that this mass in some samples was exposed to hydrothermal activity, as confirmed by the phosphate association with Fe and Mn (Queiroz et al. in preparation), it is reasonable to think that a certain amount of $\mathrm{Pb}$ in the uraninite has been lost, yielding ages younger than 500 Ma. Alexandre \& Kyser (2005) described Pb loss and cation substitution in uraninite as a result of late circulation of fluids and their influence on chemical dating. In the histogram of figure 2.12 , half of the calculated ages show results ranging between 
500 and $560 \mathrm{Ma}$, a maximum value that is similar to the accurate results in the isotope analysis available in the literature.

Table 2. 9: U-Pb values and the calculated age by the chemical dating.

\begin{tabular}{|c|c|c|c|}
\hline Sample & $\mathrm{U}(\%)$ & $\mathrm{Pb}(\%)$ & Age (Ma) \\
\hline Urn 1 & 76.70 & 5.00 & 448.0 \\
\hline Urn 2 & 77.22 & 5.84 & 516.9 \\
\hline Urn 3 & 77.45 & 5.90 & 520.9 \\
\hline Urn 4 & 75.78 & 5.76 & 519.1 \\
\hline Urn 5 & 76.74 & 5.75 & 512.1 \\
\hline Urn 6 & 72.66 & 5.82 & 546.3 \\
\hline Urn 7 & 73.87 & 5.08 & 471.5 \\
\hline Urn 8 & 74.14 & 5.42 & 500.4 \\
\hline Urn 9 & 71.36 & 4.77 & 459.1 \\
\hline Urn 10 & 74.55 & 5.47 & 501.9 \\
\hline Urn 11 & 77.20 & 5.12 & 455.9 \\
\hline Urn 12 & 72.77 & 4.73 & 447.2 \\
\hline Urn 13 & 76.23 & 4.74 & 428.3 \\
\hline Urn 14 & 75.86 & 5.51 & 496.8 \\
\hline Urn 15 & 75.72 & 5.12 & 464.5 \\
\hline Urn 16 & 76.10 & 5.67 & 509.7 \\
\hline Urn 17 & 81.93 & 6.51 & 542.1 \\
\hline Urn 18 & 81.90 & 5.71 & 477.7 \\
\hline Urn 19 & 84.21 & 6.53 & 529.6 \\
\hline Urn 20 & 80.31 & 5.66 & 482.9 \\
\hline Urn 21 & 79.65 & 5.04 & 435.1 \\
\hline Urn 22 & 80.84 & 6.21 & 524.7 \\
\hline Urn 23 & 78.84 & 5.76 & 500.4 \\
\hline Urn 24 & 81.07 & 6.41 & 539.4 \\
\hline Urn 25 & 80.22 & 4.92 & 422.1 \\
\hline Urn 26 & 80.48 & 5.95 & 506.1 \\
\hline Urn 27 & 78.42 & 4.68 & 411.5 \\
\hline Urn 28 & 81.89 & 5.32 & 446.9 \\
\hline Urn 29 & 80.96 & 5.87 & 496.4 \\
\hline Urn 30 & 81.44 & 5.46 & 460.3 \\
\hline Urn 31 & 81.13 & 6.12 & 515.6 \\
\hline Urn 32 & 80.88 & 6.37 & 537.4 \\
\hline Urn 33 & 81.59 & 6.05 & 507.0 \\
\hline Urn 34 & 81.51 & 6.13 & 513.8 \\
\hline Urn 35 & 81.08 & 6.20 & 522.5 \\
\hline Urn 36 & 81.27 & 6.26 & 526.0 \\
\hline Urn 37 & 81.42 & 6.19 & 519.6 \\
\hline
\end{tabular}




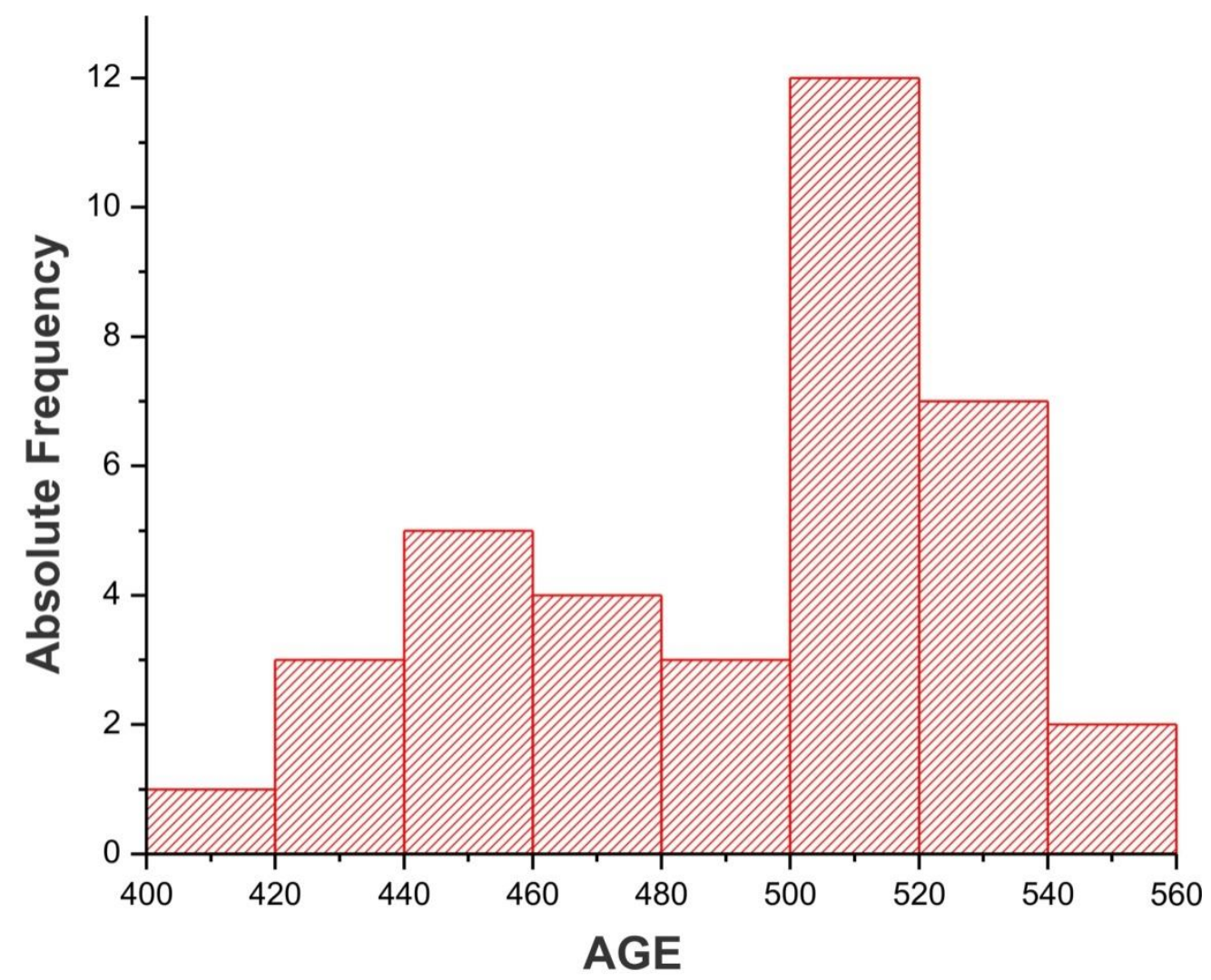

Figure 2. 12: Frequency histogram of the calculated uraninite ages.

\subsection{THE MATA AZUL SUITE AT LEVANTINA QUARRY}

The Mata Azul Suite is poorly described in literature, Lacerda Filho et al. (1999) and Polo \& Diener (2013) refer to this suite as post tectonic granitic intrusions of neoproterozoic age, crosscutting metasedimentary rocks of Serra da Mesa Group and containing several pegmatite dykes. Polo \& Diener (2013) mention in their geological map a U-Pb age of 560Ma in zircon, but no references to sampling area and type of rock are mentioned.

On the development of this work, the type area of this suite, as well as the sampling area, is located in a quarry for ornamental rocks from the Levantina enterprise, next to the Mata Azul district, in the municipality of Montividiu do Norte. The granite crops out as a white leucocratic rock forming a 7-km-long elongated pluton in slightly wavy terrain (figure 2.2). There are a number of complex textures in the mining area of the quarry (figure 2.13), including aplite facies (gray color) of centimetric to metric scale and coarse leucogranite and pegmatite facies with megacrystals of potassic 
feldspar. The mineralogical composition in all the facies is basically the same and differs only slightly in mineral percentage. These rocks contain quartz, bluish-grey potassic feldspar, white plagioclase, perthitic texture zones and to a lesser extent biotite and muscovite (mica up to $10 \%$ ). The plagioclase is usually oligoclase $\left(\mathrm{An}_{11-15}\right)$, and it is the most abundant feldspar in the coarse leucogranites and is present in some portions of the aplites.

The most common accessory mineral is dark red almandine, which is present in the aplitic facies and coarse leucogranite. This mineral sometimes forms nodules with a large amount of millimetric crystals. The second most common accessory mineral is fluorapatite which can also form crystal agglomerates. Zircon, monazite and cassiterite were also identified either in thin sections, as a small number of crystals, or by EDS analysis via the microprobe.
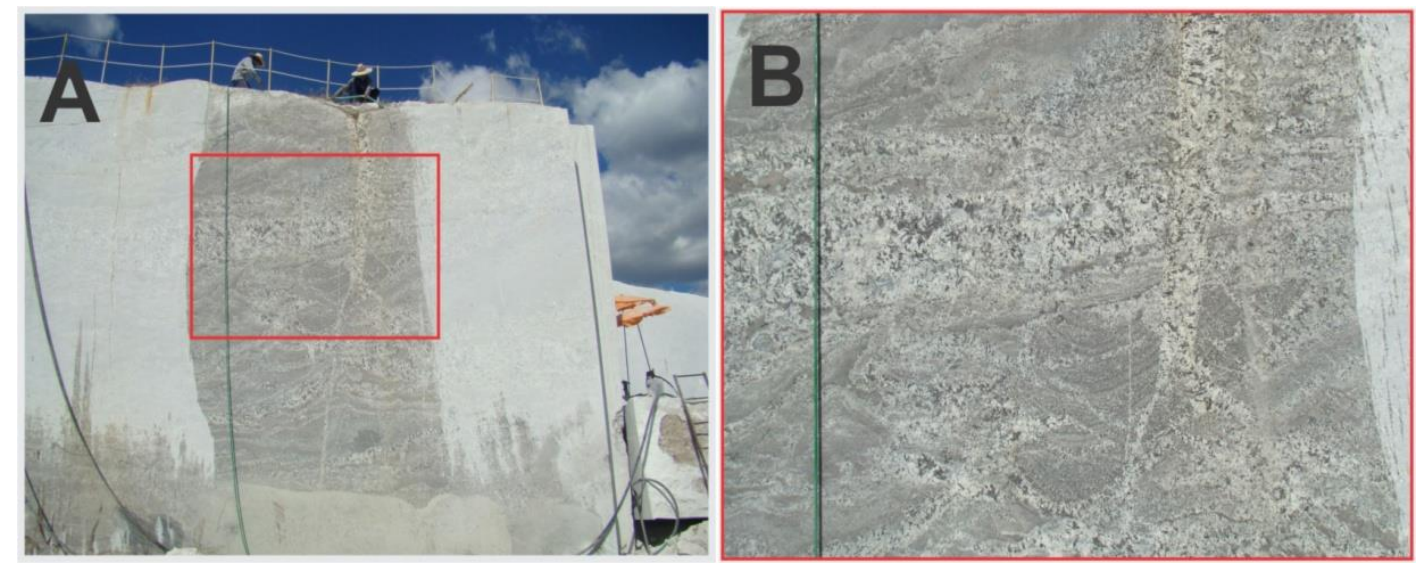

Figure 2. 13: Mata Azul Leucogranite. (A): Mata Azul Suite exposition at Levantina quarry. (B): Detail of red square in " $A$ " showing the complex textures.

\subsubsection{Geochemistry of the Mata Azul Suite leucogranite}

The leucogranite facies from the Levantina quarry (table 2.10) is strongly peraluminous with a $\mathrm{A} / \mathrm{CNK}$ value between 1.05 and 1.35. It contains low contents of $\mathrm{Fe}, \mathrm{Mg}, \mathrm{Ca}$, Ti and $\mathrm{Ba}$ and high contents of $\mathrm{Rb}, \mathrm{Ga}, \mathrm{B}$ and $\mathrm{F}$, a pattern that is very common in extremely fractionated granite bodies, indicating an evolved granite signature.

The chemistry of the granites from the Mata Azul Suite was compared to the chemistry of a variety of granitic rocks related to the geological context of the studied area. This selection includes granites from the Magmatic Arc of Goiás, the Serra 
Dourada Suite and the Aurumina Suite, studied by Botelho et al. (2002 e 2006), Alvarenga et al. (2007), and Araujo Filho et al. 2017.

Table 2. 10: Chemical composition of coarse grain leucogranites associated to Mata Azul Suite and paragneiss.

\begin{tabular}{|c|c|c|c|c|c|c|c|c|}
\hline \multicolumn{9}{|c|}{ Major elements } \\
\hline & \multicolumn{5}{|c|}{ Levantina quarry coarse grain leucogranites } & \multicolumn{2}{|c|}{ "17" barren pegmatite } & Paragneiss \\
\hline & MA1 & MA2 & MA3 & MA4 & MA5 & MA17 & MA22 & RE17 \\
\hline $\mathrm{SiO}_{2}$ & 73.87 & 70.1 & 71.6 & 71.4 & 74.4 & 75 & 74.8 & 68.45 \\
\hline $\mathrm{TiO}_{2}$ & 0.01 & 0.02 & 0.01 & 0.01 & 0.01 & $<0.01$ & 0.01 & 0.64 \\
\hline $\mathrm{Al}_{2} \mathrm{O}_{3}$ & 15.23 & 14.3 & 13.95 & 14.15 & 13.75 & 14.3 & 15.33 & 16.01 \\
\hline $\mathrm{FeO}_{\mathrm{t}}$ & 0.69 & 0.79 & 1.18 & 1.12 & 0.92 & 0.47 & 0.19 & 1.99 \\
\hline $\mathrm{MnO}$ & 0.08 & 0.06 & 0.2 & 0.15 & 0.11 & 0.04 & $<0.01$ & 0.07 \\
\hline $\mathrm{MgO}$ & 0.06 & 0.09 & 0.08 & 0.07 & 0.07 & 0.03 & 0.08 & 2.06 \\
\hline $\mathrm{CaO}$ & 0.56 & 0.35 & 0.56 & 0.68 & 0.68 & 0.49 & 1.92 & 2.55 \\
\hline $\mathrm{Na}_{2} \mathrm{O}$ & 4.05 & 3.05 & 3.91 & 4.33 & 4.47 & 5.2 & 6.48 & 5.94 \\
\hline $\mathrm{K} 2 \mathrm{O}$ & 4.81 & 6.03 & 3.6 & 3.2 & 3.14 & 3.62 & 0.48 & 1.44 \\
\hline $\mathrm{P}_{2} \mathrm{O}_{5}$ & 0.12 & 0.12 & 0.09 & 0.1 & 0.15 & 0.09 & 0.08 & 0.2 \\
\hline \multirow[t]{2}{*}{ P.F } & 0.5 & 0.49 & 0.49 & 0.44 & 0.41 & 0.7 & 0.6 & 0.5 \\
\hline & & & \multicolumn{4}{|c|}{ Trace elements (ppm) } & & \\
\hline $\mathrm{Be}$ & 3 & --- & --- & --- & --- & 6 & 72 & 6 \\
\hline $\mathrm{Rb}$ & 211.2 & --- & --- & --- & --- & 207.8 & 38.9 & 61 \\
\hline $\mathrm{Cs}$ & 1.9 & 1.95 & 1.46 & 1.31 & 1.09 & 2.5 & 0.4 & 1.8 \\
\hline $\mathrm{Ba}$ & 15 & 31.3 & 15.9 & 11.2 & 10 & 32 & 35 & 212 \\
\hline $\mathrm{Sr}$ & 19.3 & 22.6 & 22 & 21.4 & 23.1 & 22.1 & 106.2 & 130.2 \\
\hline $\mathrm{Ga}$ & 21.2 & 19.4 & 18.9 & 20.7 & 18.1 & 24.6 & 26.2 & 14.7 \\
\hline $\mathrm{Sn}$ & 3 & --- & --- & --- & --- & 3 & 3 & 3 \\
\hline $\mathrm{Ta}$ & 0.6 & --- & --- & --- & --- & 1.3 & 3.5 & 0.9 \\
\hline $\mathrm{Nb}$ & 8 & 8.8 & 7.6 & 8.4 & 5.9 & 21.9 & 7.8 & 17.3 \\
\hline $\mathrm{Th}$ & 1.3 & 1.78 & 0.81 & 3.01 & 1.13 & 2.8 & 0.6 & 11.3 \\
\hline $\mathrm{U}$ & 4.7 & --- & --- & --- & --- & 5.7 & 3.2 & 3.3 \\
\hline $\mathrm{Zr}$ & 35.8 & 17 & 7 & 63 & 15 & 20 & 8 & 195.1 \\
\hline Hf & 1.8 & --- & --- & --- & --- & 1.5 & 1 & 4.9 \\
\hline $\mathrm{Y}$ & 10.4 & 7.2 & 12.2 & 20.5 & 7.8 & 10.8 & 8 & 23.7 \\
\hline $\mathrm{Zn}$ & 3 & --- & --- & --- & --- & 8 & 22 & 72 \\
\hline B & 7 & --- & --- & --- & --- & 6 & 3 & \\
\hline $\mathrm{F}$ & 263 & --- & --- & --- & --- & 216 & 263 & \\
\hline \multirow[t]{2}{*}{$\mathrm{Li}$} & 31 & & & & & 40 & 35 & \\
\hline & & & \multicolumn{4}{|c|}{ REE (ppm) } & & \\
\hline $\mathrm{La}$ & 2 & 2.6 & 1.4 & 4.4 & 2.1 & 2.9 & 3.2 & 35.1 \\
\hline $\mathrm{Ce}$ & 4.8 & 5.2 & 2.5 & 9.1 & 4 & 6.5 & 7.3 & 84.1 \\
\hline $\operatorname{Pr}$ & 0.59 & 0.62 & 0.31 & 1.17 & 0.47 & 0.72 & 0.89 & 8.58 \\
\hline $\mathrm{Nd}$ & 2.5 & 2.2 & 1 & 4.1 & 1.6 & 2.3 & 3.3 & 34.1 \\
\hline $\mathrm{Sm}$ & 0.8 & 0.86 & 0.48 & 1.52 & 0.61 & 0.85 & 1.35 & 7.05 \\
\hline $\mathrm{Eu}$ & 0.06 & 0.08 & 0.09 & 0.08 & 0.08 & 0.09 & 0.48 & 1.41 \\
\hline $\mathrm{Gd}$ & 0.83 & 0.79 & 0.67 & 1.92 & 0.61 & 1.03 & 1.43 & 5.65 \\
\hline $\mathrm{Tb}$ & 0.26 & 0.18 & 0.24 & 0.49 & 0.17 & 0.29 & 0.3 & 0.87 \\
\hline Dy & 1.4 & 1.21 & 1.91 & 3.37 & 1.3 & 1.65 & 1.68 & 5.37 \\
\hline Ho & 0.31 & 0.25 & 0.36 & 0.67 & 0.28 & 0.26 & 0.28 & 0.99 \\
\hline $\mathrm{Er}$ & 1.06 & 0.81 & 1.21 & 2.06 & 0.87 & 0.98 & 0.66 & 2.85 \\
\hline $\mathrm{Tm}$ & 0.2 & 0.15 & 0.26 & 0.39 & 0.18 & 0.14 & 0.13 & 0.41 \\
\hline $\mathrm{Yb}$ & 1.74 & 1.1 & 2.18 & 2.9 & 1.38 & 1.13 & 0.79 & 2.8 \\
\hline $\mathrm{Lu}$ & 0.22 & 0.16 & 0.29 & 0.43 & 0.19 & 0.14 & 0.1 & 0.4 \\
\hline
\end{tabular}


The aim of this comparison is to demonstrate the resemblance between the granites from the Mata Azul Suite (including the previously described "17" barren pegmatite) and a typical fractionated granitic source of pegmatites.

The granites from the Mata Azul Suite, Aurumina Suite and Goiás Magmatic Arc plot in the field of syn-collisional granites (syn-COLG) in the Ta vs. Yb diagram of Pearce et al. (1984), as expected for the parental granites of pegmatites in the LCT family. The Serra Dourada granites are clearly related to an intraplate environment, as highlighted by previous works (Marini \& Botelho, 1986; Botelho 1992).

The concentration of rare earth elements (REEs) in LCT granites is low, in most cases not more than twenty times the chondrite values (Černý, 1991). LCT granites have sub-horizontal or kinked REE patterns. The latter involves a steep decrease from La to $\mathrm{Sm}$ and a flatter pattern from $\mathrm{Gd}$ to $\mathrm{Lu}$, indicating depletion in heavy rare earth elements (HREEs). Both patterns feature strong negative $\mathrm{Eu}$ anomalies. Among the samples considered in this study, it is the Mata Azul Suite that displays REE patterns similar to the model of an LCT evolved granite depleted in REEs (figure 2.15). The coarse grain leucogranites of the Mata Azul Suite exhibit a sub-horizontal pattern with strong negative Eu anomalies and REE values less than twenty times the chondrite values. The exception is the sample "MA22" from the previously described dyke that is rich in Naplagioclase and with some contamination characteristics. This rock shows features of a digestion process (figure 2.6), which likely increased the concentration of specific elements, such as $\mathrm{Mg}, \mathrm{Ca}, \mathrm{Sr}$ and $\mathrm{Ga}$, in comparison with the intrusive rock sample "MA17", for example, which occurs in the same context. The plagioclase concentration explains the weak positive $\mathrm{Eu}$ anomaly and the contamination caused the decrease in HREEs and the REE fractionation similar to that of the paragneiss (figure 2.15).

The REE patterns of the studied Mata Azul samples are similar to the pattern of a pegmatitic granite with the same petrographic and chemical characteristics described by Marini et al. (1992). 

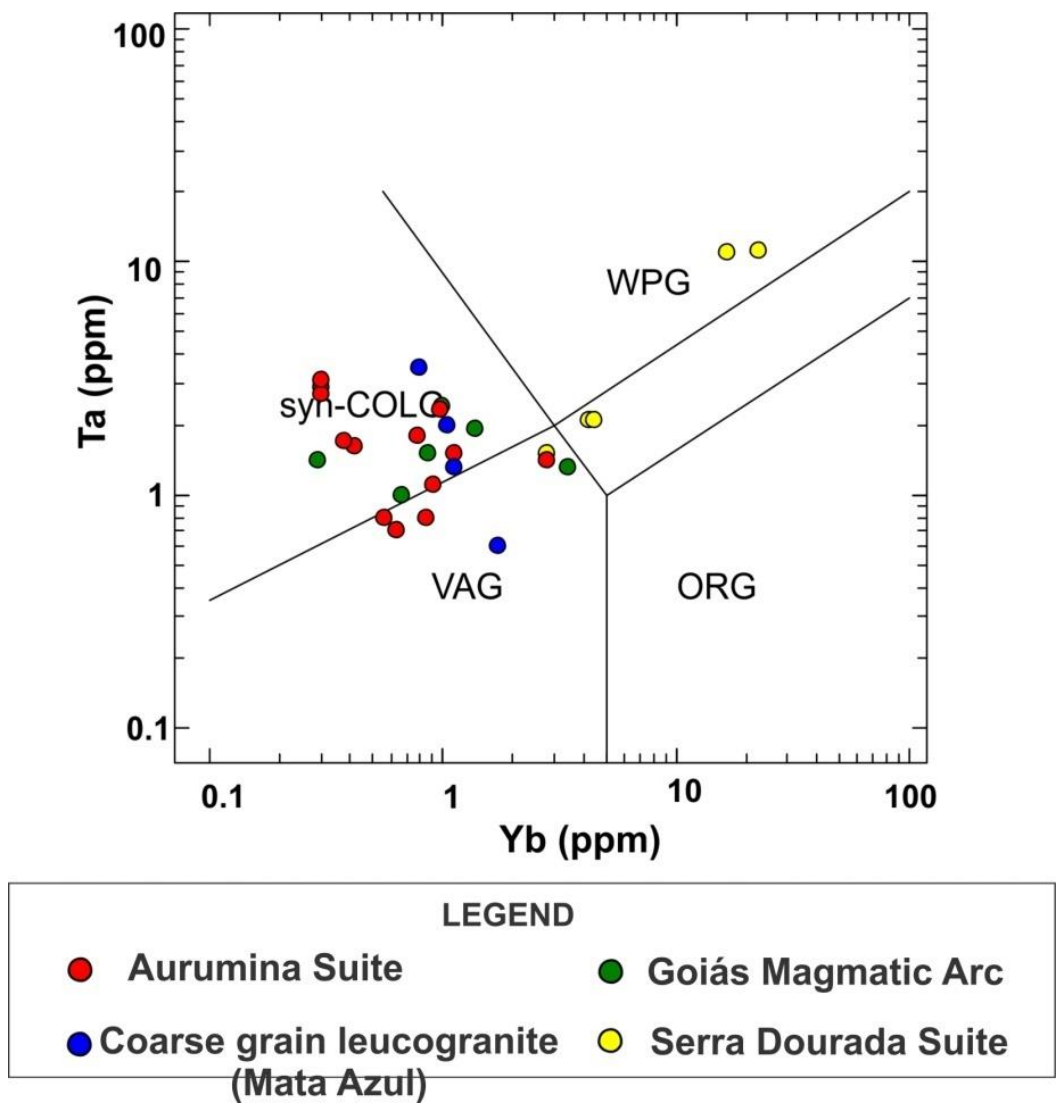

Figure 2. 14: Mata Azul leucogranite compared to regional granitic rocks in the tectonic setting diagram of Pearce et al. 1984.
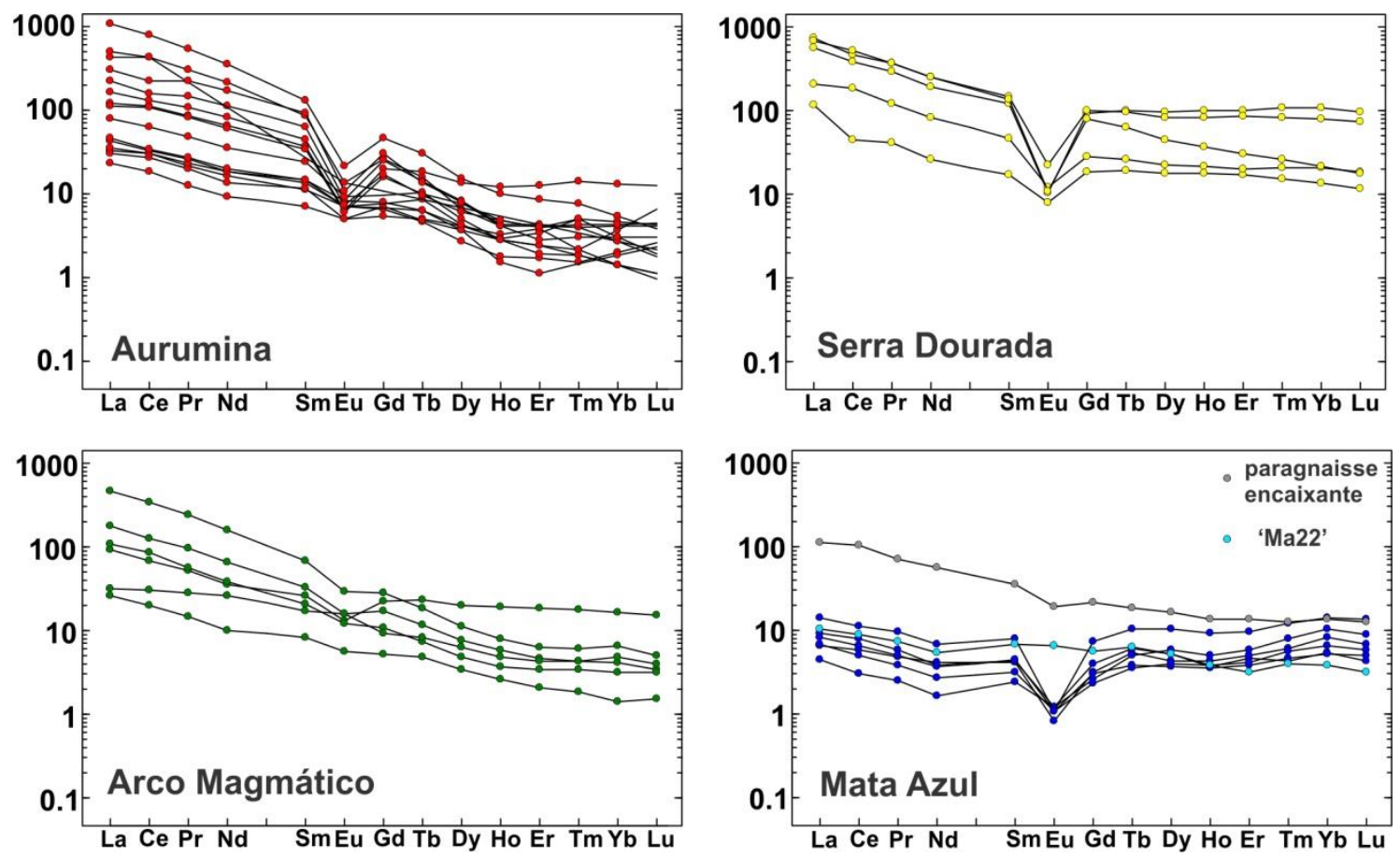

Figure 2. 15: Chondrite-normalized REE patterns for different granitic suites in the studied area. In the Mata Azul Suite diagram are included the sample "MA22" and the paragneiss country rock. Chondrite of Boynton (1984). 


\subsection{DISCUSSION AND THE MATA AZUL PEGMATITIC FIELD}

The frequent presence of Li-minerals (lepidolite trilithionite, elbaite, spodumene) and scarcity of Y-and REE minerals in the pegmatites described in the previous sections indicate that they belong to the LCT family (Černý 1990 and 1991; Martin \& DeVito 2005). According to the classification of Černý \& Ercit (2005), the pegmatites explored for beryl belong to the beryl type and the pegmatites explored for tourmaline belong to the complex type. Most of the pegmatites can be classified in subtypes: the Pichorra, São Júlio and Fazenda Mesquita pegmatites are considered to belong to the berylcolumbite-phosphate subtype, and all of the pegmatites explored for tourmaline, with the exception of the Berilão, belong to the elbaite subtype.

Many evidences corroborate the idea that the Mata Azul Suite is the source of the studied pegmatites. Suites in or close to the studied area include: The Mata Azul Suite, the Serra do Encosto and Serra Dourada A-type granites, Peixe Alcaline Suite, Rio das Almas Suite and the S-type Aurumina Suite. The Peixe Alcaline Suite and the A-type granites are anorogenic, as described in literature; the pegmatite associated to this granite source is related to NYF family which is evident in its mineralogy and geochemistry. In Peixe Suite, zircon, allanite and monazite bearing pegmatites show a plenty of REE minerals characteristic to NYF family and absent as important phases in the studied pegmatites. The poorly studied Rio das Almas Suite is mention as related to the Serra Dourada and Serra do Encosto anorogenic granites by Araújo Filho et al. (2017).

The syn- to post-orogenic tectonic setting is the most favorable for the occurrence of LCT granite and pegmatites in collision belts, where the granites have an S-type and peraluminous signature influenced by metasedimentary sources (Martin \& DeVitto 2005). Both, Mata Azul and Aurumina Suites have these signatures, and pegmatitic bodies are related to the Aurumina Suite in NE of Goiás state. Nevertheless, the Aurumina granites and pegmatites have paleoproterozoic ages, between 2.0 and $2.2 \mathrm{Ga}$ (Botelho et al. 2006), compared with the neoproterozoic age of Boanerges and São Júlio pegmatites.

Ultimately, the complex variation in texture presented by the Mata Azul Suite at Levantina quarry is very similar to many descriptions of granite sources of pegmatites 
around the world (Černý 1982 and 1991, Martin \& DeVitto 2005, Beurlen et al. 2009, Wise \& Brown 2010).

The occurrence of evolved granites, simple pegmatites and mineralized pegmatites suggest the existence of a granite-pegmatite system in the area of study. In the models proposed by Trueman \& Černý (1982), Černý (1991) and London (2008), the regional evolution of granitic-pegmatitic bodies can be observed at different scales, ideally starting from the roof of a parental pluton, from where many pegmatitic bodies are ejected and mainly follow a vertical trend. The chemical fractionation produces zoning in relation to the granite source, in which the differentiation becomes stronger in the more distant bodies. The chemical fractionation is invariably reflected in the mineralogy of each pegmatite, and those closest to the parental granite bodies have simple mineralogy, sometimes containing only quartz, feldspar and micas. In contrast, the farthest bodies show a higher volume of minerals containing volatile elements and/or rare metals. In the figure 2.16 a simplified and "compressed" model shows the relation between many facies of parental granite and pegmatites. In fact, many groups of pegmatites are ejected, probably, from different bodies of source granite, not only one, as showed in the figure.

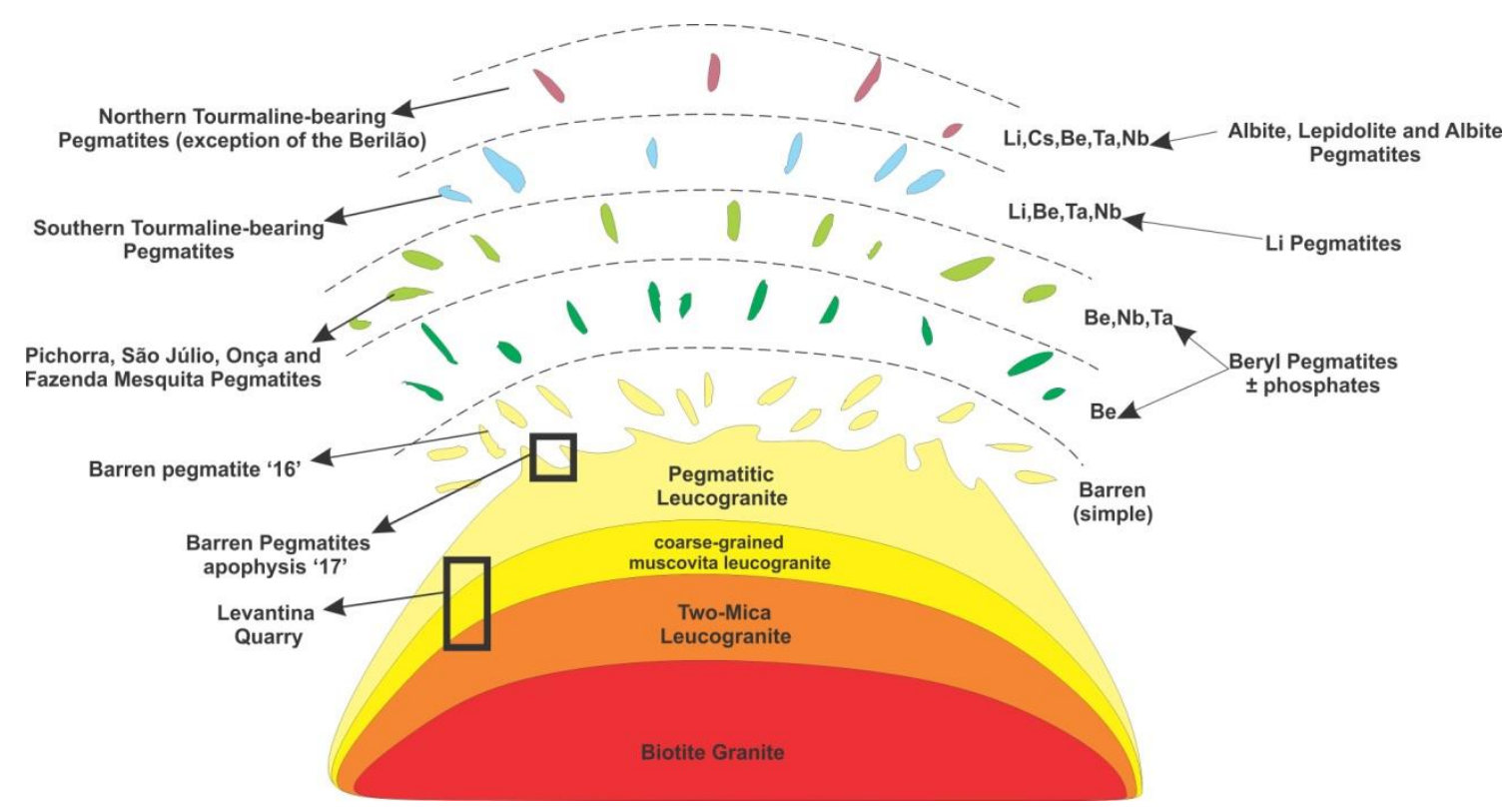

Figure 2. 16: Schematic representation of regional zoning and evolution from a simple biotite granite to a complex pegmatite, applied to the studied pegmatites. Modified from Trueman \& Černý (1982) and London (2008). 
The coarse grain leucogranite from the Mata Azul Suite, sampled in the Levantina quarry, contains three of the four facies related to the ideal parental rock: two-mica leucogranite, coarse muscovite leucogranite and pegmatitic leucogranite (figure 2.16). The top of the granite source has pegmatitic apophyses that can be correlated to the minor intrusions previously described. If it is assumed that fractionation occurred in the parental granite, intrusions such as "MA17" are pegmatitic ejections connected to the source that can be extremely fractionated, producing sodic dykes such as the one represented by the sample MA22 (figure 2.17).

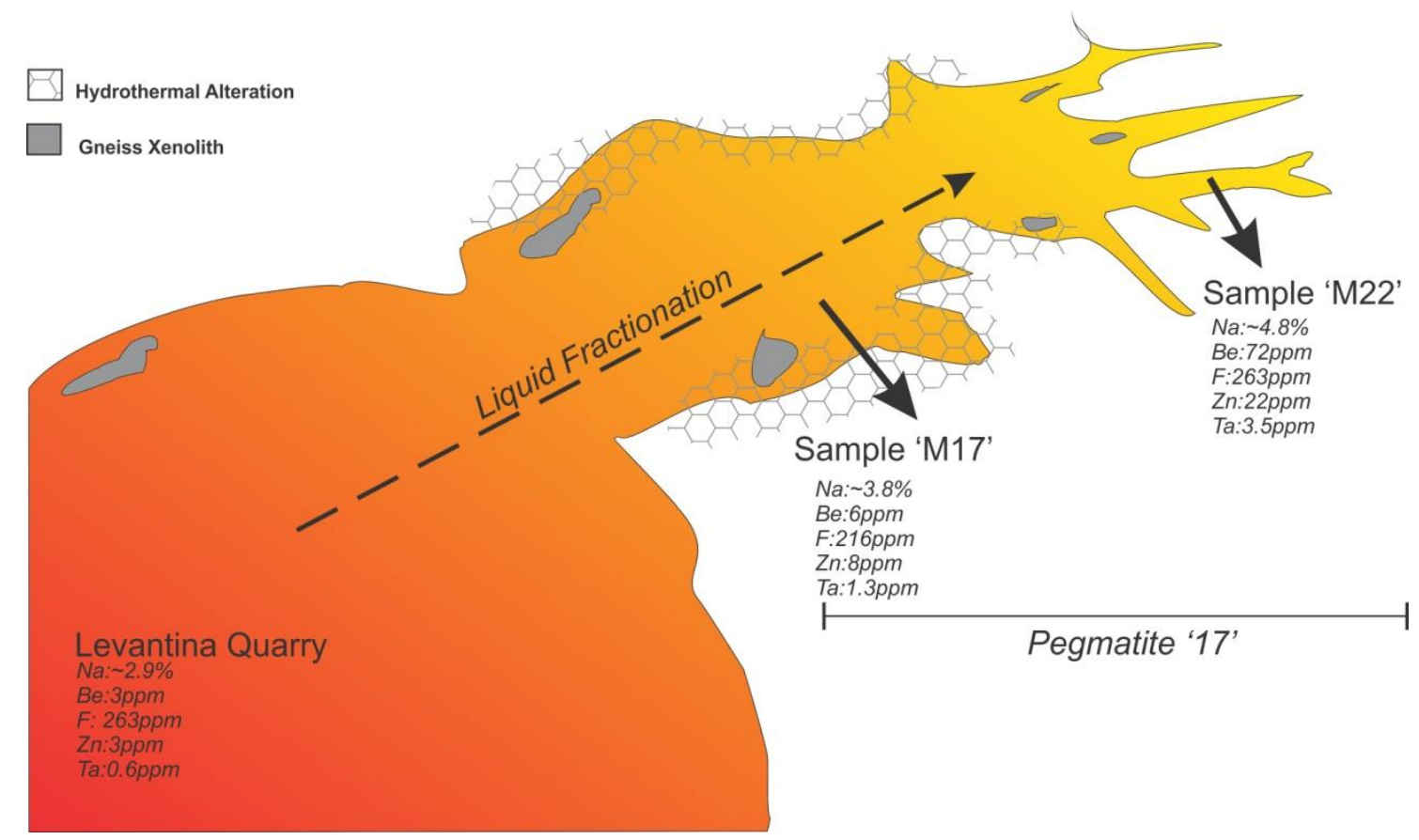

Figure 2. 17: Schematic representation showing the roof of a leucogranitic intrusion of the Mata Azul Suite represented by the Levantina quarry and pegmatitic apophysis of the "17" barren pegmatite (samples M17 and M22) with the chemical variation of some elements. The dashed arrow indicates the evolution of the magma.

Barren pegmatites ejected from the granite source form the first halo of dispersion (figure 2.16), as exemplified in the Novo Horizonte district, where the pegmatite "16" (figure 2.2), which is mostly homogeneous, displays a typical texture of a pegmatite body with ordinary mineralogy: quartz, microcline, biotite, muscovite and almandine.

The chemical composition of the garnet crystals is one of the main tools to differentiate the degree of evolution among barren and mineralized. Černý \& Hawthorne (1982), Baldwin \& Knorring (1983), Whitworth \& Feely (1994), and Lima et al. (2009) proved that the $\mathrm{Mn} / \mathrm{Fe}$ ratio in garnet increases with the fractionation of a granitic body towards the pegmatites. Therefore, it is expected that the garnet from 
more evolved bodies would be richer in spessartine than the garnet from less evolved bodies and from the granite source.

The chemical compositions of the garnet from the Mata Azul leucogranite, the barren pegmatites "17" and " 16 " and the mineralized pegmatites Onça and Boanerges are shown in table 2.11. The crystals of garnet in pegmatites were collected in the preserved or altered wall zone of these bodies. The values of the $\mathrm{Mn} /(\mathrm{Mn}+\mathrm{Fe})$ ratio and the proportion of spessartine clearly increase toward the most differentiated bodies and exhibit a negative correlation with Fe and $\mathrm{Mn}$ in figure 2.18.

Table 2. 11: Representative composition of garnet crystals.

\begin{tabular}{|c|c|c|c|c|c|}
\hline & $\begin{array}{l}\text { Mata Azul } \\
\text { Suite }\end{array}$ & $\begin{array}{l}\text { "17" Barren } \\
\text { Pegmatite }\end{array}$ & $\begin{array}{l}\text { "16" Barren } \\
\text { Pegmatite }\end{array}$ & $\begin{array}{c}\text { Onça pegmatite } \\
\text { (beryl) }\end{array}$ & $\begin{array}{c}\text { Boanerges } \\
\text { pegmatite } \\
\text { (tourmaline) }\end{array}$ \\
\hline & Almandine & Almandine & Almandine & Almandine & Spessartine \\
\hline $\mathrm{SiO}_{2}$ & 35.00 & 34.99 & 34.99 & 35.00 & 37.62 \\
\hline $\mathrm{TiO}_{2}$ & 0.00 & 0.15 & 0.08 & 0.06 & 0.02 \\
\hline $\mathrm{Al}_{2} \mathrm{O}_{3}$ & 21.00 & 20.61 & 20.68 & 23.00 & 19.95 \\
\hline $\mathrm{FeO}_{\text {total }}$ & 35.17 & 34.41 & 32.42 & 28.45 & 15.01 \\
\hline $\mathrm{MnO}$ & 6.26 & 8.27 & 11.17 & 13.18 & 27.57 \\
\hline $\mathrm{MgO}$ & 1.23 & 0.43 & 0.15 & 0.80 & 0.04 \\
\hline $\mathrm{CaO}$ & 0.39 & 0.53 & 0.22 & 0.25 & 0.52 \\
\hline \multirow[t]{2}{*}{ Total } & 99.05 & 99.38 & 99.71 & 100.74 & 100.73 \\
\hline & & \multicolumn{2}{|c|}{ Formula content } & & \\
\hline $\mathrm{Si}$ & 2.912 & 2.919 & 2.918 & 2.838 & 3.068 \\
\hline $\mathrm{Ti}$ & 0.000 & 0.010 & 0.005 & 0.003 & 0.001 \\
\hline $\mathrm{Al}$ & 2.061 & 2.029 & 2.035 & 2.211 & 1.919 \\
\hline $\mathrm{Fe}$ & 2.448 & 2.401 & 2.261 & 1.997 & 1.023 \\
\hline $\mathrm{Mn}$ & 0.441 & 0.584 & 0.789 & 0.905 & 1.905 \\
\hline $\mathrm{Mg}$ & 0.152 & 0.054 & 0.019 & 0.097 & 0.005 \\
\hline $\mathrm{Ca}$ & 0.034 & 0.047 & 0.019 & 0.021 & 0.045 \\
\hline \multirow[t]{2}{*}{$\mathrm{Mn} /(\mathrm{Mn}+\mathrm{Fe})$} & 0.15 & 0.20 & 0.26 & 0.31 & 0.65 \\
\hline & & \multicolumn{2}{|c|}{ Final member composition } & & \\
\hline$\%$ almandine & 78.44 & 76.52 & 71.66 & 63.95 & 32.41 \\
\hline$\%$ spessartine & 15.14 & 20.02 & 27.04 & 31.90 & 65.85 \\
\hline \% pyrope & 5.23 & 1.84 & 0.64 & 3.40 & 0.17 \\
\hline$\%$ grossular & 0.00 & 0.00 & 0.00 & 0.75 & 1.03 \\
\hline
\end{tabular}




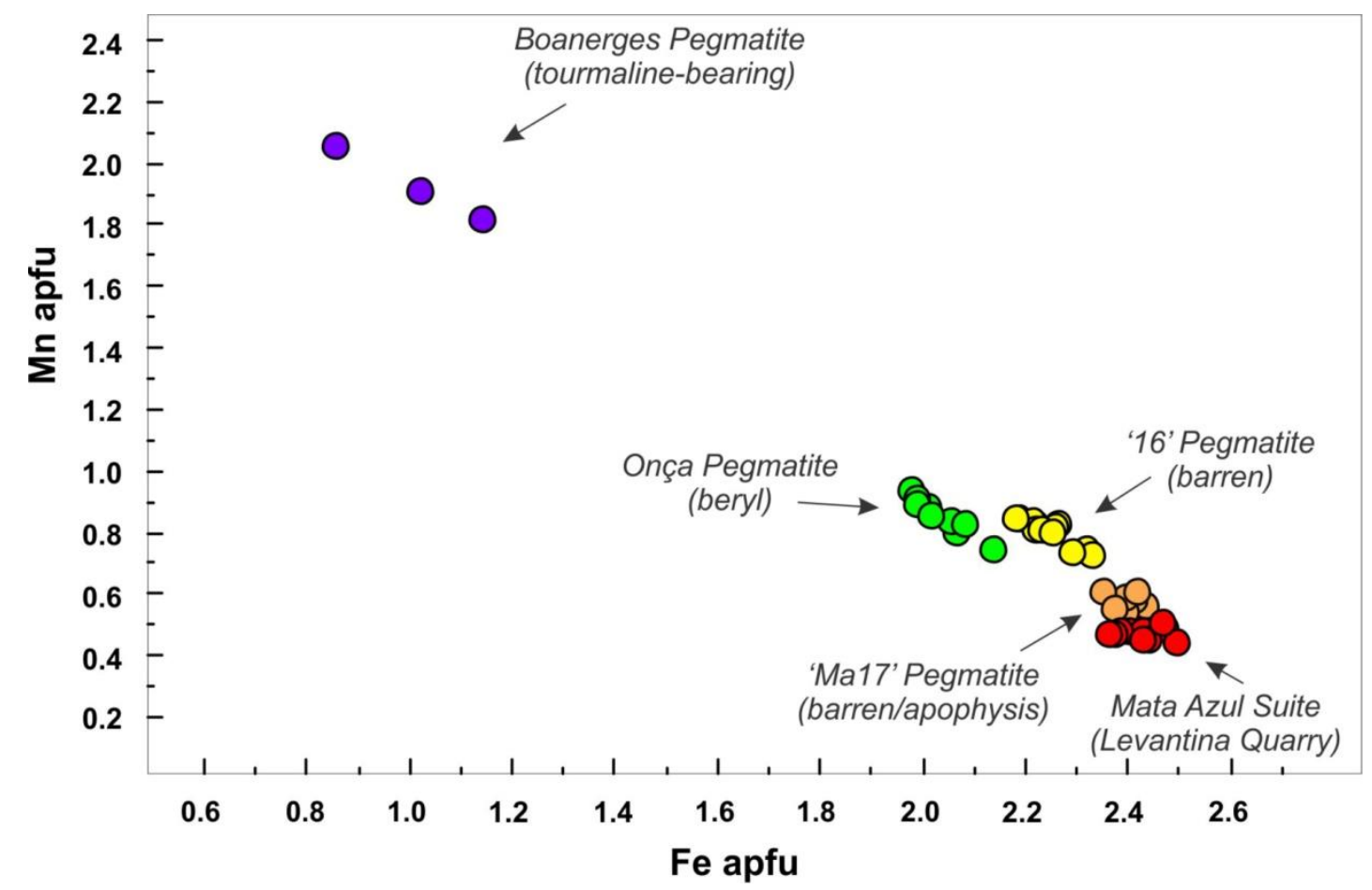

Figure 2. 18: Chemical composition of garnet crystals from the parental Mata Azul leucogranite and the associated pegmatites, showing a negative correlation between Fe and Mn.

The degree of differentiation between the least and the most evolved mineralized pegmatite is clearly indicated by their mineralogy. This comparison can be conducted using minerals that are present in both groups, such as beryl. Figure 2.16 shows an ideal scheme where beryllium is the first rare metal element to saturate and therefore to be incorporated by a mineral phase (beryl). The beryllium affinity to plagioclase (London \& Evensen 2002) and the lack of this mineral in the early pegmatites suggest beryl formed in the highly evolved pegmatites. In this pegmatite group, beryl has blue-green and sometimes yellow colors that correspond to the aquamarine and heliodor varieties. The chemical composition of beryl and consequently its color change during the fractionation of pegmatite bodies. Cornejo \& Bartorelli (2010) state that in pegmatite fields from Minas Gerais, aquamarine and heliodor gems are not found together with goshenite (colorless beryl) and morganite (pink beryl). Černý (1975 and 2002) stated that this beryl evolution is related to a decrease in $\mathrm{Fe}$ and an increase in alkalis due to the evolution of pegmatitic bodies.

Beryl crystals from pegmatites explored for beryl and tourmaline were analyzed, and representative data are shown in table 2.12. In the first group of pegmatites, beryl has mainly green and blue colors and less commonly some shades of yellow. According to the artisanal miners (garimpeiros), aquamarine and heliodor were collected from this type of pegmatite. In the pegmatites explored for tourmaline, beryl crystals are mostly 
white, translucent and sometimes transparent with shades of very light green or pink. Bicolor fragments (pink and green) were rarely collected; they always presented a faded color with rare pink beryl crystals (morganite) of a stronger color. The total $\mathrm{FeO}$ content in beryl from the first group reached $0.73 \%$, while in the second group the highest content was $0.36 \%$. The maximum alkali content in beryl from the first group is $0.56 \%$, while in the second group the alkali content reaches $1.64 \%$ in a pink crystal. Thus, the beryl type can be used to characterize the degree of chemical evolution of the two main types of mineralized pegmatites.

Table 2. 12: Representative composition of beryl crystals from pegmatites explored for beryl and for tourmaline.

\begin{tabular}{|c|c|c|c|c|c|c|c|}
\hline & \multicolumn{2}{|c|}{ São Júlio Pegmatite } & \multicolumn{5}{|c|}{ Boanerges and Marimbondo Pegmatites } \\
\hline & blue & green & White 1 & White 2 & White 3 & White 4 & Pinkish \\
\hline $\mathrm{SiO}_{2}$ & 65.45 & 65.44 & 64.42 & 64.01 & 64.19 & 65.09 & 64.93 \\
\hline $\mathrm{Al}_{2} \mathrm{O}_{3}$ & 18.5 & 18.38 & 18.83 & 19.87 & 20.01 & 18.61 & 18.74 \\
\hline $\mathrm{FeO}_{\text {total }}$ & 0.73 & 0.68 & 0.26 & 0.17 & 0.36 & 0.27 & 0.03 \\
\hline $\mathrm{MnO}$ & 0.03 & 0 & 0.03 & 0.02 & 0.01 & 0.04 & 0 \\
\hline $\mathrm{Na}_{2} \mathrm{O}$ & 0.3 & 0.38 & 0.89 & 0.93 & 0.72 & 0.82 & 1.21 \\
\hline $\mathrm{K}_{2} \mathrm{O}$ & 0.03 & 0.03 & 0.04 & 0.02 & 0.04 & 0.03 & 0.04 \\
\hline $\mathrm{Rb}_{2} \mathrm{O}$ & 0.05 & 0.04 & 0.07 & 0.00 & 0.04 & 0 & 0 \\
\hline $\mathrm{Cs}_{2} \mathrm{O}$ & 0.05 & 0.11 & 0.13 & 0.17 & 0.2 & 0.11 & 0.39 \\
\hline \multirow[t]{2}{*}{ Total } & 85.14 & 85.06 & 84.67 & 85.19 & 85.57 & 84.97 & 85.34 \\
\hline & & & \multicolumn{2}{|c|}{ Formula contents } & & & \\
\hline $\mathrm{Si}$ & 5.965 & 5.972 & 5.917 & 5.845 & 5.841 & 5.947 & 5.928 \\
\hline $\mathrm{Al}$ & 1.987 & 1.977 & 2.038 & 2.138 & 2.146 & 2.004 & 2.016 \\
\hline $\mathrm{Fe}$ & 0.056 & 0.052 & 0.020 & 0.013 & 0.027 & 0.021 & 0.002 \\
\hline $\mathrm{Mn}$ & 0.002 & 0.000 & 0.002 & 0.002 & 0.001 & 0.003 & 0.000 \\
\hline $\mathrm{Na}$ & 0.053 & 0.067 & 0.158 & 0.165 & 0.127 & 0.145 & 0.214 \\
\hline $\mathrm{K}$ & 0.001 & 0.001 & 0.001 & 0.001 & 0.001 & 0.001 & 0.001 \\
\hline $\mathrm{Rb}$ & 0.001 & 0.001 & 0.001 & 0.000 & 0.001 & 0.000 & 0.000 \\
\hline Cs & 0.000 & 0.001 & 0.001 & 0.002 & 0.002 & 0.001 & 0.004 \\
\hline $\mathrm{Be}^{*}$ & 3 & 3 & 3 & 3 & 3 & 3 & 3 \\
\hline
\end{tabular}

The abundant presence of albite and Li-rich minerals, such as elbaite and trilithionite, is also evidence of the higher degree of chemical fractionation of the tourmaline-bearing pegmatites. Moreover the subdivision of the tourmaline-bearing pegmatites into two groups, i.e., the northern and southern groups, indicates not only their location but also their degree of evolution. The northern group, with the exception of the Berilão pegmatite, is more evolved than the southern group due to the presence of a) trilithionite mica and the rare occurrence of spodumene $\left(\mathrm{LiAlSi}_{2} \mathrm{O}_{6}\right)$; b) uncommon elbaites, especially the pink type with low values of Fe and high values of $\mathrm{Li}$ and $\mathrm{Al}$, and c) albite mass with a singular mineral association. 
According to Černý (1991), a pegmatitic field is a terrane occupied by pegmatite groups within a common geological and structural environment, usually smaller than $10,000 \mathrm{~km}^{2}$. The pegmatites were generated during a single tectonomagmatic stage of the regional evolution; they have the same granitic source and approximately the same age. The pegmatite bodies were not generated from a unique intrusion, but they evolved from different bodies of a single suite. In this study based on petrographic, geochemical and geochronological data, the Mata Azul Suite was established as the probable source for the granitic pegmatites, which are probably related to the evolution of the leucogranites.

The approximately $2000-\mathrm{km}^{2}$ study area is located in the border region of Goiás and Tocantins states (figure 2.19). However, because there are pegmatite bodies and Mata Azul intrusions that were not included in this study, the pegmatite-bearing area could be extended further. Thus, the region regarded as the Mata Azul Pegmatitic Field could be larger, especially to the northeast of the Berilão pegmatite, where artisanal miners have reported a number of pegmatite occurrences in the direction of the Retiro district in the region of São Salvador do Tocantins.

The location of the Mata Azul granitic intrusions may be useful as a prospecting guide for pegmatites that have proven profitable for gemstones exploration, especially aquamarine and tourmaline. 


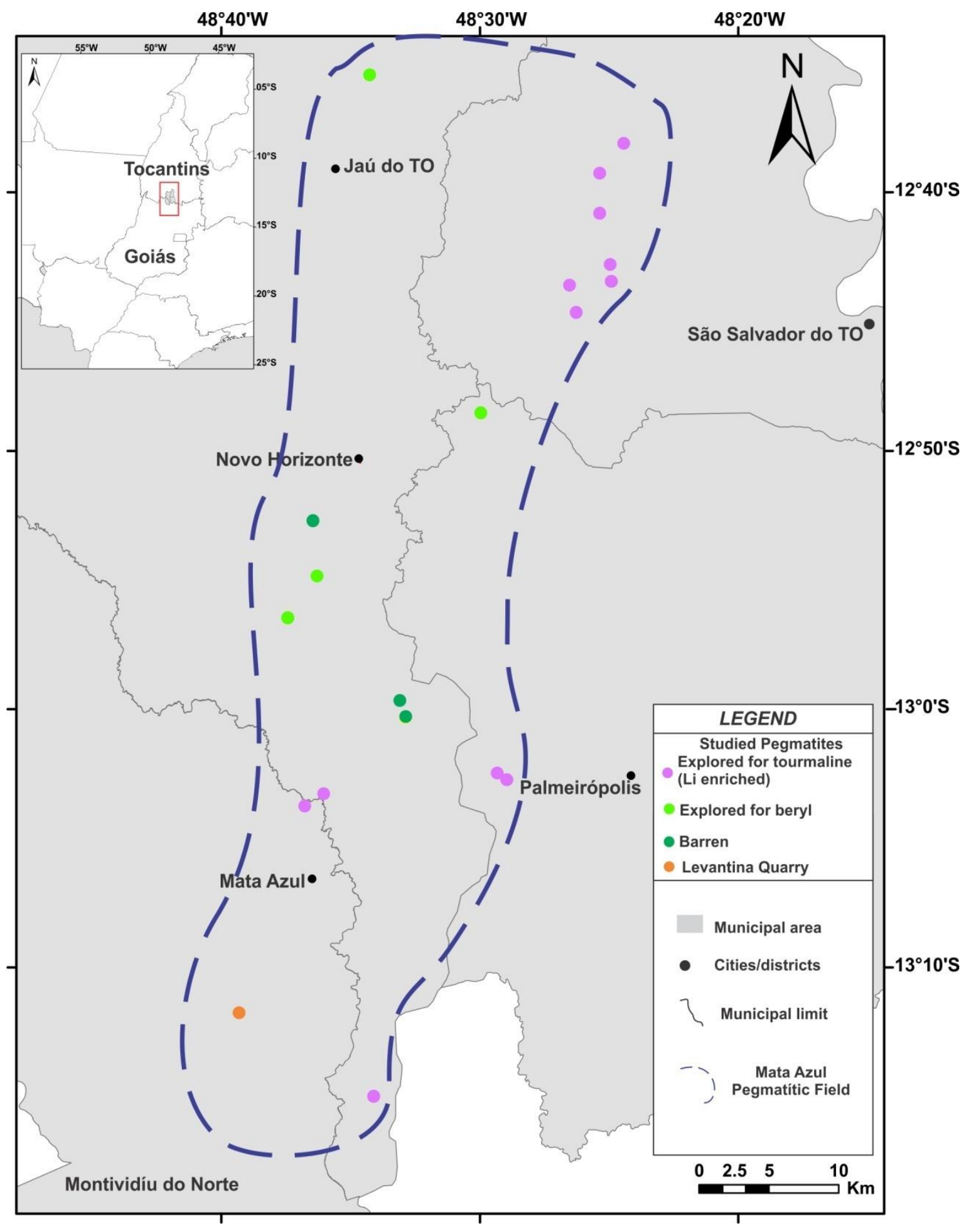

Figure 2. 19: Current área of the Mata Azul Pegmatitic Field in blue. 
Capítulo enviado como artigo para a revista de geociências das USP FOSFATOS DE Fe-Mn PRIMÁRIOS E SECUNDÁRIOS EM PEGMATITOS GRANÍTICOS DO CAMPO PEGMATÍTICO MATA AZUL, REGIÃO CENTRAL DO BRASIL 


\section{CAPÍTULO 3 - Fosfatos de Fe-Mn primários e secundários em pegmatitos graníticos do campo pegmatítico Mata Azul, região central do Brasil}

\section{RESUMO}

No sul do estado do Tocantins e norte do estado de Goiás pegmatitos graníticos estéreis e mineralizados são conhecidos e explorados há muito tempo, mas só recentemente foram caracterizados quanto aos aspectos mineralógicos, composicionais e genéticos e agrupados sob a denominação de Campo Pegmatítico Mata Azul. Em três destes corpos, com mineralização de berilo, fosfatos de Fe e Mn ocorrem sob a forma de nódulos ou massas centimétricas. Duas associações de fosfatos são diferenciadas; na primeira delas, hospedada nos pegmatitos São Júlio e Pichorra, foram descritas três fases primárias, identificadas como zweiselita, sarcopsídeo e F-apatita. Processos hidrotermais alteram estas fases, formando rockbridgeíta, uma fase do subgrupo da alluaudita e heterosita. Na segunda associação, presente no pegmatito Fazenda Mesquita, não há sinal de fosfato primário e todas as fases presentes são secundárias. Rockbridgeíta, de cor verde a alaranjada, compõe boa parte do volume das amostras. Fosfosiderita e strengita aparecem como alterações da rockbridgeíta, às vezes preenchendo cavidades nas massas de fosfato. Nas duas associações, óxidos e hidróxidos de $\mathrm{Fe}$ e $\mathrm{Mn}$, oriundos da oxidação intempérica, correspondem às últimas fases formadas, podendo constituir crostas que recobrem boa parte dos nódulos e massas de fosfatos. Em algumas amostras das associações de fosfatos, cristais de uraninita, gahnita, almandina e Fe-columbita foram identificados.

Palavras chave: Fosfatos de Fe-Mn; Pegmatitos; Mata Azul 


\begin{abstract}
In central Brazil, in the southern Tocantins and in the northern Goiás states, barren and mineralized granitic pegmatites are known and explored for a long time, but only in recent years they were properly characterized and grouped in the so called Mata Azul Pegmatitic Field. In three of the pegmatite bodies explored for beryl, a Fe-Mn phosphate associations occur as centimetric nodules and aggregates. Two phosphate associations were characterized: the first, hosted in Pichorra and São Júlio pegmatites present three primary phases, identified as zweiselite, sarcopside and F-apatite. Hydrothermal processes transform the primary phosphates in rockbridgeite, heterosite and a phase of the alluaudite subgroup. The second association was observed in the Fazenda Mesquita pegmatite, where primary phosphates are absent and orange to green rockbridgeite is the main phase, followed by phosphosiderite and strengite formed by the weathering of rockbridgeite. In both associations, the weathering of the Fe-Mn phosphates give rise to $\mathrm{Fe}$ and $\mathrm{Mn}$ oxides.. Minor phases as uraninite, gahnite, almandine and columbite (Fe) were identified as inclusions in the phosphate phases.
\end{abstract}

Keywords: Fe-Mn phosphates; pegmatites; Mata Azul 


\subsection{INTRODUÇÃO}

O estudo de associações fosfáticas em pegmatitos é sensível aos diferentes estágios de evolução do corpo (Fransolet 2007). Indicações do estágio de evolução do magma pegmatítico utilizando o teor de elementos como Li, F, P, e a razão Fe/Mn

podem ser dados por fosfatos primários, por exemplo. Alterações hidrotermais e intempéricas de fosfatos pré-existentes podem ainda aumentar consideravelmente o número de fases fosfáticas existentes, resultando em complexas paragêneses de grande interesse mineralógico.

Na parte central do Brasil vários corpos pegmatíticos ocorrem espalhados por uma área que abrange os estados de Goiás e Tocantins. Muitos destes pegmatitos hospedaram garimpos de gemas por várias décadas, mas hoje, a grande maioria se encontra abandonada. No sul do estado do Tocantins, no município de Jaú do Tocantins, alguns garimpos extintos de berilo (industrial e gema) foram visitados para descrição mineralógica. Apesar de estarem totalmente entupidos ou cobertos de água, no rejeito de três garimpos, Pichorra, São Júlio e Fazenda Mesquita, vários fragmentos de agregados de fosfatos foram encontrados na forma de nódulos e massas centimétricas. Vários trabalhos sobre fosfatos em pegmatitos já foram descritos na Província Pegmatítica Oriental, em Minas Gerais (Chaves et al. 2005, Scholz 2006, Chaves \& Scholz 2008, Baijot et al. 2014, Chukanov et al. 2014) e nestes pegmatitos pouco estudados do Brasil Central, esta é a primeira descrição de uma assembléia de fosfatos de Fe e Mn.

\subsection{SÍNTESE GEOLÓGICA}

Os pegmatitos portadores dos fosfatos de $\mathrm{Fe}$ e $\mathrm{Mn}$ estão localizados na parte central da Provínica Tocantins, que compreende um sistema orogênico formado por extensas faixas de dobramentos, entre elas, a Faixa Brasília, no qual a área de estudo está inserida, localizada no município de Jaú do Tocantins, próxima à divisa com o estado de Goiás (figura 3.1).A região possui um embasamento metassedimentar de fácies anfibolito denominado Formação Ticunzal, constituído por diferentes tipos de xisto e paragnaisses. Alvarenga et al. (2007) inserem rochas da formação Ticunzal, aflorantes à SE da área de estudo, no Paleoproterozoico. Intrudindo este embasamento estão as suítes Aurumina e Rio das Almas, a primeira compreende rochas graníticas 
peraluminosas foliadas, a segunda suíte é constituída por granodioritos e gnaisses (Araújo Filho et al. 2016). O Grupo Serra da Mesa, com idade de deposição estimada entre 1.47 e 1.57 Ga (Dardenne 2000; Marques 2009), cobre boa parte da região com rochas metassedimentares sílico-carbonáticos deformadas e metamorfisadas durante a orogenia Brasiliana no neoproterozóico. A suíte do Peixe, intrusiva no grupo Serra da Mesa é formada por sienogranitos, nefelina sienitos e pegmatitos alcalinos de 1.5 a 1.47Ga (Kitajima 2001), que não são relacionados aos pegmatitos aqui estudados.

Os pegmatitos portadores de fosfatos de Fe e Mn, conforme proposto por Queiroz (2017,), são relacionados à suíte Mata Azul, composta por leucogranitos evoluídos do neoproterozoico, associados à evolução do Arco Magmático de Mara Rosa. A ocorrência desses granitos só é conhecida no norte do estado de Goiás, nas proximidades da divisa com o estado de Tocantins, não tendo sido até agora mapeados na região de ocorrência dos fosfatos.

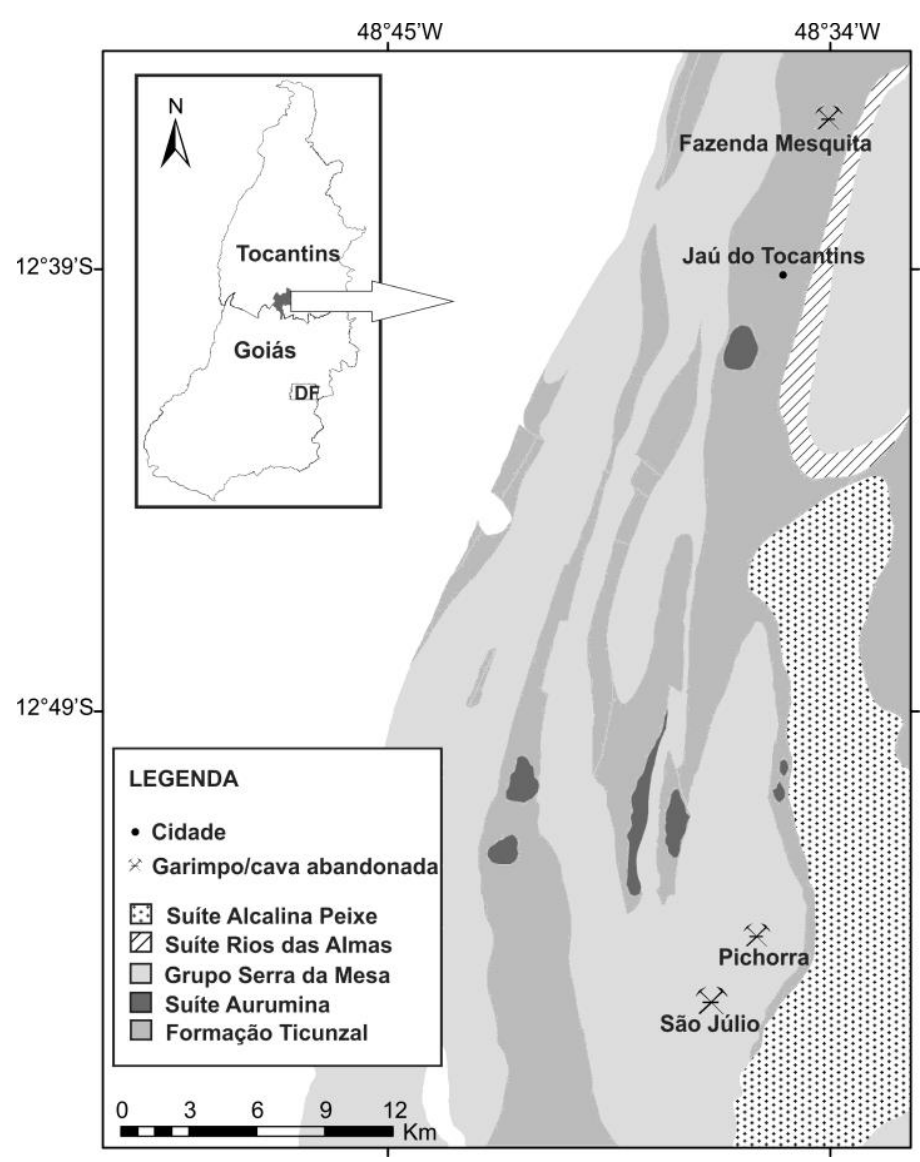

Figura 3. 1: Mapa geológico com a localização dos pegmatitos hospedeiros de fosfatos 


\subsection{MÉTODOS ANALÍTICOS}

Várias seções delgadas das massas de fosfato foram confeccionadas para os estudos das fases minerais, primeiramente com a observação e descrição das paragêneses sob microscópio de luz polarizada.

Análises químicas pontuais foram feitas em uma sonda eletrônica JEOL, modelo superprobe JXA-8230, utilizando voltagem de $15 \mathrm{Kv}$ e corrente de $10 \mathrm{nA}$. Os padrões empregados foram: albita $(\mathrm{Na})$, microclínio $(\mathrm{K}, \mathrm{Al}), \mathrm{ZnO}$ vidro $(\mathrm{Zn})$, forsterita $(\mathrm{Mg})$, andradita $(\mathrm{Si}, \mathrm{Ca}, \mathrm{Fe})$, topázio $(\mathrm{F})$, pirofanita $(\mathrm{Mn})$ e apatita $(\mathrm{P})$. Imagens por microscópio eletrônico de varredura foram feitas em um aparelho FEI Quanta 450.

Análises de micro Raman utilizaram um espectrômetro triplo Jobin Yvonspex Horiba, modelo T64000, com objetiva de 50x e detector CCD refrigerado a nitrogênio líquido, e o espectro Raman foi excitado por um laser de Argônio (514.5nm) com potência de saída de $100 \mathrm{~mW}$ e filtro de plasma na linha de $514.5 \mathrm{~nm}$. O tempo de aquisição foi de 10 segundos com integração de $3 \mathrm{x}$.

A identificação de fases por meio da difração de raios $X$ foi realizada em um difratômetro Rigaku modelo Ultima IV, com tubo de cobre, filtro de níquel em $35 \mathrm{kV}$ e $15 \mathrm{~mA}$, e a varredura da amostra foi feita em $5^{\circ} /$ minuto no intervalo $2 \theta$ de 3 a $80^{\circ}$.

\subsection{OS PEGMATITOS DO SUBTIPO BERILO-COLUMBITA-FOSFATO}

Os pegmatitos com ocorrências de fosfatos de Fe e Mn pertencem à família LCT e fazem parte de um grupo de pegmatitos explorados para berilo (gemológico principalmente), do subtipo berilo-columbita-fosfato segundo classificação de Černý \& Ercit (2005), e compõem o campo pegmatítico da Suíte Mata Azul (Queiroz 2017).

Os pegmatitos que hospedam os fosfatos já foram alvo de garimpeiros em busca de berilo, em especial água-marinha. Estes corpos possuem exposição limitada, estando há muito tempo encobertos pela vegetação ou por água. Os diques pegmatíticos apresentam-se bastante alterados constituindo-se principalmente por caulim, com quantidades variáveis de muscovita, quartzo e raramente biotita. Nas pilhas de rejeito, cristais de feldspato potássico ainda pouco alterado podem ser encontrados, junto de grandes blocos de quartzo com muscovita e berilo, na maior parte de coloração verde clara a azul clara, com alguns poucos cristais tendendo a cor amarela. No pegmatito São 
Júlio, cristais de schorlita também são facilmente encontrados além de fragmentos de um agregado de micro cristais de muscovita de coloração verde clara.

Os fosfatos são encontrados sob a forma de nódulos e massas contendo em grande parte duas ou mais fases minerais. Apesar das amostras não estarem in situ, presume-se que são produtos finais da cristalização do corpo pegmatítico devido a ocorrência em conjunto com grande blocos de quartzo, típicos das zonas mais internas do pegmatito. Outras fases minerais podem ser encontradas dentro das massas fosfáticas, por exemplo, almandina, uraninita, gahnita e Fe-columbita, sempre em pouca quantidade., Além destes minerais, óxidos e hidróxidos de Fe e Mn preenchem fraturas e envolvem alguns nódulos e massas de fosfatos.

Tabela 3. 1: Composição química de alguns minerais dos pegmatitos portadores de berilo e fosfato.

\begin{tabular}{|c|c|c|c|}
\hline & Schorlita & Almandina & Muscovita \\
\hline $\mathrm{SiO}_{2}$ & 34.69 & 34.97 & 45.57 \\
\hline $\mathrm{TiO}_{2}$ & 0.37 & & 0 \\
\hline $\mathrm{Al}_{2} \mathrm{O}_{3}$ & 30.84 & 22.13 & 34.50 \\
\hline $\mathrm{FeO}$ & 16.45 & 31.41 & 3.63 \\
\hline $\mathrm{MnO}$ & 2.30 & 10.71 & 0.10 \\
\hline $\mathrm{MgO}$ & 0.14 & 0.11 & 0.31 \\
\hline $\mathrm{CaO}$ & 0.01 & 0.05 & 0.01 \\
\hline $\mathrm{Na}_{2} \mathrm{O}$ & 2.74 & & 0.65 \\
\hline $\mathrm{K}_{2} \mathrm{O}$ & 0.02 & & 10.27 \\
\hline $\mathrm{F}$ & 0.71 & & 1.54 \\
\hline $\mathrm{H}_{2} \mathrm{O}^{*}$ & 3.17 & & 3.73 \\
\hline $\mathrm{B}_{2} \mathrm{O}_{3}{ }^{*}$ & 10.17 & & \\
\hline $\mathrm{Li}_{2} \mathrm{O}^{*}$ & 0.13 & & 0.40 \\
\hline Total & 101.43 & 99.38 & 100.05 \\
\hline \multirow[t]{2}{*}{$\mathrm{O}=\mathrm{F}$} & 0.30 & & 0.65 \\
\hline & \multicolumn{2}{|c|}{ Átomos por fórmula unitária } & \\
\hline $\mathrm{Si}$ & 5.931 & 2.886 & 6.123 \\
\hline $\mathrm{Ti}$ & 0.048 & & 0 \\
\hline Al & 6.214 & 2.164 & 5.465 \\
\hline $\mathrm{Fe}$ & 2.352 & 2.233 & 0.408 \\
\hline $\mathrm{Mn}$ & 0.333 & 0.749 & 0.011 \\
\hline $\mathrm{Mg}$ & 0.036 & 0.014 & 0.061 \\
\hline $\mathrm{Ca}$ & 0.002 & 0.004 & 0.002 \\
\hline $\mathrm{Na}$ & 0.908 & & 0.169 \\
\hline $\mathrm{K}$ & 0.004 & & 1.760 \\
\hline $\mathrm{F}$ & 0.384 & & 0.654 \\
\hline $\mathrm{OH}$ & 3.616 & & 3.346 \\
\hline B & 3 & & \\
\hline $\mathrm{Li}$ & 0.087 & & 0.218 \\
\hline
\end{tabular}




\subsection{PETROGRAFIA DOS FOSFATOS}

Existem duas associações de fosfatos nos pegmatitos visitados, a primeira é encontrada nos garimpos Pichorra e São Júlio e é caracterizada pela presença de fases primárias e secundárias de fosfatos. Na segunda associação, encontrada nos agregados do pegmatito Fazenda Mesquita, apenas fases secundárias puderam ser identificadas.

\subsubsection{Associação de Fosfatos I}

Boa parte das amostras da associação I é formada por massas anédricas de uma fase dentro da solução sólida zwieselita $(\mathrm{Fe}, \mathrm{Mn})_{2}\left(\mathrm{PO}_{4}\right) \mathrm{F}$ - triplita $(\mathrm{Mn}, \mathrm{Fe}, \mathrm{Mg}, \mathrm{Ca})_{2}\left(\mathrm{PO}_{4}\right)(\mathrm{F}, \mathrm{OH})$, com maior tendência para a composição da zwieselita (figura 3.2). Este fosfato de coloração bege a castanha clara e, algumas vezes, salmão, corresponde a fase de fosfato dominante e pode ser considerado como de origem primária, assim como cristais euédricos a subédricos de flúor-apatita que abundam em algumas porções das amostras estudadas (figura 3.3).

Os cristais de zwieselita comumente mostram alterações com padrões variados. $\mathrm{O}$ primeiro deles tem aspecto "mosqueado" de difícil identificação e provavelmente corresponde a uma primeira etapa de alteração. Progressivamente, o fosfato primário dá lugar a massas de heterosita $-\left(\mathrm{Fe}^{3+}, \mathrm{Mn}^{3+}\right) \mathrm{PO}_{4}$, inicialmente com coloração vermelha escura passando a roxa ou púrpura (figura 3.3). Óxidos de Fe e/ou Mn podem também se formar junto à massa de heterosita.

Duas fases minerais se formam a partir da alteração da heterosita e ocorrem juntas em um agregado de finos cristais com coloração amarela a laranja em limitadas áreas das amostras coletadas (figura 3.3). Os cristais amarelos mostram composição química similar à série frondelita-rockbridgeíta $-\left(\mathrm{Mn}^{2+} \mathrm{Fe}^{2+}\right) \mathrm{Fe}_{3+} 4\left(\mathrm{PO}_{4}\right)_{3}(\mathrm{OH})_{6}$, com tendência para composição mais rica em Fe da rockbridgeíta. Os cristais laranja, mais abundantes, são por sua vez identificados como uma fase mineral do grupo da alluaudita- willyeita e talvez um membro da série varulita - $(\mathrm{Na}, \mathrm{Ca}) \mathrm{Mn}^{2+}\left(\mathrm{Mn}^{2+}, \mathrm{Fe}^{2+}, \mathrm{Fe}^{3+}\right)_{2}\left(\mathrm{PO}_{4}\right)_{3}-$ hagendorfita $-\mathrm{NaCaMn}^{2+}\left(\mathrm{Fe}^{2+}, \mathrm{Fe}^{3+}, \mathrm{Mg}\right)_{2}\left(\mathrm{PO}_{4}\right)_{3}$, incluso no subgrupo da alluaudita.

Em determinadas porções das amostras ocorre uma associação de heterosita, minerais do subgrupo da alluaudita e sarcopsídeo - $\left(\mathrm{Fe}^{2+}, \mathrm{Mn}^{2+}, \mathrm{Mg}\right)_{3}\left(\mathrm{PO}_{4}\right)_{2}$. Sarcopsídeo aparece sob a forma de lamelas incolores em duas direções distintas (figura 
3.3), como se acompanhasse planos de clivagem. Em algumas lamelas de sarcopsídeo, o cristal mostra-se parcialmente alterado, com finas vênulas de oxidação, até ser totalmente substituído por minerais do subgrupo da alluaudita.

Substituindo os fosfatos ou preenchendo fraturas abundam muitos óxidos. Aqueles compostos predominantemente por Fe podem formar agregados centimétricos de hematita, enquanto as fases com $\mathrm{Mn}$ e algum conteúdo de $\mathrm{K}$ ou $\mathrm{Ba}$ indicam ocorrências de criptomelano e hollandita respectivamente.

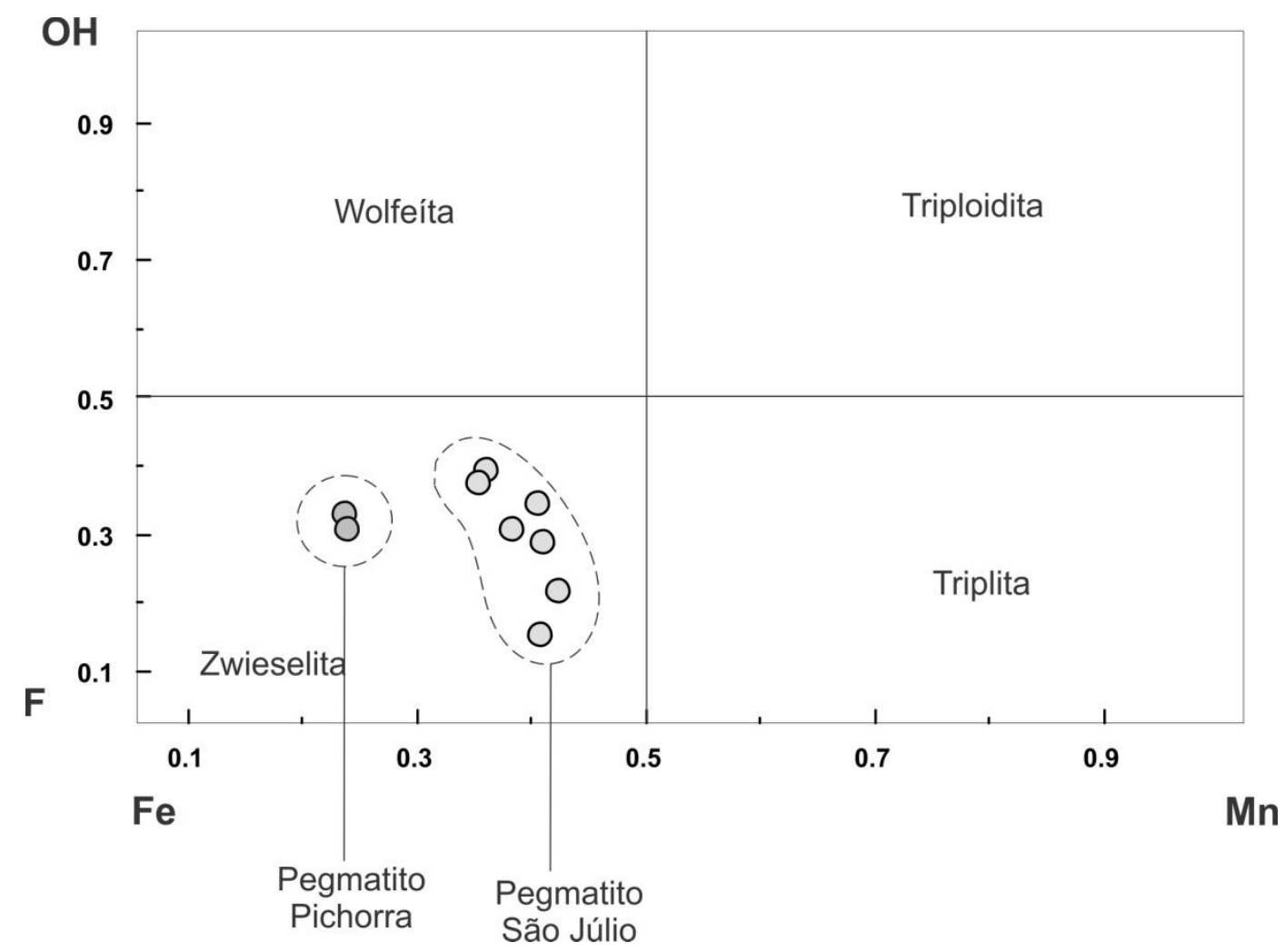

Figura 3. 2: Classificação do fosfato primário zwieselita na associação I. Valores em apfu. 

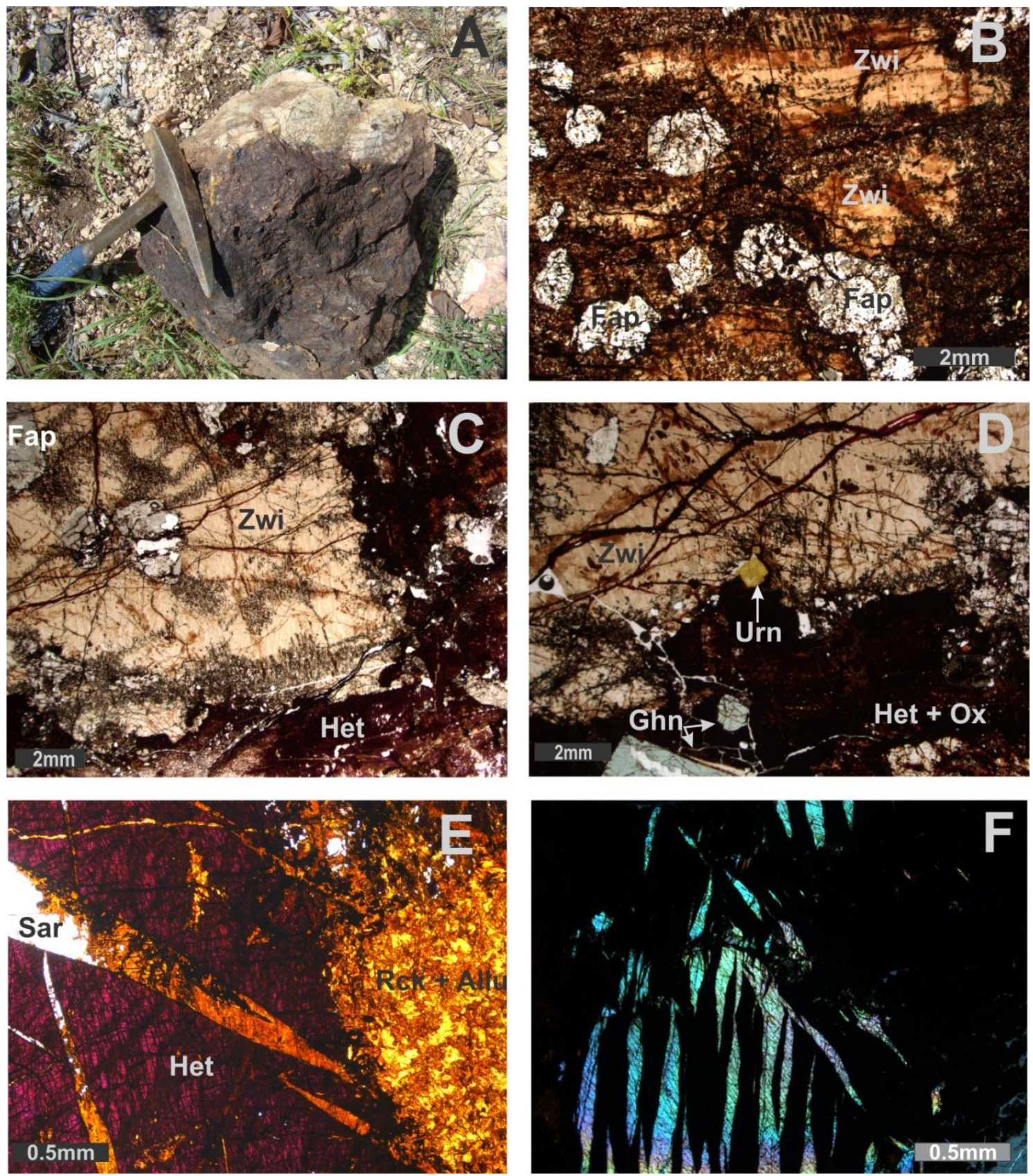

Figura 3. 3: Fosfatos da associação I. A: bloco com quartzo e agregado maciço de fosfatos (P//). B: cristal de zwieselita castanho em estágio de alteração (aspecto granulado) e cristais brancos de flúor-apatita. C: zwieselita castanha alterando para massa de heterosita avermelhada. D: zwieselita castanha, com massa de alteração composta por heterosita e óxidos de Mn e Fe, além de cristal cúbico amarelo de uraninita no centro da imagem e cristais azulados de gahnita na parte inferior. E: associação com heterosita roxa, lamelas de sarcopsídeo incolor, alterando-se para minerais do grupo da alluaudita de cor laranja e massa laranja e amarela constituída por minerais do grupo da alluaudita e rockbridgeita. F: lamelas de sarcopsídeo em massa de heterosita + opacos (PX). Zwi: zwieselita, Fap: flúor-apatita, Het: heterosita, Urn: uraninita, Ghn: gahnita, Ox: óxidos, Rck: rockbridgeita, Sar: sarcopsídeo, Allu: minerais do subgrupo da alluaudita. 


\subsubsection{Associação de Fosfatos II}

A associação de Fosfatos II está presente em amostras do pegmatito da Fazenda Mesquita, na qual não foram encontrados indícios de fosfato primário. O grau de alteração em algumas massas fosfáticas é tal que uma crosta de óxidos e hidróxidos de Fe é formada, constituída principalmente por goethita, que mostra um hábito reniforme típico. Óxido de Mn também é comumente encontrado, preenchendo fraturas ou sob a forma de finas crostas.

Grande parte do volume de fosfatos é formada por um agregado anédrico, ou radial em algumas porções, de rockbridgeíta verde escura (figura 3.4) que pode, pontualmente, adquirir coloração laranja devido a um maior grau de oxidação, sem modificação importante na constituição química.

Rockbridgeíta se altera principalmente para fosfosiderita $-\mathrm{Fe}^{3+} \mathrm{PO}_{4} \cdot 2 \mathrm{H}_{2} \mathrm{O}$, que forma massas anédricas de cor bege a amarelada até aglomerados botrioidais (figura 3.4). Nos agregados de fosfatos é comum a ocorrência de pequenas cavidades, em geral com poucos centímetros, envoltas por rockbridgeíta e fosfosiderita. Estas cavidades, em sua maior parte, possuem cristais prismáticos bem formados de strengita - $\mathrm{Fe}^{3+} \mathrm{PO}_{4} \cdot 2 \mathrm{H}_{2} \mathrm{O}$, (figura 3.4) que também podem assumir a forma de pequenos esferulitos, com coloração variando entre branca, rosa e roxa, muitas vezes em um mesmo cristal. Os resultados de espectroscopia Raman (figura 3.5) ajudam a diferenciar entre os polimorfos fosfosiderita e strengita, baseando-se no trabalho de Frost et al. (2004) e no banco de dados RRUFF. 

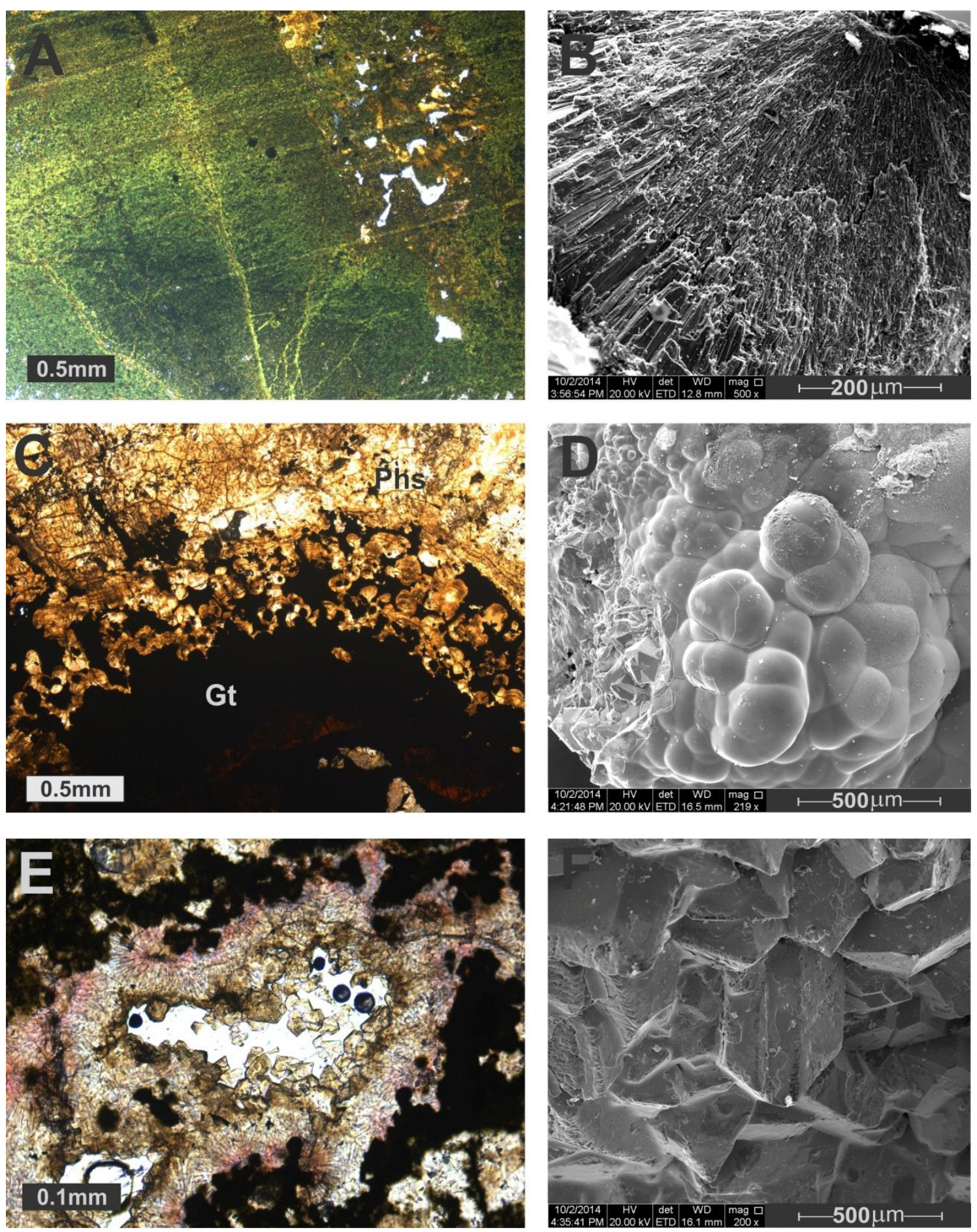

Figura 3. 4: Fotomicrografias e imagens por MEV da associação II. A: massa anédrica verde de rockbridgeita. B: aspecto radial da rockbridgeíta em algumas porções das amostras. C: fosfosiderita amarelada maciça na parte superior da foto passando a pequenos esferulitos no centro, na porção inferior uma massa de alteração formada por goethita. D: aspecto botrioidal da fosfosiderita em uma cavidade. E: Cristais esferulíticos e prismáticos de strengita. F: aspecto prismático de cristal de strengita em cavidade. Phs: fosfosiderita, Gt: goethita. 
Tabela 3. 2: Composição representativa de fosfatos das associações I e II.

\begin{tabular}{|c|c|c|c|c|c|c|c|c|}
\hline & Zwieselita & Sarcopsídeo & Heterosita roxa & $\begin{array}{l}\text { Subgrupo da } \\
\text { Alluaudita }\end{array}$ & $\begin{array}{l}\text { Rockbridgeíta } \\
\text { verde }\end{array}$ & $\begin{array}{c}\text { Fosfosiderita } \\
\text { bege }\end{array}$ & Strengita rosa & F-Apatita \\
\hline $\mathrm{P}_{2} \mathrm{O}_{5}$ & 31.78 & 39.46 & 47.62 & 46.04 & 35.04 & 43.48 & 42.12 & 41.44 \\
\hline $\mathrm{FeO}$ & 34.92 & 44.43 & & $3.24 *$ & $3.71 *$ & & & 0.93 \\
\hline $\mathrm{Fe}_{2} \mathrm{O}_{3}$ & & & 40.01 & 16.77 & 47.33 & 45.74 & 40.27 & \\
\hline $\mathrm{MnO}$ & 24.21 & 12.04 & & 25.85 & 7.52 & 0.61 & 1.65 & 1.69 \\
\hline $\mathrm{Mn}_{2} \mathrm{O}_{3}$ & & & 11.24 & & & & & \\
\hline $\mathrm{MgO}$ & 1.2 & 0.19 & 0.25 & 0.22 & 0.00 & 0.03 & 0.00 & \\
\hline $\mathrm{CaO}$ & 0.79 & 0.01 & 0.38 & 0.16 & 0.07 & 0.03 & 0.02 & 53.08 \\
\hline $\mathrm{Na}_{2} \mathrm{O}$ & 0.12 & 0.04 & & 8.35 & 0.17 & 0.12 & 0.06 & \\
\hline $\mathrm{K}_{2} \mathrm{O}$ & & 0.01 & 0.89 & 0.14 & 0.00 & 0.02 & 0.07 & \\
\hline $\mathrm{F}$ & 6.53 & & & & & & & 3.44 \\
\hline $\mathrm{O}=\mathrm{F}$ & 2.75 & & & & & & & 1.45 \\
\hline \multirow[t]{2}{*}{ Total } & 96.80 & 96.19 & 100.39 & 100.77 & 92.49 & 90.03 & 84.19 & 99.13 \\
\hline & & & \multicolumn{3}{|c|}{ Átomos por fórmula unitária } & & & \\
\hline $\mathrm{P}$ & 0.931 & 2.037 & 0.966 & 3.125 & 3.133 & 1.020 & 1.048 & 2.881 \\
\hline $\mathrm{Fe}^{2}$ & 1.010 & 2.265 & & 0.217 & 0.327 & & & 0.064 \\
\hline $\mathrm{Fe}^{3}$ & & & 0.721 & 1.012 & 3.762 & 0.954 & 0.890 & \\
\hline $\mathrm{Mn}^{2}$ & 0.710 & 0.622 & & 1.755 & 0.673 & 0.014 & 0.041 & 0.118 \\
\hline $\mathrm{Mn}^{3}$ & & & 0.314 & & & & & \\
\hline $\mathrm{Mg}$ & 0.062 & 0.017 & 0.010 & 0.026 & & 0.001 & & \\
\hline $\mathrm{Ca}$ & 0.029 & 0.001 & 0.010 & 0.014 & 0.008 & 0.001 & 0.001 & 4.670 \\
\hline $\mathrm{Na}$ & 0.008 & 0.005 & & 1.298 & 0.033 & 0.006 & 0.003 & \\
\hline $\mathrm{K}$ & & 0.001 & 0.027 & 0.014 & & 0.001 & 0.003 & \\
\hline $\mathrm{F}$ & 0.715 & & & & & & & 0.893 \\
\hline
\end{tabular}

subgrupo da alluaudita e apatita e 14.5 oxigênios para rockbridgeíta.

*valores calculados. 


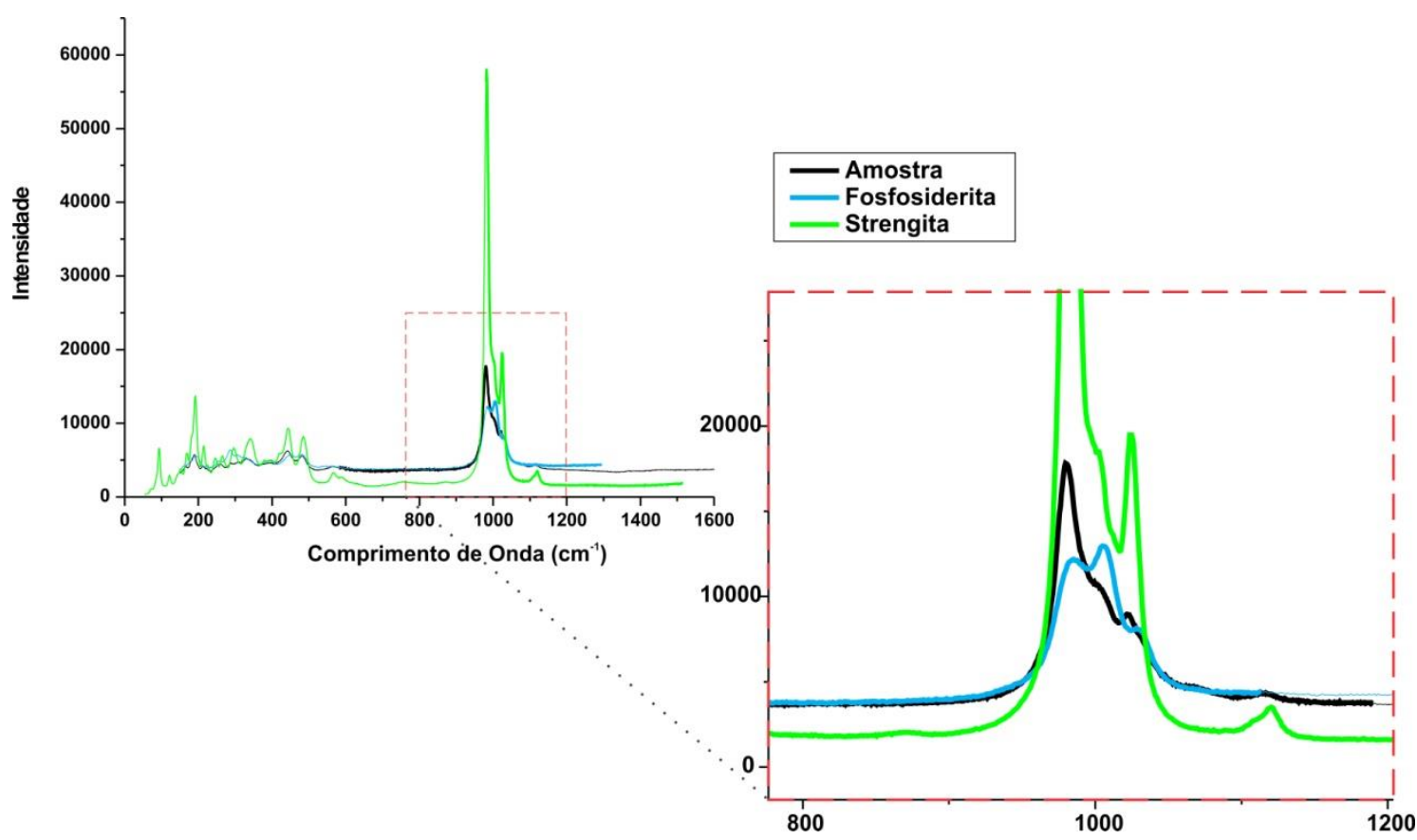

Figura 3. 5: Espectro Raman de uma amostra de cavidade comparada a fosfosiderita e strengita do banco de dados $R R U F F$, com detalhe para a faixa entre 800 e $1200 \mathrm{~cm}^{-1}$, onde os picos são mais distintivos.

\subsection{DISCUSSÕES E SEQUENCIA DE ALTERAÇÃO}

Três fases primárias fazem parte da associação I de fosfatos, são elas: zwieselita, a mais abundante, sarcopsídeo e apatita. London et al. (1999) em trabalho experimental com fases silicáticas e fosfáticas discutem que o alto conteúdo inicial de $\mathrm{Ca}$ e $\mathrm{F}$ em uma triplita pode promover a saturação do melt nestes elementos, o que explicaria a ocorrência aqui observada, de F-apatita em equilíbrio com a zwieselita.

Moore (1972) sugere a existência de uma solução sólida de alta temperatura para o intercrescimento entre sarcopsídeo e trifilita, na qual o sarcopsídeo é derivado da estrutura da trifilita (Moore 1984). Entre as ocorrências conhecidas desta associação pode-se citar aquela descrita por Roda Robles et al. (2014). Como já descrito, lamelas de sarcopsídeo são encontradas junto a massas de heterosita de origem secundária, o que indica que o fosfato primário da qual o sarcopsídeo se exsolveu já foi totalmente alterado, podendo ter sido a trifilita ou talvez a zwieselita, que foi identificada nos pegmatitos da associação I.

A partir da zwieselita, massas de heterosita se formam por alteração hidrotermal, inicialmente como pequenas inclusões no fosfato primário. A heterosita nos estágios 
menos alterados tem uma coloração vermelha escura, que por vezes chega a tons tão escuros que se assemelham a minerais opacos, em alguns casos, há de fato uma mistura de óxidos de $\mathrm{Fe}$ e Mn e fosfatos nessas massas escuras, porções de heteroista roxa a púrpura aparecem quando esta fase é intermediária com a purpurita. O flúor da zwieselita é lixiviado, Fe é oxidado e é provável que em estágios mais avançados de alteração, naqueles cristais de cor roxa, o Mn se oxide.

Os cristais de sarcopsídeo parecem resistir melhor à primeira fase de alteração, apenas algumas vênulas de óxido de ferro são observadas ao longo dos planos de clivagem dos cristais.

Em áreas bem localizadas dos nódulos de fosfatos da associação I, outro tipo de alteração tardia está presente, neste caso gerando um metassomatismo com entrada de Na. Este tipo de alteração em especial parece cobrir apenas porções restritas e, como não há amostras in situ, é difícil associá-la uma paragênese mineral específica ou uma zona do pegmatito. Ela é formada predominantemente por cristais do subgrupo da alluaudita, pela química mineral, possivelmente de um membro da série varulita hagendorfita.

Os óxidos de $\mathrm{Fe}$ e $\mathrm{Mn}$ podem se formar em vários estágios de alteração, mas principalmente na fase mais tardia de oxidação, preenchendo fraturas e formando crostas.

$\mathrm{Na}$ associação de fosfatos II, todo o fosfato primário que não foi encontrado parece ter se transformado em rockbridgeíta, muito provavelmente por alteração hidrotermal. A rockbridgeíta por processo subseqüente de oxidação se transforma em fosfosiderita, e quando em contato com cavidades pré-existentes, a strengita é o fosfato gerado. Outros produtos da oxidação intempérica são os óxidos e hidróxidos de $\mathrm{Mn}$ e Fe, principalmente a goethita que forma crostas e massas junto aos fosfatos, em muitas porções este hidróxido de Fe apresenta um hábito reiniforme típico, e ao mesmo tempo herdado da rockbridgeíta (figura 3.4). 


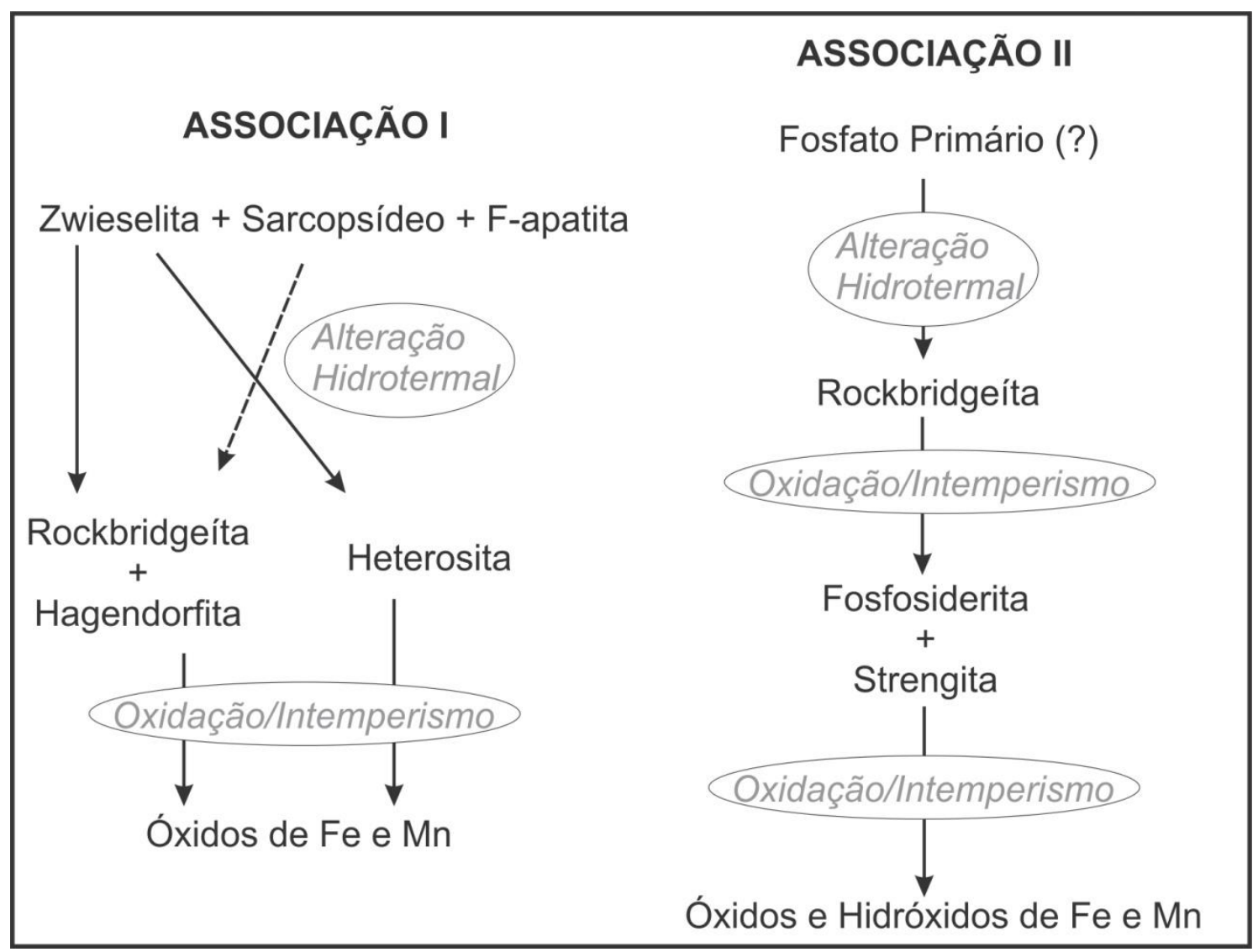

Figura 3. 6: Esquema de alteração para as associações de fosfatos. 
CONCLUSÕES 


\section{Capítulo 4}

\section{Conclusões}

As principais conclusões baseadas nos estudos geológicos, petrográficos, mineralógicos e geoquímicos realizados:

- Uma série de pegmatitos graníticos ocorre nos municípios de Montividiu do Norte, Jaú do Tocantins, São Salvador do Tocantins e Palmeirópolis, estes corpos intrudem na maior parte, rochas metassedimentares de grau anfibolito, pertencentes a formação Ticunzal e ao grupo Serra da Mesa e mostram um alongamento no sentido NE-SW, e em escala regional é possível observar um possível alinhamento neste mesmo sentido.

- Foram distinguidos três tipos de pegmatitos: i; estéreis, ii; pegmatitos explorados para berilo e iii; pegmatitos explorados para turmalina, os tipos mineralizados ocorrem em agrupamentos bem definidos espacialmente.

- Os pegmatitos portadores de berilo: Pichorra, São Júlio, Onça e Fazenda Mesquita possuem como principais acessórios: berilo, de cor verde a azul, e alguns raros cristais amarelos de heliodoro, granada da variedade almandina, esta ocorrendo principalmente no pegmatito Onça sob a forma de agregados de cristais euédricos, schorlita, fosfatos de Fe e Mn (com exceção do pegmatito Onça), uraninita e gahnita (S.Júlio) e Fecolumbita.

- Os fosfatos de Fe e $\mathrm{Mn}$ descritos compreendem duas associações distintas: a primeira composta pelas fases primárias: zwieselita, sarcopsídeo e F-apatita, que se alteram para rockbridgeíta, hagendorfita e heterosita, esta associação é presente nos pegmatitos São Júlio e Pichorra. A segunda associação é formada apenas por fases de alteração, principalmente rockbridgeíta, além desta, fosfosiderita e strengita aparecem em menor proporção, o pegmatito Fazenda Mesquita hospeda esta paragênese. Em ambas as associações óxidos e hidróxidos de Fe e Mn aparecem em proporções variáveis. 
- Uraninita do pegmatito São Júlio datada quimicamente utilizando a metodologia de Bowles (1990) indicou valores situados entre 400 e $560 \mathrm{Ma}$, com uma freqüência maior de idades entre 500 e 560Ma.

- Dentre os pegmatitos explorados para turmalina, dois grupos puderam ser distinguidos, meridionais (Jóia da Mata, Córrego das Pedras, “4”, "5" e "6") e setentrionais (Marimbondo, Marimbondinho, Índio, Zé do Fole, Boanerges, Marta Rocha e Berilão), no primeiro, a mineralogia é mais simples com acessórios mais importantes a trilitionita, schorlita e elbaítas azuis e verdes, algumas vezes zonadas. Os corpos setentrionais possuem mineralogia mais diversificada, com exceção do pegmatito Berilão, como acessórios principais pode-se citar a schorlita, elbaíta, trilitionita, montmorillonita, berilo (branco até rosado) e alguns raros cristais de espodumênio.

- Cristais de monazita foram datados pelo método U-Pb com idade calculada em $519,9 \pm 2,8 \mathrm{Ma}$.

- Halos de alteração causados pela intrusão dos pegmatitos não são facilmente observados nos corpos mineralizados, em lâmina delgada é possível em alguns casos visualizar pequenos cristais de dravita formados pela interação entre componentes magmáticos e da rocha encaixante.

- A alteração causada por apófises pegmatíticas simples gerou metamorfismo de contato no corpo denominado "17". O halo de alteração substituiu boa parte da mineralogia da rocha encaixante, um paragnaisse, principalmente no contato com a intrusão onde a temperatura era maior. A mineralogia produzida inclui: diopsídio, hedenbergita, anfibólio cálcico, allanita, titanita, granada, rutilo, ilmenorutilo, Y-policrásio e como produtos de alteração: carbonato, fluorita e óxidos de ferro.

- Posteriormente ao metamorfismo de contato uma fase hidrotermal causou silicificação de parte do paragnaisse e do pegmatito além da formação de sulfetos, principalmente pirrotita, com pouca calcopirita. Com a percolação de água meteórica pelas fraturas, sulfatos como alunogen e pickeringita se formaram a partir dos sulfetos pré-existentes. 
- Um granito pegmatítico da suíte Mata Azul aflorante no canto sudoeste da área de estudo é o mais provável como o granito fonte dos pegmatitos estudados. As características geoquímicas e texturais desta suíte, considerando as idades químicas e isotópicas tratadas neste trabalho, configuram esta suíte como o provável granito parental.

- $\mathrm{Na}$ área de estudo é possível reconhecer um possível sistema evolutivo granito-pegmatito, onde o fracionamento químico é responsável pela geração de corpos menos diferenciados (ex: leucogranito Mata Azul) ou mais diferenciados (ex: Pegmatito Zé do Fole). A separação do grau de fracionamento dos corpos pôde ser feito com base na associação mineral, e química mineral de algumas variedades presentes em corpos de diferentes graus de evolução, como por exemplo, a granada e o berilo. 
REFERÊNCIAS BIBLIOGRÁFICAS 


\section{Referências Bibliográficas}

Alexandre, P. \& Kyser, T.K. 2005. Effects of cationic substitutions and alteration in uraninite, and implications for the dating of uranium deposits. The Canadian Mineral. 43: 1005-1017.

Almeida, F.F.M., Hasui, Y., Brito Neves, B.B., Fuck, R.A. 1981. Brazilian structural provinces: an introduction. Earth-Sci. Reviews. 17: 1-29.

Alvarenga, C.J.S., Botelho, N.F., Dardenne, M.A., Lima, O.N.B., Machado, M.A. 2007. Programa geologia do Brasil: Geologia da folha Cavalcante, 1:100000. Nota explicativa, Goiás, UnB/CPRM. $67 \mathrm{p}$.

Araújo Filho, O \& Toledo, C.L., Carmelo, A.C., Almeida, T., Ferreira, G. 2017. In preparation

Baijot, M., Hatert, F., Dal Bo, F., Philippo, S., 2014. Mineralogy and petrography of phosphate mineral associations from the Jocão Pegmatite, Minas Gerais, Brazil. Canadian Mineral. 52: 373-397.

Baldwin, J. R. \& Knorring, O. 1983. Compositional range of Mn-garnet in zoned granitic pegmatites. The Canadian Mineral. 21: 683-688.

Beurlen, H., Rhede, D., Silva, M.R.R., Thomas, R., Guimarães, I.P. 2009. Petrography, geochemistry and chemical electron microprobe $\mathrm{U}-\mathrm{Pb}-\mathrm{Th}$ dating of pegmatittic granites in Borborema Province, northeastern Brazil: a possible source of the rare element granitic pegmatites. Terrae. 3(2): 65-74.

Beurlen, H., Silva, M.R.R., Thomas, R., Soares, D.R., Olivier, P. 2008. Nb-Ta-(Ti-Sn) oxide mineral chemistry as tracer of rare element granitic pegmatite fractionation in the Borborema province, northeastern Brazil. Miner Deposita. 43: 207-228.

Botelho, N.F., Fuck, R.A., Dantas, E.L., Laux, J.H., Junges, S.L. 2006. The Paleoproterozoic peraluminous Aurumina granite suite, Goiás and Tocantins, Brazil: geological, whole rock geochemistry and U-Pb and Sm-Nd isotopic constraints. In: Alkmim, F.F., Noce, C.M. (Eds.). The Paleoproterozoic record of the São Francisco Craton, Brazil. Field guide and abstracts. IGCP509: Paleoproterozoic Supercontinents \& Global Evolution. p. 92.

Botelho, N. F., Cunha, L.M., Silva, D.V.G., Pereira, A.B. 2002. Granitos peraluminosos paleoproterozóicos mineralizados em ouro, urânio, estanho e tântalo, na região nordeste de Goiás. In: XLI Congresso Brasileiro de Geologia, João Pessoa.. Anais. Recife: Sociedade Brasileira de Geologia - Núcleo Nordeste, v. 1. p. 436-436. 
Botelho, N. F.; Moura, M. A. 1998. Granite-ore deposit relationship in Central Brazil. Journal of South American Earth Sciences, 11: 427-438.

Botelho, N.F. 1992. Lês ensembles granitiques subalcalins à peralumineux mineralalisés em Sn et In de La Sous-Province Paranã, etat de Goiás, Brésil. PhD Thesis, Université Paris VI, Paris, 344p.

Botelho, N.F., Alvarenga, C.J.S.de, Meneses, P.R., D’el-Rey Silva, L.J.H., 1999. Suíte Aurumina: Uma suíte de granitos paleoproterozoicos, peraluminosos e sin-tectônicos na Faixa Brasília. In: SBG, Simp. Geol. Centro-Oeste, 7, Brasília, Anais p.17.

Bowles, J.F.W. 1990. Age dating of individual grains of uraninite in rocks from electron microprobe analyses. Chemical Geology. 83: 47-53.

Černý, P \& Ercit, T.S. 2005. The classification of granitic pegmatites revisited. The Canadian mineral., 43(6): 2005-2026.

Černý, P. \& Hawthorne, F.C. 1982. Selected peraluminous minerals. In, Černý,P. (ed) Short course in Granite Pegmatites, Min.Assoc.Canada, Handbook 8: 163-186.

Černý, P. 1975. Alkali variations in pegmatitic beryls and their petrogenetic implications. Neus Jahrb. Mineral Abh., 123: 198-212.

Černý, P. 1982. Anatomy and classification of granitic pegmatites In: Černý,P. (ed)Min. Assoc. Canada, Short Course Handbook, 8:1-39.

Černý, P. 1990. Distribution, affiliation and derivation of rare-element granitic pegmatites in the Canadian Shield. Geol. Rundschau, 79: 183-226.

Černý, P. 1991b. Rare-element granitic pegmatites. Part II: Regional to global environments and petrogenesis. Geoscience Canada, 18: 68-81.

Černý P (2002) Mineralogy of beryllium in granitic pegmatites. In: E.S.Grew (editor), Berylium, mineralogy, petrology and geochemistry. Reviews in mineralogy, Mineral Soc. of America. 50: $405-444$.

Chaves, L.M. de S.C., Scholz, R., Atencio, D., Karfunkel, J., 2005. Assembléias e paragêneses minerais singulares nos pegmatitos da região de Galiléia (Minas Gerais). Geociências - UNESP. 24: 143161. 
Chaves, M.L.S.C., Scholz, R., 2008. Pegmatito Gentil (Mendes Pimentel, MG) e suas paragêneses mineralógicas de fosfatos raros. Rem Rev. Esc. Minas . 61: 141-149.

Chukanov, N. V., Scholz, R., Zubkova, N. V., Pekov, I. V., Belakovskiy, D.I., Van, K. V., Lagoeiro, L., Graca, L.M., Krambrock, K., de Oliveira, L.C.A., Filho, L.A.D.M., Chaves, M.L.S.C., Pushcharovsky, D.Y., 2014. Correianevesite, $\mathrm{Fe}^{2+} \mathrm{Mn}_{22} \cdot\left(\mathrm{PO}_{4}\right)_{2} 3 \mathrm{H}_{2} \mathrm{O}$, a new reddingite-group mineral from the Cigana mine, Conselheiro Pena, Minas Gerais, Brazil. Am. Mineral. 99: 811-816.

Cordeiro, P.F.O., Oliveira, C.G., DellaGiustina, M.E.S., Dantas, E.L., Santos, R.V. 2014. The paleoproterozoic Campinorte Arc: tectonic evolution of a central pre-Columbia orogeny. Precambrian Research. 251: 49-61.

Cornejo, C. \& Bartorelli, A. 2010. Minerais e pedras preciosas do Brasil. Solaris Edições Culturais. $704 p$.

Dardenne, M.A. 2000. The Brasília fold belt. In: U.G.Cordani, E.J.Milani, A. Thomaz Filho, D.A.Campos (eds). Tectonic evolution of South America, 31st International Geological Congress, p: 231-263.

Debon, F. \& LeFort, P. 1983. A chemical mineralogical classification of common plutonic rocks and associations. Transactions of Royal Society of Edinburgh, Earth. 73: 135-149.

Dill, H.G. 2015. Pegmatites and aplites: their genetic and applied ore geology. Ore Geology Reviews. 69: 417-561.

Dill, H.G., Kaufhold, S., 2011. A late-stage hydrothermal phosphate- bearing montmorillonite argillitization from the tourmaline-bearing pegmatite of Alto dos Quintos Mine, northeast Brazil. Clay Minerals. 46: 473-485.

Dirlam, D.M., Laurs, B.M., Pezzotta, F.; Simmons, W.B. 2002. Liddicoatite tourmaline from Anjanabonoina, Madagascar. Gems \& Gemology. 38(1): 28-53.

Foord, E.E., Starkey, H.C., and Taggart, J.E., Jr. 1986. Mineralogy and paragenesis of "pocket" clays and associated minerals in complex granitic pegmatites, San Diego, California. American Mineralogist, 71: 428-439.

Frost, R.L., Weier, M.L., Erickson, K.L., Carmondy, O., Mills, S.J. 2004. Raman spectroscopy of phosphates of the variscite mineral group. J.Raman Spectrosc. 35: 1047-1055. 
Fuck, R.A., Dantas, E.L., Pimentel, M.M., Botelho, N.F., Armstrong, R., Laux, J.H., Junges, S.L., Soares, J.E., Praxedes, I.F., 2014. Paleoproterozoic crust-formation and reworking events in the Tocantins Province, central Brazil: A contribution for Atlantica supercontinent reconstruction. Precambrian Research. 244: 53-74.

Henry, D.J. \& Dutrow, B.L. 1996. Metamorphic tourmaline and its petrologic applications. Review in mineralogy and geochem. 33: 503-557.

Henry, D.J., Novak, M., Hawthorne, F.C., Ertl, A., Dutrow, B.L., Uher, P., Pezzota, F. 2011. Nomenclature of the tourmaline-supergroup minerals. American Mineralogist, 96(5-6): 895-913.

Iwanuchi W. 1991. Geologia dos complexos alcalinos proterozóicos do centro do Estado do Tocantins, PhD Thesis, Universidade de São Paulo, 202 p.

Kempe, U. 2003. Precise electron microprobe age determination in altered uraninite: consequences on the intrusion age and the metallogenic significance of the Kirchberg granite (Erzgebirge, Germany). Contrib. Mineral Petrol. 145: 107-118.

Kitajima, L.F.W., Ruiz J., Gehrels, G., Gaspar, J.C. 2001. Uranium-lead ages of zircon megacrysts and zircon included in corundum from Peixe Alkaline Complex (Brazil). In: III Simpósio sudamericano de Geologia Isotópica, Pucón.

Lacerda Filho, J.V., Resende, A.; Silva, A. 1999. Geologia e recursos minerais do estado de Goiás e Distrito Federal. Programa levantamentos geológicos básicos do Brasil. CPRM/METAGO/UnB, Goiânia, Mapa geológico e de recursos mineral, escala 1:500000.

Lamarão, C.N. \& Kotschoubey, B., 1996. Granitóides Santa Luzia : registro do magmatismo granítico Brasiliano do Cinturão Araguaia na região de Paraíso do Tocantins ( TO ). Rev. Bras. Geoc, 26(4): 277-288.

Lima, S.S.M., Neiva, A.M.R., Ramos, J.M.F. 2009. Geochemistry of garnets from a tonalite e granitic aplite-pegmatite veins from Ciborro-Aldeia da Serra, Ossa-Morena zone, southern Portugal. Estudos geológicos, 19(2): 193-197.

London, D. \& Evensen, J.M. 2002. Beryllium in silicic magmas and the origin of beryl-bearing pegmatites. In: E.S.Grew (editor), Berylium, mineralogy, petrology and geochemistry. Reviews in mineralogy, Mineral Soc. of America, 50: 445-486. 
London, D. 2008. Pegmatites. Mineralogical Association of Canada, Special publication (10). 347p.

London, D., Wolf, M.B., Morgan, G.B., Gallego Garrido, M. 1999. Experimental silicate-phosphate equilibria in peraluminous granitic magmas, with a case study of the Albuquerque batholiths at Tres Arroyos, Badajoz, Spain. J.Petrol. 40: 215-240.

Macambira, M.J.B. 1983. Ambiente geológico e mineralizações associadas ao granito Serra Dourada (extremidade meridional) - Goiás. MS Dissertatiton, Universidade Federal do Pará, Belém 132p.

Marini, O. J. , Botelho, N. F. , Rossi, P. 1992. Elementos Terras Raras nos Granitos Estaníferos de Goiás. Revista Brasileira de Geociências. 22(1): 61-72.

Marini, O.J. \& Botelho, N.F. 1986. A província de granitos estaníferos de Goiás. Revista Brasileirade Geociências, 16(1): 119-131.

Marques, G.C., 2009. Geologia dos grupos Araí e Serra da Mesa e seu embasa-mento no sul de Tocantins. Universidade de Brasília, Brasília (MSc Dissertation),120p.

Martin, R.F. \& DeVito, C. 2005. The patterns of enrichment in felsic pegmatites ultimately depend on tectonic setting. The Canadian mineral. 43: 2027-2048.

McCauley, A. \& Bradley, D.C. 2014. The global age distribution of granitic pegmatites. The Canadian Mineralogist. 52: 183-190.

Moore, P.B. 1972. Sarcopside: Its atomic arrangement. American Mineralogist. 57: 24-35.

Moore, P.B. 1984. Cristallochemical aspects of the phosphate minerals In: Nriagu, J.O \& Moore, P.B (eds). Phosphate minerals, p. 137-154.

Nesse, W.D. 2000. Introduction to Mineralogy. Oxford University Press, 433p.

Pereira, A.B. 2002. Caracterização dos granitos e pegmatitos peraluminosos, mineralizados em Sn-Ta de Monte Alegre de Goiás. Ms Dissertation, Universidade de Brasília, Brasília, 60p.

Pimentel, M.M., Rodrigues, J.B., DellaGiustina, M.E.S, Junges, S., Matteini, M., Armstrong, R. 2011. The tectonic evolution of the neoproterozoic Brasília belt, central Brazil, based on SHRIMP and LA-ICPMS U-Pb sedimentary provenance data - A review. Journal of South American Earth Science. 31: 345-357. 
Pimentel, M.M., Fuck, R.A., Jost H., Ferreira Filho, C.F., Araújo, S.M. 2000. The basement of the Brasília Fold Belt and Goiás Magmatic Arc. In: U.G.Cordani, E.J.Milani, A. Thomaz Filho, D.A.Campos (eds). Tectonic Evolution of South America. 31st International Geological Congress, p.: $195-230$.

Pimentel, M.M., Whitehouse, M.J., Viana, M.G., Fuck, R.A., Machado, N. 1997. The Mara Rosa arc in the Tocantins province: further evidence for neoproterozoic crustal accretion in central Brazil. Precambrian Research. 81: 299-310.

Polo, H.J.O. \& Diener, F.S. 2013. Carta geológica: folha Mata Azul SD.22-X-DII. Projeto Noroeste de Goiás, CPRM.

Queiroz, H., Viana, R.R., Battilani, G.A., Oliveira, L.L, Borges, G.M. e Guerra, D.L., 2011. Occurrence of complex pegmatites in the south of tocantins state, Brazil. Asociación Geológica Argentina, publicación especial, 14: 157-159.

Queiroz, H.A. 2017. First description of Fe-Mn phosphates from pegmatites of central Brazil. In preparation.

Roda-Robles, E. Pesquera, A., García de Madinabeitia, S., Gil Ibarguchi, J.I., Nizamoff, J., Simmons, W., Falster, A., Galliski, M.A. 2014. On the geochemical character of primary Fe-Mn phosphates belonging to the triphylite-lithiophilite, graftonite-beusite, and triplite-zwieselite series : first results and implications for pegmatite petrogenesis. Can. Mineral. 52: 321-335.

Rossi, P., Andrade, G.F.; Gaspar, J.C. 1996. The Peixe (Tocantis, Brazil) Mesoproterozoic corundumbearing syenite pegmatite complex: age, considerations on its origin and regional significance. In: SBG, Congresso Brasileiro de Geologia, anais, 39, 6: 426-428.

Scholz, R. 2006. Estudo dos fosfatos do Distrito Pegmatitico de Conselheiro Pena, Minas Gerais. Tese de doutorado, Universidade Federal de Minas Gerais, Belo Horizonte, 120p.

Selway, J.B. 1999. Compositional evolution of tourmaline in granitic pegmatites. $\mathrm{PhD}$ thesis, University of Manitoba, Winnipeg, 363p.

Selway, J.B., Černý, P., Hawthorne, F.C. 2000. The Tanco pegmatite at Bernic Lake , Manitoba . XIV . Internal tourmaline. The Canadian Mineral. 38: 877-891. 
Soares, D.R., Beurlen, H., Barreto, S.B., da Silva, M.R.R., Ferreira, A.C.M. 2008. Compositional variation of tourmaline group minerals in the Borborema Pegmatitic Province, Northeastern Brazil. The Canadian Mineral. 46: 1097-1115.

Sparrenberger, I. \& Tassinari, C.C.G. 1999. Subprovíncia do Rio Paranã (GO): um exemplo de aplicação dos métodos de datação U-Pb e Pb-Pb em cassiterita. Rev. Bras. Geoc. 29(3): 405-414.

Tindle, A.G., Selway, J.B., Breaks, F.W. 2005. Liddicoatite and associated species from the McCombe spodumene-subtype rare-element granitic pegmatite, northwestern Ontario, Canada. The Canadian Mineral. 43: 769-793.

Tischendorf, G. 1997. On Li-bearing micas: estimating Li from electron microprobe analyses and an improved diagram for graphical representation. Mineralogical Magazine. 61: 809-834.

Tkachev, A.V., 2011. Evolution of metallogeny of granitic pegmatites associated with orogens throughout geological time. Geological Society, London, Special Publications, 350(1): 7-23.

Trueman, D. L. and Černý, P., 1982. Exploration for rare-metal granitic pegmatites In: Min. Assoc. Canada, Short Course Handbook, 8: 463-493.

Viana, R.R., Battilani, G.A., Queiroz, H.A., Vogado, M.W., Prado, R.J. 2009. Mineralogy of the Monte Santo alkaline pegmatites with particular reference to cancrinite mineral. Estudos Geológicos UFPE, 19(2): 357-362.

Whitworth, M.P. \& Feely, M. 1994. The compositional range of magmatic Mn-garnets in the Galway granite, Connemara, Ireland. Mineralogical Magazine. 58: 163-168.

Wise, M.A. \& Brown, C.D. 2010. Mineral chemistry, petrology and geochemistry of the Sebago granitepegmatite system, southern Maine, USA. Journal of Geoscience. 55: 3-26.

Zhang, A.C., Zhang, H., Wang, R.C., Hu, H., Chen, X.M. 2004. Ocurrences of foitite and rossmanite from the Koktokay no. 3 granitic pegmatite dyke, Altai, northwestern China: a record for hydrothermal fluids. The Canadian Mineral. 42: 873-882. 
ANEXOS 
Ficha de descrição geral de pegmatitos

\begin{tabular}{|c|c|c|c|c|c|c|}
\hline & Forma & $\begin{array}{l}\text { Direção } \\
\text { da } \\
\text { intrusão }\end{array}$ & $\begin{array}{l}\text { Mergulho } \\
\text { da intrusão }\end{array}$ & $\begin{array}{l}\text { Zonação } \\
\text { (sim/não) }\end{array}$ & $\begin{array}{c}\text { Zonas } \\
\text { observadas } \\
\text { insitu }\end{array}$ & Encaixante \\
\hline "16" & & & & $\begin{array}{c}\text { Não } \\
\text { (homogêneo) }\end{array}$ & & $\begin{array}{c}\text { Grupo Serra da } \\
\text { Mesa* }^{*}\end{array}$ \\
\hline \multicolumn{7}{|c|}{ Pegmatitos explorados para berilo } \\
\hline São Júlio & & NE-SW & & Sim & ZM & $\begin{array}{l}\text { Mica xisto } \\
\text { alterado }\end{array}$ \\
\hline Pichorra & & & & Sim & & $\begin{array}{c}\text { Grupo Serra da } \\
\text { Mesa* }\end{array}$ \\
\hline Onça & & & & Sim & ZM & Aurumina* \\
\hline Fazenda & & & & Sim & & Ticunzal* \\
\hline Mesquita & & & & & & \\
\hline \multicolumn{7}{|c|}{ Pegmatitos explorados para turmalina } \\
\hline Jóia da Mata & & & & Sim & ZM & $\begin{array}{l}\text { Mica xisto } \\
\text { alterado }\end{array}$ \\
\hline "4" & & & & Sim & & $\begin{array}{c}\text { Grupo Serra da } \\
\text { Mesa* }^{*}\end{array}$ \\
\hline$" 5 "$ & & & & Sim & & $\begin{array}{c}\text { Grupo Serra da } \\
\text { Mesa* }\end{array}$ \\
\hline "6" & & & & Sim & & $\begin{array}{c}\text { Grupo Serra da } \\
\text { Mesa* }^{*}\end{array}$ \\
\hline $\begin{array}{l}\text { Córrego das } \\
\text { Pedras }\end{array}$ & & & & Sim & & Grupo Serra da \\
\hline Berilão & & & & Sim & $\mathrm{ZM}, \mathrm{N}$ & $\begin{array}{c}\text { Grupo Serra da } \\
\text { Mesa* }\end{array}$ \\
\hline Marta Rocha & & & & Sim & & $\begin{array}{c}\text { Grupo Serra da } \\
\text { Mesa* }\end{array}$ \\
\hline Índio & & NE-SW & & Sim & ZM & Calcissilicática \\
\hline Zé do Fole & & NE-SW & $\begin{array}{c}\text { Alto } \\
\text { ângulo } \\
\left( \pm 70^{\circ}\right)\end{array}$ & Sim & ZM, ZI & Calcissilicática \\
\hline Boanerges & & NE-SW & & Sim & ZM & Calcissilicática \\
\hline Marimbondo & Tabular & NE-SW & & Sim & $\mathrm{ZM}$ & $\begin{array}{c}\text { Grupo Serra da } \\
\text { Mesa* }\end{array}$ \\
\hline Marimbondinho & & NE-SW & $\begin{array}{l}\text { Alto } \\
\text { ângulo }\end{array}$ & Sim & $\mathrm{ZM}$ & Mica xisto \\
\hline
\end{tabular}

*contato não foi observado, nem afloramentos muito próximos (10-20 metros do pegmatito). A formação indicada é dada com base no mapa geológico da região.

A zonação é inferida com base nas amostras de rejeito

Zonas in situ: ZM: zona de muro, N: núcleo de quartzo maciço, ZI: zona intermediária com grandes cristais de KF, minerais litiníferos e quartzo. 
MUSCOVITAS E TRILITIONITAS 


\begin{tabular}{|c|c|c|c|c|c|c|c|}
\hline & $\begin{array}{c}\text { Hma01 } \\
\text { A2 }\end{array}$ & $\begin{array}{c}\mathrm{Hma} 01 \\
\mathrm{~A} 3\end{array}$ & $\begin{array}{c}\mathrm{Hma01} 1 \\
\mathrm{~A} 4\end{array}$ & $\begin{array}{c}\mathrm{Hma} 01 \\
\mathrm{~A} 5\end{array}$ & $\mathrm{Hmb} 01 \mathrm{C}$ & Hmb01B & Hma01B1 \\
\hline $\mathrm{SiO}_{2}$ & 46.99 & 47.47 & 47.08 & 46.79 & 47.50 & 48.05 & 48.17 \\
\hline $\mathrm{TiO}_{2}$ & 0.06 & 0.01 & 0.02 & 0.04 & 0.04 & 0.00 & 0.09 \\
\hline $\mathrm{Al}_{2} \mathrm{O}_{3}$ & 32.76 & 32.18 & 32.60 & 32.97 & 34.41 & 34.29 & 34.11 \\
\hline $\mathrm{FeO}_{\text {Total }}$ & 1.87 & 1.96 & 1.70 & 1.78 & 1.61 & 1.08 & 1.93 \\
\hline $\mathrm{MnO}$ & 0.16 & 0.24 & 0.22 & 0.27 & 0.06 & 0.28 & 0.10 \\
\hline $\mathrm{MgO}$ & 0.08 & 0.09 & 0.07 & 0.07 & 0.24 & 0.06 & 0.18 \\
\hline $\mathrm{CaO}$ & 0.02 & 0.00 & 0.01 & 0.00 & 0.02 & 0.01 & 0.00 \\
\hline $\mathrm{Na}_{2} \mathrm{O}$ & 0.70 & 0.67 & 0.68 & 0.72 & 0.85 & 0.55 & 0.57 \\
\hline $\mathrm{K}_{2} \mathrm{O}$ & 10.39 & 10.35 & 10.45 & 10.13 & 10.40 & 10.44 & 10.72 \\
\hline $\mathrm{SrO}$ & 0.08 & 0.00 & 0.02 & 0.00 & 0.00 & 0.00 & 0.00 \\
\hline $\mathrm{BaO}$ & 0.03 & 0.07 & 0.00 & 0.00 & 0.06 & 0.00 & 0.00 \\
\hline $\mathrm{Rb}_{2} \mathrm{O}$ & 0.33 & 0.30 & 0.48 & 0.35 & 0.29 & 0.37 & 0.26 \\
\hline $\mathrm{Cs}_{2} \mathrm{O}$ & 0.00 & 0.11 & 0.02 & 0.08 & 0.00 & 0.23 & 0.08 \\
\hline $\mathrm{ZnO}$ & 0.06 & 0.10 & 0.02 & 0.00 & 0.00 & 0.06 & 0.07 \\
\hline F & 1.26 & 1.25 & 1.26 & 1.20 & 0.74 & 0.42 & 0.68 \\
\hline $\mathrm{Li}_{2} \mathrm{O}$ calc. & 0.32 & 0.31 & 0.32 & 0.30 & 0.15 & 0.05 & 0.14 \\
\hline $\mathrm{H}_{2} \mathrm{O}$ calc. & 3.82 & 3.82 & 3.81 & 3.84 & 4.16 & 4.31 & 4.22 \\
\hline $\mathrm{O}=\mathrm{F}$ & 0.53 & 0.53 & 0.53 & 0.51 & 0.31 & 0.18 & 0.29 \\
\hline Total & 98.37 & 98.41 & 98.22 & 98.03 & 100.20 & 100.02 & 101.02 \\
\hline \multicolumn{8}{|c|}{ Fórmula calculada na base de 22 oxigênios } \\
\hline $\mathrm{Si}$ & 6.383 & 6.449 & 6.406 & 6.368 & 6.313 & 6.388 & 6.363 \\
\hline $\mathrm{Al}$ iv & 1.617 & 1.551 & 1.594 & 1.632 & 1.687 & 1.612 & 1.637 \\
\hline $\mathrm{Al}$ vi & 3.628 & 3.603 & 3.634 & 3.657 & 3.702 & 3.762 & 3.673 \\
\hline $\mathrm{Ti}$ & 0.006 & 0.001 & 0.002 & 0.005 & 0.004 & 0.000 & 0.009 \\
\hline $\mathrm{Fe}$ & 0.213 & 0.223 & 0.193 & 0.203 & 0.179 & 0.120 & 0.213 \\
\hline $\mathrm{Mn}$ & 0.018 & 0.027 & 0.026 & 0.031 & 0.007 & 0.031 & 0.011 \\
\hline $\mathrm{Mg}$ & 0.015 & 0.017 & 0.014 & 0.014 & 0.047 & 0.011 & 0.036 \\
\hline $\mathrm{Zn}$ & 0.006 & 0.010 & 0.002 & 0.000 & 0.000 & 0.006 & 0.007 \\
\hline $\mathrm{Li}$ & 0.172 & 0.172 & 0.173 & 0.163 & 0.082 & 0.029 & 0.072 \\
\hline $\mathrm{Ca}$ & 0.003 & 0.000 & 0.002 & 0.000 & 0.003 & 0.001 & 0.000 \\
\hline $\mathrm{Na}$ & 0.184 & 0.176 & 0.179 & 0.189 & 0.218 & 0.141 & 0.145 \\
\hline $\mathrm{K}$ & 1.800 & 1.793 & 1.814 & 1.758 & 1.763 & 1.770 & 1.806 \\
\hline $\mathrm{Sr}$ & 0.006 & 0.000 & 0.002 & 0.000 & 0.000 & 0.000 & 0.000 \\
\hline $\mathrm{Ba}$ & 0.001 & 0.004 & 0.000 & 0.000 & 0.003 & 0.000 & 0.000 \\
\hline $\mathrm{Rb}$ & 0.029 & 0.026 & 0.042 & 0.031 & 0.025 & 0.032 & 0.022 \\
\hline Cs & 0.000 & 0.006 & 0.001 & 0.004 & 0.000 & 0.013 & 0.005 \\
\hline $\mathrm{OH}$ & 3.460 & 3.461 & 3.457 & 3.483 & 3.689 & 3.825 & 3.717 \\
\hline $\mathrm{F}$ & 0.540 & 0.539 & 0.543 & 0.517 & 0.311 & 0.175 & 0.283 \\
\hline
\end{tabular}




\begin{tabular}{|c|c|c|c|c|c|c|c|}
\hline & Hma01B2 & $\mathrm{Hmr01A}$ & $\mathrm{Hmr01B}$ & $\mathrm{Hmb01E}$ & $\mathrm{Hmr01F}$ & $\mathrm{Hmr01G}$ & $\mathrm{Hmr03C1}$ \\
\hline $\mathrm{SiO}_{2}$ & 48.42 & 50.41 & 50.99 & 45.30 & 52.05 & 50.88 & 52.59 \\
\hline $\mathrm{TiO}_{2}$ & 0.06 & 0.00 & 0.01 & 0.00 & 0.00 & 0.00 & 0.00 \\
\hline $\mathrm{Al}_{2} \mathrm{O}_{3}$ & 34.47 & 24.64 & 23.93 & 33.56 & 22.68 & 25.07 & 21.89 \\
\hline $\mathrm{FeO}_{\text {Total }}$ & 1.85 & 0.06 & 0.04 & 0.02 & 0.07 & 0.07 & 0.00 \\
\hline $\mathrm{MnO}$ & 0.06 & 0.23 & 0.26 & 0.01 & 0.24 & 0.23 & 0.77 \\
\hline $\mathrm{MgO}$ & 0.13 & 0.00 & 0.01 & 0.00 & 0.03 & 0.01 & 0.02 \\
\hline $\mathrm{CaO}$ & 0.00 & 0.04 & 0.00 & 0.04 & 0.05 & 0.11 & 0.00 \\
\hline $\mathrm{Na}_{2} \mathrm{O}$ & 0.55 & 0.42 & 0.24 & 0.58 & 0.37 & 0.41 & 0.33 \\
\hline $\mathrm{K}_{2} \mathrm{O}$ & 10.54 & 11.09 & 11.27 & 11.32 & 11.02 & 10.95 & 11.21 \\
\hline $\mathrm{SrO}$ & 0.02 & 0.00 & 0.00 & 0.03 & 0.00 & 0.01 & \\
\hline $\mathrm{BaO}$ & 0.05 & 0.00 & 0.02 & 0.00 & 0.00 & 0.00 & 0.02 \\
\hline $\mathrm{Rb}_{2} \mathrm{O}$ & 0.12 & 0.59 & 0.73 & 0.41 & 0.75 & 0.66 & 0.66 \\
\hline $\mathrm{Cs}_{2} \mathrm{O}$ & 0.00 & 0.45 & 0.23 & 0.05 & 0.56 & 0.24 & 0.32 \\
\hline $\mathrm{ZnO}$ & 0.06 & 0.00 & 0.14 & 0.00 & 0.13 & 0.05 & \\
\hline $\mathrm{F}$ & 0.79 & 7.22 & 7.40 & 1.78 & 7.96 & 6.00 & 9.21 \\
\hline $\mathrm{Li}_{2} \mathrm{O}$ calc. & 0.17 & 4.92 & 5.08 & 3.45 & 5.39 & 5.05 & 5.54 \\
\hline $\mathrm{H}_{2} \mathrm{O}$ calc. & 4.19 & 1.00 & 0.92 & 3.65 & 0.68 & 1.63 & 0.09 \\
\hline $\mathrm{O}=\mathrm{F}$ & 0.33 & 3.04 & 3.12 & 0.75 & 3.35 & 2.53 & 3.88 \\
\hline Total & 101.14 & 98.01 & 98.15 & 99.45 & 98.63 & 98.85 & 98.78 \\
\hline \multicolumn{8}{|c|}{ Fórmula calculada na base de 22 oxigênios } \\
\hline $\mathrm{Si}$ & 6.365 & 6.833 & 6.899 & 6.045 & 7.015 & 6.812 & 7.077 \\
\hline Al iv & 1.635 & 1.167 & 1.101 & 1.955 & 0.985 & 1.188 & 0.923 \\
\hline $\mathrm{Al}$ vi & 3.706 & 2.768 & 2.715 & 3.323 & 2.617 & 2.769 & 2.550 \\
\hline $\mathrm{Ti}$ & 0.005 & 0.000 & 0.001 & 0.000 & 0.000 & 0.000 & 0.000 \\
\hline $\mathrm{Fe}$ & 0.203 & 0.007 & 0.004 & 0.002 & 0.008 & 0.008 & 0.000 \\
\hline $\mathrm{Mn}$ & 0.006 & 0.026 & 0.029 & 0.001 & 0.028 & 0.026 & 0.088 \\
\hline $\mathrm{Mg}$ & 0.026 & 0.000 & 0.003 & 0.000 & 0.006 & 0.002 & 0.004 \\
\hline $\mathrm{Zn}$ & 0.006 & 0.000 & 0.014 & 0.000 & 0.013 & 0.005 & 0.000 \\
\hline $\mathrm{Li}$ & 0.089 & 2.680 & 2.766 & 1.851 & 2.920 & 2.719 & 2.999 \\
\hline $\mathrm{Ca}$ & 0.000 & 0.006 & 0.000 & 0.005 & 0.007 & 0.015 & 0.000 \\
\hline $\mathrm{Na}$ & 0.140 & 0.110 & 0.063 & 0.150 & 0.097 & 0.107 & 0.085 \\
\hline $\mathrm{K}$ & 1.767 & 1.917 & 1.944 & 1.927 & 1.895 & 1.869 & 1.924 \\
\hline $\mathrm{Sr}$ & 0.001 & 0.000 & 0.000 & 0.002 & 0.000 & 0.001 & 0.000 \\
\hline $\mathrm{Ba}$ & 0.003 & 0.000 & 0.001 & 0.000 & 0.000 & 0.000 & 0.001 \\
\hline $\mathrm{Rb}$ & 0.010 & 0.051 & 0.063 & 0.035 & 0.065 & 0.057 & 0.057 \\
\hline $\mathrm{Cs}$ & 0.000 & 0.026 & 0.013 & 0.003 & 0.032 & 0.014 & 0.019 \\
\hline $\mathrm{OH}$ & 3.673 & 0.904 & 0.833 & 3.247 & 0.608 & 1.458 & 0.080 \\
\hline $\mathrm{F}$ & 0.327 & 3.096 & 3.167 & 0.753 & 3.392 & 2.542 & 3.920 \\
\hline
\end{tabular}




\begin{tabular}{|c|c|c|c|c|c|c|c|}
\hline & $\mathrm{HmrO3C2}$ & $\mathrm{Hmr03C3}$ & $\mathrm{Hmr03C4}$ & Hmr03D1 & $\mathrm{Hmr03D2}$ & Hmr03D3 & Hmr03E1 \\
\hline $\mathrm{SiO}_{2}$ & 51.60 & 53.15 & 51.58 & 50.46 & 50.19 & 50.18 & 54.24 \\
\hline $\mathrm{TiO}_{2}$ & 0.00 & 0.00 & 0.00 & 0.02 & 0.03 & 0.00 & 0.01 \\
\hline $\mathrm{Al}_{2} \mathrm{O}_{3}$ & 23.29 & 22.06 & 23.82 & 23.26 & 24.68 & 25.51 & 21.48 \\
\hline $\mathrm{FeO}_{\text {Total }}$ & 0.00 & 0.09 & 0.00 & 0.00 & 0.03 & 0.02 & 0.00 \\
\hline $\mathrm{MnO}$ & 0.72 & 0.79 & 0.84 & 0.67 & 0.84 & 0.79 & 0.76 \\
\hline $\mathrm{MgO}$ & 0.00 & 0.00 & 0.00 & 0.10 & 0.00 & 0.05 & 0.00 \\
\hline $\mathrm{CaO}$ & 0.01 & 0.00 & 0.02 & 0.06 & 0.00 & 0.05 & 0.00 \\
\hline $\mathrm{Na}_{2} \mathrm{O}$ & 0.14 & 0.23 & 0.32 & 0.34 & 0.39 & 0.52 & 0.21 \\
\hline $\mathrm{K}_{2} \mathrm{O}$ & 11.54 & 11.42 & 11.56 & 11.41 & 11.34 & 11.11 & 11.50 \\
\hline \multicolumn{8}{|l|}{$\mathrm{SrO}$} \\
\hline $\mathrm{BaO}$ & 0.00 & 0.11 & 0.09 & 0.02 & 0.00 & 0.00 & 0.00 \\
\hline $\mathrm{Rb}_{2} \mathrm{O}$ & 0.66 & 0.58 & 0.56 & 0.59 & 0.47 & 0.49 & 0.54 \\
\hline $\mathrm{Cs}_{2} \mathrm{O}$ & 0.15 & 0.18 & 0.15 & 0.33 & 0.08 & 0.02 & 0.15 \\
\hline \multicolumn{8}{|l|}{$\mathrm{ZnO}$} \\
\hline $\mathrm{F}$ & 7.69 & 8.69 & 7.74 & 6.68 & 7.44 & 7.02 & 8.74 \\
\hline $\mathrm{Li}_{2} \mathrm{O}$ calc. & 5.26 & 5.70 & 5.25 & 4.93 & 4.85 & 4.85 & 6.02 \\
\hline $\mathrm{H}_{2} \mathrm{O}$ calc. & 0.81 & 0.39 & 0.81 & 1.21 & 0.90 & 1.14 & 0.40 \\
\hline $\mathrm{O}=\mathrm{F}$ & 3.24 & 3.66 & 3.26 & 2.81 & 3.13 & 2.96 & 3.68 \\
\hline Total & 98.62 & 99.74 & 99.51 & 97.27 & 98.10 & 98.79 & 100.37 \\
\hline \multicolumn{8}{|c|}{ Fórmula calculada na base de 22 oxigênios } \\
\hline $\mathrm{Si}$ & 6.952 & 7.074 & 6.898 & 6.911 & 6.802 & 6.740 & 7.148 \\
\hline $\mathrm{Al}$ iv & 1.048 & 0.926 & 1.102 & 1.089 & 1.198 & 1.260 & 0.852 \\
\hline Al vi & 2.649 & 2.535 & 2.653 & 2.665 & 2.745 & 2.779 & 2.483 \\
\hline $\mathrm{Ti}$ & 0.000 & 0.000 & 0.000 & 0.002 & 0.003 & 0.000 & 0.001 \\
\hline $\mathrm{Fe}$ & 0.000 & 0.010 & 0.000 & 0.000 & 0.003 & 0.002 & 0.000 \\
\hline $\mathrm{Mn}$ & 0.082 & 0.089 & 0.095 & 0.077 & 0.096 & 0.090 & 0.084 \\
\hline $\mathrm{Mg}$ & 0.000 & 0.000 & 0.000 & 0.020 & 0.000 & 0.010 & 0.000 \\
\hline $\mathrm{Zn}$ & 0.000 & 0.000 & 0.000 & 0.000 & 0.000 & 0.000 & 0.000 \\
\hline $\mathrm{Li}$ & 2.849 & 3.052 & 2.825 & 2.716 & 2.645 & 2.620 & 3.188 \\
\hline $\mathrm{Ca}$ & 0.002 & 0.000 & 0.003 & 0.009 & 0.000 & 0.007 & 0.000 \\
\hline $\mathrm{Na}$ & 0.037 & 0.060 & 0.084 & 0.091 & 0.103 & 0.135 & 0.054 \\
\hline $\mathrm{K}$ & 1.982 & 1.939 & 1.972 & 1.993 & 1.960 & 1.904 & 1.933 \\
\hline $\mathrm{Sr}$ & 0.000 & 0.000 & 0.000 & 0.000 & 0.000 & 0.000 & 0.000 \\
\hline $\mathrm{Ba}$ & 0.000 & 0.006 & 0.005 & 0.001 & 0.000 & 0.000 & 0.000 \\
\hline $\mathrm{Rb}$ & 0.057 & 0.050 & 0.048 & 0.052 & 0.041 & 0.042 & 0.046 \\
\hline $\mathrm{Cs}$ & 0.009 & 0.010 & 0.009 & 0.019 & 0.005 & 0.001 & 0.009 \\
\hline $\mathrm{OH}$ & 0.725 & 0.343 & 0.727 & 1.108 & 0.813 & 1.018 & 0.356 \\
\hline $\mathrm{F}$ & 3.275 & 3.657 & 3.273 & 2.892 & 3.187 & 2.982 & 3.644 \\
\hline
\end{tabular}




\begin{tabular}{|c|c|c|c|c|c|c|c|}
\hline & Hmr03E2 & Hmr03E3 & $\mathrm{Hmr03C1}$ & $\mathrm{Hmr03C2}$ & $\mathrm{HmrO3C3}$ & $\mathrm{HmrO3C4}$ & $\mathrm{Hmr03D2}$ \\
\hline $\mathrm{SiO}_{2}$ & 52.33 & 52.22 & 52.59 & 51.60 & 53.15 & 51.58 & 50.19 \\
\hline $\mathrm{TiO}_{2}$ & 0.00 & 0.03 & 0.00 & 0.00 & 0.00 & 0.00 & 0.03 \\
\hline $\mathrm{Al}_{2} \mathrm{O}_{3}$ & 24.38 & 22.53 & 21.89 & 23.29 & 22.06 & 23.82 & 24.68 \\
\hline $\mathrm{FeO}_{\text {Total }}$ & 0.04 & 0.08 & 0.00 & 0.00 & 0.09 & 0.00 & 0.03 \\
\hline $\mathrm{MnO}$ & 0.40 & 0.94 & 0.77 & 0.72 & 0.79 & 0.84 & 0.84 \\
\hline $\mathrm{MgO}$ & 0.26 & 0.00 & 0.02 & 0.00 & 0.00 & 0.00 & 0.00 \\
\hline $\mathrm{CaO}$ & 0.12 & 0.00 & 0.00 & 0.01 & 0.00 & 0.02 & 0.00 \\
\hline $\mathrm{Na}_{2} \mathrm{O}$ & 0.19 & 0.31 & 0.33 & 0.14 & 0.23 & 0.32 & 0.39 \\
\hline $\mathrm{K}_{2} \mathrm{O}$ & 11.16 & 11.56 & 11.21 & 11.54 & 11.42 & 11.56 & 11.34 \\
\hline \multicolumn{8}{|l|}{$\mathrm{SrO}$} \\
\hline $\mathrm{BaO}$ & 0.08 & 0.00 & 0.02 & 0.00 & 0.11 & 0.09 & 0.00 \\
\hline $\mathrm{Rb}_{2} \mathrm{O}$ & 0.39 & 0.64 & 0.66 & 0.66 & 0.58 & 0.56 & 0.47 \\
\hline $\mathrm{Cs}_{2} \mathrm{O}$ & 0.16 & 0.06 & 0.32 & 0.15 & 0.18 & 0.15 & 0.08 \\
\hline \multicolumn{8}{|l|}{$\mathrm{ZnO}$} \\
\hline $\mathrm{F}$ & 5.93 & 8.51 & 9.21 & 7.69 & 8.69 & 7.74 & 7.44 \\
\hline $\mathrm{Li}_{2} \mathrm{O}$ calc. & 5.47 & 5.43 & 5.54 & 5.26 & 5.70 & 5.25 & 4.85 \\
\hline $\mathrm{H}_{2} \mathrm{O}$ calc. & 1.74 & 0.44 & 0.09 & 0.81 & 0.39 & 0.81 & 0.90 \\
\hline $\mathrm{O}=\mathrm{F}$ & 2.50 & 3.58 & 3.88 & 3.24 & 3.66 & 3.26 & 3.13 \\
\hline Total & 100.14 & 99.16 & 98.78 & 98.62 & 99.74 & 99.51 & 98.10 \\
\hline \multicolumn{8}{|c|}{ Fórmula calculada na base de 22 oxigênios } \\
\hline $\mathrm{Si}$ & 6.889 & 7.005 & 7.077 & 6.952 & 7.074 & 6.898 & 6.802 \\
\hline Al iv & 1.111 & 0.995 & 0.923 & 1.048 & 0.926 & 1.102 & 1.198 \\
\hline $\mathrm{Al}$ vi & 2.671 & 2.568 & 2.550 & 2.649 & 2.535 & 2.653 & 2.745 \\
\hline $\mathrm{Ti}$ & 0.000 & 0.003 & 0.000 & 0.000 & 0.000 & 0.000 & 0.003 \\
\hline $\mathrm{Fe}$ & 0.004 & 0.009 & 0.000 & 0.000 & 0.010 & 0.000 & 0.003 \\
\hline $\mathrm{Mn}$ & 0.045 & 0.106 & 0.088 & 0.082 & 0.089 & 0.095 & 0.096 \\
\hline $\mathrm{Mg}$ & 0.051 & 0.000 & 0.004 & 0.000 & 0.000 & 0.000 & 0.000 \\
\hline $\mathrm{Zn}$ & 0.000 & 0.000 & 0.000 & 0.000 & 0.000 & 0.000 & 0.000 \\
\hline $\mathrm{Li}$ & 2.895 & 2.932 & 2.999 & 2.849 & 3.052 & 2.825 & 2.645 \\
\hline $\mathrm{Ca}$ & 0.017 & 0.000 & 0.000 & 0.002 & 0.000 & 0.003 & 0.000 \\
\hline $\mathrm{Na}$ & 0.049 & 0.079 & 0.085 & 0.037 & 0.060 & 0.084 & 0.103 \\
\hline $\mathrm{K}$ & 1.873 & 1.978 & 1.924 & 1.982 & 1.939 & 1.972 & 1.960 \\
\hline $\mathrm{Sr}$ & 0.000 & 0.000 & 0.000 & 0.000 & 0.000 & 0.000 & 0.000 \\
\hline $\mathrm{Ba}$ & 0.004 & 0.000 & 0.001 & 0.000 & 0.006 & 0.005 & 0.000 \\
\hline $\mathrm{Rb}$ & 0.033 & 0.055 & 0.057 & 0.057 & 0.050 & 0.048 & 0.041 \\
\hline $\mathrm{Cs}$ & 0.009 & 0.003 & 0.019 & 0.009 & 0.010 & 0.009 & 0.005 \\
\hline $\mathrm{OH}$ & 1.531 & 0.390 & 0.080 & 0.725 & 0.343 & 0.727 & 0.813 \\
\hline $\mathrm{F}$ & 2.469 & 3.610 & 3.920 & 3.275 & 3.657 & 3.273 & 3.187 \\
\hline
\end{tabular}




\begin{tabular}{|c|c|c|c|c|c|c|c|}
\hline & Hmr03D3 & Hmr03E1 & Hmr03E2 & Hmr03E3 & $\mathrm{HmrO3B}$ & $\mathrm{Hmb05H2}$ & $\mathrm{Hmr05E}$ \\
\hline $\mathrm{SiO}_{2}$ & 50.18 & 54.24 & 52.33 & 52.22 & 53.49 & 44.66 & 51.24 \\
\hline $\mathrm{TiO}_{2}$ & 0.00 & 0.01 & 0.00 & 0.03 & 0.00 & 0.06 & 0.00 \\
\hline $\mathrm{Al}_{2} \mathrm{O}_{3}$ & 25.51 & 21.48 & 24.38 & 22.53 & 23.82 & 32.74 & 26.27 \\
\hline $\mathrm{FeO}_{\text {Total }}$ & 0.02 & 0.00 & 0.04 & 0.08 & 0.03 & 2.43 & 0.12 \\
\hline $\mathrm{MnO}$ & 0.79 & 0.76 & 0.40 & 0.94 & 0.26 & 0.33 & 0.76 \\
\hline $\mathrm{MgO}$ & 0.05 & 0.00 & 0.26 & 0.00 & 0.00 & 0.13 & 0.00 \\
\hline $\mathrm{CaO}$ & 0.05 & 0.00 & 0.12 & 0.00 & 0.01 & 0.03 & 0.01 \\
\hline $\mathrm{Na}_{2} \mathrm{O}$ & 0.52 & 0.21 & 0.19 & 0.31 & 0.29 & 0.66 & 0.37 \\
\hline $\mathrm{K}_{2} \mathrm{O}$ & 11.11 & 11.50 & 11.16 & 11.56 & 11.05 & 10.01 & 11.21 \\
\hline $\mathrm{SrO}$ & & & & & 0.05 & & \\
\hline $\mathrm{BaO}$ & 0.00 & 0.00 & 0.08 & 0.00 & 0.00 & 0.00 & 0.00 \\
\hline $\mathrm{Rb}_{2} \mathrm{O}$ & 0.49 & 0.54 & 0.39 & 0.64 & 0.80 & 0.23 & 0.75 \\
\hline $\mathrm{Cs}_{2} \mathrm{O}$ & 0.02 & 0.15 & 0.16 & 0.06 & 0.13 & 0.06 & 0.17 \\
\hline $\mathrm{ZnO}$ & & & & & 0.00 & & \\
\hline $\mathrm{F}$ & 7.02 & 8.74 & 5.93 & 8.51 & 7.50 & 0.23 & 6.24 \\
\hline $\mathrm{Li}_{2} \mathrm{O}$ calc. & 4.85 & 6.02 & 5.47 & 5.43 & 5.80 & 0.00 & 5.15 \\
\hline $\mathrm{H}_{2} \mathrm{O}$ calc. & 1.14 & 0.40 & 1.74 & 0.44 & 1.04 & 4.17 & 1.61 \\
\hline $\mathrm{O}=\mathrm{F}$ & 2.96 & 3.68 & 2.50 & 3.58 & 3.16 & 0.10 & 2.63 \\
\hline Total & 98.79 & 100.37 & 100.14 & 99.16 & 101.10 & 95.66 & 101.28 \\
\hline \multicolumn{8}{|c|}{ Fórmula calculada na base de 22 oxigênios } \\
\hline $\mathrm{Si}$ & 6.740 & 7.148 & 6.889 & 7.005 & 6.977 & 6.260 & 6.717 \\
\hline $\mathrm{Al}$ iv & 1.260 & 0.852 & 1.111 & 0.995 & 1.023 & 1.740 & 1.283 \\
\hline Al vi & 2.779 & 2.483 & 2.671 & 2.568 & 2.640 & 3.669 & 2.776 \\
\hline $\mathrm{Ti}$ & 0.000 & 0.001 & 0.000 & 0.003 & 0.000 & 0.006 & 0.000 \\
\hline $\mathrm{Fe}$ & 0.002 & 0.000 & 0.004 & 0.009 & 0.003 & 0.285 & 0.013 \\
\hline $\mathrm{Mn}$ & 0.090 & 0.084 & 0.045 & 0.106 & 0.029 & 0.039 & 0.084 \\
\hline $\mathrm{Mg}$ & 0.010 & 0.000 & 0.051 & 0.000 & 0.000 & 0.028 & 0.000 \\
\hline $\mathrm{Zn}$ & 0.000 & 0.000 & 0.000 & 0.000 & 0.000 & 0.000 & 0.000 \\
\hline $\mathrm{Li}$ & 2.620 & 3.188 & 2.895 & 2.932 & 3.042 & 0.000 & 2.718 \\
\hline $\mathrm{Ca}$ & 0.007 & 0.000 & 0.017 & 0.000 & 0.002 & 0.005 & 0.001 \\
\hline $\mathrm{Na}$ & 0.135 & 0.054 & 0.049 & 0.079 & 0.073 & 0.180 & 0.094 \\
\hline $\mathrm{K}$ & 1.904 & 1.933 & 1.873 & 1.978 & 1.839 & 1.790 & 1.875 \\
\hline $\mathrm{Sr}$ & 0.000 & 0.000 & 0.000 & 0.000 & 0.004 & 0.000 & 0.000 \\
\hline $\mathrm{Ba}$ & 0.000 & 0.000 & 0.004 & 0.000 & 0.000 & 0.000 & 0.000 \\
\hline $\mathrm{Rb}$ & 0.042 & 0.046 & 0.033 & 0.055 & 0.067 & 0.021 & 0.063 \\
\hline $\mathrm{Cs}$ & 0.001 & 0.009 & 0.009 & 0.003 & 0.007 & 0.004 & 0.010 \\
\hline $\mathrm{OH}$ & 1.018 & 0.356 & 1.531 & 0.390 & 0.905 & 3.897 & 1.412 \\
\hline $\mathrm{F}$ & 2.982 & 3.644 & 2.469 & 3.610 & 3.095 & 0.103 & 2.588 \\
\hline
\end{tabular}




\begin{tabular}{|c|c|c|c|c|c|c|c|}
\hline & $\mathrm{Hmr05H}$ & $\mathrm{Hmb05}$ D1 & $\mathrm{Hmb05}$ D2 & $\mathrm{Hmb05}$ D3 & $\mathrm{Hmb05}$ D4 & $\mathrm{Hmr05} \mathrm{A}$ & $\mathrm{Hmb05A}$ \\
\hline $\mathrm{SiO}_{2}$ & 49.69 & 45.88 & 45.88 & 46.06 & 46.20 & 53.34 & 48.05 \\
\hline $\mathrm{TiO}_{2}$ & 0.00 & 0.10 & 0.06 & 0.10 & 0.09 & 0.00 & 0.11 \\
\hline $\mathrm{Al}_{2} \mathrm{O}_{3}$ & 29.01 & 32.41 & 32.72 & 32.75 & 32.93 & 23.74 & 32.85 \\
\hline $\mathrm{FeO}_{\text {Total }}$ & 0.13 & 1.87 & 2.02 & 1.94 & 1.93 & 0.06 & 2.44 \\
\hline $\mathrm{MnO}$ & 0.42 & 0.29 & 0.27 & 0.32 & 0.36 & 0.98 & 0.05 \\
\hline $\mathrm{MgO}$ & 0.04 & 0.06 & 0.04 & 0.07 & 0.06 & 0.00 & 0.15 \\
\hline $\mathrm{CaO}$ & 0.04 & 0.04 & 0.02 & 0.02 & 0.00 & 0.00 & 0.00 \\
\hline $\mathrm{Na}_{2} \mathrm{O}$ & 0.43 & 0.76 & 0.72 & 0.70 & 0.65 & 0.37 & 0.77 \\
\hline $\mathrm{K}_{2} \mathrm{O}$ & 11.01 & 10.54 & 10.46 & 10.51 & 10.38 & 10.94 & 9.59 \\
\hline $\mathrm{SrO}$ & & 0.02 & 0.00 & 0.00 & 0.00 & 0.04 & 0.00 \\
\hline $\mathrm{BaO}$ & 0.01 & 0.00 & 0.00 & 0.00 & 0.05 & 0.04 & 0.04 \\
\hline $\mathrm{Rb}_{2} \mathrm{O}$ & 0.53 & 0.35 & 0.34 & 0.37 & 0.37 & 0.77 & 0.39 \\
\hline $\mathrm{Cs}_{2} \mathrm{O}$ & 0.01 & 0.00 & 0.03 & 0.03 & 0.09 & 0.24 & 0.00 \\
\hline $\mathrm{ZnO}$ & & 0.15 & 0.00 & 0.00 & 0.00 & 0.12 & 0.00 \\
\hline $\mathrm{F}$ & 4.76 & 1.27 & 1.50 & 1.25 & 1.28 & 8.37 & 0.33 \\
\hline $\mathrm{Li}_{2} \mathrm{O}$ calc. & 4.71 & 0.00 & 0.39 & 0.31 & 0.32 & 5.76 & 0.00 \\
\hline $\mathrm{H}_{2} \mathrm{O}$ calc. & 2.33 & 3.73 & 3.65 & 3.78 & 3.78 & 0.63 & 4.30 \\
\hline $\mathrm{O}=\mathrm{F}$ & 2.00 & 0.53 & 0.63 & 0.53 & 0.54 & 3.52 & 0.14 \\
\hline Total & 101.12 & 96.93 & 97.46 & 97.68 & 97.94 & 101.85 & 98.94 \\
\hline \multicolumn{8}{|c|}{ Fórmula calculada na base de 22 oxigênios } \\
\hline $\mathrm{Si}$ & 6.494 & 6.355 & 6.310 & 6.320 & 6.320 & 6.950 & 6.459 \\
\hline Al iv & 1.506 & 1.645 & 1.690 & 1.680 & 1.680 & 1.050 & 1.541 \\
\hline $\mathrm{Al}$ vi & 2.964 & 3.646 & 3.614 & 3.618 & 3.630 & 2.595 & 3.664 \\
\hline $\mathrm{Ti}$ & 0.000 & 0.010 & 0.006 & 0.011 & 0.009 & 0.000 & 0.011 \\
\hline $\mathrm{Fe}$ & 0.015 & 0.217 & 0.232 & 0.223 & 0.221 & 0.006 & 0.274 \\
\hline $\mathrm{Mn}$ & 0.046 & 0.034 & 0.031 & 0.037 & 0.042 & 0.108 & 0.005 \\
\hline $\mathrm{Mg}$ & 0.008 & 0.011 & 0.009 & 0.014 & 0.012 & 0.000 & 0.031 \\
\hline $\mathrm{Zn}$ & 0.000 & 0.015 & 0.000 & 0.000 & 0.000 & 0.011 & 0.000 \\
\hline $\mathrm{Li}$ & 2.476 & 0.000 & 0.216 & 0.173 & 0.178 & 3.017 & 0.000 \\
\hline $\mathrm{Ca}$ & 0.006 & 0.006 & 0.003 & 0.002 & 0.000 & 0.000 & 0.000 \\
\hline $\mathrm{Na}$ & 0.108 & 0.204 & 0.191 & 0.186 & 0.172 & 0.093 & 0.200 \\
\hline $\mathrm{K}$ & 1.836 & 1.861 & 1.835 & 1.840 & 1.811 & 1.817 & 1.645 \\
\hline $\mathrm{Sr}$ & 0.000 & 0.002 & 0.000 & 0.000 & 0.000 & 0.003 & 0.000 \\
\hline $\mathrm{Ba}$ & 0.000 & 0.000 & 0.000 & 0.000 & 0.003 & 0.002 & 0.002 \\
\hline $\mathrm{Rb}$ & 0.045 & 0.031 & 0.030 & 0.033 & 0.033 & 0.064 & 0.034 \\
\hline Cs & 0.001 & 0.000 & 0.002 & 0.002 & 0.005 & 0.013 & 0.000 \\
\hline $\mathrm{OH}$ & 2.033 & 3.444 & 3.348 & 3.458 & 3.446 & 0.551 & 3.859 \\
\hline $\mathrm{F}$ & 1.967 & 0.556 & 0.652 & 0.542 & 0.554 & 3.449 & 0.141 \\
\hline
\end{tabular}




\begin{tabular}{|c|c|c|c|c|c|c|c|}
\hline & $\mathrm{Hmb05B}$ & $\mathrm{Hmb05C}$ & Hmb10A1 & $\mathrm{Hmb} 10 \mathrm{~A} 2$ & $\mathrm{Hmb} 10 \mathrm{~A} 3$ & $\mathrm{Hmb} 10 \mathrm{~A} 4$ & $\mathrm{Hmb10A6}$ \\
\hline $\mathrm{SiO}_{2}$ & 47.75 & 49.32 & 45.54 & 45.30 & 44.84 & 44.30 & 44.87 \\
\hline $\mathrm{TiO}_{2}$ & 0.07 & 0.08 & 0.00 & 0.00 & 0.00 & 0.00 & 0.00 \\
\hline $\mathrm{Al}_{2} \mathrm{O}_{3}$ & 33.33 & 33.14 & 34.91 & 34.79 & 33.71 & 33.81 & 33.98 \\
\hline $\mathrm{FeO}_{\text {Total }}$ & 1.92 & 2.60 & 3.73 & 3.84 & 3.69 & 3.93 & 3.57 \\
\hline $\mathrm{MnO}$ & 0.19 & 0.32 & 0.08 & 0.09 & 0.07 & 0.06 & 0.05 \\
\hline $\mathrm{MgO}$ & 0.11 & 0.11 & 0.38 & 0.32 & 0.33 & 0.34 & 0.25 \\
\hline $\mathrm{CaO}$ & 0.00 & 0.00 & 0.02 & 0.01 & 0.03 & 0.00 & 0.01 \\
\hline $\mathrm{Na}_{2} \mathrm{O}$ & 0.64 & 0.66 & 0.65 & 0.70 & 0.59 & 0.74 & 0.66 \\
\hline $\mathrm{K}_{2} \mathrm{O}$ & 9.72 & 10.16 & 10.37 & 10.45 & 10.57 & 10.22 & 10.26 \\
\hline $\mathrm{SrO}$ & 0.00 & 0.00 & 0.01 & 0.00 & 0.00 & 0.00 & 0.12 \\
\hline $\mathrm{BaO}$ & 0.00 & 0.00 & 0.00 & 0.00 & 0.00 & 0.00 & 0.08 \\
\hline $\mathrm{Rb}_{2} \mathrm{O}$ & 0.31 & 0.28 & & & & & \\
\hline $\mathrm{Cs}_{2} \mathrm{O}$ & 0.00 & 0.01 & 0.00 & 0.00 & 0.00 & 0.00 & 0.03 \\
\hline $\mathrm{ZnO}$ & 0.03 & 0.00 & & & & & \\
\hline $\mathrm{F}$ & 0.08 & 0.40 & 1.60 & 1.65 & 1.55 & 1.69 & 1.61 \\
\hline $\mathrm{Li}_{2} \mathrm{O}$ calc. & 0.00 & 0.05 & 0.42 & 0.44 & 0.41 & 0.45 & 0.42 \\
\hline $\mathrm{H}_{2} \mathrm{O}$ calc. & 4.42 & 4.37 & 3.73 & 3.69 & 3.65 & 3.57 & 3.64 \\
\hline $\mathrm{O}=\mathrm{F}$ & 0.03 & 0.17 & 0.67 & 0.69 & 0.65 & 0.71 & 0.68 \\
\hline Total & 98.52 & 101.32 & 100.77 & 100.58 & 98.78 & 98.38 & 98.87 \\
\hline \multicolumn{8}{|c|}{ Fórmula calculada na base de 22 oxigênios } \\
\hline $\mathrm{Si}$ & 6.430 & 6.487 & 6.083 & 6.073 & 6.124 & 6.078 & 6.117 \\
\hline Al iv & 1.570 & 1.513 & 1.917 & 1.927 & 1.876 & 1.922 & 1.883 \\
\hline $\mathrm{Al}$ vi & 3.718 & 3.624 & 3.581 & 3.570 & 3.551 & 3.546 & 3.578 \\
\hline $\mathrm{Ti}$ & 0.007 & 0.008 & 0.000 & 0.000 & 0.000 & 0.000 & 0.000 \\
\hline $\mathrm{Fe}$ & 0.216 & 0.286 & 0.417 & 0.430 & 0.421 & 0.450 & 0.407 \\
\hline $\mathrm{Mn}$ & 0.022 & 0.036 & 0.009 & 0.010 & 0.008 & 0.007 & 0.006 \\
\hline $\mathrm{Mg}$ & 0.021 & 0.022 & 0.076 & 0.064 & 0.067 & 0.069 & 0.051 \\
\hline $\mathrm{Zn}$ & 0.002 & 0.000 & 0.000 & 0.000 & 0.000 & 0.000 & 0.000 \\
\hline $\mathrm{Li}$ & 0.000 & 0.026 & 0.227 & 0.235 & 0.224 & 0.248 & 0.233 \\
\hline $\mathrm{Ca}$ & 0.000 & 0.000 & 0.003 & 0.001 & 0.004 & 0.000 & 0.001 \\
\hline $\mathrm{Na}$ & 0.168 & 0.168 & 0.168 & 0.182 & 0.157 & 0.196 & 0.174 \\
\hline $\mathrm{K}$ & 1.668 & 1.705 & 1.767 & 1.787 & 1.842 & 1.788 & 1.784 \\
\hline $\mathrm{Sr}$ & 0.000 & 0.000 & 0.000 & 0.000 & 0.000 & 0.000 & 0.009 \\
\hline $\mathrm{Ba}$ & 0.000 & 0.000 & 0.000 & 0.000 & 0.000 & 0.000 & 0.004 \\
\hline $\mathrm{Rb}$ & 0.027 & 0.023 & 0.000 & 0.000 & 0.000 & 0.000 & 0.000 \\
\hline $\mathrm{Cs}$ & 0.000 & 0.001 & 0.000 & 0.000 & 0.000 & 0.000 & 0.002 \\
\hline $\mathrm{OH}$ & 3.966 & 3.833 & 3.323 & 3.303 & 3.330 & 3.268 & 3.307 \\
\hline $\mathrm{F}$ & 0.034 & 0.167 & 0.677 & 0.697 & 0.670 & 0.732 & 0.693 \\
\hline
\end{tabular}




\begin{tabular}{|c|c|c|c|c|c|c|c|}
\hline & $\mathrm{Hmb10A7}$ & $\mathrm{Hmb} 10 \mathrm{~A} 8$ & Hmb10A9 & $\mathrm{Hmb} 10 \mathrm{~A} 10$ & Hmb10B1 & $\mathrm{Hmb} 10 \mathrm{~B} 2$ & Hmb10B3 \\
\hline $\mathrm{SiO}_{2}$ & 45.54 & 45.57 & 44.56 & 45.40 & 45.02 & 45.16 & 45.16 \\
\hline $\mathrm{TiO}_{2}$ & 0.00 & 0.00 & 0.01 & 0.00 & 0.00 & 0.01 & 0.00 \\
\hline $\mathrm{Al}_{2} \mathrm{O}_{3}$ & 34.57 & 34.50 & 34.78 & 34.82 & 33.98 & 33.61 & 33.49 \\
\hline $\mathrm{FeO}_{\text {Total }}$ & 3.85 & 3.63 & 3.20 & 3.67 & 4.53 & 4.17 & 4.37 \\
\hline $\mathrm{MnO}$ & 0.09 & 0.10 & 0.05 & 0.05 & 0.10 & 0.05 & 0.14 \\
\hline $\mathrm{MgO}$ & 0.27 & 0.31 & 0.28 & 0.36 & 0.07 & 0.05 & 0.04 \\
\hline $\mathrm{CaO}$ & 0.00 & 0.01 & 0.02 & 0.02 & 0.00 & 0.00 & 0.03 \\
\hline $\mathrm{Na}_{2} \mathrm{O}$ & 0.56 & 0.65 & 0.83 & 0.71 & 0.70 & 0.60 & 0.51 \\
\hline $\mathrm{K}_{2} \mathrm{O}$ & 10.24 & 10.27 & 10.09 & 10.49 & 10.05 & 10.25 & 10.48 \\
\hline $\mathrm{SrO}$ & 0.00 & 0.00 & 0.00 & 0.04 & 0.02 & 0.04 & 0.00 \\
\hline $\mathrm{BaO}$ & 0.00 & 0.00 & 0.00 & 0.00 & 0.00 & 0.01 & 0.00 \\
\hline \multicolumn{8}{|l|}{$\mathrm{Rb}_{2} \mathrm{O}$} \\
\hline $\mathrm{Cs}_{2} \mathrm{O}$ & 0.00 & 0.06 & 0.03 & 0.00 & 0.00 & 0.02 & 0.00 \\
\hline \multicolumn{8}{|l|}{$\mathrm{ZnO}$} \\
\hline $\mathrm{F}$ & 1.52 & 1.54 & 1.28 & 1.63 & 1.88 & 1.68 & 1.87 \\
\hline $\mathrm{Li}_{2} \mathrm{O}$ calc. & 0.40 & 0.40 & 0.32 & 0.43 & 0.51 & 0.45 & 0.51 \\
\hline $\mathrm{H}_{2} \mathrm{O}$ calc. & 3.74 & 3.73 & 3.80 & 3.71 & 3.53 & 3.60 & 3.52 \\
\hline $\mathrm{O}=\mathrm{F}$ & 0.64 & 0.65 & 0.54 & 0.69 & 0.79 & 0.71 & 0.79 \\
\hline Total & 100.13 & 100.11 & 98.71 & 100.63 & 99.60 & 99.00 & 99.32 \\
\hline \multicolumn{8}{|c|}{ Fórmula calculada na base de 22 oxigênios } \\
\hline $\mathrm{Si}$ & 6.117 & 6.123 & 6.063 & 6.079 & 6.105 & 6.155 & 6.149 \\
\hline $\mathrm{Al}$ iv & 1.883 & 1.877 & 1.937 & 1.921 & 1.895 & 1.845 & 1.851 \\
\hline Al vi & 3.592 & 3.588 & 3.642 & 3.575 & 3.537 & 3.555 & 3.524 \\
\hline $\mathrm{Ti}$ & 0.000 & 0.000 & 0.001 & 0.000 & 0.000 & 0.001 & 0.000 \\
\hline $\mathrm{Fe}$ & 0.432 & 0.408 & 0.364 & 0.411 & 0.514 & 0.476 & 0.498 \\
\hline $\mathrm{Mn}$ & 0.010 & 0.011 & 0.006 & 0.006 & 0.012 & 0.006 & 0.016 \\
\hline $\mathrm{Mg}$ & 0.053 & 0.061 & 0.057 & 0.071 & 0.015 & 0.009 & 0.008 \\
\hline $\mathrm{Zn}$ & 0.000 & 0.000 & 0.000 & 0.000 & 0.000 & 0.000 & 0.000 \\
\hline $\mathrm{Li}$ & 0.214 & 0.218 & 0.176 & 0.232 & 0.279 & 0.245 & 0.277 \\
\hline $\mathrm{Ca}$ & 0.000 & 0.002 & 0.003 & 0.002 & 0.000 & 0.000 & 0.004 \\
\hline $\mathrm{Na}$ & 0.147 & 0.169 & 0.220 & 0.185 & 0.183 & 0.159 & 0.134 \\
\hline $\mathrm{K}$ & 1.755 & 1.760 & 1.752 & 1.791 & 1.739 & 1.783 & 1.819 \\
\hline $\mathrm{Sr}$ & 0.000 & 0.000 & 0.000 & 0.003 & 0.001 & 0.003 & 0.000 \\
\hline $\mathrm{Ba}$ & 0.000 & 0.000 & 0.000 & 0.000 & 0.000 & 0.001 & 0.000 \\
\hline $\mathrm{Rb}$ & 0.000 & 0.000 & 0.000 & 0.000 & 0.000 & 0.000 & 0.000 \\
\hline $\mathrm{Cs}$ & 0.000 & 0.004 & 0.002 & 0.000 & 0.000 & 0.001 & 0.000 \\
\hline $\mathrm{OH}$ & 3.355 & 3.346 & 3.450 & 3.311 & 3.192 & 3.277 & 3.197 \\
\hline $\mathrm{F}$ & 0.645 & 0.654 & 0.550 & 0.689 & 0.808 & 0.723 & 0.803 \\
\hline
\end{tabular}




\begin{tabular}{|c|c|c|c|c|c|c|c|}
\hline & Hmb10B4 & Hmb10B5 & $\mathrm{Hmb10B6}$ & Hmb10B7 & Hmb10B8 & Hmb10B9 & Hmb10B10 \\
\hline $\mathrm{SiO}_{2}$ & 45.08 & 45.16 & 45.47 & 45.21 & 44.81 & 45.18 & 44.68 \\
\hline $\mathrm{TiO}_{2}$ & 0.00 & 0.00 & 0.01 & 0.03 & 0.00 & 0.00 & 0.00 \\
\hline $\mathrm{Al}_{2} \mathrm{O}_{3}$ & 34.08 & 33.80 & 33.73 & 33.81 & 33.81 & 34.25 & 33.27 \\
\hline $\mathrm{FeO}_{\text {Total }}$ & 4.54 & 4.31 & 4.29 & 4.45 & 4.03 & 4.54 & 4.32 \\
\hline $\mathrm{MnO}$ & 0.07 & 0.07 & 0.03 & 0.03 & 0.03 & 0.09 & 0.08 \\
\hline $\mathrm{MgO}$ & 0.07 & 0.05 & 0.08 & 0.05 & 0.10 & 0.03 & 0.06 \\
\hline $\mathrm{CaO}$ & 0.02 & 0.00 & 0.00 & 0.01 & 0.02 & 0.00 & 0.00 \\
\hline $\mathrm{Na}_{2} \mathrm{O}$ & 0.55 & 0.71 & 0.65 & 0.71 & 0.42 & 0.63 & 0.51 \\
\hline $\mathrm{K}_{2} \mathrm{O}$ & 10.35 & 10.37 & 10.37 & 10.20 & 10.33 & 10.19 & 10.20 \\
\hline $\mathrm{SrO}$ & 0.00 & 0.00 & 0.05 & 0.00 & 0.00 & 0.00 & 0.05 \\
\hline $\mathrm{BaO}$ & 0.00 & 0.00 & 0.06 & 0.00 & 0.00 & 0.00 & 0.00 \\
\hline \multicolumn{8}{|l|}{$\mathrm{Rb}_{2} \mathrm{O}$} \\
\hline $\mathrm{Cs}_{2} \mathrm{O}$ & 0.00 & 0.00 & 0.09 & 0.14 & 0.02 & 0.08 & 0.00 \\
\hline \multicolumn{8}{|l|}{$\mathrm{ZnO}$} \\
\hline $\mathrm{F}$ & 1.83 & 1.82 & 1.78 & 1.80 & 1.56 & 1.76 & 1.71 \\
\hline $\mathrm{Li}_{2} \mathrm{O}$ calc. & 0.49 & 0.49 & 0.00 & 0.00 & 0.05 & 0.42 & 0.44 \\
\hline $\mathrm{H}_{2} \mathrm{O}$ calc. & 3.56 & 3.56 & 4.30 & 4.42 & 4.37 & 3.73 & 3.69 \\
\hline $\mathrm{O}=\mathrm{F}$ & 0.77 & 0.77 & 0.14 & 0.03 & 0.17 & 0.67 & 0.69 \\
\hline Total & 99.86 & 99.57 & 98.94 & 98.52 & 101.32 & 100.77 & 100.58 \\
\hline \multicolumn{8}{|c|}{ Fórmula calculada na base de 22 oxigênios } \\
\hline $\mathrm{Si}$ & 6.103 & 6.129 & 6.459 & 6.430 & 6.487 & 6.083 & 6.073 \\
\hline Al iv & 1.897 & 1.871 & 1.541 & 1.570 & 1.513 & 1.917 & 1.927 \\
\hline Al vi & 3.541 & 3.535 & 3.664 & 3.718 & 3.624 & 3.581 & 3.570 \\
\hline $\mathrm{Ti}$ & 0.000 & 0.000 & 0.011 & 0.007 & 0.008 & 0.000 & 0.000 \\
\hline $\mathrm{Fe}$ & 0.514 & 0.489 & 0.274 & 0.216 & 0.286 & 0.417 & 0.430 \\
\hline $\mathrm{Mn}$ & 0.008 & 0.008 & 0.005 & 0.022 & 0.036 & 0.009 & 0.010 \\
\hline $\mathrm{Mg}$ & 0.014 & 0.011 & 0.031 & 0.021 & 0.022 & 0.076 & 0.064 \\
\hline $\mathrm{Zn}$ & 0.000 & 0.000 & 0.000 & 0.002 & 0.000 & 0.000 & 0.000 \\
\hline $\mathrm{Li}$ & 0.269 & 0.268 & 0.000 & 0.000 & 0.026 & 0.227 & 0.235 \\
\hline $\mathrm{Ca}$ & 0.003 & 0.000 & 0.000 & 0.000 & 0.000 & 0.003 & 0.001 \\
\hline $\mathrm{Na}$ & 0.143 & 0.187 & 0.200 & 0.168 & 0.168 & 0.168 & 0.182 \\
\hline $\mathrm{K}$ & 1.786 & 1.795 & 1.645 & 1.668 & 1.705 & 1.767 & 1.787 \\
\hline $\mathrm{Sr}$ & 0.000 & 0.000 & 0.000 & 0.000 & 0.000 & 0.000 & 0.000 \\
\hline $\mathrm{Ba}$ & 0.000 & 0.000 & 0.002 & 0.000 & 0.000 & 0.000 & 0.000 \\
\hline $\mathrm{Rb}$ & 0.000 & 0.000 & 0.034 & 0.027 & 0.023 & 0.000 & 0.000 \\
\hline Cs & 0.000 & 0.000 & 0.000 & 0.000 & 0.001 & 0.000 & 0.000 \\
\hline $\mathrm{OH}$ & 3.215 & 3.219 & 3.859 & 3.966 & 3.833 & 3.323 & 3.303 \\
\hline $\mathrm{F}$ & 0.785 & 0.781 & 0.141 & 0.034 & 0.167 & 0.677 & 0.697 \\
\hline
\end{tabular}




\begin{tabular}{|c|c|c|c|c|c|c|c|}
\hline & $\mathrm{Hmb} 10 \mathrm{C} 3$ & $\mathrm{Hmb} 10 \mathrm{C} 4$ & $\mathrm{Hmb} 10 \mathrm{C6}$ & $\mathrm{Hmb} 10 \mathrm{C} 7$ & $\mathrm{Hmb} 10 \mathrm{C} 8$ & Hmb10C9 & $\mathrm{Hmb} 10 \mathrm{C} 10$ \\
\hline $\mathrm{SiO}_{2}$ & 44.86 & 43.52 & 45.47 & 44.93 & 45.10 & 45.51 & 45.58 \\
\hline $\mathrm{TiO}_{2}$ & 0.00 & 0.01 & 0.00 & 0.00 & 0.00 & 0.00 & 0.03 \\
\hline $\mathrm{Al}_{2} \mathrm{O}_{3}$ & 33.56 & 33.26 & 34.01 & 33.99 & 34.23 & 34.15 & 33.93 \\
\hline $\mathrm{FeO}_{\text {Total }}$ & 4.41 & 4.69 & 4.32 & 4.21 & 4.72 & 4.46 & 4.52 \\
\hline $\mathrm{MnO}$ & 0.08 & 0.09 & 0.09 & 0.06 & 0.10 & 0.03 & 0.09 \\
\hline $\mathrm{MgO}$ & 0.04 & 0.07 & 0.06 & 0.04 & 0.03 & 0.10 & 0.07 \\
\hline $\mathrm{CaO}$ & 0.02 & 0.03 & 0.00 & 0.00 & 0.03 & 0.01 & 0.00 \\
\hline $\mathrm{Na}_{2} \mathrm{O}$ & 0.68 & 0.61 & 0.70 & 0.71 & 0.67 & 0.72 & 0.67 \\
\hline $\mathrm{K}_{2} \mathrm{O}$ & 10.47 & 10.14 & 10.41 & 10.19 & 10.02 & 10.10 & 10.15 \\
\hline $\mathrm{SrO}$ & 0.02 & 0.00 & 0.04 & 0.00 & 0.00 & 0.00 & 0.00 \\
\hline $\mathrm{BaO}$ & 0.08 & 0.00 & 0.03 & 0.00 & 0.13 & 0.00 & 0.00 \\
\hline \multicolumn{8}{|l|}{$\mathrm{Rb}_{2} \mathrm{O}$} \\
\hline $\mathrm{Cs}_{2} \mathrm{O}$ & 0.00 & 0.07 & 0.00 & 0.06 & 0.00 & 0.06 & 0.02 \\
\hline \multicolumn{8}{|l|}{$\mathrm{ZnO}$} \\
\hline $\mathrm{F}$ & 1.71 & 1.69 & 1.75 & 1.84 & 1.89 & 1.94 & 1.83 \\
\hline $\mathrm{Li}_{2} \mathrm{O}$ calc. & 0.41 & 0.45 & 0.42 & 0.40 & 0.40 & 0.32 & 0.43 \\
\hline $\mathrm{H}_{2} \mathrm{O}$ calc. & 3.65 & 3.57 & 3.64 & 3.74 & 3.73 & 3.80 & 3.71 \\
\hline $\mathrm{O}=\mathrm{F}$ & 0.65 & 0.71 & 0.68 & 0.64 & 0.65 & 0.54 & 0.69 \\
\hline Total & 98.78 & 98.38 & 98.87 & 100.13 & 100.11 & 98.71 & 100.63 \\
\hline \multicolumn{8}{|c|}{ Fórmula calculada na base de 22 oxigênios } \\
\hline $\mathrm{Si}$ & 6.124 & 6.078 & 6.117 & 6.117 & 6.123 & 6.063 & 6.079 \\
\hline $\mathrm{Al}$ iv & 1.876 & 1.922 & 1.883 & 1.883 & 1.877 & 1.937 & 1.921 \\
\hline Al vi & 3.551 & 3.546 & 3.578 & 3.592 & 3.588 & 3.642 & 3.575 \\
\hline $\mathrm{Ti}$ & 0.000 & 0.000 & 0.000 & 0.000 & 0.000 & 0.001 & 0.000 \\
\hline $\mathrm{Fe}$ & 0.421 & 0.450 & 0.407 & 0.432 & 0.408 & 0.364 & 0.411 \\
\hline $\mathrm{Mn}$ & 0.008 & 0.007 & 0.006 & 0.010 & 0.011 & 0.006 & 0.006 \\
\hline $\mathrm{Mg}$ & 0.067 & 0.069 & 0.051 & 0.053 & 0.061 & 0.057 & 0.071 \\
\hline $\mathrm{Zn}$ & 0.000 & 0.000 & 0.000 & 0.000 & 0.000 & 0.000 & 0.000 \\
\hline $\mathrm{Li}$ & 0.224 & 0.248 & 0.233 & 0.214 & 0.218 & 0.176 & 0.232 \\
\hline $\mathrm{Ca}$ & 0.004 & 0.000 & 0.001 & 0.000 & 0.002 & 0.003 & 0.002 \\
\hline $\mathrm{Na}$ & 0.157 & 0.196 & 0.174 & 0.147 & 0.169 & 0.220 & 0.185 \\
\hline $\mathrm{K}$ & 1.842 & 1.788 & 1.784 & 1.755 & 1.760 & 1.752 & 1.791 \\
\hline $\mathrm{Sr}$ & 0.000 & 0.000 & 0.009 & 0.000 & 0.000 & 0.000 & 0.003 \\
\hline $\mathrm{Ba}$ & 0.000 & 0.000 & 0.004 & 0.000 & 0.000 & 0.000 & 0.000 \\
\hline $\mathrm{Rb}$ & 0.000 & 0.000 & 0.000 & 0.000 & 0.000 & 0.000 & 0.000 \\
\hline Cs & 0.000 & 0.000 & 0.002 & 0.000 & 0.004 & 0.002 & 0.000 \\
\hline $\mathrm{OH}$ & 3.330 & 3.268 & 3.307 & 3.355 & 3.346 & 3.450 & 3.311 \\
\hline $\mathrm{F}$ & 0.670 & 0.732 & 0.693 & 0.645 & 0.654 & 0.550 & 0.689 \\
\hline
\end{tabular}




\begin{tabular}{|c|c|c|c|c|c|c|c|}
\hline & $\mathrm{Hmr} 12 \mathrm{~B}$ & Hmr12B2 & $\mathrm{Hmr} 12 \mathrm{~A} 2$ & Hmb13A1 & $\mathrm{Hmb} 13 \mathrm{~A} 2$ & $\mathrm{Hmb} 13 \mathrm{~A} 3$ & $\mathrm{Hmb} 13 \mathrm{~A} 4$ \\
\hline $\mathrm{SiO}_{2}$ & 52.28 & 52.41 & 54.10 & 44.82 & 44.49 & 45.23 & 45.21 \\
\hline $\mathrm{TiO}_{2}$ & 0.01 & 0.00 & 0.04 & 0.06 & 0.00 & 0.06 & 0.03 \\
\hline $\mathrm{Al}_{2} \mathrm{O}_{3}$ & 23.33 & 22.97 & 22.12 & 36.21 & 36.10 & 36.77 & 36.43 \\
\hline $\mathrm{FeO}_{\text {Total }}$ & 0.25 & 0.28 & 0.80 & 1.79 & 1.61 & 1.61 & 1.48 \\
\hline $\mathrm{MnO}$ & 1.20 & 1.09 & 0.97 & 0.05 & 0.09 & 0.05 & 0.00 \\
\hline $\mathrm{MgO}$ & 0.00 & 0.00 & 0.13 & 0.13 & 0.12 & 0.12 & 0.12 \\
\hline $\mathrm{CaO}$ & 0.01 & 0.04 & 0.04 & 0.00 & 0.00 & 0.00 & 0.03 \\
\hline $\mathrm{Na}_{2} \mathrm{O}$ & 0.39 & 0.28 & 0.42 & 0.89 & 0.86 & 0.92 & 0.74 \\
\hline $\mathrm{K}_{2} \mathrm{O}$ & 10.74 & 10.77 & 10.09 & 10.07 & 10.21 & 10.24 & 10.05 \\
\hline $\mathrm{SrO}$ & & & 0.00 & 0.00 & 0.07 & 0.06 & 0.00 \\
\hline $\mathrm{BaO}$ & 0.00 & 0.05 & 0.00 & 0.00 & 0.00 & 0.02 & 0.07 \\
\hline $\mathrm{Rb}_{2} \mathrm{O}$ & 1.99 & 2.40 & 2.09 & & & & \\
\hline $\mathrm{Cs}_{2} \mathrm{O}$ & 0.02 & 0.01 & 0.02 & 0.03 & 0.01 & 0.00 & 0.01 \\
\hline $\mathrm{ZnO}$ & & & 0.04 & & & & \\
\hline $\mathrm{F}$ & 8.25 & 8.44 & 8.95 & 1.14 & 0.92 & 1.05 & 1.08 \\
\hline $\mathrm{Li}_{2} \mathrm{O}$ calc. & 5.45 & 5.49 & 5.97 & 0.48 & 0.41 & 0.47 & 0.46 \\
\hline $\mathrm{H}_{2} \mathrm{O}$ calc. & 0.61 & 0.51 & 0.35 & 3.57 & 3.64 & 3.60 & 3.55 \\
\hline $\mathrm{O}=\mathrm{F}$ & 3.48 & 3.55 & 3.77 & 0.76 & 0.66 & 0.74 & 0.72 \\
\hline Total & 101.06 & 101.18 & 102.35 & 99.73 & 98.50 & 100.10 & 98.16 \\
\hline \multicolumn{8}{|c|}{ Fórmula calculada na base de 22 oxigênios } \\
\hline $\mathrm{Si}$ & 6.933 & 6.962 & 7.057 & 6.129 & 6.132 & 6.101 & 6.147 \\
\hline Al iv & 1.067 & 1.038 & 0.943 & 1.871 & 1.868 & 1.899 & 1.853 \\
\hline Al vi & 2.580 & 2.559 & 2.458 & 3.533 & 3.585 & 3.553 & 3.543 \\
\hline $\mathrm{Ti}$ & 0.000 & 0.000 & 0.004 & 0.003 & 0.000 & 0.000 & 0.000 \\
\hline $\mathrm{Fe}$ & 0.028 & 0.031 & 0.087 & 0.505 & 0.461 & 0.513 & 0.497 \\
\hline $\mathrm{Mn}$ & 0.135 & 0.123 & 0.107 & 0.003 & 0.003 & 0.011 & 0.009 \\
\hline $\mathrm{Mg}$ & 0.000 & 0.000 & 0.026 & 0.009 & 0.020 & 0.005 & 0.011 \\
\hline $\mathrm{Zn}$ & 0.000 & 0.000 & 0.004 & 0.000 & 0.000 & 0.000 & 0.000 \\
\hline $\mathrm{Li}$ & 2.908 & 2.933 & 3.134 & 0.264 & 0.226 & 0.257 & 0.252 \\
\hline $\mathrm{Ca}$ & 0.002 & 0.006 & 0.005 & 0.001 & 0.003 & 0.000 & 0.000 \\
\hline $\mathrm{Na}$ & 0.100 & 0.073 & 0.105 & 0.187 & 0.112 & 0.164 & 0.137 \\
\hline $\mathrm{K}$ & 1.817 & 1.825 & 1.678 & 1.763 & 1.803 & 1.755 & 1.790 \\
\hline $\mathrm{Sr}$ & 0.000 & 0.000 & 0.000 & 0.000 & 0.000 & 0.000 & 0.004 \\
\hline $\mathrm{Ba}$ & 0.000 & 0.002 & 0.000 & 0.000 & 0.000 & 0.000 & 0.000 \\
\hline $\mathrm{Rb}$ & 0.169 & 0.205 & 0.175 & 0.000 & 0.000 & 0.000 & 0.000 \\
\hline Cs & 0.001 & 0.001 & 0.001 & 0.008 & 0.001 & 0.005 & 0.000 \\
\hline $\mathrm{OH}$ & 0.538 & 0.454 & 0.308 & 3.230 & 3.325 & 3.247 & 3.258 \\
\hline $\mathrm{F}$ & 3.462 & 3.546 & 3.692 & 0.770 & 0.675 & 0.753 & 0.742 \\
\hline
\end{tabular}




\begin{tabular}{|c|c|c|c|c|c|c|c|}
\hline & Hmb13A5 & $\mathrm{Hmb13A7}$ & $\mathrm{Hmb} 13 \mathrm{~A} 8$ & Hmb13A9 & $\mathrm{Hmb13A10}$ & Hmb13B1 & $\mathrm{Hmb13B2}$ \\
\hline $\mathrm{SiO}_{2}$ & 44.91 & 45.75 & 45.46 & 45.38 & 45.60 & 45.36 & 45.06 \\
\hline $\mathrm{TiO}_{2}$ & 0.04 & 0.02 & 0.05 & 0.00 & 0.02 & 0.04 & 0.00 \\
\hline $\mathrm{Al}_{2} \mathrm{O}_{3}$ & 36.82 & 36.98 & 37.27 & 36.78 & 36.88 & 36.37 & 36.62 \\
\hline $\mathrm{FeO}_{\text {Total }}$ & 1.74 & 1.63 & 1.81 & 1.60 & 1.67 & 1.87 & 1.76 \\
\hline $\mathrm{MnO}$ & 0.06 & 0.06 & 0.06 & 0.04 & 0.00 & 0.06 & 0.06 \\
\hline $\mathrm{MgO}$ & 0.18 & 0.11 & 0.13 & 0.11 & 0.12 & 0.12 & 0.10 \\
\hline $\mathrm{CaO}$ & 0.03 & 0.00 & 0.00 & 0.00 & 0.00 & 0.01 & 0.00 \\
\hline $\mathrm{Na}_{2} \mathrm{O}$ & 0.92 & 0.83 & 0.85 & 0.84 & 0.90 & 0.75 & 0.81 \\
\hline $\mathrm{K}_{2} \mathrm{O}$ & 10.16 & 10.00 & 10.13 & 9.95 & 10.14 & 9.97 & 10.23 \\
\hline $\mathrm{SrO}$ & 0.07 & 0.04 & 0.13 & 0.06 & 0.00 & 0.05 & 0.00 \\
\hline $\mathrm{BaO}$ & 0.00 & 0.00 & 0.00 & 0.04 & 0.05 & 0.06 & 0.08 \\
\hline \multicolumn{8}{|l|}{$\mathrm{Rb}_{2} \mathrm{O}$} \\
\hline $\mathrm{Cs}_{2} \mathrm{O}$ & 0.00 & 0.01 & 0.05 & 0.04 & 0.05 & 0.04 & 0.00 \\
\hline \multicolumn{8}{|l|}{$\mathrm{ZnO}$} \\
\hline $\mathrm{F}$ & 1.26 & 1.31 & 1.19 & 1.17 & 1.05 & 1.11 & 1.24 \\
\hline $\mathrm{Li}_{2} \mathrm{O}$ calc. & 0.46 & 0.50 & 0.47 & 0.50 & 0.51 & 0.53 & 0.50 \\
\hline $\mathrm{H}_{2} \mathrm{O}$ calc. & 3.58 & 3.59 & 3.62 & 3.54 & 3.54 & 3.54 & 3.58 \\
\hline $\mathrm{O}=\mathrm{F}$ & 0.72 & 0.78 & 0.74 & 0.77 & 0.80 & 0.82 & 0.77 \\
\hline Total & 99.25 & 100.45 & 100.23 & 99.30 & 100.19 & 100.32 & 100.19 \\
\hline \multicolumn{8}{|c|}{ Fórmula calculada na base de 22 oxigênios } \\
\hline $\mathrm{Si}$ & 6.123 & 6.120 & 6.131 & 6.109 & 6.089 & 6.122 & 6.142 \\
\hline $\mathrm{Al}$ iv & 1.877 & 1.880 & 1.869 & 1.891 & 1.911 & 1.878 & 1.858 \\
\hline Al vi & 3.522 & 3.556 & 3.537 & 3.557 & 3.536 & 3.539 & 3.530 \\
\hline $\mathrm{Ti}$ & 0.000 & 0.000 & 0.000 & 0.000 & 0.000 & 0.000 & 0.003 \\
\hline $\mathrm{Fe}$ & 0.503 & 0.496 & 0.487 & 0.479 & 0.533 & 0.502 & 0.509 \\
\hline $\mathrm{Mn}$ & 0.009 & 0.003 & 0.011 & 0.007 & 0.011 & 0.003 & 0.010 \\
\hline $\mathrm{Mg}$ & 0.008 & 0.007 & 0.013 & 0.008 & 0.007 & 0.020 & 0.015 \\
\hline $\mathrm{Zn}$ & 0.000 & 0.000 & 0.000 & 0.000 & 0.000 & 0.000 & 0.000 \\
\hline $\mathrm{Li}$ & 0.250 & 0.270 & 0.254 & 0.272 & 0.279 & 0.286 & 0.268 \\
\hline $\mathrm{Ca}$ & 0.002 & 0.000 & 0.000 & 0.000 & 0.004 & 0.001 & 0.000 \\
\hline $\mathrm{Na}$ & 0.180 & 0.189 & 0.182 & 0.188 & 0.175 & 0.187 & 0.174 \\
\hline $\mathrm{K}$ & 1.823 & 1.733 & 1.790 & 1.767 & 1.726 & 1.733 & 1.744 \\
\hline $\mathrm{Sr}$ & 0.001 & 0.000 & 0.003 & 0.000 & 0.000 & 0.000 & 0.000 \\
\hline $\mathrm{Ba}$ & 0.004 & 0.001 & 0.002 & 0.000 & 0.007 & 0.000 & 0.000 \\
\hline $\mathrm{Rb}$ & 0.000 & 0.000 & 0.000 & 0.000 & 0.000 & 0.000 & 0.000 \\
\hline Cs & 0.000 & 0.006 & 0.000 & 0.004 & 0.000 & 0.003 & 0.001 \\
\hline $\mathrm{OH}$ & 3.262 & 3.214 & 3.254 & 3.209 & 3.192 & 3.175 & 3.218 \\
\hline $\mathrm{F}$ & 0.738 & 0.786 & 0.746 & 0.791 & 0.808 & 0.825 & 0.782 \\
\hline
\end{tabular}




\begin{tabular}{|c|c|c|c|c|c|c|c|}
\hline & $\mathrm{Hmb13B3}$ & $\mathrm{Hmb13B4}$ & $\mathrm{Hmb13B7}$ & Hmb13B8 & Hmb13B9 & $\mathrm{Hmb13B10}$ & Hmb13B11 \\
\hline $\mathrm{SiO}_{2}$ & 44.55 & 44.48 & 44.39 & 44.21 & 45.29 & 45.28 & 45.55 \\
\hline $\mathrm{TiO}_{2}$ & 0.00 & 0.01 & 0.02 & 0.06 & 0.00 & 0.09 & 0.01 \\
\hline $\mathrm{Al}_{2} \mathrm{O}_{3}$ & 36.15 & 36.25 & 36.05 & 36.02 & 36.44 & 36.70 & 36.86 \\
\hline $\mathrm{FeO}_{\text {Total }}$ & 1.87 & 1.91 & 1.66 & 1.84 & 1.84 & 1.74 & 1.70 \\
\hline $\mathrm{MnO}$ & 0.00 & 0.04 & 0.02 & 0.05 & 0.08 & 0.08 & 0.01 \\
\hline $\mathrm{MgO}$ & 0.11 & 0.13 & 0.14 & 0.10 & 0.08 & 0.12 & 0.13 \\
\hline $\mathrm{CaO}$ & 0.00 & 0.01 & 0.00 & 0.04 & 0.03 & 0.03 & 0.03 \\
\hline $\mathrm{Na}_{2} \mathrm{O}$ & 0.68 & 0.68 & 0.71 & 0.72 & 0.77 & 0.79 & 0.84 \\
\hline $\mathrm{K}_{2} \mathrm{O}$ & 10.27 & 10.41 & 10.36 & 10.31 & 10.22 & 10.21 & 10.19 \\
\hline $\mathrm{SrO}$ & 0.00 & 0.00 & 0.00 & 0.03 & 0.03 & 0.07 & 0.05 \\
\hline $\mathrm{BaO}$ & 0.00 & 0.08 & 0.02 & 0.00 & 0.07 & 0.02 & 0.00 \\
\hline \multicolumn{8}{|l|}{$\mathrm{Rb}_{2} \mathrm{O}$} \\
\hline $\mathrm{Cs}_{2} \mathrm{O}$ & 0.10 & 0.00 & 0.01 & 0.00 & 0.00 & 0.04 & 0.00 \\
\hline \multicolumn{8}{|l|}{$\mathrm{ZnO}$} \\
\hline $\mathrm{F}$ & 1.19 & 1.13 & 1.08 & 1.05 & 1.29 & 1.17 & 1.06 \\
\hline $\mathrm{Li}_{2} \mathrm{O}$ calc. & 0.00 & 0.27 & 0.26 & 0.25 & 0.33 & 0.29 & 0.25 \\
\hline $\mathrm{H}_{2} \mathrm{O}$ calc. & 3.85 & 3.90 & 3.90 & 3.91 & 3.88 & 3.95 & 4.02 \\
\hline $\mathrm{O}=\mathrm{F}$ & 0.50 & 0.47 & 0.46 & 0.44 & 0.54 & 0.49 & 0.44 \\
\hline Total & 98.27 & 98.82 & 98.16 & 98.16 & 99.81 & 100.08 & 100.26 \\
\hline \multicolumn{8}{|c|}{ Fórmula calculada na base de 22 oxigênios } \\
\hline $\mathrm{Si}$ & 6.051 & 6.012 & 6.028 & 6.012 & 6.049 & 6.029 & 6.045 \\
\hline $\mathrm{Al}$ iv & 1.949 & 1.988 & 1.972 & 1.988 & 1.951 & 1.971 & 1.955 \\
\hline Al vi & 3.839 & 3.786 & 3.800 & 3.786 & 3.784 & 3.789 & 3.809 \\
\hline $\mathrm{Ti}$ & 0.000 & 0.001 & 0.002 & 0.006 & 0.000 & 0.009 & 0.001 \\
\hline $\mathrm{Fe}$ & 0.212 & 0.216 & 0.189 & 0.209 & 0.206 & 0.194 & 0.188 \\
\hline $\mathrm{Mn}$ & 0.000 & 0.005 & 0.002 & 0.006 & 0.010 & 0.009 & 0.002 \\
\hline $\mathrm{Mg}$ & 0.021 & 0.026 & 0.028 & 0.021 & 0.017 & 0.024 & 0.026 \\
\hline $\mathrm{Zn}$ & 0.000 & 0.000 & 0.000 & 0.000 & 0.000 & 0.000 & 0.000 \\
\hline $\mathrm{Li}$ & 0.000 & 0.149 & 0.143 & 0.137 & 0.176 & 0.155 & 0.135 \\
\hline $\mathrm{Ca}$ & 0.001 & 0.001 & 0.000 & 0.006 & 0.004 & 0.004 & 0.004 \\
\hline $\mathrm{Na}$ & 0.180 & 0.178 & 0.186 & 0.190 & 0.200 & 0.203 & 0.217 \\
\hline $\mathrm{K}$ & 1.779 & 1.795 & 1.794 & 1.788 & 1.741 & 1.734 & 1.725 \\
\hline $\mathrm{Sr}$ & 0.000 & 0.000 & 0.000 & 0.002 & 0.002 & 0.005 & 0.004 \\
\hline $\mathrm{Ba}$ & 0.000 & 0.004 & 0.001 & 0.000 & 0.004 & 0.001 & 0.000 \\
\hline $\mathrm{Rb}$ & 0.000 & 0.000 & 0.000 & 0.000 & 0.000 & 0.000 & 0.000 \\
\hline $\mathrm{Cs}$ & 0.006 & 0.000 & 0.000 & 0.000 & 0.000 & 0.002 & 0.000 \\
\hline $\mathrm{OH}$ & 3.490 & 3.518 & 3.534 & 3.550 & 3.453 & 3.506 & 3.557 \\
\hline $\mathrm{F}$ & 0.510 & 0.482 & 0.466 & 0.450 & 0.547 & 0.494 & 0.443 \\
\hline
\end{tabular}




\begin{tabular}{|c|c|c|c|c|c|c|c|}
\hline & $\mathrm{Hmb13B12}$ & Hmb16B2 & $\mathrm{Hmb} 16 \mathrm{C} 2$ & $\mathrm{Hmb} 16 \mathrm{C} 3$ & $\mathrm{Hmb16D}$ & $\mathrm{Hmb16E}$ & $\mathrm{Hmb} 17 \mathrm{~A}$ \\
\hline $\mathrm{SiO}_{2}$ & 45.71 & 46.29 & 46.02 & 46.50 & 46.37 & 46.28 & 47.25 \\
\hline $\mathrm{TiO}_{2}$ & 0.07 & 0.00 & 0.00 & 0.06 & 0.00 & 0.02 & 0.00 \\
\hline $\mathrm{Al}_{2} \mathrm{O}_{3}$ & 36.64 & 33.23 & 33.03 & 32.62 & 32.96 & 33.07 & 31.25 \\
\hline $\mathrm{FeO}_{\text {Total }}$ & 1.87 & 2.03 & 2.62 & 2.50 & 2.71 & 2.58 & 3.60 \\
\hline $\mathrm{MnO}$ & 0.07 & 0.01 & 0.00 & 0.08 & 0.02 & 0.04 & 0.07 \\
\hline $\mathrm{MgO}$ & 0.11 & 0.27 & 0.27 & 0.27 & 0.29 & 0.28 & 0.51 \\
\hline $\mathrm{CaO}$ & 0.00 & 0.00 & 0.00 & 0.00 & 0.01 & 0.00 & 0.01 \\
\hline $\mathrm{Na}_{2} \mathrm{O}$ & 0.69 & 0.57 & 0.66 & 0.69 & 0.54 & 0.61 & 0.17 \\
\hline $\mathrm{K}_{2} \mathrm{O}$ & 10.33 & 10.72 & 10.78 & 10.86 & 10.90 & 10.90 & 11.29 \\
\hline $\mathrm{SrO}$ & 0.02 & & & & & & \\
\hline $\mathrm{BaO}$ & 0.05 & 0.09 & 0.02 & 0.00 & 0.01 & 0.05 & 0.05 \\
\hline $\mathrm{Rb}_{2} \mathrm{O}$ & & 0.28 & 0.21 & 0.28 & 0.16 & 0.20 & 0.17 \\
\hline $\mathrm{Cs}_{2} \mathrm{O}$ & 0.03 & 0.00 & 0.00 & 0.04 & 0.00 & 0.00 & 0.05 \\
\hline \multicolumn{8}{|l|}{$\mathrm{ZnO}$} \\
\hline $\mathrm{F}$ & 1.20 & 0.57 & 0.58 & 0.55 & 0.57 & 0.50 & 0.47 \\
\hline $\mathrm{Li}_{2} \mathrm{O}$ calc. & 0.30 & 0.10 & 0.10 & 0.10 & 0.10 & 0.08 & 0.07 \\
\hline $\mathrm{H}_{2} \mathrm{O}$ calc. & 3.95 & 4.12 & 4.11 & 4.13 & 4.13 & 4.16 & 4.17 \\
\hline $\mathrm{O}=\mathrm{F}$ & 0.51 & 0.24 & 0.24 & 0.23 & 0.24 & 0.21 & 0.20 \\
\hline Total & 100.53 & 98.03 & 98.17 & 98.42 & 98.53 & 98.57 & 98.93 \\
\hline \multicolumn{8}{|c|}{ Fórmula calculada na base de 22 oxigênios } \\
\hline $\mathrm{Si}$ & 6.059 & 6.319 & 6.295 & 6.346 & 6.317 & 6.306 & 6.449 \\
\hline $\mathrm{Al}$ iv & 1.941 & 1.681 & 1.705 & 1.654 & 1.683 & 1.694 & 1.551 \\
\hline Al vi & 3.782 & 3.666 & 3.620 & 3.594 & 3.610 & 3.618 & 3.476 \\
\hline $\mathrm{Ti}$ & 0.007 & 0.000 & 0.000 & 0.006 & 0.000 & 0.002 & 0.000 \\
\hline $\mathrm{Fe}$ & 0.207 & 0.232 & 0.299 & 0.286 & 0.309 & 0.294 & 0.411 \\
\hline $\mathrm{Mn}$ & 0.008 & 0.001 & 0.000 & 0.009 & 0.003 & 0.005 & 0.008 \\
\hline $\mathrm{Mg}$ & 0.022 & 0.055 & 0.056 & 0.054 & 0.060 & 0.057 & 0.104 \\
\hline $\mathrm{Zn}$ & 0.000 & 0.000 & 0.000 & 0.000 & 0.000 & 0.000 & 0.000 \\
\hline $\mathrm{Li}$ & 0.159 & 0.056 & 0.058 & 0.053 & 0.056 & 0.044 & 0.039 \\
\hline $\mathrm{Ca}$ & 0.000 & 0.000 & 0.000 & 0.000 & 0.002 & 0.000 & 0.001 \\
\hline $\mathrm{Na}$ & 0.178 & 0.150 & 0.175 & 0.183 & 0.143 & 0.162 & 0.046 \\
\hline $\mathrm{K}$ & 1.746 & 1.866 & 1.881 & 1.890 & 1.893 & 1.895 & 1.966 \\
\hline $\mathrm{Sr}$ & 0.002 & 0.000 & 0.000 & 0.000 & 0.000 & 0.000 & 0.000 \\
\hline $\mathrm{Ba}$ & 0.002 & 0.005 & 0.001 & 0.000 & 0.000 & 0.003 & 0.002 \\
\hline $\mathrm{Rb}$ & 0.000 & 0.025 & 0.019 & 0.024 & 0.014 & 0.017 & 0.015 \\
\hline Cs & 0.002 & 0.000 & 0.000 & 0.002 & 0.000 & 0.000 & 0.003 \\
\hline $\mathrm{OH}$ & 3.496 & 3.754 & 3.749 & 3.762 & 3.754 & 3.784 & 3.795 \\
\hline $\mathrm{F}$ & 0.504 & 0.246 & 0.251 & 0.238 & 0.246 & 0.216 & 0.205 \\
\hline
\end{tabular}




\begin{tabular}{|c|c|c|c|c|c|c|c|}
\hline & $\mathrm{Hmb17B}$ & $\mathrm{Hmb} 18 \mathrm{C}$ & $\mathrm{Hmb18D}$ & $\mathrm{Hmb18E}$ & Hf18A & Hf18D1 & Hf18D2 \\
\hline $\mathrm{SiO}_{2}$ & 48.02 & 46.07 & 47.24 & 46.70 & 45.94 & 46.39 & 46.27 \\
\hline $\mathrm{TiO}_{2}$ & 0.00 & 0.01 & 0.04 & 0.02 & 0.19 & 0.08 & 0.18 \\
\hline $\mathrm{Al}_{2} \mathrm{O}_{3}$ & 34.73 & 33.71 & 33.57 & 33.28 & 34.94 & 35.12 & 35.72 \\
\hline $\mathrm{FeO}_{\text {Total }}$ & 1.07 & 1.66 & 1.79 & 1.78 & 1.78 & 2.07 & 1.90 \\
\hline $\mathrm{MnO}$ & 0.07 & 0.05 & 0.04 & 0.09 & 0.04 & 0.05 & 0.03 \\
\hline $\mathrm{MgO}$ & 0.00 & 0.54 & 0.54 & 0.57 & 0.55 & 0.59 & 0.44 \\
\hline $\mathrm{CaO}$ & 0.00 & 0.00 & 0.01 & 0.00 & 0.07 & 0.03 & 0.01 \\
\hline $\mathrm{Na}_{2} \mathrm{O}$ & 0.19 & 0.71 & 0.59 & 0.68 & 0.51 & 0.69 & 0.47 \\
\hline $\mathrm{K}_{2} \mathrm{O}$ & 11.21 & 10.75 & 10.67 & 10.72 & 10.32 & 10.10 & 10.34 \\
\hline \multicolumn{8}{|l|}{$\mathrm{SrO}$} \\
\hline \multicolumn{8}{|l|}{$\mathrm{BaO}$} \\
\hline $\mathrm{Rb}_{2} \mathrm{O}$ & 0.00 & 0.00 & 0.00 & 0.00 & & & \\
\hline $\mathrm{Cs}_{2} \mathrm{O}$ & 0.18 & 0.17 & 0.07 & 0.25 & 0.00 & 0.00 & 0.00 \\
\hline $\mathrm{ZnO}$ & 0.04 & 0.00 & 0.08 & 0.07 & 0.00 & 0.00 & 0.04 \\
\hline \multicolumn{8}{|l|}{$\mathrm{F}$} \\
\hline $\mathrm{Li}_{2} \mathrm{O}$ calc. & 0.14 & 0.18 & 0.20 & 0.16 & 0.23 & 0.18 & 0.23 \\
\hline $\mathrm{H}_{2} \mathrm{O}$ calc. & 0.00 & 0.00 & 0.00 & 0.00 & 0.00 & 0.00 & 0.00 \\
\hline $\mathrm{O}=\mathrm{F}$ & 0.06 & 0.08 & 0.08 & 0.07 & 0.10 & 0.08 & 0.10 \\
\hline Total & 100.03 & 98.09 & 99.11 & 98.59 & 98.81 & 99.63 & 99.91 \\
\hline \multicolumn{8}{|c|}{ Fórmula calculada na base de 22 oxigênios } \\
\hline $\mathrm{Si}$ & 6.372 & 6.272 & 6.351 & 6.331 & 6.184 & 6.193 & 6.158 \\
\hline $\mathrm{Al}$ iv & 1.628 & 1.728 & 1.649 & 1.669 & 1.816 & 1.807 & 1.842 \\
\hline Al vi & 3.803 & 3.682 & 3.670 & 3.650 & 3.728 & 3.720 & 3.762 \\
\hline $\mathrm{Ti}$ & 0.000 & 0.001 & 0.004 & 0.002 & 0.019 & 0.008 & 0.018 \\
\hline $\mathrm{Fe}$ & 0.119 & 0.189 & 0.201 & 0.201 & 0.200 & 0.231 & 0.211 \\
\hline $\mathrm{Mn}$ & 0.007 & 0.006 & 0.005 & 0.010 & 0.005 & 0.005 & 0.003 \\
\hline $\mathrm{Mg}$ & 0.001 & 0.109 & 0.108 & 0.115 & 0.111 & 0.117 & 0.088 \\
\hline $\mathrm{Zn}$ & 0.000 & 0.000 & 0.000 & 0.000 & 0.000 & 0.000 & 0.000 \\
\hline $\mathrm{Li}$ & 0.000 & 0.000 & 0.000 & 0.000 & 0.000 & 0.000 & 0.000 \\
\hline $\mathrm{Ca}$ & 0.000 & 0.000 & 0.001 & 0.000 & 0.010 & 0.004 & 0.001 \\
\hline $\mathrm{Na}$ & 0.048 & 0.188 & 0.155 & 0.180 & 0.133 & 0.178 & 0.122 \\
\hline $\mathrm{K}$ & 1.897 & 1.867 & 1.829 & 1.854 & 1.771 & 1.721 & 1.755 \\
\hline $\mathrm{Sr}$ & 0.000 & 0.000 & 0.000 & 0.000 & 0.000 & 0.000 & 0.000 \\
\hline $\mathrm{Ba}$ & 0.000 & 0.000 & 0.000 & 0.000 & 0.000 & 0.000 & 0.000 \\
\hline $\mathrm{Rb}$ & 0.015 & 0.015 & 0.006 & 0.022 & 0.000 & 0.000 & 0.000 \\
\hline Cs & 0.002 & 0.000 & 0.004 & 0.004 & 0.000 & 0.000 & 0.002 \\
\hline $\mathrm{OH}$ & 3.940 & 3.923 & 3.915 & 3.931 & 3.903 & 3.924 & 3.904 \\
\hline $\mathrm{F}$ & 0.060 & 0.077 & 0.085 & 0.069 & 0.097 & 0.076 & 0.096 \\
\hline
\end{tabular}


SCHORLITAS E DRAVITAS 


\begin{tabular}{|c|c|c|c|c|c|c|c|c|c|c|c|c|c|c|c|c|}
\hline & $01 \mathrm{~A}$ & 01B & $01 \mathrm{C}$ & 01D & $01 E$ & $01 F$ & $02 \mathrm{~A}$ & 02B & $02 \mathrm{C}$ & 02D & $02 E$ & 03A & 03B & $03 \mathrm{C}$ & 03D & 03E \\
\hline $\mathrm{SiO}_{2}$ & 35.78 & 36.84 & 38.93 & 37.39 & 37.84 & 38.17 & 38.73 & 38.64 & 39.09 & 39.03 & 39.26 & 34.67 & 34.85 & 34.76 & 34.57 & 35.58 \\
\hline $\mathrm{TiO}_{2}$ & 0.23 & 0.16 & 0.02 & 0.08 & 0.25 & 0.18 & 0.64 & 0.38 & 0.42 & 0.37 & 0.46 & 0.38 & 0.33 & 0.31 & 0.38 & 0.12 \\
\hline $\mathrm{Al}_{2} \mathrm{O}_{3}$ & 33.23 & 33.18 & 35.99 & 34.00 & 32.95 & 33.68 & 30.30 & 31.19 & 31.48 & 31.32 & 31.93 & 33.62 & 32.95 & 33.04 & 33.49 & 37.04 \\
\hline $\mathrm{FeO} \neq$ & 14.43 & 15.16 & 9.22 & 11.57 & 11.23 & 11.36 & 4.52 & 4.42 & 4.19 & 4.78 & 4.43 & 12.46 & 12.50 & 12.50 & 12.46 & 8.33 \\
\hline MgO & 1.07 & 0.47 & 0.23 & 2.51 & 2.97 & 2.57 & 8.82 & 8.51 & 8.58 & 8.47 & 8.53 & 2.79 & 3.49 & 3.33 & 2.52 & 0.05 \\
\hline MnO & 0.23 & 0.29 & 1.46 & 0.12 & 0.13 & 0.12 & 0.02 & 0.00 & 0.01 & 0.00 & 0.02 & 0.33 & 0.24 & 0.28 & 0.36 & 1.93 \\
\hline $\mathrm{CaO}$ & 0.13 & 0.10 & 0.08 & 0.11 & 0.2 & 0.18 & 1.50 & 0.54 & 0.50 & 0.52 & 0.85 & 0.35 & 0.32 & 0.37 & 0.37 & 0.18 \\
\hline $\mathrm{Na}_{2} \mathrm{O}$ & 2.06 & 1.96 & 2.53 & 1.76 & 2.19 & 2.04 & 1.92 & 2.45 & 2.45 & 2.49 & 2.26 & 2.28 & 2.33 & 2.28 & 2.26 & 2.51 \\
\hline $\mathbf{K}_{2} \mathbf{O}$ & 0.05 & 0.06 & 0.05 & 0.05 & 0.06 & 0.09 & 0.04 & 0.08 & 0.04 & 0.06 & 0.04 & 0.05 & 0.05 & 0.04 & 0.05 & 0.04 \\
\hline $\mathbf{F}$ & 0.53 & 0.55 & 1.13 & 0.12 & 0.24 & 0.19 & 0.62 & 0.48 & 0.41 & 0.37 & 0.43 & 0.30 & 0.23 & 0.31 & 0.28 & 0.86 \\
\hline $\mathbf{H}_{2} \mathbf{O}^{*}$ & 3.35 & 3.39 & 3.29 & 3.65 & 3.61 & 3.66 & 3.48 & 3.54 & 3.61 & 3.63 & 3.64 & 3.46 & 3.49 & 3.45 & 3.45 & 3.68 \\
\hline $\mathrm{B}_{2} \mathrm{O}_{3} *$ & 10.45 & 10.59 & 11.08 & 10.74 & 10.79 & 10.88 & 10.94 & 10.92 & 11.02 & 11.01 & 11.13 & 10.44 & 10.44 & 10.42 & 10.39 & 10.67 \\
\hline $\mathbf{L i}_{2} \mathbf{O}^{*}$ & 0.30 & 0.49 & 1.41 & 0.48 & 0.72 & 0.76 & 0.87 & 0.78 & 0.83 & 0.80 & 0.79 & 0.16 & 0.06 & 0.08 & 0.22 & 1.01 \\
\hline Total & 101.62 & 103.01 & 104.94 & 102.53 & 103.08 & 103.8 & 102.14 & 101.73 & 102.46 & 102.7 & 103.59 & 101.16 & 101.18 & 101.04 & 100.68 & 101.64 \\
\hline $\mathbf{O}=\mathbf{F}$ & -0.22 & -0.23 & -0.48 & -0.05 & -0.10 & -0.08 & -0.26 & -0.20 & -0.17 & -0.15 & -0.18 & -0.13 & -0.10 & -0.13 & -0.12 & -0.36 \\
\hline
\end{tabular}




\begin{tabular}{|c|c|c|c|c|c|c|c|c|c|c|c|c|c|c|c|}
\hline & 05A & 05B & 05C & 05D & 05E & $05 F$ & 05G & 05H & $11 \mathrm{~A}$ & 11B & 11C & 11D & $11 E$ & $14 A$ & 14B \\
\hline $\mathrm{SiO} 2$ & 34.79 & 36.5 & 38.01 & 37.38 & 36.3 & 34.76 & 35.17 & 35.51 & 35.71 & 35.13 & 35.63 & 35.05 & 35.5 & 38.94 & 39.6 \\
\hline TiO2 & 0.23 & 0.26 & 0.31 & 0.26 & 0.25 & 0.34 & 0.1 & 0.33 & 0.65 & 0.77 & 0.69 & 0.85 & 0.79 & 0.42 & 0.41 \\
\hline Al203 & 37.29 & 32.65 & 33.99 & 34.16 & 33.3 & 33.55 & 32.56 & 32.68 & 32.44 & 33.02 & 32.77 & 32.69 & 32.93 & 31.15 & 31.96 \\
\hline $\mathrm{FeO} \neq$ & 8.21 & 13.63 & 12.84 & 14.17 & 13.63 & 14.2 & 14.63 & 13.83 & 8.87 & 10.13 & 8.17 & 11.58 & 11.82 & 4.69 & 4.38 \\
\hline MgO & 0.2 & 1.09 & 1.26 & 0.66 & 1 & 1 & 0.91 & 1.7 & 5.08 & 2.95 & 5.03 & 2.74 & 3.02 & 8.4 & 8.52 \\
\hline $\mathrm{MnO}$ & 1.6 & 0.52 & 0.6 & 0.55 & 0.63 & 0.51 & 0.51 & 0.26 & 0.23 & 0.44 & 0.16 & 0.33 & 0.28 & 0 & 0.03 \\
\hline $\mathrm{CaO}$ & 0.96 & 0.47 & 0.32 & 0.21 & 0.35 & 0.27 & 0.76 & 0.36 & 0.22 & 0.07 & 0.16 & 0.05 & 0.07 & 0.49 & 1.3 \\
\hline $\mathrm{Na} 2 \mathrm{O}$ & 2.29 & 2.25 & 2.39 & 2.1 & 2.25 & 2.31 & 2.05 & 2.23 & 2.52 & 2.52 & 2.62 & 2.64 & 2.59 & 2.5 & 1.86 \\
\hline K2O & 0.02 & 0.06 & 0.08 & 0.07 & 0.07 & 0.08 & 0.01 & 0.07 & 0.08 & 0.06 & 0.07 & 0.04 & 0.09 & 0.07 & 0.08 \\
\hline $\mathbf{F}$ & 0.96 & 0.75 & 0.84 & 0.46 & 0.72 & 0.69 & 0.47 & 0.28 & 1.08 & 1.15 & 1.15 & 0.91 & 0.93 & 0.48 & 0.5 \\
\hline H2O* & 3.21 & 3.28 & 3.37 & 3.51 & 3.3 & 3.25 & 3.34 & 3.46 & 3.12 & 3.04 & 3.09 & 3.16 & 3.19 & 3.56 & 3.62 \\
\hline B203* & 10.63 & 10.53 & 10.92 & 10.8 & 10.56 & 10.38 & 10.33 & 10.42 & 10.52 & 10.4 & 10.51 & 10.40 & 10.52 & 10.97 & 11.19 \\
\hline Li20* & 1.06 & 0.6 & 0.78 & 0.54 & 0.49 & 0.31 & 0.38 & 0.33 & 0.29 & 0.46 & 0.37 & 0.37 & 0.32 & 0.83 & 0.89 \\
\hline Total & 101.05 & 102.27 & 105.36 & 104.68 & 102.55 & 101.36 & 101.02 & 101.34 & 100.36 & 99.66 & 99.94 & 100.43 & 101.66 & 102.3 & 104.13 \\
\hline $\mathrm{O}=\mathrm{F}$ & -0.40 & -0.32 & -0.35 & -0.19 & -0.30 & -0.29 & -0.20 & -0.12 & -0.45 & -0.48 & -0.48 & -0.38 & -0.39 & -0.20 & -0.21 \\
\hline
\end{tabular}




\begin{tabular}{|c|c|c|c|c|c|c|c|c|c|c|c|c|c|c|c|c|}
\hline & 01A & 01B & 01C & 01D & 01E & 01F & 02A & 02B & 02C & 02D & 02E & 03A & 03B & 03C & O3D & 03E \\
\hline \multicolumn{17}{|c|}{ SÍTIO X } \\
\hline $\mathrm{Ca}$ & 0.02 & 0.02 & 0.01 & 0.02 & 0.04 & 0.03 & 0.26 & 0.09 & 0.08 & 0.09 & 0.14 & 0.06 & 0.06 & 0.07 & 0.07 & 0.03 \\
\hline $\mathrm{Na}$ & 0.66 & 0.62 & 0.77 & 0.55 & 0.68 & 0.63 & 0.59 & 0.76 & 0.75 & 0.76 & 0.69 & 0.74 & 0.75 & 0.74 & 0.73 & 0.79 \\
\hline $\mathbf{K}$ & 0.01 & 0.01 & 0.01 & 0.01 & 0.01 & 0.02 & 0.01 & 0.02 & 0.01 & 0.01 & 0.01 & 0.01 & 0.01 & 0.01 & 0.01 & 0.01 \\
\hline$\square$ & 0.30 & 0.35 & 0.21 & 0.42 & 0.27 & 0.32 & 0.14 & 0.14 & 0.16 & 0.14 & 0.16 & 0.19 & 0.18 & 0.19 & 0.19 & 0.17 \\
\hline$\sum x$ & 1.00 & 1.00 & 1.00 & 1.00 & 1.00 & 1.00 & 1.00 & 1.00 & 1.00 & 1.00 & 1.00 & 1.00 & 1.00 & 1.00 & 1.00 & 1.00 \\
\hline \multicolumn{17}{|c|}{ SÍTIO Y* } \\
\hline Al & 0.47 & 0.42 & 0.65 & 0.49 & 0.26 & 0.34 & 0.00 & 0.00 & 0.00 & 0.00 & 0.00 & 0.37 & 0.27 & 0.29 & 0.38 & 0.93 \\
\hline $\mathrm{Ti}$ & 0.03 & 0.02 & - & 0.01 & 0.03 & 0.02 & 0.08 & 0.05 & 0.05 & 0.04 & 0.05 & 0.05 & 0.04 & 0.04 & 0.05 & 0.02 \\
\hline $\mathrm{Mg}$ & 0.27 & 0.12 & 0.05 & 0.61 & 0.71 & 0.61 & 1.76 & 1.87 & 1.87 & 1.82 & 1.87 & 0.69 & 0.87 & 0.83 & 0.63 & 0.01 \\
\hline Mn & 0.03 & 0.04 & 0.19 & 0.02 & 0.02 & 0.02 & 0.00 & 0.00 & 0.00 & 0.00 & 0.00 & 0.05 & 0.03 & 0.04 & 0.05 & 0.27 \\
\hline $\mathrm{Fe}$ & 2.01 & 2.08 & 1.21 & 1.57 & 1.51 & 1.52 & 0.60 & 0.59 & 0.55 & 0.63 & 0.58 & 1.73 & 1.74 & 1.74 & 1.74 & 1.14 \\
\hline Li & 0.20 & 0.32 & 0.89 & 0.32 & 0.47 & 0.49 & 0.56 & 0.50 & 0.53 & 0.51 & 0.50 & 0.11 & 0.04 & 0.05 & 0.15 & 0.64 \\
\hline$\Sigma Y$ & 3.00 & 3.00 & 3.00 & 3.00 & 3.00 & 3.00 & 3.00 & 3.00 & 3.00 & 3.00 & 3.00 & 3.00 & 3.00 & 3.00 & 3.00 & 2.99 \\
\hline \multicolumn{17}{|c|}{ SÍTIO Z } \\
\hline Al & 6 & 6 & 6 & 6 & 6 & 6 & 5.68 & 5.85 & 5.85 & 5.83 & 5.88 & 6 & 6 & 6 & 6 & 6 \\
\hline $\mathrm{Mg}$ & - & - & - & - & - & - & 0.32 & 0.15 & 0.15 & 0.17 & 0.12 & - & - & - & - & - \\
\hline \multicolumn{17}{|c|}{ sÍTIO T } \\
\hline Si & 5.95 & 6.05 & 6.11 & 6.05 & 6.10 & 6.10 & 6.15 & 6.15 & 6.16 & 6.16 & 6.13 & 5.77 & 5.80 & 5.80 & 5.78 & 5.81 \\
\hline Al & 0.05 & - & - & - & - & - & - & - & - & - & - & 0.23 & 0.20 & 0.20 & 0.22 & 0.20 \\
\hline \multicolumn{17}{|c|}{ SÍTIO B } \\
\hline B* & 3 & 3 & 3 & 3 & 3 & 3 & 3 & 3 & 3 & 3 & 3 & 3 & 3 & 3 & 3 & 3 \\
\hline \multicolumn{17}{|c|}{ sÍTIO W + SÍTIO V } \\
\hline $\mathbf{F}$ & 0.28 & 0.29 & 0.56 & 0.06 & 0.12 & 0.10 & 0.31 & 0.24 & 0.21 & 0.18 & 0.21 & 0.16 & 0.12 & 0.16 & 0.15 & 0.44 \\
\hline OH & 3.72 & 3.71 & 3.44 & 3.94 & 3.88 & 3.90 & 3.69 & 3.76 & 3.80 & 3.82 & 3.79 & 3.84 & 3.88 & 3.84 & 3.85 & 3.56 \\
\hline
\end{tabular}




\begin{tabular}{|c|c|c|c|c|c|c|c|c|c|c|c|c|c|c|c|}
\hline & 05A & 05B & 05C & 05D & 05E & $05 \mathrm{~F}$ & 05G & 05H & $11 \mathrm{~A}$ & 11B & $11 C$ & 11D & $11 \mathrm{E}$ & $14 \mathrm{~A}$ & 14B \\
\hline \multicolumn{16}{|c|}{ SÍTIO X } \\
\hline $\mathrm{Ca}$ & 0.17 & 0.08 & 0.06 & 0.04 & 0.06 & 0.05 & 0.14 & 0.06 & 0.05 & 0.01 & 0.03 & 0.01 & 0.01 & 0.08 & 0.22 \\
\hline $\mathrm{Na}$ & 0.73 & 0.72 & 0.74 & 0.66 & 0.72 & 0.75 & 0.67 & 0.72 & 0.79 & 0.82 & 0.84 & 0.86 & 0.83 & 0.77 & 0.56 \\
\hline K & 0.00 & 0.01 & 0.02 & 0.01 & 0.02 & 0.02 & 0.00 & 0.02 & 0.02 & 0.01 & 0.01 & 0.01 & 0.02 & 0.01 & 0.02 \\
\hline$\square$ & 0.10 & 0.19 & 0.19 & 0.29 & 0.21 & 0.19 & 0.19 & 0.20 & 0.15 & 0.16 & 0.12 & 0.13 & 0.14 & 0.14 & 0.21 \\
\hline$\Sigma x$ & 1.00 & 1.00 & 1.00 & 1.00 & 1.00 & 1.00 & 1.00 & 1.00 & 1.00 & 1.00 & 1.00 & 1.00 & 1.00 & 1.00 & 1.00 \\
\hline \multicolumn{16}{|c|}{ SÍTIO Y* } \\
\hline Al & 0.88 & 0.35 & 0.37 & 0.48 & 0.43 & 0.44 & 0.37 & 0.35 & 0.22 & 0.38 & 0.27 & 0.29 & 0.28 & 0.00 & 0.00 \\
\hline $\mathrm{Ti}$ & 0.03 & 0.03 & 0.04 & 0.03 & 0.03 & 0.04 & 0.01 & 0.04 & 0.08 & 0.10 & 0.09 & 0.11 & 0.10 & 0.05 & 0.05 \\
\hline $\mathrm{Mg}$ & 0.05 & 0.27 & 0.30 & 0.16 & 0.25 & 0.25 & 0.23 & 0.42 & 1.36 & 0.74 & 1.24 & 0.68 & 0.74 & 1.80 & 1.82 \\
\hline $\mathrm{Mn}$ & 0.22 & 0.07 & 0.08 & 0.08 & 0.09 & 0.07 & 0.07 & 0.04 & 0.03 & 0.06 & 0.02 & 0.05 & 0.04 & 0.00 & 0.00 \\
\hline $\mathrm{Fe}$ & 1.12 & 1.88 & 1.71 & 1.91 & 1.88 & 1.99 & 2.06 & 1.93 & 1.13 & 1.42 & 1.13 & 1.62 & 1.63 & 0.62 & 0.57 \\
\hline $\mathbf{L i}$ & 0.70 & 0.40 & 0.50 & 0.35 & 0.33 & 0.21 & 0.26 & 0.22 & 0.17 & 0.31 & 0.25 & 0.25 & 0.21 & 0.53 & 0.56 \\
\hline$\Sigma Y$ & 3.00 & 3.00 & 3.00 & 3.00 & 3.01 & 3.00 & 3.00 & 3.00 & 2.97 & 3.00 & 2.99 & 3.00 & 3.00 & 3.00 & 3.00 \\
\hline \multicolumn{16}{|c|}{ SÍTIO Z } \\
\hline Al & 6 & 6 & 6 & 6 & 6 & 6 & 6 & 6 & 6 & 6 & 6 & 6 & 6 & 5.81 & 5.85 \\
\hline $\mathrm{Mg}$ & - & - & - & - & - & - & - & - & - & - & - & - & - & 0.19 & 0.15 \\
\hline \multicolumn{16}{|c|}{ SÍTIO T } \\
\hline Si & 5.69 & 6.02 & 6.04 & 6.01 & 5.97 & 5.82 & 5.92 & 5.92 & 5.90 & 5.87 & 5.89 & 5.86 & 5.87 & 6.17 & 6.15 \\
\hline Al & 0.31 & - & - & - & 0.03 & 0.18 & 0.08 & 0.08 & 0.11 & 0.13 & 0.11 & 0.14 & 0.14 & - & - \\
\hline \multicolumn{16}{|c|}{ SÍTIO B } \\
\hline B* $^{*}$ & 3 & 3 & 3 & 3 & 3 & 3 & 3 & 3 & 3 & 3 & 3 & 3 & 3 & 3 & 3 \\
\hline \multicolumn{16}{|c|}{ sÍTIO W + sÍTIO V } \\
\hline $\mathbf{F}$ & 0.31 & 0.39 & 0.42 & 0.23 & 0.38 & 0.37 & 0.25 & 0.15 & 0.52 & 0.61 & 0.60 & 0.48 & 0.49 & 0.24 & 0.25 \\
\hline OH & 3.69 & 3.61 & 3.58 & 3.77 & 3.63 & 3.64 & 3.75 & 3.85 & 3.48 & 3.39 & 3.40 & 3.52 & 3.51 & 3.76 & 3.75 \\
\hline
\end{tabular}


ELBAÍTA, LIDDICOATITA, ROSSMANITA 


\begin{tabular}{|c|c|c|c|c|c|c|c|c|c|c|c|c|c|c|c|c|c|c|c|c|}
\hline & tm1A1 & tm1A2 & tm1B1 & tm1B2 & tm1D1 & $\operatorname{tr} 1 \mathrm{~A}$ & tr1B & $\operatorname{tr} 1 \mathrm{C}$ & tr1D & $\operatorname{tr} 1 \mathrm{E}$ & $\operatorname{tr} 1 F$ & $\operatorname{tr} 1 G$ & tr1H & tr11 & tr1J & tr1K & tv1A & tv1B & tv1C & ti1A \\
\hline \multicolumn{21}{|c|}{ SÍTIO X } \\
\hline $\mathrm{Ca}$ & 0.05 & 0.09 & 0.15 & 0.07 & 0.01 & 0.05 & 0.11 & 0.11 & 0.08 & 0.08 & 0.07 & 0.05 & 0.05 & 0.02 & 0.02 & 0.02 & 0.11 & 0.06 & 0.06 & 0.03 \\
\hline $\mathrm{Na}$ & 0.61 & 0.70 & 0.54 & 0.62 & 0.58 & 0.65 & 0.58 & 0.59 & 0.66 & 0.37 & 0.66 & 0.64 & 0.58 & 0.62 & 0.62 & 0.63 & 0.61 & 0.68 & 0.66 & 0.67 \\
\hline K & 0.00 & 0.01 & 0.00 & 0.01 & 0.00 & 0.00 & 0.01 & 0.00 & 0.00 & 0.01 & 0.00 & 0.01 & 0.00 & 0.01 & 0.01 & 0.01 & 0.01 & 0.01 & 0.01 & 0.01 \\
\hline$\square$ & 0.34 & 0.20 & 0.32 & 0.30 & 0.40 & 0.30 & 0.31 & 0.30 & 0.27 & 0.55 & 0.28 & 0.30 & 0.37 & 0.35 & 0.35 & 0.34 & 0.28 & 0.26 & 0.28 & 0.29 \\
\hline$\Sigma x$ & 1.00 & 1.00 & 1.00 & 1.00 & 1.00 & 1.00 & 1.00 & 1.00 & 1.00 & 1.00 & 1.00 & 1.00 & 1.00 & 1.00 & 1.00 & 1.00 & 1.00 & 1.00 & 1.00 & 1.00 \\
\hline \multicolumn{21}{|c|}{ síTIO Y* } \\
\hline Al & 1.66 & 1.38 & 1.60 & 1.53 & 1.74 & 1.59 & 1.58 & 1.56 & 1.51 & 1.63 & 1.47 & 1.27 & 1.41 & 1.51 & 1.48 & 1.56 & 1.50 & 1.33 & 1.40 & 1.20 \\
\hline $\mathrm{Ti}$ & 0.00 & 0.00 & 0.00 & 0.00 & 0.00 & 0.00 & 0.00 & 0.00 & 0.00 & 0.00 & 0.00 & 0.00 & 0.00 & 0.00 & 0.00 & 0.00 & 0.00 & 0.00 & 0.00 & 0.00 \\
\hline $\mathrm{Mg}$ & 0.00 & 0.05 & 0.00 & 0.00 & 0.00 & 0.00 & 0.00 & 0.01 & 0.00 & 0.01 & 0.00 & 0.00 & 0.00 & 0.00 & 0.00 & 0.00 & 0.00 & 0.00 & 0.00 & 0.00 \\
\hline $\mathrm{Mn}$ & 0.01 & 0.24 & 0.03 & 0.07 & 0.01 & 0.20 & 0.15 & 0.10 & 0.28 & 0.13 & 0.31 & 0.20 & 0.10 & 0.14 & 0.13 & 0.13 & 0.09 & 0.15 & 0.14 & 0.14 \\
\hline $\mathrm{Fe}$ & 0.00 & 0.19 & 0.00 & 0.22 & 0.00 & 0.00 & 0.00 & 0.00 & 0.03 & 0.01 & 0.03 & 0.01 & 0.00 & 0.00 & 0.00 & 0.00 & 0.15 & 0.11 & 0.12 & 0.12 \\
\hline $\mathbf{L i}$ & 1.32 & 1.18 & 1.37 & 1.16 & 1.25 & 1.21 & 1.27 & 1.33 & 1.18 & 1.21 & 1.18 & 1.52 & 1.48 & 1.35 & 1.39 & 1.31 & 1.26 & 1.41 & 1.34 & 1.54 \\
\hline$\Sigma Y$ & 2.99 & 3.04 & 3.00 & 2.97 & 3.00 & 2.99 & 2.99 & 3.00 & 3.00 & 3.00 & 2.99 & 3.00 & 2.99 & 2.99 & 3.00 & 2.99 & 2.99 & 3.00 & 3.00 & 3.00 \\
\hline \multicolumn{21}{|c|}{ SÍTIO Z } \\
\hline Al & 6 & 6 & 6 & 6 & 6 & 6 & 6 & 6 & 6 & 6 & 6 & 6 & 6 & 6 & 6 & 6 & 6 & 6 & 6 & 6 \\
\hline \multicolumn{21}{|c|}{ SÍTIO T } \\
\hline $\mathbf{S i}$ & 5.95 & 5.91 & 5.94 & 5.86 & 5.90 & 5.87 & 5.88 & 5.96 & 5.86 & 6.01 & 5.91 & 6.13 & 6.10 & 6.04 & 6.06 & 6.02 & 5.93 & 6.07 & 6.04 & 6.15 \\
\hline Al & 0.05 & 0.09 & 0.06 & 0.15 & 0.10 & 0.14 & 0.12 & 0.04 & 0.14 & 0.00 & 0.09 & 0.00 & 0.00 & 0.00 & 0.00 & 0.00 & 0.07 & 0.00 & 0.00 & 0.00 \\
\hline \multicolumn{21}{|c|}{ SÍTIO B } \\
\hline B* & 3 & 3 & 3 & 3 & 3 & 3 & 3 & 3 & 3 & 3 & 3 & 3 & 3 & 3 & 3 & 3 & 3 & 3 & 3 & 3 \\
\hline \multicolumn{21}{|c|}{ SÍTIO W + SÍTIO V } \\
\hline $\mathbf{F}$ & 0.49 & 0.58 & 0.54 & 0.57 & 0.41 & 0.47 & 0.42 & 0.47 & 0.51 & 0.42 & 0.57 & 0.45 & 0.42 & 0.46 & 0.46 & 0.42 & 0.53 & 0.59 & 0.60 & 0.62 \\
\hline OH & 3.51 & 3.42 & 3.46 & 3.44 & 3.59 & 3.53 & 3.58 & 3.53 & 3.49 & 3.58 & 3.44 & 3.55 & 3.58 & 3.54 & 3.54 & 3.58 & 3.47 & 3.42 & 3.40 & 3.38 \\
\hline
\end{tabular}




\begin{tabular}{|c|c|c|c|c|c|c|c|c|c|c|c|c|c|c|c|c|c|c|c|c|}
\hline & tv3A1 & tv3A2 & $\operatorname{tm} 3 A 1$ & tm3A2 & $\operatorname{tm} 3 \mathrm{D} 2$ & tm3D1 & tm3B1 & $\operatorname{tm} 3 B 2$ & $\operatorname{tm} 3 \mathrm{C} 1$ & $\operatorname{tm} 3 \mathrm{C} 2$ & $\operatorname{tm} 3 E$ & tv5A & tv5B & tv5C & $\operatorname{tr} 5 A$ & $\operatorname{tr} 5 B$ & $\operatorname{tr} 5 \mathrm{C}$ & $\operatorname{tr} 5 \mathrm{D}$ & $\operatorname{tr} 5 \mathrm{E}$ & $\operatorname{tr} 5 \mathrm{~F}$ \\
\hline \multicolumn{21}{|c|}{ SÍTIO X } \\
\hline $\mathbf{C a}$ & 0.14 & 0.13 & 0.06 & 0.50 & 0.26 & 0.25 & 0.14 & 0.12 & 0.25 & 0.10 & 0.13 & 0.20 & 0.34 & 0.66 & 0.50 & 0.52 & 0.52 & 0.47 & 0.47 & 0.37 \\
\hline $\mathbf{N a}$ & 0.76 & 0.77 & 0.53 & 0.38 & 0.55 & 0.49 & 0.53 & 0.64 & 0.49 & 0.66 & 0.63 & 0.66 & 0.54 & 0.31 & 0.36 & 0.31 & 0.32 & 0.41 & 0.42 & 0.48 \\
\hline $\mathbf{K}$ & 0.01 & 0.01 & 0.00 & 0.00 & 0.00 & 0.01 & 0.00 & 0.00 & 0.00 & 0.00 & 0.00 & 0.01 & 0.01 & 0.00 & 0.02 & 0.00 & 0.00 & 0.00 & 0.00 & 0.00 \\
\hline$\square$ & 0.10 & 0.10 & 0.41 & 0.12 & 0.18 & 0.25 & 0.34 & 0.24 & 0.26 & 0.23 & 0.25 & 0.13 & 0.12 & 0.03 & 0.13 & 0.16 & 0.16 & 0.12 & 0.11 & 0.14 \\
\hline$\sum \mathbf{X}$ & 1.00 & 1.00 & 1.00 & 1.00 & 1.00 & 1.00 & 1.00 & 1.00 & 1.00 & 1.00 & 1.00 & 1.00 & 1.00 & 1.00 & 1.00 & 0.99 & 1.00 & 1.00 & 1.00 & 1.00 \\
\hline \multicolumn{21}{|c|}{ SÍTIO Y* } \\
\hline Al & 1.17 & 1.15 & 1.74 & 1.28 & 1.36 & 1.55 & 1.65 & 1.47 & 1.57 & 1.47 & 1.50 & 0.97 & 0.98 & 0.87 & 1.38 & 1.41 & 1.38 & 1.21 & 1.19 & 1.16 \\
\hline $\mathbf{T i}$ & 0.02 & 0.01 & 0.00 & 0.00 & 0.01 & 0.00 & 0.00 & 0.00 & 0.00 & 0.01 & 0.00 & 0.00 & 0.00 & 0.00 & 0.00 & 0.00 & 0.00 & 0.00 & 0.00 & 0.00 \\
\hline Mg & 0.01 & 0.01 & 0.00 & 0.02 & 0.00 & 0.00 & 0.00 & 0.00 & 0.00 & 0.00 & 0.00 & 0.00 & 0.00 & 0.00 & 0.00 & 0.00 & 0.00 & 0.00 & 0.00 & 0.00 \\
\hline Mn & 0.40 & 0.48 & 0.02 & 0.03 & 0.06 & 0.05 & 0.00 & 0.06 & 0.03 & 0.08 & 0.06 & 0.44 & 0.36 & 0.07 & 0.02 & 0.02 & 0.03 & 0.11 & 0.11 & 0.11 \\
\hline $\mathbf{F e}$ & 0.34 & 0.35 & 0.00 & 0.13 & 0.19 & 0.00 & 0.00 & 0.18 & 0.00 & 0.19 & 0.16 & 0.11 & 0.07 & 0.10 & 0.00 & 0.00 & 0.00 & 0.00 & 0.00 & 0.00 \\
\hline $\mathbf{L i}$ & 1.06 & 1.00 & 1.24 & 1.54 & 1.37 & 1.39 & 1.35 & 1.28 & 1.40 & 1.25 & 1.27 & 1.48 & 1.60 & 1.96 & 1.58 & 1.56 & 1.58 & 1.68 & 1.70 & 1.74 \\
\hline$\sum \mathbf{Y}$ & 3.00 & 3.00 & 2.99 & 3.00 & 2.99 & 2.99 & 2.99 & 2.99 & 2.99 & 3.00 & 2.98 & 3.00 & 3.00 & 3.00 & 2.99 & 2.99 & 2.99 & 3.00 & 3.00 & 3.00 \\
\hline \multicolumn{21}{|c|}{ SÍTIO Z } \\
\hline Al & 6 & 6 & 6 & 6 & 6 & 6 & 6 & 6 & 6 & 6 & 6 & 6 & 6 & 6 & 6 & 6 & 6 & 6 & 6 & 6 \\
\hline \multicolumn{21}{|c|}{ SÍTIO T } \\
\hline Si & 5.82 & 5.79 & 5.84 & 5.88 & 5.90 & 5.84 & 5.90 & 5.91 & 5.83 & 5.89 & 5.87 & 6.11 & 6.10 & 6.12 & 5.82 & 5.80 & 5.83 & 6.03 & 6.04 & 6.09 \\
\hline Al & 0.19 & 0.21 & 0.16 & 0.12 & 0.10 & 0.16 & 0.10 & 0.09 & 0.17 & 0.11 & 0.13 & 0.00 & 0.00 & 0.00 & 0.18 & 0.21 & 0.17 & 0.00 & 0.00 & 0.00 \\
\hline \multicolumn{21}{|c|}{ SÍTIO B } \\
\hline $\mathbf{B}^{*}$ & 3 & 3 & 3 & 3 & 3 & 3 & 3 & 3 & 3 & 3 & 3 & 3 & 3 & 3 & 3 & 3 & 3 & 3 & 3 & 3 \\
\hline \multicolumn{21}{|c|}{ SÍTIO W + SÍTIO V } \\
\hline $\mathbf{F}$ & 0.65 & 0.65 & 0.27 & 0.66 & 0.59 & 0.43 & 0.45 & 0.50 & 0.51 & 0.55 & 0.55 & 0.72 & 0.76 & 0.90 & 0.57 & 0.54 & 0.67 & 0.70 & 0.75 & 0.61 \\
\hline $\mathbf{O H}$ & 3.35 & 3.35 & 3.73 & 3.34 & 3.41 & 3.57 & 3.56 & 3.50 & 3.49 & 3.45 & 3.45 & 3.28 & 3.24 & 3.10 & 3.43 & 3.46 & 3.33 & 3.30 & 3.26 & 3.39 \\
\hline
\end{tabular}


ta11A $\quad$ ta11A2 ta11B ta11C ta11D tv11A tv11B tv11C tv11D tv11E ta12A $\quad$ ta12B ta12C ta12D ta12E ta12F

\begin{tabular}{|c|c|c|c|c|c|c|c|c|c|c|c|c|c|c|c|c|}
\hline \multicolumn{17}{|c|}{ síTIO X } \\
\hline $\mathrm{Ca}$ & 0.02 & 0.02 & 0.08 & 0.04 & 0.05 & 0.02 & 0.02 & 0.01 & 0.03 & 0.02 & 0.05 & 0.06 & 0.05 & 0.05 & 0.05 & 0.06 \\
\hline $\mathrm{Na}$ & 0.86 & 0.84 & 0.71 & 0.68 & 0.74 & 0.87 & 0.90 & 0.90 & 0.92 & 1.02 & 0.88 & 0.83 & 0.86 & 0.86 & 0.85 & 0.84 \\
\hline K & 0.00 & 0.00 & 0.00 & 0.01 & 0.01 & 0.00 & 0.00 & 0.01 & 0.01 & 0.01 & 0.01 & 0.01 & 0.00 & 0.00 & 0.01 & 0.00 \\
\hline$\square$ & 0.13 & 0.14 & 0.21 & 0.28 & 0.20 & 0.10 & 0.08 & 0.08 & 0.05 & 0.00 & 0.07 & 0.11 & 0.09 & 0.09 & 0.10 & 0.10 \\
\hline$\Sigma x$ & 1.00 & 1.00 & 1.00 & 1.00 & 1.00 & 1.00 & 1.00 & 1.00 & 1.00 & 1.04 & 1.00 & 1.00 & 1.00 & 1.00 & 1.00 & 1.00 \\
\hline \multicolumn{17}{|c|}{ SÍTIO Y* } \\
\hline Al & 1.14 & 1.18 & 1.37 & 1.44 & 1.32 & 1.11 & 1.08 & 1.14 & 1.06 & 0.96 & 1.16 & 1.12 & 1.12 & 1.20 & 1.17 & 1.09 \\
\hline $\mathrm{Ti}$ & 0.00 & 0.00 & 0.00 & 0.00 & 0.00 & 0.00 & 0.02 & 0.03 & 0.02 & 0.04 & 0.00 & 0.00 & 0.00 & 0.00 & 0.00 & 0.00 \\
\hline $\mathrm{Mg}$ & 0.01 & 0.01 & 0.00 & 0.01 & 0.01 & 0.21 & 0.20 & 0.17 & 0.23 & 0.21 & 0.03 & 0.14 & 0.12 & 0.02 & 0.03 & 0.13 \\
\hline$M n$ & 0.11 & 0.11 & 0.32 & 0.19 & 0.19 & 0.06 & 0.05 & 0.06 & 0.07 & 0.05 & 0.19 & 0.12 & 0.10 & 0.19 & 0.19 & 0.11 \\
\hline $\mathrm{Fe}$ & 0.81 & 0.78 & 0.18 & 0.29 & 0.39 & 0.58 & 0.56 & 0.53 & 0.54 & 0.71 & 0.62 & 0.71 & 0.71 & 0.52 & 0.57 & 0.74 \\
\hline $\mathbf{L i}$ & 0.92 & 0.91 & 1.13 & 1.07 & 1.10 & 1.01 & 1.08 & 1.07 & 1.07 & 1.04 & 1.00 & 0.91 & 0.94 & 1.06 & 1.03 & 0.93 \\
\hline$\Sigma Y$ & 3.00 & 3.00 & 3.00 & 3.00 & 3.00 & 2.98 & 3.00 & 3.00 & 3.00 & 3.00 & 3.00 & 3.00 & 2.99 & 3.00 & 2.99 & 3.00 \\
\hline \multicolumn{17}{|c|}{ SÍTIO Z } \\
\hline Al & 6 & 6 & 6 & 6 & 6 & 6 & 6 & 6 & 6 & 6 & 6 & 6 & 6 & 6 & 6 & 6 \\
\hline \multicolumn{17}{|c|}{ síTIO T } \\
\hline $\mathbf{S i}$ & 5.89 & 5.85 & 5.89 & 5.87 & 5.92 & 5.93 & 6.00 & 5.93 & 5.98 & 5.95 & 5.85 & 5.83 & 5.85 & 5.90 & 5.89 & 5.87 \\
\hline Al & 0.12 & 0.15 & 0.11 & 0.13 & 0.08 & 0.07 & 0.00 & 0.07 & 0.02 & 0.05 & 0.15 & 0.17 & 0.15 & 0.10 & 0.11 & 0.13 \\
\hline \multicolumn{17}{|c|}{ SÍTIO B } \\
\hline $\mathrm{B}^{*}$ & 3 & 3 & 3 & 3 & 3 & 3 & 3 & 3 & 3 & 3 & 3 & 3 & 3 & 3 & 3 & 3 \\
\hline \multicolumn{17}{|c|}{ SÍTIO W + SÍTIO V } \\
\hline $\mathbf{F}$ & 0.73 & 0.70 & 0.62 & 0.57 & 0.62 & 0.76 & 0.83 & 0.77 & 0.78 & 0.82 & 0.74 & 0.72 & 0.68 & 0.71 & 0.73 & 0.74 \\
\hline $\mathrm{OH}$ & 3.27 & 3.30 & 3.38 & 3.43 & 3.38 & 3.24 & 3.17 & 3.23 & 3.22 & 3.18 & 3.26 & 3.28 & 3.32 & 3.29 & 3.27 & 3.26 \\
\hline
\end{tabular}




\begin{tabular}{ccccccccccccccccc}
\hline & mr1A & mv1A & mr1B & mv1B & mr1D & R1A & R1B & R1C & R1D & R1E & R1F & R1G & R1H & R1I & R1J & R1K \\
\hline SiO2 & 37.94 & 37.24 & 38.35 & 37.35 & 38.32 & 37.82 & 37.85 & 38.73 & 37.71 & 37.94 & 36.73 & 40.17 & 41.36 & 40.52 & 40.21 & 39.29 \\
TiO2 & 0.02 & 0.00 & 0.00 & 0.03 & 0.00 & 0.00 & 0.01 & 0 & 0.00 & 0.00 & 0.01 & 0 & 0 & 0 & 0 & 0 \\
Al2O3 & 41.64 & 39.90 & 41.89 & 41.52 & 43.19 & 42.25 & 42.04 & 41.867 & 41.78 & 40.83 & 39.92 & 40.42 & 42.68 & 42.71 & 42.11 & 41.87 \\
FeO & 0.01 & 1.44 & 0.01 & 1.68 & 0.00 & 0.04 & 0.00 & 0 & 0.19 & 0.09 & 0.22 & 0.08 & 0.05 & 0.05 & 0.04 & 0.03 \\
MgO & 0.01 & 0.02 & 0.00 & 0.10 & 0.00 & 0.01 & 0.00 & 0.05 & 0.02 & 0.06 & 0.01 & 0 & 0 & 0 & 0 & 0.01 \\
MnO & 0.10 & 1.78 & 0.24 & 0.52 & 0.04 & 1.51 & 1.11 & 0.728 & 2.14 & 0.98 & 2.30 & 1.56 & 0.79 & 1.1 & 0.98 & 1.02 \\
CaO & 0.28 & 0.50 & 0.88 & 0.40 & 0.08 & 0.31 & 0.63 & 0.642 & 0.46 & 0.44 & 0.38 & 0.31 & 0.34 & 0.15 & 0.13 & 0.14 \\
Na2O & 2.00 & 2.28 & 1.78 & 2.05 & 1.94 & 2.16 & 1.92 & 1.99 & 2.18 & 1.19 & 2.10 & 2.16 & 2.02 & 2.13 & 2.12 & 2.11 \\
K2O & 0.02 & 0.03 & 0.01 & 0.06 & 0.02 & 0.02 & 0.03 & 0.02 & 0.00 & 0.06 & 0.01 & 0.04 & 0.02 & 0.04 & 0.03 & 0.04 \\
F & 0.98 & 1.16 & 1.10 & 1.14 & 0.85 & 0.96 & 0.86 & 0.97 & 1.03 & 0.84 & 1.11 & 0.93 & 0.91 & 0.97 & 0.97 & 0.87 \\
H2O & 3.36 & 3.23 & 3.35 & 3.28 & 3.49 & 3.41 & 3.45 & 3.43 & 3.37 & 3.39 & 3.21 & 3.49 & 3.64 & 3.56 & 3.52 & 3.50 \\
B2O3 & 11.08 & 10.94 & 11.21 & 11.09 & 11.29 & 11.21 & 11.18 & 11.29 & 11.19 & 10.99 & 10.81 & 11.39 & 11.79 & 11.65 & 11.53 & 11.35 \\
Li20 & 2.10 & 1.85 & 2.20 & 1.84 & 2.02 & 1.94 & 2.03 & 2.15 & 1.89 & 2.05 & 1.82 & 2.48 & 2.50 & 2.25 & 2.29 & 2.12 \\
Total & 99.06 & 99.88 & 100.5 & 100.49 & 100.81 & 101.16 & 100.76 & 101.381 & 101.44 & 98.45 & 98.13 & 102.56 & 105.64 & 104.64 & 103.44 & 101.91 \\
O=F & -0.49 & -0.58 & -0.55 & -0.57 & -0.43 & -0.48 & -0.43 & -0.49 & -0.52 & -0.42 & -0.56 & -0.47 & -0.46 & -0.49 & -0.49 & -0.44 \\
\hline
\end{tabular}




\begin{tabular}{|c|c|c|c|c|c|c|c|c|c|c|c|c|c|c|c|c|}
\hline & R1K & V1A & V1B & V1C & I1A & tv3A1 & tv3A2 & tm3A1 & $\operatorname{tm} 3 A 2$ & tm3D2 & tm3D1 & tm3B1 & tm3B2 & $\operatorname{tm} 3 \mathrm{C} 1$ & $\operatorname{tm} 3 \mathrm{C} 2$ & tm3E \\
\hline $\mathrm{SiO2}$ & 39.29 & 38.02 & 39.03 & 39.39 & 41.27 & 36.43 & 36.08 & 37.32 & 37.04 & 37.50 & 37.49 & 37.72 & 37.63 & 37.51 & 36.96 & 37.34 \\
\hline TiO2 & 0 & 0.00 & 0 & 0.02 & 0 & 0.14 & 0.11 & 0.02 & 0.01 & 0.09 & 0.00 & 0.00 & 0.06 & 0.01 & 0.08 & 0.06 \\
\hline Al2O3 & 41.87 & 41.21 & 39.98 & 40.97 & 41 & 39.11 & 38.91 & 42.82 & 39.59 & 40.21 & 41.95 & 41.99 & 40.82 & 42.25 & 40.34 & 41.15 \\
\hline $\mathrm{FeO}$ & 0.03 & 1.11 & 0.82 & 0.92 & 0.937 & 2.53 & 2.63 & 0.02 & 0.98 & 1.43 & 0.05 & 0.01 & 1.39 & 0.01 & 1.44 & 1.20 \\
\hline MgO & 0.01 & 0.02 & 0.02 & 0.01 & 0.02 & 0.02 & 0.02 & 0.00 & 0.09 & 0.02 & 0.01 & 0.00 & 0.01 & 0.01 & 0.00 & 0.02 \\
\hline $\mathrm{MnO}$ & 1.02 & 0.67 & 1.15 & 1.1 & 1.09 & 2.96 & 3.50 & 0.13 & 0.20 & 0.46 & 0.37 & 0.05 & 0.47 & 0.21 & 0.58 & 0.43 \\
\hline $\mathrm{CaO}$ & 0.14 & 0.65 & 0.338 & 0.376 & 0.176 & 0.79 & 0.74 & 0.37 & 2.93 & 1.55 & 1.51 & 0.81 & 0.70 & 1.48 & 0.60 & 0.74 \\
\hline $\mathrm{Na} 2 \mathrm{O}$ & 2.11 & 2.01 & 2.24 & 2.21 & 2.32 & 2.45 & 2.46 & 1.74 & 1.23 & 1.81 & 1.62 & 1.73 & 2.10 & 1.64 & 2.15 & 2.05 \\
\hline K2O & 0.04 & 0.03 & 0.03 & 0.03 & 0.05 & 0.03 & 0.03 & 0.01 & 0.01 & 0.02 & 0.05 & 0.01 & 0.02 & 0.01 & 0.00 & 0.01 \\
\hline $\mathbf{F}$ & 0.87 & 1.08 & 1.19 & 1.24 & 1.31 & 1.28 & 1.28 & 0.55 & 1.31 & 1.18 & 0.88 & 0.90 & 1.00 & 1.04 & 1.09 & 1.10 \\
\hline $\mathrm{H} 2 \mathrm{O}$ & 3.50 & 3.34 & 3.29 & 3.33 & 3.40 & 3.15 & 3.13 & 3.57 & 3.16 & 3.25 & 3.43 & 3.41 & 3.34 & 3.36 & 3.25 & 3.29 \\
\hline B2O3 & 11.35 & 11.15 & 11.17 & 11.34 & 11.66 & 10.89 & 10.83 & 11.11 & 10.96 & 11.04 & 11.15 & 11.11 & 11.07 & 11.18 & 10.90 & 11.05 \\
\hline Li20 & 2.12 & 2.01 & 2.25 & 2.17 & 2.57 & 1.66 & 1.55 & 1.97 & 2.42 & 2.16 & 2.22 & 2.14 & 2.02 & 2.23 & 1.95 & 2.01 \\
\hline Total & 101.91 & 100.8 & 100.908 & 102.486 & 105.143 & 100.87 & 100.67 & 99.37 & 99.33 & 100.17 & 100.29 & 99.44 & 100.2 & 100.44 & 98.8 & 99.93 \\
\hline$O=F$ & -0.44 & -0.54 & -0.60 & -0.62 & -0.66 & -0.64 & -0.64 & -0.28 & -0.66 & -0.59 & -0.44 & -0.45 & -0.50 & -0.52 & -0.55 & -0.55 \\
\hline
\end{tabular}




\begin{tabular}{|c|c|c|c|c|c|c|c|c|c|c|c|c|c|c|c|c|}
\hline & tv5A & tv5B & tv5C & $\operatorname{tr} 5 \mathrm{~A}$ & $\operatorname{tr} 5 B$ & $\operatorname{tr} 5 \mathrm{C}$ & $\operatorname{tr} 5 \mathrm{D}$ & $\operatorname{tr} 5 \mathrm{E}$ & $\operatorname{tr} 5 \mathrm{~F}$ & ta11A & ta11A2 & ta11B & ta11C & ta11D & tv11A & tv11B \\
\hline $\mathrm{SiO2}$ & 39.08 & 39 & 39.10 & 37.03 & 37.24 & 37.53 & 38.31 & 38.43 & 38.88 & 36.17 & 36.1 & 36.7 & 36.74 & 36.89 & 36.72 & 37.59 \\
\hline TiO2 & 0.02 & 0.01 & 0.01 & 0.00 & 0 & 0 & 0.00 & 0.00 & 0.00 & 0.01 & 0.01 & 0.02 & 0 & 0.01 & 0.2 & 0.19 \\
\hline Al203 & 37.87 & 37.85 & 37.24 & 40.78 & 41.5 & 41.18 & 38.87 & 38.84 & 38.79 & 37.84 & 38.44 & 39.55 & 40.18 & 39.14 & 37.73 & 37.64 \\
\hline $\mathrm{FeO}$ & 0.84 & 0.53 & 0.75 & 0.05 & 0 & 0 & 0.02 & 0.02 & 0.01 & 5.97 & 5.78 & 1.33 & 2.19 & 2.88 & 4.28 & 4.22 \\
\hline MgO & 0 & 0 & 0.01 & 0.02 & 0.02 & 0 & 0.00 & 0.01 & 0.00 & 0.05 & 0.05 & 0 & 0.02 & 0.02 & 0.88 & 0.85 \\
\hline MnO & 3.29 & 2.7 & 0.55 & 0.18 & 0.18 & 0.22 & 0.82 & 0.82 & 0.80 & 0.83 & 0.81 & 2.33 & 1.39 & 1.39 & 0.47 & 0.39 \\
\hline $\mathrm{CaO}$ & 1.22 & 2 & 3.91 & 2.95 & 3.11 & 3.11 & 2.78 & 2.80 & 2.22 & 0.09 & 0.11 & 0.46 & 0.22 & 0.29 & 0.12 & 0.13 \\
\hline $\mathrm{Na} 2 \mathrm{O}$ & 2.17 & 1.79 & 1.02 & 1.17 & 1.02 & 1.06 & 1.35 & 1.37 & 1.59 & 2.71 & 2.68 & 2.27 & 2.18 & 2.38 & 2.78 & 2.91 \\
\hline K2O & 0.03 & 0.03 & 0.01 & 0.10 & 0.02 & 0.01 & 0.02 & 0.02 & 0.01 & 0.02 & 0.01 & 0.02 & 0.03 & 0.03 & 0.02 & 0.01 \\
\hline $\mathbf{F}$ & 1.46 & 1.54 & 1.81 & 1.15 & 1.1 & 1.37 & 1.41 & 1.50 & 1.23 & 1.41 & 1.36 & 1.22 & 1.12 & 1.22 & 1.48 & 1.64 \\
\hline $\mathrm{H} 2 \mathrm{O}$ & 3.15 & 3.1 & 2.97 & 3.27 & 3.33 & 3.21 & 3.14 & 3.11 & 3.25 & 3.02 & 3.06 & 3.16 & 3.22 & 3.16 & 3.01 & 2.98 \\
\hline B2O3 & 11.12 & 11.11 & 11.11 & 11.05 & 11.17 & 11.18 & 11.04 & 11.07 & 11.10 & 10.68 & 10.73 & 10.83 & 10.87 & 10.83 & 10.76 & 10.89 \\
\hline Li2O & 2.35 & 2.54 & 3.11 & 2.5 & 2.5 & 2.53 & 2.65 & 2.69 & 2.76 & 1.4 & 1.4 & 1.76 & 1.67 & 1.7 & 1.55 & 1.68 \\
\hline Total & 101.87 & 101.43 & 100.69 & 99.67 & 100.64 & 100.71 & 99.7 & 99.93 & 100.02 & 99.61 & 99.97 & 99.14 & 99.36 & 99.43 & 99.38 & 100.43 \\
\hline$O=F$ & -0.73 & -0.77 & -0.91 & -0.58 & -0.55 & -0.69 & -0.71 & -0.75 & -0.62 & -0.59 & -0.57 & -0.51 & -0.47 & -0.51 & -0.62 & -0.69 \\
\hline
\end{tabular}




\begin{tabular}{|c|c|c|c|c|c|c|c|c|c|}
\hline & tv11C & tv11D & tv11E & ta12A & ta12B & ta12C & ta12D & ta12E & ta12F \\
\hline $\mathrm{SiO2}$ & 37.1 & 37.56 & 37.63 & 36.39 & 36.44 & 36.16 & 36.63 & 36.39 & 36.15 \\
\hline TiO2 & 0.23 & 0.16 & 0.3 & 0.01 & 0 & 0.011 & 0 & 0.02 & 0.01 \\
\hline Al2O3 & 38.2 & 37.71 & 37.64 & 38.58 & 38.65 & 38.06 & 38.47 & 38.15 & 37.71 \\
\hline $\mathrm{FeO}$ & 3.96 & 4.08 & 5.34 & 4.63 & 5.29 & 5.27 & 3.86 & 4.17 & 5.43 \\
\hline MgO & 0.73 & 0.97 & 0.87 & 0.12 & 0.58 & 0.49 & 0.09 & 0.12 & 0.54 \\
\hline MnO & 0.47 & 0.55 & 0.39 & 1.37 & 0.85 & 0.74 & 1.42 & 1.4 & 0.77 \\
\hline $\mathrm{CaO}$ & 0.07 & 0.16 & 0.09 & 0.27 & 0.33 & 0.27 & 0.3 & 0.28 & 0.32 \\
\hline $\mathrm{Na2O}$ & 2.91 & 2.97 & 3.34 & 2.81 & 2.67 & 2.73 & 2.75 & 2.7 & 2.66 \\
\hline K2O & 0.04 & 0.04 & 0.03 & 0.03 & 0.03 & 0.02 & 0.02 & 0.03 & 0.02 \\
\hline $\mathbf{F}$ & 1.53 & 1.54 & 1.64 & 1.45 & 1.42 & 1.32 & 1.4 & 1.43 & 1.44 \\
\hline $\mathrm{H} 2 \mathrm{O}$ & 3.02 & 3.03 & 3.02 & 3.04 & 3.07 & 3.08 & 3.06 & 3.03 & 3.01 \\
\hline B2O3 & 10.87 & 10.91 & 11 & 10.81 & 10.86 & 10.74 & 10.79 & 10.74 & 10.7 \\
\hline Li20 & 1.66 & 1.67 & 1.64 & 1.54 & 1.42 & 1.44 & 1.64 & 1.58 & 1.42 \\
\hline Total & 100.15 & 100.7 & 102.24 & 100.32 & 100.9 & 99.671 & 99.73 & 99.32 & 99.46 \\
\hline $\mathrm{O}=\mathrm{F}$ & -0.64 & -0.65 & -0.69 & -0.73 & -0.71 & -0.66 & -0.70 & -0.72 & -0.72 \\
\hline
\end{tabular}


ANFIBÓLIO CÁLCICO 


\begin{tabular}{|c|c|c|c|c|c|c|c|c|c|c|c|c|c|c|c|c|c|}
\hline & \multicolumn{6}{|c|}{ ZONA 2} & \multicolumn{6}{|c|}{ ZONA 1} & \multicolumn{5}{|c|}{ ZONA H } \\
\hline & anf.1 & anf. 2 & anf.3 & anf.4 & anf.5 & anf.6 & anf.1 & anf.2 & anf.3 & anf.4 & anf.5 & anf.6 & $\begin{array}{l}\text { anf.1 } \\
\text { ac. }\end{array}$ & $\begin{array}{c}\text { anf.2 } \\
\text { ac. }\end{array}$ & $\begin{array}{c}\text { anf.3 } \\
\text { ac. }\end{array}$ & anf.4 & anf.5 \\
\hline $\mathrm{SiO}_{2}$ & 49.38 & 50.69 & 49.58 & 49.86 & 50.73 & 50.86 & 42.83 & 43.04 & 43.35 & 42.34 & 42.29 & 43.07 & 50.01 & 49.05 & 46.12 & 41.20 & 40.61 \\
\hline $\mathrm{TiO}_{2}$ & 0.23 & 0.15 & 0.36 & 0.20 & 0.28 & 0.24 & 0.17 & 0.27 & 0.27 & 0.29 & 0.23 & 0.31 & 0.08 & 0.12 & 0.16 & 0.57 & 0.39 \\
\hline $\mathrm{Al}_{2} \mathrm{O}_{3}$ & 6.79 & 5.88 & 6.79 & 6.12 & 5.68 & 5.75 & 11.37 & 9.11 & 10.21 & 11.46 & 11.43 & 10.99 & 1.93 & 3.29 & 5.28 & 11.77 & 12.48 \\
\hline $\mathrm{FeO}$ & 12.67 & 12.16 & 12.45 & 12.71 & 12.81 & 12.40 & 19.37 & 20.93 & 20.01 & 19.85 & 20.17 & 20.05 & 24.93 & 26.43 & 27.30 & 24.67 & 25.37 \\
\hline $\mathrm{MnO}$ & 0.82 & 0.96 & 1.09 & 0.96 & 0.93 & 0.91 & 1.29 & 1.21 & 1.23 & 1.20 & 1.17 & 1.07 & 0.81 & 0.74 & 0.71 & 0.96 & 0.70 \\
\hline $\mathrm{MgO}$ & 14.40 & 14.87 & 14.43 & 14.68 & 14.79 & 15.14 & 7.93 & 7.32 & 8.33 & 8.30 & 8.28 & 8.13 & 7.88 & 6.59 & 5.79 & 4.64 & 3.91 \\
\hline $\mathrm{CaO}$ & 11.83 & 12.12 & 12.00 & 12.12 & 12.27 & 11.79 & 11.53 & 11.00 & 11.70 & 11.75 & 11.51 & 11.70 & 11.85 & 11.56 & 11.44 & 11.56 & 11.49 \\
\hline $\mathrm{Na}_{2} \mathrm{O}$ & 1.11 & 0.80 & 0.99 & 0.82 & 0.86 & 0.92 & 1.39 & 1.11 & 1.09 & 1.36 & 1.37 & 1.34 & 0.27 & 0.32 & 0.52 & 1.39 & 1.16 \\
\hline $\mathrm{K}_{2} \mathrm{O}$ & 0.54 & 0.52 & 0.53 & 0.66 & 0.40 & 0.48 & 1.57 & 1.25 & 1.31 & 1.49 & 1.35 & 1.37 & 0.13 & 0.21 & 0.27 & 1.28 & 1.16 \\
\hline $\mathrm{F}$ & 0.91 & 0.92 & 0.83 & 0.86 & 0.75 & 0.93 & 1.21 & 0.80 & 0.97 & 1.29 & 1.04 & 1.21 & 0.22 & 0.04 & 0.19 & 0.68 & 0.35 \\
\hline $\mathrm{H}_{2} \mathrm{O}^{*}$ & 1.65 & 1.66 & 1.70 & 1.68 & 1.75 & 1.67 & 1.40 & 1.55 & 1.52 & 1.37 & 1.50 & 1.41 & 1.87 & 1.95 & 1.86 & 1.61 & 1.76 \\
\hline $\mathrm{O}=\mathrm{F}$ & 0.38 & 0.39 & 0.35 & 0.36 & 0.31 & 0.39 & 0.51 & 0.34 & 0.41 & 0.54 & 0.44 & 0.51 & 0.09 & 0.02 & 0.08 & 0.29 & 0.15 \\
\hline Total & 99.96 & 100.34 & 100.39 & 100.31 & 100.93 & 100.69 & 99.55 & 97.25 & 99.58 & 100.16 & 99.90 & 100.14 & 99.89 & 100.28 & 99.55 & 100.05 & 99.22 \\
\hline
\end{tabular}


Fórmula calculada na base de 23 oxigênios

\begin{tabular}{|c|c|c|c|c|c|c|c|c|c|c|c|c|c|c|c|c|c|}
\hline & \multirow{2}{*}{\multicolumn{6}{|c|}{ ZONA 2}} & & & & & & & & & & & \\
\hline & & & & & & & \multicolumn{6}{|c|}{ ZONA 1} & \multicolumn{5}{|c|}{ ZONA H } \\
\hline & anf.1 & anf.2 & anf.3 & anf.4 & anf.5 & anf.6 & anf.1 & anf.2 & anf.3 & anf.4 & anf.5 & anf.6 & ac. & ac. & ac. & anf.4 & anf.5 \\
\hline $\mathrm{Si}$ & 7.108 & 7.251 & 7.107 & 7.159 & 7.232 & 7.225 & 6.514 & 6.706 & 6.570 & 6.397 & 6.383 & 6.507 & 7.592 & 7.453 & 7.094 & 6.387 & 6.341 \\
\hline Al iv & 0.892 & 0.749 & 0.893 & 0.841 & 0.768 & 0.775 & 1.486 & 1.294 & 1.430 & 1.603 & 1.617 & 1.493 & 0.346 & 0.547 & 0.906 & 1.613 & 1.659 \\
\hline Al vi & 0.259 & 0.242 & 0.253 & 0.194 & 0.187 & 0.187 & 0.553 & 0.379 & 0.394 & 0.437 & 0.417 & 0.464 & 0.000 & 0.042 & 0.050 & 0.537 & 0.638 \\
\hline $\mathrm{Ti}$ & 0.025 & 0.016 & 0.039 & 0.022 & 0.030 & 0.025 & 0.019 & 0.032 & 0.031 & 0.033 & 0.026 & 0.035 & 0.009 & 0.013 & 0.019 & 0.066 & 0.046 \\
\hline $\mathrm{Cr}$ & 0.000 & 0.000 & 0.000 & 0.000 & 0.000 & 0.000 & 0.000 & 0.000 & 0.000 & 0.000 & 0.000 & 0.000 & 0.000 & 0.000 & 0.000 & 0.000 & 0.000 \\
\hline $\mathrm{Fe}^{3+}$ & 0.523 & 0.442 & 0.505 & 0.524 & 0.464 & 0.610 & 0.422 & 0.590 & 0.599 & 0.610 & 0.764 & 0.516 & 0.495 & 0.579 & 0.840 & 0.433 & 0.502 \\
\hline $\mathrm{Fe}^{2+}$ & 1.002 & 1.012 & 0.987 & 1.001 & 1.064 & 0.863 & 2.042 & 2.137 & 1.937 & 1.897 & 1.782 & 2.018 & 2.671 & 2.779 & 2.671 & 2.766 & 2.810 \\
\hline $\mathrm{Mn}$ & 0.100 & 0.116 & 0.132 & 0.117 & 0.113 & 0.109 & 0.166 & 0.159 & 0.158 & 0.154 & 0.149 & 0.137 & 0.105 & 0.095 & 0.092 & 0.126 & 0.093 \\
\hline $\mathrm{Mg}$ & 3.090 & 3.171 & 3.083 & 3.141 & 3.143 & 3.206 & 1.798 & 1.701 & 1.882 & 1.869 & 1.862 & 1.830 & 1.783 & 1.492 & 1.328 & 1.072 & 0.911 \\
\hline $\mathrm{Ca}$ & 1.825 & 1.857 & 1.843 & 1.864 & 1.874 & 1.795 & 1.879 & 1.837 & 1.901 & 1.902 & 1.861 & 1.894 & 1.927 & 1.882 & 1.886 & 1.920 & 1.922 \\
\hline $\mathrm{Na}$ & 0.310 & 0.222 & 0.275 & 0.229 & 0.237 & 0.252 & 0.410 & 0.336 & 0.321 & 0.399 & 0.402 & 0.391 & 0.078 & 0.095 & 0.154 & 0.418 & 0.352 \\
\hline $\mathrm{K}$ & 0.100 & 0.095 & 0.096 & 0.121 & 0.073 & 0.087 & 0.305 & 0.249 & 0.254 & 0.288 & 0.259 & 0.264 & 0.025 & 0.041 & 0.053 & 0.253 & 0.230 \\
\hline$F$ & 0.416 & 0.414 & 0.374 & 0.392 & 0.336 & 0.417 & 0.582 & 0.393 & 0.467 & 0.618 & 0.495 & 0.578 & 0.106 & 0.019 & 0.094 & 0.333 & 0.171 \\
\hline $\mathrm{OH}^{*}$ & 1.584 & 1.586 & 1.626 & 1.608 & 1.664 & 1.583 & 1.418 & 1.607 & 1.533 & 1.382 & 1.505 & 1.422 & 1.894 & 1.981 & 1.906 & 1.667 & 1.829 \\
\hline
\end{tabular}


CLINOPIROXÊNIO 


\begin{tabular}{|c|c|c|c|c|c|c|c|c|c|c|}
\hline & \multicolumn{10}{|c|}{ ZONA 1} \\
\hline & cpx.1 & cpx.2 & cpx.3 & cpx.1b & $c p x .2 b$ & cpx.4 & cpx.5 & cpx.6 & cpx.7 & cpx.8 \\
\hline $\mathrm{SiO}_{2}$ & 50.89 & 51.12 & 51.09 & 50.79 & 50.90 & 52.13 & 51.57 & 50.97 & 50.96 & 51.25 \\
\hline $\mathrm{TiO}_{2}$ & 0.12 & 0.13 & 0.18 & 0.00 & 0.08 & 0.08 & 0.11 & 0.03 & 0.04 & 0.05 \\
\hline $\mathrm{Al}_{2} \mathrm{O}_{3}$ & 0.55 & 0.52 & 0.35 & 0.58 & 0.20 & 0.38 & 0.29 & 0.43 & 0.48 & 0.48 \\
\hline $\mathrm{FeO}$ & 15.99 & 15.80 & 15.42 & 16.09 & 15.35 & 15.47 & 15.12 & 15.53 & 15.48 & 15.71 \\
\hline $\mathrm{MnO}$ & 1.62 & 1.90 & 1.58 & 1.68 & 1.63 & 1.61 & 1.72 & 1.63 & 1.75 & 1.62 \\
\hline $\mathrm{MgO}$ & 8.02 & 7.90 & 7.99 & 7.75 & 8.10 & 7.89 & 8.29 & 8.27 & 8.33 & 8.30 \\
\hline $\mathrm{CaO}$ & 22.96 & 22.96 & 23.08 & 22.02 & 23.13 & 23.10 & 24.04 & 23.13 & 23.46 & 22.92 \\
\hline $\mathrm{Na}_{2} \mathrm{O}$ & 0.16 & 0.14 & 0.12 & 0.12 & 0.12 & 0.13 & 0.09 & 0.17 & 0.14 & 0.14 \\
\hline Total & 100.31 & 100.47 & 99.80 & 99.03 & 99.51 & 100.79 & 101.21 & 100.17 & 100.64 & 100.47 \\
\hline \multicolumn{11}{|c|}{ Fórmula calculada na base de 6 oxigênios } \\
\hline Si & 1.978 & 1.983 & 1.990 & 1.995 & 1.990 & 2.005 & 1.982 & 1.981 & 1.973 & 1.984 \\
\hline $\mathrm{Ti}$ & 0.004 & 0.004 & 0.005 & 0.000 & 0.002 & 0.002 & 0.003 & 0.001 & 0.001 & 0.002 \\
\hline Al & 0.025 & 0.024 & 0.016 & 0.027 & 0.009 & 0.017 & 0.013 & 0.020 & 0.022 & 0.022 \\
\hline $\mathrm{Fe}$ & 0.520 & 0.512 & 0.502 & 0.529 & 0.502 & 0.498 & 0.486 & 0.505 & 0.501 & 0.509 \\
\hline $\mathrm{Mn}$ & 0.053 & 0.062 & 0.052 & 0.056 & 0.054 & 0.052 & 0.056 & 0.054 & 0.057 & 0.053 \\
\hline $\mathrm{Mg}$ & 0.465 & 0.457 & 0.464 & 0.454 & 0.472 & 0.452 & 0.475 & 0.479 & 0.481 & 0.479 \\
\hline $\mathrm{Ca}$ & 0.956 & 0.954 & 0.963 & 0.927 & 0.969 & 0.952 & 0.990 & 0.963 & 0.973 & 0.951 \\
\hline $\mathrm{Na}$ & 0.012 & 0.011 & 0.009 & 0.009 & 0.009 & 0.010 & 0.007 & 0.013 & 0.010 & 0.011 \\
\hline
\end{tabular}




\begin{tabular}{|c|c|c|c|c|c|c|c|c|c|c|c|c|}
\hline & \multicolumn{8}{|c|}{ ZONA 1A } & \multicolumn{4}{|c|}{ ZONA H } \\
\hline & cpx.1 & $\mathrm{cpx} .2$ & cpx.3 & $\mathrm{cpx} .4$ & cpx.5 & срх.6 & cpx.7 & cpx. 8 & срх.1 & cpx.2 & cpx.3 & cpx.4 \\
\hline $\mathrm{SiO}_{2}$ & 52.57 & 51.66 & 52.55 & 52.53 & 52.47 & 51.92 & 52.15 & 52.68 & 49.45 & 50.33 & 49.44 & 49.75 \\
\hline $\mathrm{TiO}_{2}$ & 0.01 & 0.12 & 0.01 & 0.00 & 0.00 & 0.00 & 0.04 & 0.04 & 0.11 & 0.17 & 0.06 & 0.04 \\
\hline $\mathrm{Al}_{2} \mathrm{O}_{3}$ & 0.18 & 0.24 & 0.41 & 0.50 & 0.42 & 0.60 & 0.27 & 0.30 & 0.67 & 0.50 & 0.72 & 0.62 \\
\hline $\mathrm{FeO}$ & 12.13 & 11.84 & 12.20 & 12.31 & 12.10 & 13.38 & 12.18 & 11.94 & 20.74 & 19.07 & 22.81 & 21.09 \\
\hline $\mathrm{MnO}$ & 1.25 & 1.22 & 1.27 & 1.28 & 1.34 & 1.29 & 1.33 & 1.26 & 1.09 & 1.30 & 1.40 & 1.36 \\
\hline MgO & 10.02 & 10.01 & 10.31 & 10.60 & 10.57 & 10.20 & 10.79 & 11.05 & 4.90 & 5.88 & 3.79 & 4.74 \\
\hline $\mathrm{CaO}$ & 23.39 & 23.51 & 23.87 & 23.42 & 23.69 & 23.22 & 23.66 & 23.33 & 22.12 & 22.64 & 21.59 & 22.39 \\
\hline $\mathrm{Na}_{2} \mathrm{O}$ & 0.07 & 0.13 & 0.19 & 0.21 & 0.21 & 0.32 & 0.17 & 0.17 & 0.15 & 0.18 & 0.21 & 0.22 \\
\hline Total & 99.62 & 98.72 & 100.81 & 100.85 & 100.80 & 100.91 & 100.59 & 100.77 & 99.23 & 100.07 & 100.03 & 100.22 \\
\hline \multicolumn{13}{|c|}{ Fórmula calculada na base de 6 oxigênios } \\
\hline $\mathrm{Si}$ & 1.978 & 1.983 & 1.990 & 1.995 & 1.990 & 2.005 & 1.982 & 1.981 & 1.973 & 1.984 & 1.984 & 1.981 \\
\hline $\mathrm{Ti}$ & 0.004 & 0.004 & 0.005 & 0.000 & 0.002 & 0.002 & 0.003 & 0.001 & 0.001 & 0.002 & 0.002 & 0.001 \\
\hline Al & 0.025 & 0.024 & 0.016 & 0.027 & 0.009 & 0.017 & 0.013 & 0.020 & 0.022 & 0.022 & 0.034 & 0.029 \\
\hline $\mathrm{Fe}$ & 0.520 & 0.512 & 0.502 & 0.529 & 0.502 & 0.498 & 0.486 & 0.505 & 0.501 & 0.509 & 0.765 & 0.702 \\
\hline $\mathrm{Mn}$ & 0.053 & 0.062 & 0.052 & 0.056 & 0.054 & 0.052 & 0.056 & 0.054 & 0.057 & 0.053 & 0.048 & 0.046 \\
\hline $\mathrm{Mg}$ & 0.465 & 0.457 & 0.464 & 0.454 & 0.472 & 0.452 & 0.475 & 0.479 & 0.481 & 0.479 & 0.227 & 0.281 \\
\hline $\mathrm{Ca}$ & 0.956 & 0.954 & 0.963 & 0.927 & 0.969 & 0.952 & 0.990 & 0.963 & 0.973 & 0.951 & 0.928 & 0.955 \\
\hline $\mathrm{Na}$ & 0.012 & 0.011 & 0.009 & 0.009 & 0.009 & 0.010 & 0.007 & 0.013 & 0.010 & 0.011 & 0.017 & 0.017 \\
\hline
\end{tabular}


TITANITA 


\begin{tabular}{|c|c|c|c|c|c|c|c|c|c|c|c|c|c|}
\hline & \multicolumn{6}{|c|}{ ZONA 3} & \multicolumn{7}{|c|}{ ZONA 2} \\
\hline & Z3_Htit4 & Z3_Htit5 & Z3_Htit6 & Z3_tit7 & Z3_tit8 & Z3_tit9 & Z2_Htit1 & Z2_Htit2 & Z2_Htit3 & Z2_tit4 & Z2_tit5 & Z2_tit6 & Z2_tit7 \\
\hline $\mathrm{SiO}_{2}$ & 30.43 & 30.51 & 30.13 & 30.93 & 31.14 & 31.07 & 30.67 & 30.91 & 31.07 & 30.91 & 31.01 & 31.16 & 31.20 \\
\hline $\mathrm{TiO}_{2}$ & 36.89 & 34.45 & 37.25 & 33.40 & 33.40 & 34.18 & 37.11 & 34.70 & 33.62 & 33.14 & 34.03 & 33.72 & 33.39 \\
\hline $\mathrm{Al}_{2} \mathrm{O}_{3}$ & 2.69 & 3.65 & 1.87 & 4.09 & 3.97 & 3.60 & 3.96 & 4.00 & 3.28 & 4.37 & 3.98 & 3.66 & 4.33 \\
\hline $\mathrm{FeO}$ & 0.65 & 0.72 & 0.77 & 0.79 & 0.72 & 0.76 & 0.80 & 0.71 & 0.87 & 0.78 & 0.65 & 0.77 & 0.43 \\
\hline $\mathrm{MnO}$ & 0.22 & 0.15 & 0.13 & 0.21 & 0.06 & 0.05 & 0.00 & 0.20 & 0.15 & 0.08 & 0.09 & 0.03 & 0.18 \\
\hline $\mathrm{MgO}$ & 0.01 & 0.11 & 0.04 & 0.07 & 0.10 & 0.09 & 0.10 & 0.17 & 0.56 & 0.15 & 0.12 & 0.09 & 0.08 \\
\hline $\mathrm{Na}_{2} \mathrm{O}$ & 0.11 & 0.04 & 0.08 & 0.05 & 0.08 & 0.08 & 0.01 & 0.07 & 0.04 & 0.11 & 0.05 & 0.06 & 0.05 \\
\hline $\mathrm{CaO}$ & 27.98 & 27.77 & 27.59 & 27.73 & 28.28 & 27.88 & 27.97 & 27.47 & 27.38 & 27.77 & 27.92 & 27.98 & 28.08 \\
\hline $\mathrm{F}$ & 0.86 & 1.57 & 0.49 & 1.46 & 1.37 & 1.29 & 1.43 & 1.46 & 1.35 & 1.58 & 1.41 & 1.23 & 1.46 \\
\hline $\mathrm{O}=\mathrm{H}$ & 0.36 & 0.66 & 0.21 & 0.62 & 0.58 & 0.54 & 0.60 & 0.61 & 0.57 & 0.67 & 0.59 & 0.52 & 0.62 \\
\hline Total & 99.47 & 98.31 & 98.15 & 98.12 & 98.54 & 98.46 & 101.44 & 99.07 & 97.75 & 98.23 & 98.67 & 98.17 & 98.57 \\
\hline \multicolumn{14}{|c|}{ Fórmula calculada na base de 5 oxigênios } \\
\hline $\mathrm{Si}$ & 0.993 & 1.001 & 0.999 & 1.014 & 1.017 & 1.016 & 0.976 & 1.004 & 1.024 & 1.011 & 1.011 & 1.022 & 1.017 \\
\hline $\mathrm{Ti}$ & 0.905 & 0.850 & 0.929 & 0.823 & 0.820 & 0.840 & 0.888 & 0.848 & 0.833 & 0.815 & 0.834 & 0.831 & 0.818 \\
\hline Al & 0.103 & 0.141 & 0.073 & 0.158 & 0.153 & 0.139 & 0.148 & 0.153 & 0.127 & 0.169 & 0.153 & 0.141 & 0.166 \\
\hline $\mathrm{Fe}$ & 0.018 & 0.020 & 0.021 & 0.029 & 0.027 & 0.028 & 0.021 & 0.019 & 0.024 & 0.029 & 0.024 & 0.029 & 0.016 \\
\hline $\mathrm{Mn}$ & 0.006 & 0.004 & 0.004 & 0.006 & 0.002 & 0.001 & 0.000 & 0.005 & 0.004 & 0.002 & 0.002 & 0.001 & 0.005 \\
\hline $\mathrm{Mg}$ & 0.001 & 0.005 & 0.002 & 0.004 & 0.005 & 0.004 & 0.005 & 0.008 & 0.027 & 0.007 & 0.006 & 0.004 & 0.004 \\
\hline $\mathrm{Na}$ & 0.007 & 0.003 & 0.005 & 0.003 & 0.005 & 0.005 & 0.001 & 0.004 & 0.002 & 0.007 & 0.003 & 0.004 & 0.003 \\
\hline $\mathrm{Ca}$ & 0.978 & 0.976 & 0.980 & 0.973 & 0.989 & 0.976 & 0.953 & 0.956 & 0.967 & 0.973 & 0.975 & 0.983 & 0.980 \\
\hline $\mathrm{F}$ & 0.088 & 0.162 & 0.052 & 0.152 & 0.142 & 0.134 & 0.144 & 0.149 & 0.141 & 0.164 & 0.145 & 0.128 & 0.151 \\
\hline
\end{tabular}




\begin{tabular}{|c|c|c|c|c|c|c|c|c|c|c|}
\hline & \multicolumn{7}{|c|}{ ZONA 1} & \multicolumn{3}{|c|}{ ZONA 1A } \\
\hline & Z1_Htit1 & Z1_Htit2 & Z1_Htit3 & Z1_tit4 & Z1_tit5 & Z1_tit6 & Z1_tit7 & Z1A_Htit1 & Z1A_Htit2 & Z1A_Htit3 \\
\hline $\mathrm{SiO}_{2}$ & 31.53 & 31.33 & 31.57 & 31.16 & 31.63 & 31.20 & 31.27 & 31.23 & 31.43 & 31.09 \\
\hline $\mathrm{TiO}_{2}$ & 26.18 & 27.42 & 26.41 & 27.53 & 26.35 & 26.76 & 27.33 & 27.11 & 26.73 & 26.32 \\
\hline $\mathrm{Al}_{2} \mathrm{O}_{3}$ & 8.86 & 8.50 & 8.69 & 8.42 & 9.25 & 8.72 & 8.23 & 8.25 & 7.60 & 9.06 \\
\hline $\mathrm{FeO}$ & 0.48 & 0.58 & 0.61 & 0.69 & 0.58 & 0.46 & 0.72 & 0.45 & 0.52 & 0.46 \\
\hline $\mathrm{MnO}$ & 0.13 & 0.13 & 0.07 & 0.27 & 0.17 & 0.19 & 0.19 & 0.19 & 0.25 & 0.30 \\
\hline $\mathrm{MgO}$ & 0.08 & 0.10 & 0.09 & 0.12 & 0.10 & 0.10 & 0.10 & 0.14 & 0.14 & 0.12 \\
\hline $\mathrm{Na}_{2} \mathrm{O}$ & 0.00 & 0.00 & 0.03 & 0.01 & 0.05 & 0.03 & 0.01 & 0.03 & 0.07 & 0.06 \\
\hline $\mathrm{CaO}$ & 28.50 & 28.65 & 28.29 & 28.75 & 28.40 & 28.65 & 28.33 & 28.05 & 28.27 & 28.02 \\
\hline$F$ & 3.27 & 2.99 & 3.08 & 3.04 & 3.02 & 3.13 & 2.84 & 3.16 & 2.75 & 3.28 \\
\hline $\mathrm{O}=\mathrm{H}$ & 1.38 & 1.26 & 1.30 & 1.28 & 1.27 & 1.32 & 1.20 & 1.33 & 1.16 & 1.38 \\
\hline Total & 97.65 & 98.44 & 97.53 & 98.70 & 98.26 & 97.91 & 97.83 & 97.27 & 96.60 & 97.34 \\
\hline \multicolumn{11}{|c|}{ Fórmula calculada na base de 5 oxigênios } \\
\hline $\mathrm{Si}$ & 1.021 & 1.010 & 1.024 & 1.002 & 1.017 & 1.009 & 1.014 & 1.016 & 1.033 & 1.010 \\
\hline $\mathrm{Ti}$ & 0.637 & 0.665 & 0.644 & 0.666 & 0.637 & 0.651 & 0.667 & 0.664 & 0.661 & 0.643 \\
\hline Al & 0.338 & 0.323 & 0.332 & 0.319 & 0.351 & 0.332 & 0.315 & 0.316 & 0.295 & 0.347 \\
\hline $\mathrm{Fe}$ & 0.013 & 0.016 & 0.017 & 0.025 & 0.021 & 0.017 & 0.026 & 0.012 & 0.014 & 0.013 \\
\hline $\mathrm{Mn}$ & 0.004 & 0.004 & 0.002 & 0.007 & 0.005 & 0.005 & 0.005 & 0.005 & 0.007 & 0.008 \\
\hline $\mathrm{Mg}$ & 0.004 & 0.005 & 0.004 & 0.006 & 0.005 & 0.005 & 0.005 & 0.007 & 0.007 & 0.006 \\
\hline $\mathrm{Na}$ & 0.000 & 0.000 & 0.002 & 0.000 & 0.003 & 0.002 & 0.001 & 0.002 & 0.004 & 0.004 \\
\hline $\mathrm{Ca}$ & 0.989 & 0.990 & 0.983 & 0.991 & 0.979 & 0.993 & 0.984 & 0.978 & 0.996 & 0.975 \\
\hline $\mathrm{F}$ & 0.335 & 0.305 & 0.316 & 0.309 & 0.307 & 0.320 & 0.291 & 0.325 & 0.286 & 0.337 \\
\hline
\end{tabular}




\begin{tabular}{|c|c|c|c|c|c|c|c|c|c|c|}
\hline & \multicolumn{6}{|c|}{ ZONA 1A } & \multicolumn{4}{|c|}{ ZONA H } \\
\hline & Z1A_tit4 & Z1A_tit5 & Z1A_tit6 & Z1A_tit7 & Z1A_tit8 & Z1A_tit9 & ZH_Htit1 & ZH_Htit2 & ZH_tit3 & ZH_tit4 \\
\hline $\mathrm{SiO}_{2}$ & 31.03 & 31.40 & 31.38 & 31.36 & 31.34 & 31.49 & 31.03 & 30.66 & 31.34 & 31.21 \\
\hline $\mathrm{TiO}_{2}$ & 26.85 & 26.93 & 26.11 & 27.02 & 26.78 & 27.11 & 31.31 & 32.97 & 28.83 & 29.81 \\
\hline $\mathrm{Al}_{2} \mathrm{O}_{3}$ & 8.55 & 8.69 & 8.94 & 8.38 & 8.99 & 8.94 & 6.36 & 3.86 & 7.27 & 6.68 \\
\hline $\mathrm{FeO}$ & 0.59 & 0.59 & 0.54 & 0.55 & 0.47 & 0.42 & 1.01 & 2.16 & 0.85 & 1.00 \\
\hline $\mathrm{MnO}$ & 0.08 & 0.17 & 0.16 & 0.13 & 0.16 & 0.15 & 0.30 & 0.27 & 0.08 & 0.15 \\
\hline $\mathrm{MgO}$ & 0.13 & 0.14 & 0.20 & 0.18 & 0.14 & 0.17 & 0.06 & 0.09 & 0.05 & 0.05 \\
\hline $\mathrm{Na}_{2} \mathrm{O}$ & 0.01 & 0.02 & 0.01 & 0.01 & 0.00 & 0.00 & 0.06 & 0.00 & 0.03 & 0.02 \\
\hline $\mathrm{CaO}$ & 28.37 & 28.44 & 28.30 & 27.64 & 28.21 & 28.16 & 27.68 & 27.26 & 28.10 & 28.03 \\
\hline $\mathrm{F}$ & 2.94 & 3.24 & 3.38 & 3.05 & 3.10 & 3.12 & 2.12 & 1.65 & 2.55 & 2.34 \\
\hline $\mathrm{O}=\mathrm{H}$ & 1.24 & 1.36 & 1.42 & 1.28 & 1.30 & 1.31 & 0.89 & 0.69 & 1.07 & 0.98 \\
\hline Total & 97.31 & 98.24 & 97.59 & 97.03 & 97.88 & 98.25 & 99.03 & 98.22 & 98.03 & 98.29 \\
\hline \multicolumn{11}{|c|}{ Fórmula calculada na base de 5 oxigênios } \\
\hline $\mathrm{Si}$ & 1.010 & 1.011 & 1.015 & 1.021 & 1.012 & 1.012 & 1.003 & 1.010 & 1.016 & 1.012 \\
\hline $\mathrm{Ti}$ & 0.658 & 0.652 & 0.635 & 0.662 & 0.650 & 0.656 & 0.761 & 0.817 & 0.703 & 0.727 \\
\hline Al & 0.328 & 0.330 & 0.341 & 0.321 & 0.342 & 0.339 & 0.242 & 0.150 & 0.278 & 0.255 \\
\hline $\mathrm{Fe}$ & 0.022 & 0.021 & 0.020 & 0.020 & 0.017 & 0.015 & 0.027 & 0.059 & 0.031 & 0.036 \\
\hline $\mathrm{Mn}$ & 0.002 & 0.005 & 0.004 & 0.004 & 0.004 & 0.004 & 0.008 & 0.008 & 0.002 & 0.004 \\
\hline $\mathrm{Mg}$ & 0.006 & 0.007 & 0.010 & 0.009 & 0.007 & 0.008 & 0.003 & 0.004 & 0.003 & 0.002 \\
\hline $\mathrm{Na}$ & 0.001 & 0.001 & 0.001 & 0.001 & 0.000 & 0.000 & 0.004 & 0.000 & 0.002 & 0.001 \\
\hline $\mathrm{Ca}$ & 0.990 & 0.981 & 0.981 & 0.964 & 0.976 & 0.970 & 0.959 & 0.963 & 0.976 & 0.974 \\
\hline $\mathrm{F}$ & 0.303 & 0.330 & 0.345 & 0.314 & 0.316 & 0.317 & 0.217 & 0.172 & 0.262 & 0.240 \\
\hline
\end{tabular}


GRANADA 


\begin{tabular}{|c|c|c|c|c|c|c|c|c|c|c|}
\hline & \multicolumn{10}{|c|}{ Pegmatito simples "16" } \\
\hline & 16g1 & 16g2 & $16 \mathrm{~g} 3$ & $16 \mathrm{~g} 4$ & $16 \mathrm{~g} 5$ & $16 \mathrm{~g} 6$ & $16 \mathrm{~g} 7$ & 16g8 & $16 \mathrm{~g} 9$ & $16 \mathrm{~g} 10$ \\
\hline $\mathrm{SiO} 2$ & 34.93 & 35.29 & 34.23 & 33.98 & 34.71 & 34.59 & 34.90 & 34.65 & 34.30 & 34.99 \\
\hline $\mathrm{TiO} 2$ & 0.05 & 0.03 & 0.00 & 0.00 & 0.13 & 0.00 & 0.00 & 0.08 & 0.00 & 0.08 \\
\hline Al2O3 & 20.68 & 20.59 & 20.70 & 20.85 & 20.67 & 20.85 & 20.69 & 20.77 & 20.92 & 20.68 \\
\hline FeOt & 31.83 & 31.45 & 32.24 & 32.04 & 33.20 & 31.63 & 31.74 & 31.85 & 33.25 & 32.42 \\
\hline $\mathrm{MnO}$ & 11.58 & 11.93 & 11.55 & 11.27 & 10.35 & 11.64 & 11.30 & 11.33 & 10.14 & 11.17 \\
\hline $\mathrm{MgO}$ & 0.16 & 0.20 & 0.21 & 0.18 & 0.16 & 0.20 & 0.16 & 0.18 & 0.24 & 0.15 \\
\hline $\mathrm{CaO}$ & 0.23 & 0.20 & 0.25 & 0.20 & 0.20 & 0.26 & 0.20 & 0.24 & 0.27 & 0.22 \\
\hline \multirow[t]{2}{*}{ Total } & 99.51 & 99.73 & 99.27 & 98.58 & 99.47 & 99.21 & 99.04 & 99.14 & 99.18 & 99.77 \\
\hline & \multicolumn{10}{|c|}{ Fórmula calculada na base de 12 oxigênios } \\
\hline Si & 2.919 & 2.938 & 2.878 & 2.874 & 2.905 & 2.900 & 2.927 & 2.906 & 2.881 & 2.918 \\
\hline Al iv & 0.081 & 0.062 & 0.122 & 0.126 & 0.095 & 0.100 & 0.073 & 0.094 & 0.119 & 0.082 \\
\hline Al vi & 1.958 & 1.961 & 1.934 & 1.956 & 1.948 & 1.964 & 1.974 & 1.962 & 1.956 & 1.953 \\
\hline $\mathrm{Ti}$ & 0.003 & 0.002 & 0.000 & 0.000 & 0.008 & 0.000 & 0.000 & 0.005 & 0.000 & 0.005 \\
\hline $\mathrm{Fe} 3+$ & 0.035 & 0.033 & 0.059 & 0.039 & 0.039 & 0.032 & 0.023 & 0.029 & 0.040 & 0.037 \\
\hline $\mathrm{Fe} 2+$ & 2.190 & 2.157 & 2.208 & 2.227 & 2.284 & 2.186 & 2.203 & 2.205 & 2.296 & 2.223 \\
\hline $\mathrm{Mn}$ & 0.819 & 0.841 & 0.823 & 0.808 & 0.734 & 0.826 & 0.803 & 0.805 & 0.722 & 0.789 \\
\hline $\mathrm{Mg}$ & 0.020 & 0.025 & 0.026 & 0.023 & 0.019 & 0.024 & 0.020 & 0.022 & 0.030 & 0.019 \\
\hline $\mathrm{Ca}$ & 0.021 & 0.018 & 0.023 & 0.018 & 0.018 & 0.024 & 0.018 & 0.021 & 0.025 & 0.019 \\
\hline Almandina & 70.52 & 69.92 & 69.72 & 70.49 & 73.45 & 69.85 & 71.27 & 70.81 & 73.06 & 71.66 \\
\hline Andradita & 0.71 & 0.61 & 0.79 & 0.62 & 0.63 & 0.81 & 0.61 & 0.74 & 0.85 & 0.66 \\
\hline Grossulária & 0.00 & 0.00 & 0.00 & 0.00 & 0.00 & 0.00 & 0.00 & 0.00 & 0.00 & 0.00 \\
\hline Piropo & 0.70 & 0.84 & 0.91 & 0.79 & 0.67 & 0.84 & 0.70 & 0.77 & 1.04 & 0.64 \\
\hline Espessartita & 28.07 & 28.63 & 28.58 & 28.10 & 25.26 & 28.49 & 27.42 & 27.69 & 25.04 & 27.04 \\
\hline $\mathrm{Mn} / \mathrm{Fe}$ & 0.27 & 0.28 & 0.27 & 0.27 & 0.24 & 0.27 & 0.27 & 0.27 & 0.24 & 0.26 \\
\hline
\end{tabular}




\begin{tabular}{cccccccccc}
\hline \multicolumn{7}{c}{ Pegmatito “16" } & \multicolumn{7}{c}{ Pegmatito simples “17” } \\
\hline SiO2 & $16 g 11$ & $16 g 12$ & $17 g 1$ & $17 g 2$ & $17 g 3$ & $17 g 4$ & $17 g 5$ & $17 g 6$ & $17 g 8$ \\
TiO2 & 35.44 & 35.00 & 34.68 & 34.65 & 35.71 & 34.99 & 35.04 & 35.04 & 34.37 \\
Al2O3 & 0.09 & 0.00 & 0.02 & 0.01 & 0.00 & 0.15 & 0.00 & 0.18 & 0.00 \\
FeOt & 20.45 & 20.88 & 20.63 & 20.46 & 20.57 & 20.61 & 20.68 & 20.92 & 20.46 \\
MnO & 33.01 & 31.35 & 34.76 & 34.41 & 34.50 & 34.41 & 33.66 & 34.05 & 34.33 \\
MgO & 10.35 & 11.78 & 7.72 & 8.02 & 7.61 & 8.27 & 8.50 & 7.67 & 8.43 \\
CaO & 0.18 & 0.19 & 0.49 & 0.56 & 0.44 & 0.43 & 0.42 & 0.49 & 0.43 \\
Total & 0.27 & 0.23 & 0.46 & 0.48 & 0.42 & 0.53 & 0.56 & 0.53 & 0.46 \\
\hline & 99.85 & 99.46 & 98.80 & 98.66 & 99.27 & 99.44 & 98.91 & 98.87 & 98.57 \\
\hline Si & 2.947 & 2.921 & 2.912 & 2.914 & 2.971 & 2.919 & 2.933 & 2.928 & 2.900 \\
Al iv & 0.053 & 0.079 & 0.088 & 0.086 & 0.029 & 0.081 & 0.067 & 0.072 & 0.100 \\
Al vi & 1.954 & 1.977 & 1.957 & 1.946 & 1.988 & 1.948 & 1.975 & 1.989 & 1.939 \\
Ti & 0.005 & 0.000 & 0.001 & 0.001 & 0.000 & 0.010 & 0.000 & 0.011 & 0.000 \\
Fe3+ & 0.036 & 0.020 & 0.037 & 0.047 & 0.010 & 0.038 & 0.022 & 0.000 & 0.054 \\
Fe2+ & 2.259 & 2.168 & 2.404 & 2.373 & 2.389 & 2.363 & 2.335 & 2.379 & 2.369 \\
Mn & 0.729 & 0.833 & 0.549 & 0.571 & 0.536 & 0.584 & 0.603 & 0.543 & 0.603 \\
Mg & 0.023 & 0.024 & 0.061 & 0.070 & 0.055 & 0.054 & 0.053 & 0.061 & 0.054 \\
Ca & 0.024 & 0.021 & 0.041 & 0.043 & 0.038 & 0.047 & 0.050 & 0.048 & 0.042 \\
Almandina & 73.66 & 69.97 & 77.66 & 76.49 & 78.84 & 76.52 & 75.93 & 77.76 & 75.91 \\
Andradita & 0.83 & 0.71 & 1.41 & 1.49 & 0.53 & 1.61 & 1.12 & 0.00 & 1.44 \\
Grossulária & 0.00 & 0.00 & 0.00 & 0.00 & 0.74 & 0.00 & 0.59 & 1.62 & 0.00 \\
Piropo & 0.77 & 0.82 & 2.09 & 2.41 & 1.84 & 1.84 & 1.80 & 2.07 & 1.87 \\
Espessartita & 24.74 & 28.50 & 18.85 & 19.61 & 18.05 & 20.02 & 20.56 & 18.54 & 20.78 \\
Mn/Fe & 0.24 & 0.28 & 0.19 & 0.19 & 0.18 & 0.20 & 0.21 & 0.19 & 0.20 \\
\hline
\end{tabular}




\begin{tabular}{|c|c|c|c|c|c|c|c|c|c|c|}
\hline & \multicolumn{10}{|c|}{ Leucogranito grosso Mata Azul } \\
\hline & 18g2 & $18 \mathrm{~g} 3$ & $18 \mathrm{~g} 4$ & $18 \mathrm{~g} 5$ & $18 \mathrm{~g} 6$ & $18 \mathrm{~g} 7$ & $18 \mathrm{~g} 8$ & $18 \mathrm{~g} 9$ & $18 \mathrm{~g} 10$ & $18 g 11$ \\
\hline $\mathrm{SiO} 2$ & 35.49 & 34.45 & 34.98 & 35.26 & 35.00 & 35.84 & 34.60 & 33.94 & 33.83 & 33.86 \\
\hline $\mathrm{TiO} 2$ & 0.23 & 0.02 & 0.10 & 0.00 & 0.00 & 0.03 & 0.07 & 0.20 & 0.00 & 0.00 \\
\hline $\mathrm{Al} 2 \mathrm{O} 3$ & 20.71 & 20.59 & 20.83 & 20.93 & 21.00 & 21.01 & 20.69 & 20.88 & 19.86 & 20.41 \\
\hline $\mathrm{FeOt}$ & 34.72 & 35.26 & 35.01 & 34.33 & 35.17 & 34.51 & 34.58 & 35.41 & 32.30 & 34.90 \\
\hline $\mathrm{MnO}$ & 6.66 & 6.71 & 6.70 & 6.68 & 6.26 & 6.65 & 6.19 & 6.05 & 6.20 & 6.93 \\
\hline $\mathrm{MgO}$ & 1.11 & 1.04 & 1.17 & 1.16 & 1.23 & 1.21 & 1.21 & 1.09 & 1.04 & 1.14 \\
\hline $\mathrm{CaO}$ & 0.42 & 0.44 & 0.38 & 0.51 & 0.39 & 0.45 & 0.46 & 0.43 & 0.56 & 0.46 \\
\hline Total & 99.36 & 98.60 & 99.23 & 98.88 & 99.08 & 99.72 & 97.85 & 98.06 & 93.78 & 97.81 \\
\hline & \multicolumn{10}{|c|}{ Fórmula calculada na base de 12 oxigênios } \\
\hline $\mathrm{Si}$ & 2.940 & 2.894 & 2.910 & 2.934 & 2.912 & 2.952 & 2.914 & 2.865 & 2.957 & 2.872 \\
\hline Al iv & 0.060 & 0.106 & 0.090 & 0.066 & 0.088 & 0.048 & 0.086 & 0.135 & 0.043 & 0.128 \\
\hline Al vi & 1.965 & 1.938 & 1.955 & 1.987 & 1.973 & 1.992 & 1.969 & 1.946 & 2.005 & 1.918 \\
\hline $\mathrm{Ti}$ & 0.014 & 0.001 & 0.007 & 0.000 & 0.000 & 0.002 & 0.005 & 0.013 & 0.000 & 0.000 \\
\hline $\mathrm{Fe} 3+$ & 0.019 & 0.054 & 0.034 & 0.011 & 0.024 & 0.005 & 0.023 & 0.037 & 0.000 & 0.073 \\
\hline $\mathrm{Fe} 2+$ & 2.387 & 2.423 & 2.402 & 2.377 & 2.424 & 2.372 & 2.412 & 2.463 & 2.368 & 2.403 \\
\hline $\mathrm{Mn}$ & 0.467 & 0.477 & 0.472 & 0.471 & 0.441 & 0.464 & 0.442 & 0.433 & 0.459 & 0.498 \\
\hline $\mathrm{Mg}$ & 0.137 & 0.130 & 0.145 & 0.143 & 0.152 & 0.149 & 0.152 & 0.137 & 0.135 & 0.144 \\
\hline $\mathrm{Ca}$ & 0.038 & 0.039 & 0.034 & 0.045 & 0.034 & 0.040 & 0.042 & 0.039 & 0.053 & 0.042 \\
\hline Almandina & 78.17 & 77.66 & 77.62 & 77.52 & 78.44 & 77.89 & 78.18 & 78.74 & 78.12 & 76.18 \\
\hline Andradita & 0.96 & 1.36 & 1.17 & 0.58 & 1.18 & 0.26 & 1.19 & 1.36 & 0.00 & 1.47 \\
\hline Grossulária & 0.32 & 0.00 & 0.00 & 0.96 & 0.00 & 1.10 & 0.25 & 0.00 & 1.78 & 0.00 \\
\hline Piropo & 4.66 & 4.49 & 4.99 & 4.89 & 5.23 & 5.03 & 5.23 & 4.80 & 4.57 & 5.02 \\
\hline Espessartita & 15.89 & 16.49 & 16.21 & 16.05 & 15.14 & 15.72 & 15.16 & 15.10 & 15.52 & 17.34 \\
\hline $\mathrm{Mn} / \mathrm{Fe}$ & 0.16 & 0.16 & 0.16 & 0.17 & 0.15 & 0.16 & 0.15 & 0.15 & 0.16 & 0.17 \\
\hline
\end{tabular}




\begin{tabular}{cccccccccc}
\hline & \multicolumn{10}{c}{ Pegmatito Onça } \\
\hline SiO2 & $08 g 1$ & $08 g 3$ & $08 g 4$ & $08 g 5$ & $08 g 6$ & $08 g 7$ & $08 g 8$ & $08 g 9$ & $08 g 10$ \\
TiO2 & 36.20 & 35.90 & 35.00 & 36.02 & 35.19 & 36.07 & 35.73 & 36.20 & 36.15 \\
Al2O3 & 0.09 & 0.00 & 0.06 & 0.12 & 0.12 & 0.00 & 0.06 & 0.19 & 0.00 \\
FeOt & 23.11 & 22.91 & 23.00 & 22.98 & 22.55 & 22.93 & 22.61 & 23.04 & 22.62 \\
MnO & 12.95 & 28.33 & 28.45 & 29.78 & 29.16 & 28.46 & 30.32 & 30.23 & 28.91 \\
MgO & 0.65 & 0.51 & 0.80 & 0.83 & 0.72 & 0.67 & 0.66 & 0.54 & 0.76 \\
CaO & 0.24 & 0.13 & 0.25 & 0.23 & 0.28 & 0.23 & 0.17 & 0.20 & 0.26 \\
Total & 102.27 & 101.43 & 100.74 & 101.67 & 100.05 & 101.39 & 100.27 & 102.55 & 101.10 \\
\hline & & & Fórmula calculada na base de 12 oxigênios & & \\
\hline Si & 2.878 & 2.882 & 2.838 & 2.878 & 2.868 & 2.888 & 2.892 & 2.877 & 2.904 \\
Al iv & 0.122 & 0.118 & 0.162 & 0.122 & 0.132 & 0.112 & 0.108 & 0.123 & 0.096 \\
Al vi & 2.059 & 2.064 & 2.049 & 2.057 & 2.047 & 2.068 & 2.066 & 2.049 & 2.061 \\
Ti & 0.005 & 0.000 & 0.003 & 0.007 & 0.007 & 0.000 & 0.003 & 0.011 & 0.000 \\
Fe3+ & 0.000 & 0.000 & 0.000 & 0.000 & 0.000 & 0.000 & 0.000 & 0.000 & 0.000 \\
Fe2+ & 2.016 & 1.986 & 1.997 & 2.074 & 2.058 & 1.995 & 2.143 & 2.088 & 2.021 \\
Mn & 0.870 & 0.928 & 0.905 & 0.793 & 0.831 & 0.883 & 0.735 & 0.819 & 0.844 \\
Mg & 0.077 & 0.061 & 0.097 & 0.098 & 0.087 & 0.080 & 0.080 & 0.064 & 0.091 \\
Ca & 0.021 & 0.011 & 0.021 & 0.020 & 0.024 & 0.020 & 0.015 & 0.017 & 0.022 \\
& & & & & & & & & \\
Almandina & 66.38 & 65.29 & 63.95 & 68.34 & 67.15 & 65.95 & 71.32 & 68.74 & 67.05 \\
Andradita & 0.00 & 0.00 & 0.00 & 0.00 & 0.00 & 0.00 & 0.00 & 0.00 & 0.00 \\
Grossulária & 0.72 & 0.39 & 0.75 & 0.68 & 0.84 & 0.68 & 0.52 & 0.58 & 0.76 \\
Piropo & 2.68 & 2.10 & 3.40 & 3.42 & 3.03 & 2.78 & 2.75 & 2.23 & 3.12 \\
Espessartita & 30.23 & 32.22 & 31.90 & 27.56 & 28.98 & 30.59 & 25.42 & 28.45 & 29.07 \\
Mn/Fe & 0.30 & 0.32 & 0.31 & 0.28 & 0.29 & 0.31 & 0.26 & 0.28 & 0.29 \\
\hline
\end{tabular}




\begin{tabular}{ccccccc}
\hline \multicolumn{7}{c}{ ZONA 3 Paragnaisse } \\
\hline SiO2 & $17 g r e 01$ & $17 g r e 02$ & $17 g r e 03$ & $17 g r e 04$ & $17 g r e 05$ & $17 g r e 06$ \\
TiO2 & 34.30 & 35.11 & 36.45 & 35.23 & 35.22 & 35.55 \\
Al2O3 & 0.03 & 0.12 & 0.00 & 0.00 & 0.05 & 0.06 \\
FeOt & 22.57 & 22.53 & 22.55 & 21.83 & 22.82 & 22.47 \\
MnO & 26.88 & 27.47 & 27.64 & 26.45 & 26.85 & 29.70 \\
MgO & 13.27 & 13.06 & 12.96 & 13.51 & 13.78 & 10.28 \\
CaO & 1.45 & 1.33 & 1.36 & 1.33 & 1.20 & 1.92 \\
Total & 0.71 & 0.72 & 0.74 & 0.87 & 0.89 & 0.32 \\
Si & 99.20 & 100.34 & 101.70 & 99.22 & 100.80 & 100.29 \\
\hline Al iv & 2.826 & 2.856 & 2.909 & 2.898 & 2.849 & 2.878 \\
Al vi & 0.174 & 0.144 & 0.091 & 0.102 & 0.151 & 0.122 \\
Ti & 2.025 & 2.024 & 2.040 & 2.020 & 2.035 & 2.030 \\
Fe3+ & 0.002 & 0.007 & 0.000 & 0.000 & 0.003 & 0.004 \\
Fe2+ & 0.000 & 0.000 & 0.000 & 0.000 & 0.000 & 0.000 \\
Mn & 1.888 & 1.909 & 1.898 & 1.847 & 1.866 & 2.056 \\
Mg & 0.926 & 0.900 & 0.876 & 0.941 & 0.944 & 0.705 \\
Ca & 0.178 & 0.162 & 0.162 & 0.163 & 0.144 & 0.232 \\
& 0.062 & 0.063 & 0.063 & 0.077 & 0.077 & 0.028 \\
Almandina & 58.71 & 60.64 & 62.14 & 59.26 & 59.09 & 66.49 \\
Andradita & 0.00 & 0.00 & 0.00 & 0.00 & 0.00 & 0.00 \\
Grossulária & 2.21 & 2.20 & 2.18 & 2.65 & 2.71 & 0.96 \\
Piropo & 6.30 & 5.66 & 5.55 & 5.61 & 5.06 & 8.06 \\
Espessartita & 32.78 & 31.50 & 30.13 & 32.47 & 33.14 & 24.49 \\
Mn/Fe & 0.33 & 0.32 & 0.32 & 0.34 & 0.34 & 0.26 \\
\hline & & & & & &
\end{tabular}




\begin{tabular}{cccccccc}
\hline \multicolumn{7}{c}{ Pegmatito Boanerges } & \multicolumn{4}{c}{ Zona H paragnaisse } \\
\hline SiO2 & $05 \mathrm{~g} 1$ & $05 \mathrm{~g} 2$ & $05 \mathrm{~g} 3$ & $17.2 \mathrm{ga}$ & $17.2 \mathrm{gb}$ & $17.2 \mathrm{gc}$ & $17.2 \mathrm{gd}$ \\
$\mathrm{TiO} 2$ & 37.82 & 37.62 & 36.49 & 37.40 & 37.29 & 37.60 & 37.29 \\
$\mathrm{Al} 2 \mathrm{O3}$ & 0.03 & 0.02 & 0.00 & 0.00 & 0.23 & 0.21 & 0.15 \\
$\mathrm{FeOt}$ & 20.16 & 19.95 & 19.71 & 19.81 & 19.75 & 19.30 & 19.69 \\
$\mathrm{MnO}$ & 12.64 & 15.01 & 16.51 & 19.86 & 20.87 & 19.74 & 19.57 \\
MgO & 29.82 & 27.57 & 25.69 & 9.39 & 10.37 & 10.24 & 8.86 \\
CaO & 0.06 & 0.04 & 0.06 & 0.30 & 0.31 & 0.27 & 0.28 \\
Total & 0.46 & 0.52 & 0.52 & 13.26 & 11.79 & 12.61 & 13.46 \\
\hline & 100.99 & 100.75 & 99.02 & 100.00 & 100.61 & 99.96 & 99.29 \\
\hline Si & 3.071 & 3.068 & 3.04 & 3.00 & 2.99 & 3.02 & 3.01 \\
Al iv & 0.000 & 0.000 & 0.00 & 0.00 & 0.01 & 0.00 & 0.00 \\
Al vi & 1.930 & 1.919 & 1.94 & 1.88 & 1.86 & 1.84 & 1.88 \\
Ti & 0.002 & 0.001 & 0.00 & 0.00 & 0.01 & 0.01 & 0.01 \\
Fe3+ & 0.000 & 0.010 & 0.02 & 0.11 & 0.11 & 0.12 & 0.10 \\
Fe2+ & 0.862 & 1.013 & 1.12 & 1.22 & 1.28 & 1.21 & 1.22 \\
Mn & 2.051 & 1.905 & 1.81 & 0.64 & 0.70 & 0.70 & 0.60 \\
Mg & 0.007 & 0.005 & 0.01 & 0.04 & 0.04 & 0.03 & 0.03 \\
Ca & 0.040 & 0.045 & 0.05 & 1.14 & 1.01 & 1.08 & 1.16 \\
Almandina & 27.50 & 32.41 & 36.51 & 38.99 & 40.94 & 37.81 & 38.95 \\
Andradita & 0.00 & 0.54 & 1.26 & 5.46 & 5.73 & 6.07 & 4.90 \\
Grossulária & 1.38 & 1.03 & 0.32 & 32.89 & 28.35 & 31.12 & 34.50 \\
Piropo & 0.25 & 0.17 & 0.25 & 1.20 & 1.26 & 1.11 & 1.14 \\
Espessartita & 70.87 & 65.85 & 61.66 & 21.46 & 23.71 & 23.89 & 20.51 \\
Mn/Fe & 0.70 & 0.65 & 0.62 & 0.34 & 0.35 & 0.37 & 0.33 \\
\hline
\end{tabular}


Y-POLICRÁSIO 


\begin{tabular}{|c|c|c|c|c|c|}
\hline & YP1 & YP2 & YP3 & YP4 & YP5 \\
\hline $\mathrm{Ta}_{2} \mathrm{O}_{5}$ & 10.03 & 8.51 & 9.99 & 9.36 & 8.42 \\
\hline $\mathrm{Nb}_{2} \mathrm{O}_{5}$ & 19.28 & 17.61 & 21.21 & 19.19 & 18.94 \\
\hline $\mathrm{TiO}_{2}$ & 20.76 & 19.44 & 21.14 & 22.23 & 22.05 \\
\hline $\mathrm{Fe}_{2} \mathrm{O}_{3}$ & 2.64 & 2.59 & 3.20 & 2.87 & 2.85 \\
\hline $\mathrm{MnO}$ & 0.45 & 0.07 & 0.20 & 0.51 & 0.16 \\
\hline $\mathrm{Y}_{2} \mathrm{O}_{3}$ & 10.99 & 8.73 & 11.35 & 11.15 & 11.09 \\
\hline $\mathrm{Gd}_{2} \mathrm{O}_{3}$ & 1.34 & 1.38 & 1.30 & 1.26 & 1.20 \\
\hline $\mathrm{Dy}_{2} \mathrm{O}_{3}$ & 2.79 & 2.93 & 2.98 & 2.60 & 2.61 \\
\hline $\mathrm{Er}_{2} \mathrm{O}_{3}$ & 1.55 & 1.91 & 1.88 & 1.77 & 1.53 \\
\hline $\mathrm{CaO}$ & 1.99 & 1.41 & 2.49 & 1.61 & 1.85 \\
\hline $\mathrm{ThO}_{2}$ & 5.35 & 4.12 & 3.27 & 3.60 & 3.03 \\
\hline $\mathrm{U}_{3} \mathrm{O}_{8}$ & 7.75 & 7.20 & 9.67 & 9.00 & 10.47 \\
\hline Total & 84.93 & 75.90 & 88.68 & 85.15 & 84.20 \\
\hline \multicolumn{6}{|c|}{ Fórmula calculada na base de 6 oxigênios } \\
\hline $\mathrm{Ta}$ & 0.176 & 0.166 & 0.167 & 0.162 & 0.147 \\
\hline $\mathrm{Nb}$ & 0.564 & 0.571 & 0.589 & 0.552 & 0.550 \\
\hline $\mathrm{Ti}$ & 1.010 & 1.049 & 0.977 & 1.064 & 1.065 \\
\hline $\mathrm{Fe}^{3+}$ & 0.128 & 0.140 & 0.148 & 0.137 & 0.138 \\
\hline $\mathrm{Mn}$ & 0.025 & 0.004 & 0.011 & 0.027 & 0.009 \\
\hline $\mathrm{Y}$ & 0.624 & 0.550 & 0.612 & 0.623 & 0.625 \\
\hline $\mathrm{Gd}$ & 0.105 & 0.123 & 0.107 & 0.097 & 0.098 \\
\hline Dy & 0.103 & 0.120 & 0.104 & 0.094 & 0.096 \\
\hline $\mathrm{Er}$ & 0.056 & 0.077 & 0.065 & 0.063 & 0.055 \\
\hline $\mathrm{Ca}$ & 0.138 & 0.108 & 0.163 & 0.110 & 0.127 \\
\hline Th & 0.079 & 0.067 & 0.046 & 0.052 & 0.044 \\
\hline U & 0.106 & 0.109 & 0.126 & 0.121 & 0.142 \\
\hline$\sum$ ETR & 0.264 & 0.320 & 0.276 & 0.254 & 0.249 \\
\hline$\sum$ cátions & 3.113 & 3.086 & 3.113 & 3.101 & 3.097 \\
\hline
\end{tabular}


RUTILO E ILMENORUTILO 


\begin{tabular}{|c|c|c|c|c|c|c|c|c|c|c|c|c|c|c|}
\hline & H22B_rt1 & H22B_rt2 & H22B_rt3 & H22B_rt4 & H22B_rt5 & H22B_rt6 & H22B_rt7 & H22B_rt8 & $\mathrm{H} 22 \_\mathrm{rt1}$ & $\mathrm{H} 22 \_\mathrm{rt} 2$ & H22_rt3 & $\mathrm{H} 22 \_\mathrm{rt} 4$ & $\mathrm{H} 22 \_\mathrm{rt} 5$ & H22_rt6 \\
\hline Ta2O5 & 5.5 & 4.08 & 6.03 & 5.03 & 14.21 & 14.19 & 16.21 & 13.25 & 0 & 0.45 & 0.26 & 0.23 & 0.17 & 0.03 \\
\hline $\mathrm{Nb} 2 \mathrm{O} 5$ & 4.54 & 4.53 & 5.35 & 5.98 & 16.44 & 16.64 & 16.87 & 17.61 & 3.72 & 2.41 & 3.08 & 1.25 & 2.67 & 2.70 \\
\hline $\mathrm{TiO} 2$ & 86.17 & 87.53 & 85.57 & 82.36 & 61.34 & 60.59 & 58.27 & 59.08 & 93.99 & 94.83 & 93.48 & 97.56 & 96.07 & 97.36 \\
\hline $\mathrm{Fe} 2 \mathrm{O} 3$ & 2.99 & 2.82 & 3.50 & 3.234 & 8.89 & 8.77 & 8.88 & 9.11 & 0.87 & 0.83 & 0.83 & 0.86 & 0.60 & 0.78 \\
\hline Total & 99.20 & 98.96 & 100.45 & 96.60 & 100.87 & 100.18 & 100.24 & 99.04 & 98.57 & 98.52 & 97.66 & 99.89 & 99.51 & 100.86 \\
\hline & \multicolumn{14}{|c|}{ Fórmula calculada na base de 2 oxigênios } \\
\hline $\mathrm{Ta}$ & 0.020 & 0.015 & 0.022 & 0.019 & 0.060 & 0.060 & 0.070 & 0.057 & 0.000 & 0.002 & 0.001 & 0.001 & 0.001 & 0.000 \\
\hline $\mathrm{Nb}$ & 0.028 & 0.028 & 0.033 & 0.038 & 0.115 & 0.118 & 0.121 & 0.126 & 0.022 & 0.014 & 0.018 & 0.007 & 0.016 & 0.015 \\
\hline $\mathrm{Ti}$ & 0.932 & 0.939 & 0.922 & 0.920 & 0.755 & 0.751 & 0.734 & 0.743 & 0.970 & 0.978 & 0.974 & 0.988 & 0.978 & 0.979 \\
\hline $\mathrm{Fe}$ & 0.015 & 0.014 & 0.018 & 0.017 & 0.052 & 0.052 & 0.053 & 0.054 & 0.004 & 0.004 & 0.004 & 0.004 & 0.003 & 0.004 \\
\hline
\end{tabular}


